\title{
Accident Analyses and Control Options in Support of the Sludge Water System Safety Analysis
}

Prepared for the U.S. Department of Energy

Assistant Secretary for Environmental Management

\section{Fluor Hanford}

P.O. Box 1000

Richland, Washington

Contractor for the U.S. Department of Energy

Richland Operations Office under Contract DE-AC06-96RL13200

Approved for Public Release

(Upon receipt of Clearance approval)

Further Dissemination Unlimited 


\section{Accident Analyses and Control Options in Support of the Sludge Water System Safety Analysis}

JC Williams, Fluor Hanford

November 2003

Prepared for the U.S. Department of Energy

Assistant Secretary for Environmental Management

\section{Fluor Hanford}

P.O. Box 1000

Richland, Washington

Contractor for the U.S. Department of Energy

Amis Bradex $\frac{11 / 15 / 03}{\text { Date }}$ Janis Braden

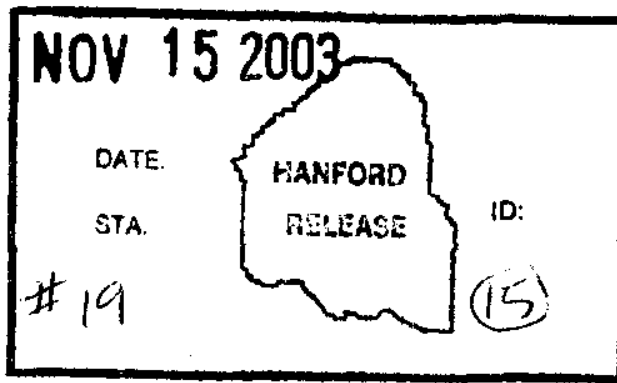

Release Approval (stamp)

Approved for Public Release

(Upon receipt of Clearance approval)

Further Dissemination Unlimited 


\begin{tabular}{|l|l|}
\hline \multicolumn{2}{|c|}{ For use with Technical Documents (when appropriate) } \\
\hline EDC- HNF-EDC-03-18834 & FMP- \\
\hline EDT- & ECN- \\
\hline Project No.: A $16 \quad(0 \mathrm{~KB} / 1 / 15 / 03)$ & Division: SNF \\
\hline Document Type: CN & Page Count: $182 \quad(0 / 131 / 15 / 03)$ \\
\hline
\end{tabular}

\begin{tabular}{|l|l|l|l|l|}
\hline \multicolumn{5}{|c|}{ For use with Speeches, Articles, or Presentations (when appropriate) } \\
\hline \multicolumn{1}{|c|}{ Abstract } & & Summary & Full Paper & Visual Aid \\
\hline Conference Name: & & & \\
\hline Conference Date: & & \\
\hline Conference Location: & & \\
\hline Conference Sponsor: & & \\
\hline Published in: & & \\
\hline Publication Date: & \\
\hline
\end{tabular}

\section{LEGAL DISCLAIMER}

This report was prepared as an account of work sponsored by an agency of the United States Government. Neither the United States Government nor any agency thereof, nor any of their employees, nor any of their contractors, subcontractors or their employees, makes any warranty, express or implied, or assumes any legal liability or responsibility for the accuracy, completeness, or any third party's use or the results of such use of any information, apparatus, product, or process disclosed, or represents that its use would not infringe privately owned rights. Reference herein to any specific commercial product, process, or service by trade name, trademark, manufacturer, or otherwise, does not necessarily constitute or imply its endorsement, recommendation, or favoring by the United States Government or any agency thereof or its contractors or subcontractors. The views and opinions of authors expressed herein do not necessarily state or reflect those of the United States Government or any agency thereof.

Scientific or technical information is available to U.S. Government and U.S. Government contractor personnel through the Office of Scientific and Technical Information (OSTI). It is available to others through the National Technical information Service (NTIS).

This report has been reproduced from the best available copy. 


\section{RECORD OF REVISION}

(1) Document Number
SNE-10272

Page 1

(2) Title

Accident Analyses and Control Options in Support of the Sludge Water System Safety Analysis

Change Control Record

(3) Revision

1

$-$

$--$

2
(4) Description of Change - Replace, Add, and Delete Pages

(7)

Initial release via EDT 618572 on August 20, 2002

EDC HNF-02-13043; Revised to incorporate the safety analyses originally documented in

SNF-10208 "Preliminary Documented Safety Analyses

for sludge water system." Changes made for

consistency with similar analyses performed in

support of Sludge Handling System (HNF-6964).

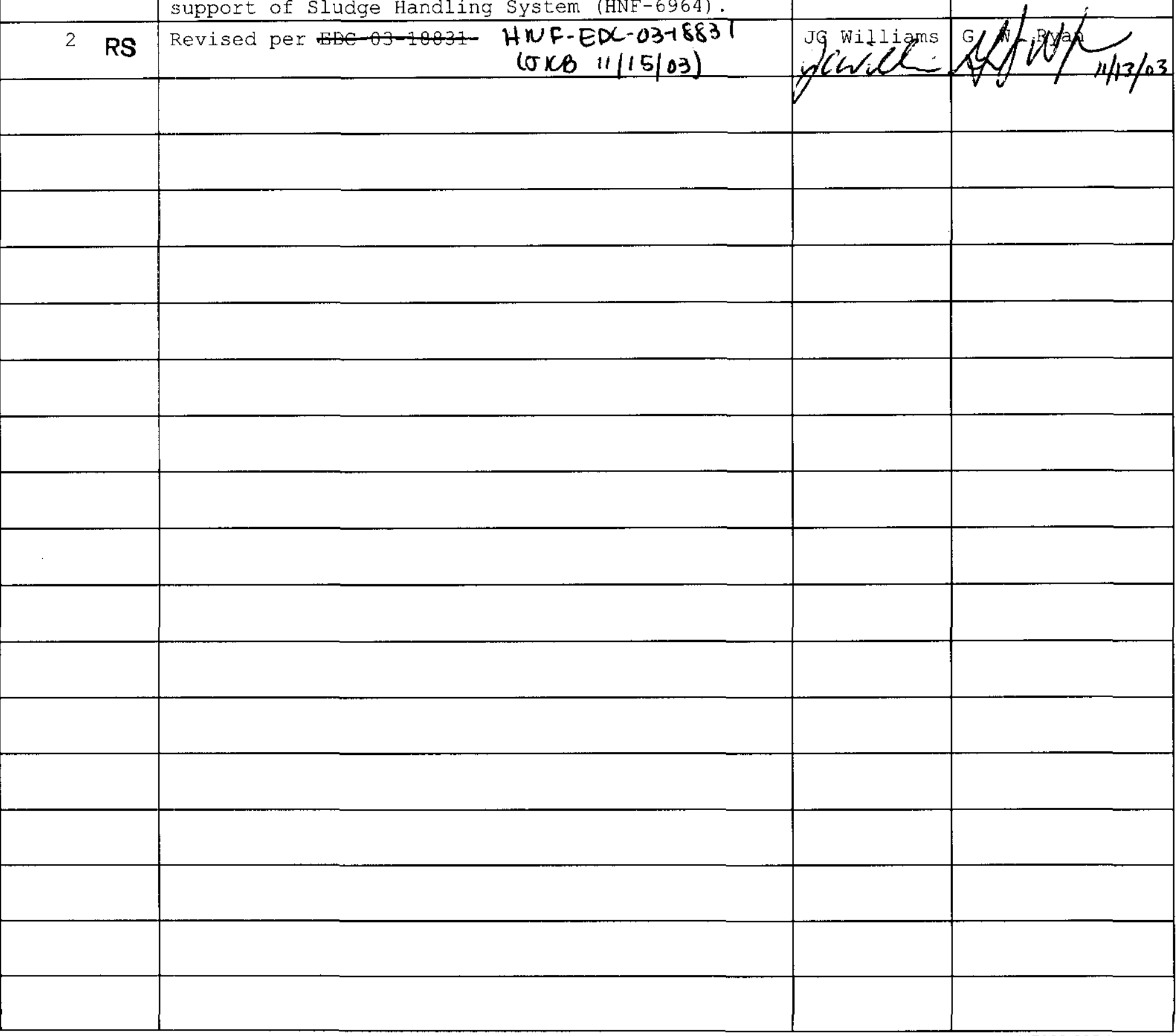

Authorized for Release

\begin{tabular}{l|ll} 
(5) Cog. Engr. & (6) Cog. Mgr. Date
\end{tabular}

JC Williams B. E. Hey

B. E. Hey G. W. Ryan 


\section{Accident Analyses and Control Options in Support of the Sludge Water System Safety Analysis}

Prepared by:

J. C. Williams, R. M. Marusich, D. A. Himes, and B. E. Hey

Fluor Hanford

Date Published

October 2003

Prepared for the U. S. Department of Energy

\section{FLUOR HANFORD}

Richland, Washington

Hanford Management and Integration Contractor for the

U.S. Department of Energy under Contract DE-AC06-96RL13200 
SNF-10272 REV. 2

This page is intentionally left blank. 
SNF-10272 REV. 2

\section{EXECUTIVE SUMMARY}

This report documents the accident analyses and nuclear safety control options for use in Revision 7 of HNF-SD-WM-SAR-062, K Basins Safety Analysis Report and Revision 4 of HNFSD-SNF-TSR-001, Technical Safety Requirements - $100 \mathrm{KE}$ and $100 \mathrm{KW}$ Fuel Storage Basins. These documents will define the authorization basis for Sludge Water System (SWS) operations. This report follows the guidance of DOE-STD-3009-94, Preparation Guide for U.S. Department of Energy Nonreactor Nuclear Facility Safety Analysis Reports, for calculating onsite and offsite consequences. The accident analysis summary is shown in Table ES-1 below.

While this document describes and discusses potential control options to either mitigate or prevent the accidents discussed herein, it should be made clear that the final control selection for any accident is determined and presented in HNF-SD-WM-SAR-062. 
Table ES-1. Sludge and Water System Accident Analysis Summary. (2 sheets)

\begin{tabular}{|c|c|c|c|c|}
\hline Section & Hazard & $\begin{array}{c}\text { Unmitigated } \\
\text { Consequences }\end{array}$ & Safety SSCs & $\begin{array}{c}\text { Technical Safety } \\
\text { Requirements }\end{array}$ \\
\hline 3.4 .1 & $\begin{array}{l}\text { Spray Release } \\
\text { from Sludge } \\
\text { Retrieval Line }\end{array}$ & $\begin{array}{l}1.9 \mathrm{E}+01 \mathrm{rem} / \\
6.4 \mathrm{E}-01 \mathrm{mg} / \mathrm{m}^{3} \text { onsite } \\
7.8 \mathrm{E}-02 \mathrm{rem} / \\
3.9 \mathrm{E}-04 \mathrm{mg} / \mathrm{m}^{3} \text { offsite }\end{array}$ & None Required & $\begin{array}{l}\text { Sludge Retrieval/Shipment } \\
\text { Prep Control AC } \\
\left.\text { - c (batch size } \leq 0.5 \mathrm{~m}^{3}\right) \\
\text { - d }(60: 40 \text { ratio) }\end{array}$ \\
\hline 3.4 .2 & Sludge Spill & $\begin{array}{l}4.4 \mathrm{E}+00 \mathrm{rem} / \\
8.1 \mathrm{E}-01 \mathrm{mg} / \mathrm{m}^{3} \text { onsite } \\
4.4 \mathrm{E}-03 \mathrm{rem} / \\
5.0 \mathrm{E}-04 \mathrm{mg} / \mathrm{m}^{3} \text { offsite }\end{array}$ & None Required & $\begin{array}{l}\text { Sludge Retrieval/Shipment } \\
\text { Prep Control AC: } \\
\left.\text { - c (batch size } \leq 0.5 \mathrm{~m}^{3}\right) \\
\text { - d ( } 60: 40 \text { ratio) }\end{array}$ \\
\hline 3.4 .3 & $\begin{array}{l}\text { High Chemical } \\
\text { Reaction Rate in } \\
\text { LDC }\end{array}$ & $\begin{array}{l}\text { See Cask and LDC } \\
\text { overpressurization }\end{array}$ & $\begin{array}{l}\text { SS Strainer basket } \\
\text { SS LDC DFs }{ }^{2} \text { : } \\
\text { - pressure boundary } \\
\text { - deflector plate }\end{array}$ & $\begin{array}{l}\text { Sludge Retrieval/Shipment } \\
\text { Prep Control AC: } \\
\text { - }(\mathrm{a}, \mathrm{b}, \mathrm{c}, \mathrm{d}, \mathrm{i}) \text { retrieval } \\
\text { - }(\mathrm{e}, \mathrm{f}, \mathrm{g}, \mathrm{h}) \text { volume/vent }\end{array}$ \\
\hline 3.4 .4 & $\begin{array}{l}\text { Cask } \\
\text { Overpressurization }\end{array}$ & $\begin{array}{l}\text { See LDC } \\
\text { overpressurization }\end{array}$ & $\begin{array}{l}\text { SS Cask: pressure } \\
\text { boundary } \\
\text { SS SWS-SRV-501 DF } \\
\text { SS Strainer basket } \\
\text { SS LDC DFs: } \\
\text { - deflector plate }\end{array}$ & $\begin{array}{l}\text { Sludge Retrieval/Shipment } \\
\text { Prep Control AC: } \\
\text { - (a, b, c, d, i) retrieval } \\
\text { - (e,f,g, h) volume/vent } \\
\text { - Maintain doors open }\end{array}$ \\
\hline 3.4 .5 & $\begin{array}{l}\text { LDC } \\
\text { Overpressurization }\end{array}$ & $\begin{array}{l}9.9 \mathrm{E}+01 \mathrm{rem} / \\
1.8 \mathrm{E}+01 \mathrm{mg} / \mathrm{m}^{3} \text { onsite } \\
1.0 \mathrm{E}-01 \mathrm{rem} / \\
1.1 \mathrm{E}-02 \mathrm{mg} / \mathrm{m}^{3} \text { offsite }\end{array}$ & $\begin{array}{l}\text { SS LDC DFs: } \\
\text { - pressure boundary } \\
\text { - deflector plate } \\
\text { - filter assembly } \\
\text { SS Strainer basket } \\
\text { SS LDC vent path } \\
\text { SRV-402 DF on SRS }\end{array}$ & $\begin{array}{l}\text { Sludge Retrieval/Shipment } \\
\text { Prep Control AC: } \\
\text { - (a, b, c, d, i) retrieval } \\
\text { - (e, f, g, h)volume/vent } \\
\text { - Maintain doors open }\end{array}$ \\
\hline 3.4 .6 & $\begin{array}{l}\text { Hydrogen Burn in } \\
\text { Cask }\end{array}$ & $\begin{array}{l}\text { See ignition of } \\
\text { hydrogen in LDC }\end{array}$ & $\begin{array}{l}\text { SS LDC DFs: } \\
\text { - deflector plate } \\
\text { SS Strainer basket } \\
\text { SS AIVS }^{3}\end{array}$ & $\begin{array}{l}\text { Sludge Retrieval/Shipment } \\
\text { Prep Control AC: } \\
\text { - }(\mathrm{a}, \mathrm{b}, \mathrm{c}, \mathrm{d}, \mathrm{i}) \text { retrieval } \\
\text { - }(\mathrm{e}, \mathrm{f}, \mathrm{g}, \mathrm{h}) \text { volume/vent } \\
\text { - }(\mathrm{j}, \mathrm{k}) \text { inerting } \\
\text { - Maintain doors open } \\
\text { AIVS LCO } 3.8\end{array}$ \\
\hline 3.4 .7 & $\begin{array}{l}\text { Hydrogen Burn in } \\
\text { LDC }\end{array}$ & $\begin{array}{l}2.1 \mathrm{E}+02 \text { rem onsite } \\
1.9 \mathrm{E}+00 \text { rem offsite }\end{array}$ & $\begin{array}{l}\text { SS LDC DFs: } \\
\text { - pressure boundary } \\
\text { - deflector plate } \\
\text { SS Strainer bsket } \\
\text { SS AIVS }\end{array}$ & $\begin{array}{l}\text { Sludge Retrieval/Shipment } \\
\text { Prep Control AC: } \\
\text { - (a, b, c, d, i) retrieval } \\
\text { - (e, f, g, h) volume/vent } \\
\text { - (j, k) inerting } \\
\text { AIVS LCO } 3.8 \\
\end{array}$ \\
\hline
\end{tabular}

\footnotetext{
inert atmosphere.

${ }^{2}$ LDC SS DFs = pressure boundary, inlet deflector plate, inner filter assembly.

${ }^{3}$ AIVS $=$ Active Inert Ventilation System
}

' Sludge Retrieval and Shipment Preparation Control AC (AC 5.9.2-7) = a. strainer basket in place, b. basin water temperature $\leq 25$ C, c. $0.5 \mathrm{~m}^{3}$ batch settling, d. $60: 40$ mixture, e. payload $\leq 2.0 \mathrm{~m}^{3}$, f. LDC void space $>1.2 \mathrm{~m}^{3}, \mathrm{~g}$. cask annulus void space $>1.2 \mathrm{~m}^{3}$, h. LDC vented, i. strainer bypass valves closed, $\mathrm{j}$. LDC inert atmosphere, $\mathrm{k}$. cask 
Table ES-1. Sludge and Water System Accident Analysis Summary. (2 sheets)

\begin{tabular}{|c|c|c|c|c|}
\hline Section & Hazard & $\begin{array}{c}\text { Unmitigated } \\
\text { Consequences }\end{array}$ & Safety SSCs & $\begin{array}{c}\text { Technical Safety } \\
\text { Requirements }\end{array}$ \\
\hline 3.4 .8 & $\begin{array}{l}\text { Fire Directly } \\
\text { Impacting Sludge } \\
\text { and Water System } \\
\text { Equipment }\end{array}$ & $\begin{array}{l}1.3 \mathrm{E}+00 \text { rem onsite } \\
1.3 \mathrm{E}-03 \text { rem offsite }\end{array}$ & SS STS Cask & $\begin{array}{l}\text { Truck/entry Controls AC } \\
\text { 5.9.2.11 } \\
\text { Fire Protection Program AC } \\
\text { 5.11.2.5 }\end{array}$ \\
\hline 3.4 .9 & $\begin{array}{l}\text { Fire Indirectly } \\
\text { Impacting Sludge } \\
\text { and Water System } \\
\text { Equipment }\end{array}$ & See heavy load drop & SS STS Cask DF & $\begin{array}{l}\text { Fire Protection Program } \mathrm{AC} \\
5.11 .2 .5\end{array}$ \\
\hline $3.4,10$ & $\begin{array}{l}\text { Heavy Load Drop } \\
\text { or Impact }\end{array}$ & $\begin{array}{l}4.8 \mathrm{E}-02 \mathrm{rem} / \\
8.9 \mathrm{E}-03 \mathrm{mg} / \mathrm{m}^{3} \text { onsite } \\
4.8 \mathrm{E}-05 \mathrm{rem} / \\
5.4 \mathrm{E}-06 \mathrm{mg} / \mathrm{m}^{3} \text { offsite } \\
\text { Loss of basin floor or } \\
\text { wall integrity }\end{array}$ & $\begin{array}{l}\text { SC PSP support stand } \\
\text { SS STS Cask DF }\end{array}$ & $\begin{array}{l}\text { Heavy Load Controls AC } \\
5.9 .2 .9\end{array}$ \\
\hline 3.4 .11 & Vehicle Impact & Not quantified & $\begin{array}{l}\text { SC Sand Filter } \\
\text { Enclosure }\end{array}$ & $\begin{array}{l}\text { Vehicle Controls AC } \\
5.9 .2 .11\end{array}$ \\
\hline 3.4 .12 & $\begin{array}{l}\text { High Radiation } \\
\text { Dose }\end{array}$ & $\begin{array}{l}2.2 \mathrm{E}+00 \mathrm{R} / \mathrm{h} \text { at } 1 \mathrm{~m} \\
\text { from plugged retrieval } \\
\text { line } \\
1.2 \mathrm{E}+00 \mathrm{R} / \mathrm{h} \text { at } 1 \mathrm{~m} \\
\text { above unshielded } \\
\text { container }\end{array}$ & None Required & $\begin{array}{l}\text { Radiation Protection } \\
\text { Program AC 5.11 }\end{array}$ \\
\hline 3.4 .13 & $\begin{array}{l}\text { Uncontrolled } \\
\text { Release of Argon }\end{array}$ & $\begin{array}{l}\text { No radiological or } \\
\text { toxicological } \\
\text { consequences. } \\
\text { Asphyxiation hazard. }\end{array}$ & $\begin{array}{l}\text { AIVS: Pressure } \\
\text { Boundary }\end{array}$ & $\begin{array}{l}\text { Hazardous Material } \\
\text { Protection Program AC } 5.11\end{array}$ \\
\hline 3.4 .14 & $\begin{array}{l}\text { Unfiltered Release } \\
\text { from LDC or } \\
\text { Cask }\end{array}$ & $\begin{array}{l}5.9 \mathrm{E}-02 \mathrm{rem} / \\
1.1 \mathrm{E}-02 \mathrm{mg} / \mathrm{m}^{3} \text { onsite } \\
5.9 \mathrm{E}-05 \mathrm{rem} / \\
6.7 \mathrm{E}-06 \mathrm{mg} / \mathrm{m}^{3} \text { offsite }\end{array}$ & None Required & None Required \\
\hline 3.4 .15 & $\begin{array}{l}\text { Loss of Electric } \\
\text { Power }\end{array}$ & Not quantified & None Required & None Required \\
\hline 3.4 .16 & $\begin{array}{l}\text { Natural } \\
\text { Phenomena } \\
\text { Hazards }\end{array}$ & $\begin{array}{l}\text { See uncontrolled argon } \\
\text { release and hydrogen } \\
\text { burn accidents }\end{array}$ & $\begin{array}{l}\text { PSP support stand } \\
\text { Bridge crane } \\
\text { K Basins structure } \\
\text { Annex structure }\end{array}$ & $\begin{array}{l}\text { None specifically credited } \\
\text { however AC 5.11 Safety } \\
\text { Programs would apply } \\
\text { (primarily EP) }\end{array}$ \\
\hline 3.4 .17 & External Hazards & Not quantified & None Required & $\begin{array}{l}\text { None specifically credited } \\
\text { however AC } 5.11 \text { Safety } \\
\text { Programs would apply } \\
\text { (primarily EP) }\end{array}$ \\
\hline 3.4 .18 & $\begin{array}{l}\text { Beyond Design } \\
\text { Basis Accidents }\end{array}$ & Not quantified & None Required & None Required \\
\hline
\end{tabular}


SNF-10272 REV. 2

This page is intentionally left blank 


\section{CONTENTS}

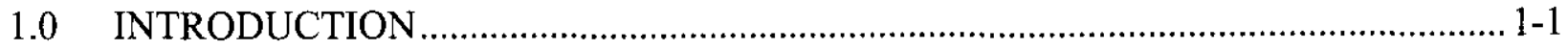

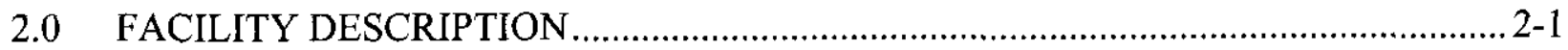

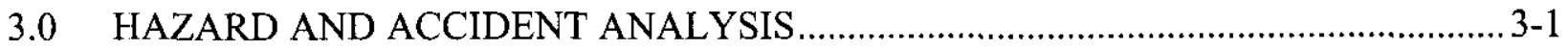

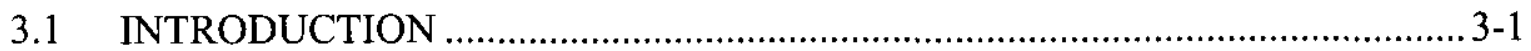

3.2 REPRESENTATIVE ACCIDENT SELECTION ……...................................... 3-1

3.3 GENERAL CONSEQUENCE METHODOLOGY ............................................ 3-1

3.3.1 ESTIMATING THE AMOUNT AIRBORNE AS RESPIRABLE

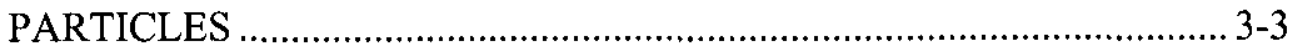

3.3.2 RADIOLOGICAL DOSE CONSEQUENCE METHOD .......................... 3-4

3.3.3 TOXICOLOGICAL DOSE CALCULATION METHOD ……................ 3-10

3.4 EVALUATION BASIS ACCIDENTS ..................................................... 3-11

3.4.1 SPRAY RELEASE FROM SLUDGE RETRIEVAL LINE …………...... 3-12

3.4.2 SLUDGE SPILL/CONTAMINATION SPREAD................................. 3-19

3.4.3 HIGH CHEMICAL REACTION RATE IN LDC ................................... 3-24

3.4.4 CASK OVERPRESSURIZATION …………................................ 3-28

3.4.5 LDC OVERPRESSURIZATION ...................................................

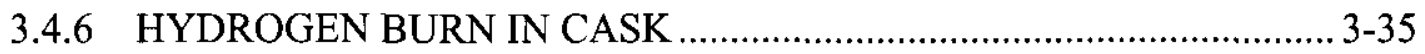

3.4.7 HYDROGEN BURN IN LDC....................................................... 3-42

3.4.8 FIRE DIRECTLY IMPACTING SLUDGE AND WATER SYSTEM

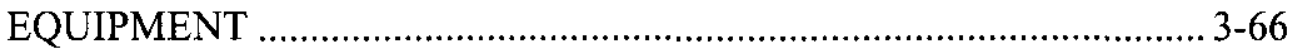

3.4.9 FIRE INDIRECTLY IMPACTING SLUDGE AND WATER SYSTEM

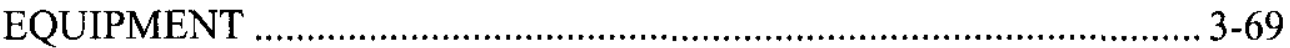

3.4.10 HEAVY LOAD DROP OR IMPACT ………................................. 3-70

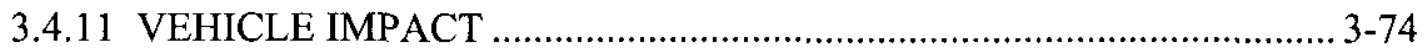

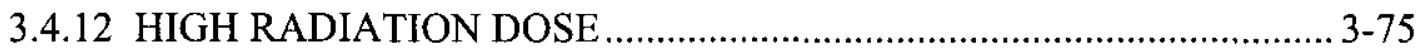

3.4.13 UNCONTROLLED RELEASE OF ARGON ……............................. 3-76

3.4.14 UNFILTERED RELEASE FROM LDC OR CASK ................................ 3-77

3.4.15 LOSS OF ELECTRICAL POWER …………..................................... 3-79

3.4.16 NATURAL PHENOMENA HAZARDS ……................................. 3-79

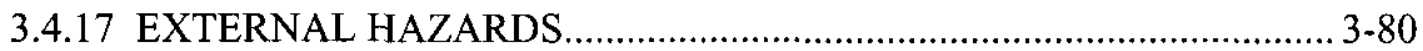

3.4.18 BEYOND DESIGN BASIS ACCIDENTS ……................................ 3-80

3.5 ACCIDENT FREQUENCY ASSESSMENT ………................................. 3-80

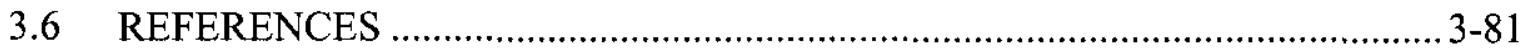

APPENDIX A - SPRAY CODE OUTPUT FOR SRS SPRAY RELEASE ………................. A-1

APPENDIX B - FINAL PRESSURE IN THE LDC DUE TO HYDROGEN BURNS .............. B-1

APPENDIX C - LDC BURST PRESSURE AND MINIMUM VOID VOLUME ..................... C-1

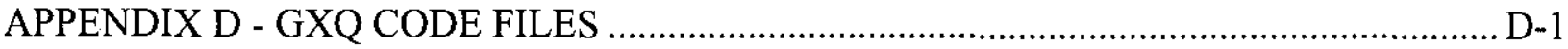

APPENDIX E - MICROSHIELD OUTPUT ………………............................................

APPENDIX F - PEER REVIEW CHECKLISTS............................................................. 


\section{LIST OF TABLES}

Table 3-1. Crosswalk Between Hazard Bins And Representative Accidents............................. 3-2

Table 3-2. Atmospheric Transport Factors Used In Accident Analyses For K Basins. .............. 3-6

Table 3-3. Isotopic Composition Of K East Basin Sludge. ....................................................... 3-8

Table 3-4. Fifty-Year Committed Effective Dose Equivalent Per Unit Respirable Milliliter Or Gram Of 60:40 Volume Percent Ratio Of Floor To Canister Sludge Mixture Inhaled.

Table 3-5. Accident Consequence Classification .......................................................... 3-10

Table 3-6. Radiological Evaluation Guidelines. .............................................................. 3-10

Table 3-7. Grams Uranium In 1 L Safety Basis 60:40 Ke Basin Sludge.................................. 3-11

Table 3-8. Airborne Release Fraction For Different Crack Widths......................................... 3-15

Table 3-9. Summary Of Maximum Dose Consequences For Unmitigated Pressurized

Aerosol Release (Blocked Discharge And 0.3 Mm Slit Opening)..................... 3-15

Table 3-10. Downwind Uranium Concentration For Unmitigated Pressurized Aerosol Release

(Blocked Discharge And 0.3 Mm Slit Opening)............................................ 3-16

Table 3-11. Summary Of Maximum Dose Consequences For Pressurized Aerosol Release Mitigated By Spray Shields........................................................................ 3-17

Table 3-12. Downwind Uranium Concentration For Pressurized Aerosol Release Mitigated By Spray Shields................................................................................... 3-17

Table 3-13. Summary Of Maximum Dose Consequences For Pressurized Aerosol Release Mitigated By Open Discharge Into The LDC. .............................................. 3-18

Table 3-14. Downwind Uranium Concentration For Pressurized Aerosol Release Mitigated By Open Discharge Into The LDC. ................................................................ 3-18

Table 3-15. Summary Of Dose Consequences For Splash/Splatter Of 500-L Sludge Spill..... 3-21

Table 3-16. Downwind Uranium Concentration For Splash/Splatter Of 500-L Sludge Spill. . 3-22

Table 3-17. Summary Of Dose Consequences For Splash/Splatter Of 1-L Sludge Spill......... 3-22

Table 3-18. Summary Of Dose Consequences For Resuspension Of 1-L Sludge Spill............ 3-23

Table 3-19. Summary Of Total Dose Consequences For 1-L Sludge Spill.............................. 3-23

Table 3-20. Downwind Uranium Concentration For 1-L Sludge Spill. .................................... 3-23

Table 3-21. Summary Of Maximum Dose Consequences For LDC Overpressurization.......... 3-33

Table 3-22. Downwind Uranium Concentration For LDC Overpressurization. ...................... 3-33

Table 3-23a. Summary Of Maximum Dose Consequences For Hydrogen Burn In Cask........ 3-38

Table 3-23b. Dose Consequences For Hydrogen Burn In Cask ............................................... 3-39

Table 3-24. Summary Of Maximum Dose Consequences For Hydrogen Burn In Cask.......... 3-39

Table 3-25. Hydrogen Burn In Sludge Transportation Cask Summary Table. ......................... 3-41

Table 3-26. Hydrogen Burn Parameters ............................................................................ 3-45

Table 3-27. Hydrogen Burn Source Term Summary ………............................................. 3-57

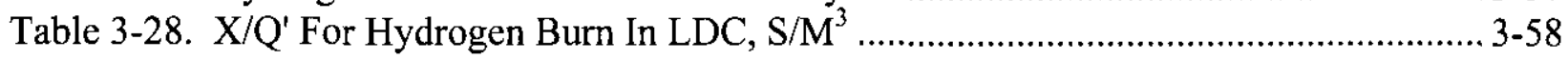

Table 3-29a. Dose Consequences For Hydrogen Burn Within LDC........................................ 3-59

Table 3-29b. Dose Consequences For Hydrogen Burn Within LDC …….............................. 3-59

Table 3-30. Dose Consequences For Hydrogen Burn Within LDC ${ }^{1}$.......................................... 3-60

Table 3-31. Dose Consequences Of A Deflagration Or Partial Decant..................................... 3-60

Table 3-32. Hydrogen Burn Consequence Summary ........................................................... 3-62

Table 3-33. Unmitigated Accident Summary Table ............................................................... 3-62 
Table 3-34. Summary Of Maximum Dose Consequences For Unmitigated Fire Engulfing Shipping Cask.....

Table 3-35. Comparative Aerosol Loadings................................................................. 3-73

Table 3-36. Summary Of Maximum Dose Consequences For Unmitigated Heavy Load Drop Onto LDC. 3-73

Table 3-37. Downwind Uranium Concentration For Unmitigated Heavy Load Drop Onto LDC.3-74

Table 3-38. Predicted Doses At Three Different Positions Relative To The Pipe And Using Three Different Dilution Factors.

Table 3-39. Predicted Doses At Three Heights Above The Top Of The LDC......................... 3-76

Table 3-40. Summary Of Maximum Dose Consequences For Unmitigated Unfiltered Release

From LDC Or Cask. 3-78

Table 3-41. Downwind Uranium Concentration For Unmitigated Unfiltered Release From LDC

Or Cask. 3-78 
SNF-10272 REV. 2

$\mathrm{AC}$

AED

AIVS

ALARA

ARF

ARR

ASME

BR

DBE

DCF

DF

DOE

DR

ERPG

FM

FTS

HEPA

IXC

IXM

$\mathrm{KE}$

KW

LDC

LFL

LPF

MAR

MOI

NA

NEC

NRC

PRV

PSAA

RF

$\mathrm{SC}$

SNF

SPR

SS

SRS

SSC

SWS

TEEL.

TNT

TSR

TWA

UD

UFL

\section{LIST OF TERMS}

administrative control

aerodynamic equivalent diameter

active inert ventilation system

as low as reasonably achievable

airborne release fraction

airborne release rate

American Society of Mechanical Engineers

breathing rate

design basis earthquake

dose conversion factor

design feature

U.S. Department of Energy

damage ratio

emergency response planning guidelines

factory mutual global

Fuel Transfer System

high-efficiency particulate air

ion exchange column

ion exchange module

$\mathrm{K}$ East

K West

large-diameter container

lower flammability limit

leak path factor

material at risk

maximum offsite individual

not applicable

National Electrical Code

U.S. Nuclear Regulatory Commission

pressure relief valve

Package Safety Analysis Assessment

respirable fraction

safety class

spent nuclear fuel

second pressure reducer

safety significant

Sludge Retrieval System

structure, system, and component

Sludge and Water System

temporary emergency exposure limit

trinitrotoluene

technical safety requirement

time-weighted average

unit dose

upper flammability limit 
SNF-10272 REV. 2

\section{1:0 INTRODUCTION}

This report documents the accident analyses and nuclear safety control options for use in Revision 7 of HNF-SD-WM-SAR-062, K Basins Safety Analysis Report and Revision 4 of HNF-SD-SNF-TSR-001, Technical Safety Requirements - $100 \mathrm{KE}$ and $100 \mathrm{KW}$ Fuel Storage Basins. These documents will define the authorization basis for Sludge Water System (SWS) operations.

While this document describes and discusses potential control options to either mitigate or prevent the accidents discussed herein, it should be made clear that the final control selection for any accident is determined and presented in HNF-SD-WM-SAR-062. 
SNF-10272 REV. 2

This page is intentionally left blank. 
SNF-10272 REV. 2

\subsection{FACILITY DESCRIPTION}

The SWS as analyzed here was previously described in SNF-10208, Sludge and Water System Preliminary Documented Safety Analysis, and SNF-8166, Functional Design Criteria, K East Basin Sludge and Water System, Subproject A-16. 
SNF-10272 REV. 2

This page is intentionally left blank. 


\subsection{HAZARD AND ACCIDENT ANALYSIS}

\subsection{INTRODUCTION}

A hazards analysis was initiated for the SWS in July 2001 (SNF-8626, K Basin Sludge and Water System Preliminary Hazard Analysis) and updated in December 2001 (SNF-10020, Rev. 0, Hazard Evaluation for KE Sludge and Water System - Project A16) based on conceptual design information for the Sludge Retrieval System (SRS) and $60 \%$ design information for the cask and LDC. SNF-10020 was revised in September 2003 to evaluate the as-built condition of the system.

The hazards identification process documented in the above referenced reports utilized standard industrial safety techniques (AIChE 1992, Guidelines for Hazard Evaluation Procedures) to systematically guide several interdisciplinary teams through the system using a pre-established set of process parameters (e.g., flow, temperature, pressure) and guide words (e.g., high, low, more, less). The teams generally included representation from the U.S. Department of Energy (DOE), K Basins Nuclear Safety, T Plant Nuclear Safety, K Basin Industrial Safety, fire protection, project engineering, operations, and facility engineering.

\subsection{REPRESENTATIVE ACCIDENT SELECTION}

SNF-10020 identified 559 potentially hazardous conditions associated with sludge retrieval activities. Potential accidents with unprevented or unmitigated consequences having impacts to the maximally exposed onsite or offsite individual, regardless of frequency, were candidates from which the design basis accidents were selected. The 559 hazards were grouped into 18 hazard bins. Table $3-1$ provides a crosswalk between the 18 hazard bins and the 18 representative accidents to quantify the potential nuclear safety consequences. There is not a one-to-one correspondence between the 18 hazard bins and the 18 representative accidents because some hazard bins required more than one representative accident and other hazard bins required none. Each representative accident is discussed in a subsection of this chapter. A criticality accident has been shown to be an incredible event in HNF-8513, CSER 01-002: Criticality Safety Evaluation Report for Loading, Transport, and Storage of K Basin Sludge Containers, therefore it is not included as a candidate for a design basis accident.

\subsection{GENERAL CONSEQUENCE METHODOLOGY}

Radiological consequences are estimated using standardized factors to account for the source term, atmospheric transport factor, and the unit dose. These equations and factors are discussed in more detail in the following sections. 
Table 3-1. Crosswalk Between Hazard Bins and Representative Accidents.

\begin{tabular}{|c|c|c|c|}
\hline \multicolumn{2}{|r|}{ Hazard bin } & \multirow{2}{*}{\begin{tabular}{|l} 
Representative accident \\
Spray release from sludge retrieval line \\
\end{tabular}} & \multirow{2}{*}{$\begin{array}{l}\begin{array}{l}\text { Accident } \\
\text { discussion }\end{array} \\
\text { Section } 3.4 .1\end{array}$} \\
\hline 1 & Pressurized aerosol release & & \\
\hline 7 & $\begin{array}{l}\text { Sludge Spill (low pressure } \\
\text { release) }\end{array}$ & \multirow[t]{2}{*}{ Sludge Spill } & \multirow[t]{2}{*}{ Section 3.4 .2} \\
\hline 9 & Spread of contamination & & \\
\hline 3 & High sludge temperature & High chemical reaction rate in LDC & Section 3.4 .3 \\
\hline \multirow[t]{2}{*}{2} & \multirow{2}{*}{$\begin{array}{l}\text { Overpressurized LDC or } \\
\text { cask }\end{array}$} & Cask overpressurization & Section 3.4.4 \\
\hline & & LDC overpressurization & Section 3.4.5 \\
\hline \multirow[t]{2}{*}{4} & \multirow[t]{2}{*}{ Hydrogen Burn } & Hydrogen burn in cask & Section 3.4.6 \\
\hline & & Hydrogen burn in LDC & Section 3.4 .7 \\
\hline \multirow[t]{2}{*}{5} & \multirow[t]{2}{*}{ Fire } & Fire directly impacting Sludge and Water System equipment & Section 3.4.8 \\
\hline & & Fire indirectly impacting Sludge and Water System equipment & Section 3.4 .9 \\
\hline 6 & Load drop or impact & Heavy load drop or impact & Section 3.4 .10 \\
\hline 17 & Vehicle impacts & Vehicle impact & Section 3.4 .11 \\
\hline 8 & High radiation dose & High radiation dose & Section 3.4 .12 \\
\hline 12 & $\begin{array}{l}\text { Argon rupture/uncontrolled } \\
\text { release of argon }\end{array}$ & Argon release & Section 3.4 .13 \\
\hline 14 & $\begin{array}{l}\text { Unfiltered release from } \\
\text { LDC or cask }\end{array}$ & Unfiltered release from LDC or cask & Section 3.4 .14 \\
\hline 15 & Loss of electrical power & Loss of electrical power & Section 3.4 .15 \\
\hline \multirow[t]{2}{*}{16} & \multirow{2}{*}{$\begin{array}{l}\text { Review of natural } \\
\text { phenomena hazards and } \\
\text { beyond design basis } \\
\text { accidents for SWS }\end{array}$} & Natural phenomena hazards & Section 3.4 .16 \\
\hline & & Beyond design basis accidents & Section 3.4 .18 \\
\hline 18 & External hazards & External events & Section 3.4 .17 \\
\hline 10 & Design issues & $\begin{array}{l}\text { This bin serves as a place holder for design issues identified } \\
\text { during the hazards analysis. These issues may or may not be } \\
\text { rebinned during design refinement. These accidents were not } \\
\text { considered during the control selection/allocation process. }\end{array}$ & None \\
\hline 11 & Standard industrial hazards & $\begin{array}{l}\text { This bin collects standard industrial hazards identified during } \\
\text { the hazards analysis. These hazards are covered by existing } \\
\text { Industrial Safety and Health programs and do not require } \\
\text { further quantitative analysis. These accidents were not } \\
\text { considered during the control selection/allocation process. }\end{array}$ & None \\
\hline 13 & Negligible risks & $\begin{array}{l}\text { The } 70 \text { hazards binned under this heading have been } \\
\text { qualitatively judged to have low consequences outside the } \\
\text { facility boundary and to have no benefit from further } \\
\text { quantitative accident analyses. However it is expected that } \\
\text { both programmatic and occupational safety controls will } \\
\text { address these hazards. These accidents were not considered } \\
\text { during the control selection/allocation process. }\end{array}$ & None \\
\hline
\end{tabular}




\subsubsection{Estimating the Amount Airborne as Respirable Particles}

The airborne source term is typically estimated via the following five-component linear equation.

$$
\mathrm{Q}=\mathrm{MAR} \times \mathrm{DR} \times \mathrm{ARF} \times \mathrm{RF} \times \mathrm{LPF}
$$

where

$$
\begin{aligned}
& \mathrm{Q}=\text { quantity released as respirable particles (source term) } \\
& \mathrm{MAR}=\text { material at risk } \\
& \mathrm{DR}=\text { damage ratio } \\
& \mathrm{ARF}=\text { airborne release fraction } \\
& \mathrm{RF}=\text { respirable fraction } \\
& \mathrm{LPF}=\text { leak path factor. }
\end{aligned}
$$

The factors are described in more detail in the following sections.

\subsubsection{Source Term}

The source term, "Q," as treated in this report is the equivalent volume in liters or grams of respirable sludge aerosol released to the environment.

The release duration and the exposure duration are related terms, but there are notable differences. The release duration is the period over which the majority of the release occurs. The exposure duration is the time that the individual downwind is exposed to the hazardous material in the air. Normally the exposure duration is larger than the release duration due to the spread of the plume in the direction of travel. The exposure duration is addressed by the evaluation guidelines.

Radiological doses depend on the time-integral of the air concentration at the receptor location. For consistency with HNF-SD-WM-SAR-062, K Basins Safety Analysis Report, exposure to the entire plume passage for the maximally exposed individual onsite is assumed to be up to, but not exceeding, a 12-hour period. For receptor locations representing the Hanford Site boundary, a maximum 24-hour exposure period is assumed.

\subsubsection{Material at Risk}

The material at risk (MAR) is the volume or mass of sludge material available to be acted on by a given physical stress. For the SNF Project, the MAR is taken to be the maximum quantity of radioactive material present or reasonably anticipated at each accident location.

\subsubsection{Damage Ratio}

The damage ratio (DR) is the fraction of the MAR actually impacted by the accident-generated conditions. The DR is estimated based upon engineering analysis of the response of structural materials and materials-of-construction for containment to the type and level of stress or force generated by the event. Standard engineering approximations typically are used. These approximations often include a degree of conservatism due to simplification of phenomena to 
obtain a useable model, but the purpose of the approximation is to obtain, to the degree possible, a realistic understanding of potential effects.

\subsubsection{Airborne Release Fraction or Airborne Release Rate}

The airborne release fraction (ARF) and airborne release rate (ARR) are used to estimate the amount of radioactive material suspended in air as an aerosol and available for transport due to a physical stress from a specific accident. For discrete events, the ARF is a fraction of the material affected. For ongoing events, the ARR is a fraction of the material affected per unit time.

The ARF and ARR values used in the analyses in this chapter are taken primarily from DOE-HDBK-3010-94, Airborne Release Fractions/Rates and Respirable Fractions for Nonreactor Nuclear Facilities. The values in DOE-HDBK-3010-94 are based primarily upon experimentally measured values for specific materials (e.g., plutonium, uranium, mixed fission products) or surrogates subjected to the particular type of stress under controlled conditions. Attention is given to the parameters, if known, that may have a significant influence upon suspension by the specific mechanism and the uncertainty in the measurement as indicated by the variability of the results. It is important to note that the experiments discussed in DOE-HDBK-3010-94 evaluate release phenomena holistically. No attempt is made to precisely characterize total airborne material in terms of individual mechanisms acting within an overall given release.

\subsubsection{Respirable Fraction}

The respirable fraction $(\mathrm{RF})$ is the fraction of airborne material that can be transported through the air and inhaled into the human respiratory system. It is commonly assumed to include particles $10 \mu \mathrm{m}$ aerodynamic equivalent diameter (AED) and less. The term "10 $\mu \mathrm{m}$ AED" means the particle has the same settling speed in air as a unit-density sphere with a diameter of $10 \mu \mathrm{m}$. The actual diameter could differ from $10 \mu \mathrm{m}$ due to differences in density or shape. The principal emphasis in this document is directed toward the potential downwind hazard to populations at some distance from the point of source term generation.

\subsubsection{Leak Path Factor}

The leak path factor (LPF) is the fraction of the radionuclides in the aerosol transported through an engineered device used to deplete or filter particles. When evaluating the consequences of an unmitigated event, the LPF is taken to be one. The LPF is a calculated or standard value based upon (1) established relationships among size of the particulate material, airborne transport mechanisms, and losses by deposition mechanisms, or (2) specified filtration efficiencies. Depletion occurring through natural unavoidable means as part of the release phenomena can be credited in an unmitigated analysis.

\subsubsection{Radiological Dose Consequence Method}

The total onsite dose can include inhalation and submersion (i.e., immersion in the cloud of radioactive material). The total offsite dose is from the inhalation pathway. Dose is calculated using the following equation. 


$$
\mathrm{D}=\mathrm{Q} \times \chi / \mathrm{Q}^{\prime} \times \mathrm{BR} \times \mathrm{UD}
$$

where

$$
\begin{aligned}
& \mathrm{D}=50 \text {-year committed effective dose equivalent }(\mathrm{rem}) \\
& \mathrm{Q}=\text { amount released as respirable particles (source term }[\mathrm{L} \text { or } \mathrm{g}] \text { ) } \\
& \chi / \mathrm{Q}^{\prime}=\text { air transport factor }\left(\mathrm{s} / \mathrm{m}^{3}\right) \\
& \mathrm{BR}=\text { breathing rate }\left(\mathrm{m}^{3} / \mathrm{s}\right) \\
& \mathrm{UD}=\text { unit dose }(\mathrm{rem} / \mathrm{mL} \text { or } \mathrm{rem} / \mathrm{g}) .
\end{aligned}
$$

The specific value of each parameter is determined in the individual design basis accident analysis based on the physical phenomena of the accident; thus, the values are specific to the K Basins.

\subsubsection{Calculated Dose}

The calculated dose, "D," is the dose received by an individual downwind of the accident. The airborne pathway is of primary interest for the SNF Project. DOE-STD-1027-92, Hazard Categorization and Accident Analysis Techniques for Compliance with DOE Order 5480.23, Nuclear Safety Analysis Reports, quotes observations in NUREG-1140, A Regulatory Analysis on Emergency Preparedness for Fuel Cycle and Other Radioactive Material Licensees, to the effect that "for all materials of greatest interest for fuel cycle and other radioactive material licenses, the dose from the inhalation pathway will dominate the (overall) dose."

\subsubsection{Source Term}

The source term, "Q," is the amount of radioactive material released to the environment. For the purposes of this analysis when sludge is the hazardous material of concern, the release quantity is defined in terms of "as-settled" sludge because that is how the sludge is characterized. HNF-SD-SNF-TI-009, 105-K Basin Material Design Basis Feed Description for Spent Nuclear Fuel Project Facilities, Volume 2, Sludge, defines "as-settled" sludge as sludge that has had at least 3 days settling time. This is a practical laboratory definition that allows analysis and publication of data for sludge samples. The physical characteristics of "as-settled" sludge are defined in HNF-SD-SNF-TI-009, Volume 2, HNF-SD-SNF-TI-015, Spent Nuclear Fuel Project Technical Databook, Volume 2, Sludge, and SNF-7765, Supporting Basis for Spent Nuclear Fuel Project Sludge Technical Databook. The source term will be calculated as either a unit of mass (grams) or volume (liters).

\subsubsection{Air Transport Factor}

The air transport factor, $\chi / Q^{\prime}$, gives the air concentration at the receptor location per unit release rate of material. For consistency with HNF-SD-WM-SAR-062, 99.5-percentile maximum sector atmospheric transport factors are used as shown in Table 3-2. These atmospheric transport factors were calculated using the GXQ 4.0B computer code documented in WHC-SD-GN-SWD-30002, GXQ 4.0 Program Users' Guide, and WHC-SD-GN-SWD-30003, $G X Q 4.0$ Program Verification and Validation, and were based on specific release assumptions in the accidents described in later sections. Version 4.0F was used for certain $\chi / Q^{\prime}$ s in Sections 3.4.6 and 3.4.7. 
Table 3-2. Atmospheric Transport Factors Used in Accident Analyses for K Basins.

\begin{tabular}{|c|c|c|c|c|c|}
\hline \multirow{3}{*}{$\begin{array}{l}\text { Receptor location } \\
\text { description }\end{array}$} & \multicolumn{5}{|c|}{ Atmospheric transport factors for various release durations $\left(\mathrm{s} / \mathrm{m}^{3}\right)^{\mathrm{a}}$} \\
\hline & \multirow{2}{*}{$\begin{array}{c}\text { Acute } \\
\begin{array}{c}\text { Less thing } \\
1 \text { hour }\end{array}\end{array}$} & \multirow{2}{*}{$\begin{array}{l}\text { Meander } \\
1 \text { to } 2 \text { hours }^{d}\end{array}$} & \multicolumn{2}{|c|}{ Logarithmic interpolation $^{b}$} & \multirow{2}{*}{$\underbrace{\text { Chronic }}_{\text {Annual }}$} \\
\hline & & & 12 hours $^{e}$ & 24 hours $^{\mathrm{e}}$ & \\
\hline $\begin{array}{l}\text { Onsite } \\
(100 \mathrm{~m}, \mathrm{E})\end{array}$ & $7.32 \mathrm{E}-02$ & $1.24 \mathrm{E}-02$ & $6.28 \mathrm{E}-03$ & NA & $5.12 \mathrm{E}-04$ \\
\hline $\begin{array}{l}\text { Columbia River, near bank } \\
(520 \mathrm{~m}, \mathrm{~W})\end{array}$ & $3.55 \mathrm{E}-03$ & $6.17 \mathrm{E}-04$ & $2.90 \mathrm{E}-04$ & NA & 1.79 E-05 \\
\hline $\begin{array}{l}100 \text { Area Fire Station } \\
(3,750 \mathrm{~m}, \text { ESE })\end{array}$ & $1.60 \mathrm{E}-04$ & $7.82 \mathrm{E}-05$ & $2.73 \mathrm{E}-05$ & NA & $5.70 \mathrm{E}-07$ \\
\hline $\begin{array}{l}\text { Hanford Site boundary } \\
(10,070 \mathrm{~m}, \mathrm{~W})\end{array}$ & $4.49 \mathrm{E}-05$ & 3.12 E-05 & $1.01 \mathrm{E}-05$ & $6.51 \mathrm{E}-06$ & $1.58 \mathrm{E}-07$ \\
\hline
\end{tabular}

${ }^{a}$ All teleases (except hydrogen detonation) are assumed to be point sources at ground level to maximize the dose consequences.

${ }^{\mathrm{b}}$ Atmospheric transport factors are computed by logarithmic interpolation between the 1-hour to 2-hour value and the annual average value.

No adjustment for plume meander.

${ }^{\mathrm{d}}$ Plume meander adjustment used is found in U.S. Nuclear Regulatory Commission Regulatory Guide 1.145, 1982, Atmospheric Dispersion Models for Potential Accident Consequence Assessments at Nuclear Power Plants, U.S. Nuclear Regulatory Commission, Washington, D.C.

'The 12-hour durations are used for onsite exposures and the 24-hour durations are used for offsite exposures (see HNF-SD-SNF-TI-059, 1999, A Discussion on the Methodology for Calculating Radiological and Toxicological Consequences for the Spent Nuclear Fuel Project at the Hanford Site, Rev. 2, Fluor Daniel Hanford, Inc., Richland, Washington). These are bounding exposure times.

$\mathrm{NA}=$ not applicable.

Radiological inhalation dose consequences are calculated for four receptor locations:

- Collocated worker at $100 \mathrm{~m}$ ( $328 \mathrm{ft})$ - Evaluation guidelines defined; used for calculation of onsite doses and selection of safety-significant features

- Near bank of the Columbia River (onsite at a distance of approximately $520 \mathrm{~m}$ $[1,710 \mathrm{ft}])$ - No release limits or evaluation guidelines defined; doses calculated for the purpose of identifying any additional measures considered necessary to reduce the dose to individuals at this receptor location

- 100 Area Fire Station (onsite at a distance of approximately 3,750 m [12,300 ft]) No release limits or evaluation guidelines defined; doses calculated for the purpose of identifying any additional measures considered necessary to reduce the dose to individuals at this receptor location

- Hanford Site boundary $(10,070 \mathrm{~m}[33,000 \mathrm{ft}])$ - Release limits defined; used for calculation of offsite doses and selection of safety features.

The receptor at the Hanford Site boundary is also known as the Maximum Offsite Individual (MOI). 
The atmospheric transport factor, $\chi / Q^{\prime}$, is based on specific release conditions (e.g., ground level or elevated, long or short duration) and the receptor's distance from the release. While the methodology is common to the SNF Project, the atmospheric transport factor is the timeintegrated normalized air concentration at the receptor's location, which is a measured distance from the K Basins. The atmospheric transport factor accounts for the dilution of an airborne contaminant caused by atmospheric mixing and turbulence. Table 3-2 contains the air transport values used to determine onsite and offsite consequences. Atmospheric transport factors were calculated using the methodology of U.S. Nuclear Regulatory Commission (NRC) Regulatory Guide 1.145, Atmospheric Dispersion Models for Potential Accident Consequence Assessments at Nuclear Power Plants.

Exposures to the collocated worker onsite are evaluated for the individual at the 100-m location. Evaluations at the 100 Area Fire Station and the near bank of the Columbia River are included in order to identify any additional measures considered necessary to reduce the risk to individuals at those locations. Exposures at the maximum Site boundary are used for determination of safetyclass controls.

Two of the accidents analyzed in this document adjust the atmospheric transport factors for the finite size of the source (e.g., building wake effects). Building wake and initial plume effect were included for the hydrogen burn accidents described in Sections 3.4.6 and 3.4.7. It is conservative to ignore building wake effect because this effect serves to disperse the release such that the collocated worker and the offsite receptor receive a lower estimated dose if the effect is included.

\subsubsection{Breathing Rate}

The breathing rate (BR) is the rate at which people inhale the contaminated air. The lightactivity breathing rate for an adult male is $3.33 \times 10^{-4} \mathrm{~m}^{3} / \mathrm{s}$ according to ICRP-66, Human Respiratory Tract Model for Radiological Protection. This BR is used to calculate both onsite and offsite receptor inhalation doses for all release scenarios. The adult male inhalation rate is chosen to maximize the intake and the resulting dose equivalent.

\subsubsection{Unit Dose}

The unit dose (UD) is the 50-year committed effective dose equivalent for relevant exposure pathways per gram of irradiated material inhaled. The major radiation exposure pathway for the identified accidents is inhalation of radioactive material. The UD for the sludge is computed using the methodology from HNF-SD-SNF-TI-059, A Discussion on the Methodology for Calculating Radiological and Toxicological Consequences for the Spent Nuclear Fuel Project at the Hanford Site, and can be modeled as the sum of the products of the activity and the inhalation dose factor as shown in the equation below.

$$
\mathrm{UD}=3.7 \times 10^{4} \sum_{\mathrm{K}} \frac{\mathrm{C}_{\mathrm{K}}}{\mathrm{D}} \mathrm{DCF} \mathrm{K}
$$


where

UD $=50$-year committed effective dose equivalent for inhalation of a unit mass of sludge as respirable particles, rem/g

$3.7 \times 10^{4}=\quad$ conversion factor $=\left(\frac{3.7 \times 10^{10} \mathrm{~Bq}}{1.0 \mathrm{Ci}}\right)\left(\frac{1.0 \mathrm{~m}^{3}}{1,000 \mathrm{~L}}\right)\left(\frac{1.0 \mathrm{~kg}}{1,000 \mathrm{~g}}\right)$

$\mathrm{C}_{\mathrm{K}}=$ concentration of the Kth nuclide in the sludge, $\mathrm{Ci} / \mathrm{m}^{3}$

$\mathrm{D}=$ sludge density, $\mathrm{kg} / \mathrm{L}$

$\mathrm{DCF}_{\mathrm{K}}=50$-year committed effective dose equivalent per unit activity inhaled of the Kth nuclide, rem/Bq.

Based on the analysis in SNF-10293, Evaluation of KE Basin Sludge Radioisotopics and Volumes in Support of the Sludge and Water System Safety Analysis, the sludge can be conservatively represented as a $60: 40 \mathrm{vol} \%$ mixture of floor sludge and canister sludge. The isotopic composition of the sludge is taken from Table 4-16 of HNF-SD-SNF-TI-015, Volume 2, for floor sludge and from Table 4-15 of HNF-SD-SNF-TI-015, Volume 2, for canister sludge. The values represent a conservative fit to the characterization data. The composition is presented in Table 3-3 below. Sludge densities are found in Table 4-1 of HNF-SD-SNF-TI-015, Volume 2, and represent the safety basis values. The densities are $1.5 \mathrm{~g} / \mathrm{mL}$ for floor sludge and $2.5 \mathrm{~g} / \mathrm{mL}$ for canister sludge. The density for a $60: 40$ mixture is then $1.9 \mathrm{~g} / \mathrm{mL}$.

Table 3-3. Isotopic Composition of K East Basin Sludge.

\begin{tabular}{|l|c|c|}
\hline \multirow{2}{*}{ Nuclide } & \multicolumn{2}{|c|}{ Concentration $\left(\mathbf{C i} / \mathbf{m}^{3}\right)$} \\
\cline { 2 - 3 } & Canister & Floor \\
\hline Co-60 & $4.11 \mathrm{E}+00$ & $3.80 \mathrm{E}+00$ \\
\hline Sr-90 & $1.05 \mathrm{E}+04$ & $3.04 \mathrm{E}+03$ \\
\hline Y-90 & $1.05 \mathrm{E}+04$ & $3.04 \mathrm{E}+03$ \\
\hline Tc-99 & $6.03 \mathrm{E}+01$ & NA \\
\hline Cs-137 & $3.62 \mathrm{E}+03$ & $2.60 \mathrm{E}+03$ \\
\hline Eu-154 & $5.76 \mathrm{E}+01$ & $8.70 \mathrm{E}+00$ \\
\hline Eu-155 & $5.84 \mathrm{E}+01$ & $6.17 \mathrm{E}+00$ \\
\hline U-234 & $1.59 \mathrm{E}+00$ & $1.56 \mathrm{E}-01$ \\
\hline U-235 & $4.73 \mathrm{E}-02$ & $5.90 \mathrm{E}-03$ \\
\hline U-236 & $1.40 \mathrm{E}-01$ & $1.88 \mathrm{E}-02$ \\
\hline U-238 & $1.12 \mathrm{E}+00$ & $1.27 \mathrm{E}-01$ \\
\hline
\end{tabular}


Table 3-3. Isotopic Composition of

K East Basin Sludge.

\begin{tabular}{|l|c|c|}
\hline \multirow{2}{*}{ Nuclide } & \multicolumn{2}{|c|}{ Concentration $\left(\mathbf{C i} / \mathbf{m}^{\mathbf{3}}\right)$} \\
\cline { 2 - 3 } & Canister & Floor \\
\hline Np-237 & $8.51 \mathrm{E}-02$ & $3.97 \mathrm{E}-03$ \\
\hline Pu-238 & $8.45 \mathrm{E}+01$ & $8.29 \mathrm{E}+00$ \\
\hline Pu-239 & $3.27 \mathrm{E}+02$ & $3.34 \mathrm{E}+01$ \\
\hline Pu-240 & $1.79 \mathrm{E}+02$ & $1.84 \mathrm{E}+01$ \\
\hline Pu-241 & $9.63 \mathrm{E}+03$ & $9.86 \mathrm{E}+02$ \\
\hline Pu-242 & $8.64 \mathrm{E}-02$ & $8.85 \mathrm{E}-03$ \\
\hline Am-241 & $3.35 \mathrm{E}+02$ & $7.45 \mathrm{E}+01$ \\
\hline Total & $3.54 \mathrm{E}+04$ & $9.82 \mathrm{E}+03$ \\
\hline
\end{tabular}

$\mathrm{NA}=$ not applicable.

DCFs are taken from ICRP-68, Dose Coefficients for Intakes of Radionuclides by WorkersReplacement of ICRP Publication 61, for onsite doses, and from ICRP-72, Age Dependent Doses to Members of the Public from Intake of Radionuclides Part 5 Compilation of Ingestion and Inhalation Dose Coefficients, for offsite doses. Dose conversion factors are based on class $\mathrm{S}$ (slow) solubility, which is appropriate for oxides.

The total UDs were calculated using the RADIDOSE program (DOE/RL-2002-50, RADIDOSE for Hanford) and are $1.51 \mathrm{E}+04 \mathrm{rem} / \mathrm{g}$ onsite and $2.48 \mathrm{E}+04 \mathrm{rem} / \mathrm{g}$ offsite. This is equivalent to $2.87 \mathrm{E}+04 \mathrm{rem} / \mathrm{mL}$ onsite and $4.71 \mathrm{E}+04 \mathrm{rem} / \mathrm{mL}$ offsite. The onsite UD is applied to receptors located at $100 \mathrm{~m}$ or at the 100 Area Hanford Fire Station. The offsite UD is applied to receptors at the near bank of the Columbia River or at the Site boundary. These values are presented in Table 3-4 and are used for radiological dose consequence calculations in this report.

Table 3-4. Fifty-Year Committed Effective Dose Equivalent per Unit Respirable Milliliter or Gram of 60:40 Volume Percent Ratio of Floor to Canister Sludge Mixture Inhaled.

\begin{tabular}{|c|c|c|}
\hline \multirow{2}{*}{ Basis } & \multicolumn{2}{|c|}{ Unit dose } \\
\cline { 2 - 3 } & Onsite & Offsite \\
\hline Per unit volume basis & $2.87 \mathrm{E}+04 \mathrm{rem} / \mathrm{mL}$ & $4.71 \mathrm{E}+04 \mathrm{rem} / \mathrm{mL}$ \\
\hline Per unit mass basis & $1.51 \mathrm{E}+04 \mathrm{rem} / \mathrm{g}$ & $2.48 \mathrm{E}+04 \mathrm{rem} / \mathrm{g}$ \\
\hline
\end{tabular}

\subsubsection{Evaluation Guidelines}

Accident consequences throughout this document are classified as "low," "moderate," or "high," in accordance with HNF-PRO-700, Safety Basis Development, and are shown in Table 3-5. The evaluation guidelines shown correspond to the "moderate" consequence range. Consequences lower than this range are "low" while consequences higher than this range are "high." 
Table 3-5. Accident Consequence Classification

\begin{tabular}{|l|l|l|}
\hline & MOI & Worker \\
\hline High Consequence & $\begin{array}{l}>25 \text { rem TEDE or > EPRG-2 } / \\
\text { TEEL-2 }\end{array}$ & $\begin{array}{l}>100 \text { rem TEDE or > EPRG-3/ TEEL-3 } \\
\text { f facility boundary*, serious injury or } \\
\text { prompt death to a facility worker }\end{array}$ \\
\hline Moderate Consequence & $\begin{array}{l}\geq 1 \text { rem TEDE or > EPRG-1/ } \\
\text { TEEL-1 }\end{array}$ & $\begin{array}{l}\geq 25 \text { rem TEDE or > EPRG-2 / TEEL-2 @ } \\
\text { facility boundary*, or significant } \\
\text { radiological or chemical exposure to } \\
\text { facility workers**. }\end{array}$ \\
\hline Low Consequence & $<$ moderate consequence & < moderate consequence \\
\hline * No less than 100 meters. For elevated releases, use point of highest dose. \\
** "Significant exposure" is one that is qualitatively judged to result in immediate but reversible health effects. \\
$\begin{array}{l}\text { The location of the MOI is considered to be at the Hanford Site boundary. Other points of uncontrolled public } \\
\text { access (near bank of Columbia River, Highway 240) should be included for reference purposes. }\end{array}$ \\
\hline
\end{tabular}

The radiological evaluation guidelines used in this analysis are consistent with HNF-PRO-700, and are listed below in Table 3-6.

Table 3-6. Radiological Evaluation Guidelines.

\begin{tabular}{|c|c|}
\hline Consequence level & Safety function designation \\
\hline Offsite moderate & Safety-class SSCs to be considered \\
\hline Offsite high & Safety-class SSCs required \\
\hline Onsite moderate & Safety-significant SSCs to be considered \\
\hline Onsite high & Safety-significant SSCs required \\
\hline SSC $=$ structure, system, and component. \\
\hline
\end{tabular}

\subsubsection{Toxicological Dose Calculation Method}

To obtain the concentration of a given toxic material at the receptor, the rate of release is multiplied by the $\chi / \mathrm{Q}^{\prime}$ corresponding to that receptor. Since the concentration limits are keyed to the maximum concentration (rather than a time integrated concentration), no credit is taken for plume meander in toxicological exposure calculations.

It is recommended that the peak 15-minute time-weighted average (TWA) chemical concentration be compared with the relevant concentration-limit guideline with no adjustment of the guideline value or the calculated concentration to account for differences between the recommended 15-minute exposure time and the exposure time implicit in the definition of the concentration-limit parameter. If the toxic effects of a chemical are known to be dose-dependent (i.e., the toxic effects depend upon the total quantity of material taken up by the body) and not concentration-dependent, then for these chemicals only, the 1-hour average concentration may be used. 
In this scenario, the primary toxic material of concern is uranium (based on its heavy metal toxicity) so that a peak 15 -minute average is conservatively assumed. The equation used to calculate downwind uranium concentration is shown below.

$$
\mathrm{C}=\mathrm{Q}^{\prime} \times \chi / \mathrm{Q}^{\prime} \times \mathrm{F}
$$

where

$$
\begin{aligned}
& \mathrm{C}=\text { downwind concentration of uranium in air }\left(\mathrm{mg} / \mathrm{m}^{3}\right) \\
& \mathrm{Q}^{\prime}=\text { aerosol release rate of sludge material, }(\mathrm{L} / \mathrm{s}) \\
& \chi / \mathrm{Q}^{\prime}=\text { acute release air transport factor }\left(\mathrm{s} / \mathrm{m}^{3}\right) \\
& \mathrm{F}=\text { fraction of uranium in sludge }
\end{aligned}
$$

\subsubsection{Mass of Uranium in Sludge}

The mass of uranium in one liter of safety basis 60:40 sludge is calculated and shown in Table $3-7$ below to be $1.6 \mathrm{~g} / \mathrm{mL}$ rounded to two significant numbers. Since a $60: 40$ mixture of floor canister sludge has a density of $1.9 \mathrm{~g} / \mathrm{mL}$ (see Section 3.3.2.5) the uranium mass fraction in sludge is $1.6 / 1.9=0.84$.

Table 3-7. Grams Uranium in 1 L Safety Basis 60:40 KE Basin Sludge.

\begin{tabular}{|c|c|c|c|c|c|c|}
\hline \multirow{2}{*}{ Nuclide } & \multirow{2}{*}{ Specific Activity $(\mathbf{C i} / \mathbf{g})$} & \multicolumn{2}{|c|}{ Concentration $\left(\mathrm{Ci} / \mathbf{m}^{\mathbf{3}}\right)$} & \multicolumn{3}{|c|}{ Mass $(\mathrm{g})$} \\
\cline { 3 - 7 } & & Canister & Floor & Canister & Floor & $\mathbf{6 0 : 4 0}$ \\
\hline U-234 & $6.25 \mathrm{E}-03$ & $1.59 \mathrm{E}+00$ & $1.56 \mathrm{E}-01$ & $1.02 \mathrm{E}-01$ & $1.50 \mathrm{E}-02$ & $1.17 \mathrm{E}-01$ \\
\hline U-235 & $2.16 \mathrm{E}-06$ & $4.73 \mathrm{E}-02$ & $5.90 \mathrm{E}-03$ & $8.76 \mathrm{E}+00$ & $1.64 \mathrm{E}+00$ & $1.04 \mathrm{E}+01$ \\
\hline U-236 & $6.47 \mathrm{E}-05$ & $1.40 \mathrm{E}-01$ & $1.88 \mathrm{E}-02$ & $8.66 \mathrm{E}-01$ & $1.74 \mathrm{E}-01$ & $1.04 \mathrm{E}+00$ \\
\hline U-238 & $3.36 \mathrm{E}-07$ & $1.12 \mathrm{E}+00$ & $1.27 \mathrm{E}-01$ & $1.33 \mathrm{E}+03$ & $2.27 \mathrm{E}+02$ & $1.56 \mathrm{E}+03$ \\
\hline Total & & $2.90 \mathrm{E}+00$ & $3.08 \mathrm{E}-01$ & $1.34 \mathrm{E}+03$ & $2.29 \mathrm{E}+02$ & $1.57 \mathrm{E}+03$ \\
\hline
\end{tabular}

\subsubsection{Evaluation Guidelines}

Toxicological permissible exposure level time weighted average and emergency response planning guidelines (ERPG) were determined from the Westinghouse Safety Management Solutions database (WSMS-SAE-02-0001, ERPGs and TEELs for Chemicals of Concern). Temporary Emergency Exposure Limit (TEEL)- 1 is $0.6 \mathrm{mg} / \mathrm{m}^{3}$, TEEL-2 is $1 \mathrm{mg} / \mathrm{m}^{3}$ and TEEL-3 is $10 \mathrm{mg} / \mathrm{m}^{3}$ for uranium. HNF-PRO-700 requires a comparison of onsite chemical exposures to the ERPG or TEEL-2 values when evaluating the need for safety significant controls (see Table 3-5).

\subsection{EVALUATION BASIS ACCIDENTS}

Throughout this section a repeated reference is made to a safety basis sludge or a safety basis LDC. Two sets of physical characteristics have been provided for sludge, one called design 
basis and the other safety basis. Both sets of values are provided in HNF-SD-SNF-TI-015, Volume 2. The safety basis parameters are used in this analysis primarily in order to conservatively account for sludge behavior. A safety basis LDC has certain dimensional attributes that also are intended to conservatively represent performance. These "safety" characteristics are either based on the conservative end of experimental data or are intended to be operationally controlled. For each reference to a safety basis parameter, the value will be provided.

\subsubsection{Spray Release from Sludge Retrieval Line}

Pressurized SWS aerosol releases generally involve a failure in system containment while the system is under pressure resulting in a spray of sludge, contaminated water, or contaminated gas. The failure may occur in any of a number of components in the system. The components at risk can be loosely grouped into the following categories: pumps, pipes, fittings, connectors, pressure relief devices, and the LDCs themselves.

Several different potential causes of containment failure were identified for the SWS.

- Defect - A manufacturing defect can cause a premature failure of a component resulting in a spray release. This can be controlled in part through the use of quality components, procedures for examining components, and pressure testing the system prior to use.

- External damage - Damage to the system, through impact, fire, or environmental conditions can cause the containment system to fail.

- Internal damage - Damage to or obstruction of the internals of various SWS piping components, such as from debris in the system or hidden damage from improper operation, can result in a failure during use. This can be controlled in part through procedures, quality control inspections, and through pressure and functional testing of the system prior to use.

- Improper installation - Failure to correctly assemble the system can result in a failure during use. This can be controlled in part through procedures, quality control inspections, and through pressure and functional testing the system prior to use.

- Improper operation - The system contains valves, caps, or connectors that could be opened while the system is in use or left open prior to pressurizing the system.

Failure to correctly connect or disconnect the LDC, or failure to correctly close the LDC, also falls into this category. Such a failure could result in a spray release. This can be controlled in part through procedures and system design.

- Overpressurization due to blockage - A blockage (or a valve closure) in the system could result in a situation in which the system pressure exceeds the capacity of some component. This can be controlled in part through a system designed to withstand a maximum pressure condition or to reduce the likelihood of blockages. Procedures may be useful in reducing the likelihood of blockages. 
- Overpressurization from hydrogen burn inside the LDC - A hydrogen burn could result in a containment failure.

- Overpressurization from heating - If the system were heated (such as from a fire), it could pressurize to the point that a component could fail and initiate a spray release.

\subsubsection{Scenario Development}

The Sludge Retrieval System (SRS) consists of several piping systems for sludge retrieval, overflow piping, water addition, gas venting, and argon purging.

The sludge retrieval pipe comprises both underwater lines and above-water lines and both hard pipe and flexible hose. The flexible hose is connected to the LDC via a manual coupling device. This is the most likely place for a leak to occur and release sludge aerosol directly into the environment. This could be caused by a failure of the coupling seal, damage to the coupling, or human error in making the connection. When the coupling is first installed, water is run through the system to fill the LDC. Therefore, a leak in the coupling would likely be discovered at this point and the consequences would be minimal. However, it is still possible for the coupling to fail while in a sludge retrieval mode. This leak scenario would also conservatively bound leaks in other less likely parts of the system.

\subsubsection{Source Term Analysis}

The amount of sludge that may leak into the environment is a function of the hole size, the fluid pressure, and the duration of the leak. These parameters are somewhat interdependent and so must be chosen carefully. It is possible that the discharge could be blocked due to a closed water return valve on the overflow piping, a blinded filter system in the LDC, or a plugged discharge line. A blocked discharge essentially causes a deadhead condition at the pump and maximizes the release pressure at the leak location. In this case the pressure differential is $75 \mathrm{lb} / \mathrm{in}^{2}$, which is the pump deadhead pressure.

The material, aerosolized and potentially transportable, can be quantified using the ARF. The product of the leak rate and the ARF is the ARR. A slit-type leak, such as might occur from a misaligned or failed fitting or a weld crack was chosen to represent this spray release. It is reasonable to base the length of the slit on the pipe diameter. The slurry pipe is a 2-in., schedule 40 pipe so the slit length considered here is $2 \mathrm{in}$. The slit depth is taken to be the wall thickness of the piping.

The ARF is in general inversely proportional to the crack width, so a smaller width is conservative. At some sufficiently small crack width, however, the sludge solids will tend to plug the crack. Industry experience with fuel atomizers suggests that dimensions less than $0.3 \mathrm{~mm}$ to $0.5 \mathrm{~mm}$ are particularly prone to plugging (see Lefebvre [1989], Atomization and Sprays [pages 4 and 110]). Given the large quantity of solids present, it is expected that the sludge will be much more prone to plugging in this application and that the range provided in Lefebvre (1989) can be considered a practical lower bound on the crack width. In order to quantify the sensitivity of the results to this parameter, different widths in this range are evaluated. 
The SPRAY code described in WHC-SD-GN-SWD-20007, A Model for Predicting Respirable Release from Pressurized Leaks, was used to determine the ARF for small slit widths. One of the inputs required by the SPRAY code is the maximum respirable droplet size. This is generally assumed to be $10 \mu \mathrm{m}$; however, for aerosol that includes a mixture of water and other material, some consideration should be given to larger droplets that could rapidly evaporate to a respirable size. If too large, the droplet will fall out before reaching the receptor (100-m for the maximum onsite individual). In order to establish the maximum size of concern for the SPRAY code, the time to fall out is compared with the travel time. For spherical water droplets, Hinds (1982), Aerosol Technology - Properties, Behavior, and Measurement of Airborne Particles provides the following relationship:

$$
\mathrm{V}_{\mathrm{TS}}=0.003 \mathrm{~d}^{2}(\text { for } 1<\mathrm{d}<100 \mu \mathrm{m})
$$

where

$$
\begin{array}{lll}
\mathrm{V}_{\mathrm{TS}} & = & \text { settling velocity }(\mathrm{cm} / \mathrm{s}) \\
\mathrm{d} & = & \text { droplet diameter }(\mu \mathrm{m}) .
\end{array}
$$

A $20-\mu \mathrm{m}$ droplet will result in a settling velocity of $1.2 \mathrm{~cm} / \mathrm{s}$. Assuming a release height of $2 \mathrm{~m}$, such a droplet will fall out within 2.8 minutes. This is about the length of time it would take for aerosols to escape the basin superstructure and be carried downwind to the onsite receptor at $100 \mathrm{~m}$ given the wind speeds applicable to the $\chi / \mathrm{Q}^{\prime}$ values used in this analysis. Evaporation and settling occur simultaneously, but in the vicinity of the spray release, the humidity is high and little evaporation will occur. Therefore, a maximum transportable diameter of $20 \mu \mathrm{m}$ was used as input to the SPRAY code. The density and viscosity of the slurry mixture, which are also used as inputs to the SPRAY code, are conservatively assumed to be that for water.

Another consideration in evaluating the consequences of a leak of suspended solids is that most of the leak consists of basin water, which can be ignored as a hazard in comparison with the sludge. Physically the volume fraction of sludge in the slurry line cannot be much above $30 \%$ and still be pumped. If the scenario involves a blocked discharge, there is relatively little flow out the leak and a much lower suspended solids fraction would result due to settling in the pipes. For the case of a blocked discharge, the volume fraction of sludge exiting the leak is assumed to be $1 \%$. Otherwise the leak will be more apt to plug than to continue leaking.

The SPRAY code output is provided in Appendix A. A summary of results is presented in Table 3-8 for three slit widths under $75 \mathrm{lb} / \mathrm{in}^{2}$ differential pressure and one slit width under $45 \mathrm{lb} / \mathrm{in}^{2}$ differential pressure. The $75 \mathrm{lb} / \mathrm{in}^{2}$ cases represent a blocked discharge, where no sludge flows into the LDC. The release duration is taken as 8 hours, which is the maximum recommended in DOE-STD-3009-94 for use in dose calculations. The first row of results in Table 3-8 is provided to indicate the sensitivity of the source term to the slit width. The $0.114-\mathrm{mm}$ slit width is optimal for maximizing the respirable release but is smaller than that which would be expected to plug. Therefore the second row, using a slit width at the lower range of plugging, should be considered a reasonable source term for the unmitigated spray release. Note that the total leak rate is still only $5.4 \mathrm{gal} / \mathrm{min}$, which is consistent with a pump pressure near its deadhead value. This leak rate, over the course of 8 hours, results in a total 
release of nearly $100 \mathrm{~L}$ of sludge, which is a highly conservative assumption. The third row, with a slit width of $0.5 \mathrm{~mm}$, the upper range of plugging, has a source term $50 \%$ smaller than the second row.

The fourth row is the $45 \mathrm{lb} / \mathrm{in}^{2}$ case, which represents a spray release with correctly aligned valves. Here, sludge is flowing into the LDC at the design flow rate of $60 \mathrm{gal} / \mathrm{min}$. At this flow rate, and assuming the maximum slurry solids fraction of $30 \%$, it would take 7.3 minutes to transfer $0.5 \mathrm{~m}^{3}$ of sludge. This scenario is explained in Section 3.4.1.5.

Table 3-8. Airborne Release Fraction for Different Crack Widths.

\begin{tabular}{|l|l|l|l|l|l|l|l|}
\hline $\begin{array}{l}\text { Crack width } \\
\text { and pressure }\end{array}$ & $\begin{array}{c}\text { Slurry leak } \\
\text { rate } \\
(\mathrm{L} / \mathrm{s})\end{array}$ & ARF & $\begin{array}{c}\text { Sludge } \\
\text { volume } \\
\text { fraction } \\
\text { in slurry }\end{array}$ & RF & $\begin{array}{c}\text { Respirable } \\
\text { sludge } \\
\text { release } \\
\text { rate } \\
(\mathbf{L} / \mathbf{s})\end{array}$ & $\begin{array}{c}\text { Release } \\
\text { duration }\end{array}$ & $\begin{array}{c}\text { Source } \\
\text { term } \\
\text { (mL) }\end{array}$ \\
\hline $\begin{array}{l}0.114 \mathrm{~mm} \\
\text { optimal at } \\
75 \mathrm{lb} / \mathrm{in}^{2}\end{array}$ & $\begin{array}{l}9.09 \mathrm{E}-02 \\
(1.4 \mathrm{gal} / \mathrm{min})\end{array}$ & $1.09 \mathrm{E}-02$ & 0.01 & 1.0 & $9.9 \mathrm{E}-06$ & 8 hours & 290 \\
\hline $\begin{array}{l}0.3 \mathrm{~mm} \text { lower } \\
\text { plug range at } \\
75 \mathrm{lb} / \mathrm{in}^{2}\end{array}$ & $\begin{array}{l}3.40 \mathrm{E}-01 \\
(5.4 \mathrm{gal} / \mathrm{min})\end{array}$ & $1.61 \mathrm{E}-03$ & 0.01 & 1.0 & $5.5 \mathrm{E}-06$ & 8 hours & 160 \\
\hline $\begin{array}{l}0.5 \mathrm{~mm} \text { upper } \\
\text { plug range at } \\
75 \mathrm{lb} / \mathrm{in}^{2}\end{array}$ & $\begin{array}{l}6.16 \mathrm{E}-01 \\
(9.8 \mathrm{gal} / \mathrm{min})\end{array}$ & $4.54 \mathrm{E}-04$ & 0.01 & 1.0 & $2.8 \mathrm{E}-06$ & 8 hours & 81 \\
\hline $\begin{array}{l}0.3 \mathrm{~mm} \text { lower } \\
\text { plug range at } \\
45 \mathrm{lb} / \mathrm{in}^{2}\end{array}$ & $\begin{array}{l}2.63 \mathrm{E}-01 \\
(4.2 \mathrm{gal} / \mathrm{min})\end{array}$ & $8.73 \mathrm{E}-04$ & 0.3 & 0.25 & $1.72 \mathrm{E}-05$ & 7.3 & 7.5 \\
\hline
\end{tabular}

$\mathrm{ARF}=$ airborne release fraction.

$\mathrm{RF}=$ respirable fraction.

\subsubsection{Consequence Analysis}

The dose at each location of interest can be determined by using Equation 3-2 (along with the BR and UD), the atmospheric transport factors (for a 1- to 2-hour release) from Table 3-2, and the $160-\mathrm{mL}$ source term value from the previous section. The resulting values are shown in Table 3-9.

Table 3-9. Summary of Maximum Dose Consequences for Unmitigated Pressurized Aerosol Release (Blocked Discharge and $0.3 \mathrm{~mm}$ Slit Opening).

\begin{tabular}{|l|c|c|c|}
\hline \multicolumn{1}{c|}{$\begin{array}{c}\text { Receptor location } \\
\text { (distance, direction) }\end{array}$} & \multicolumn{2}{|c|}{ Unmitigated } & \multirow{2}{*}{$\begin{array}{c}\text { Evaluation guidelines } \\
\text { (rem) }\end{array}$} \\
\cline { 2 - 4 } & $\chi / \mathbf{Q}^{\prime}$ & rem & 25 to 100 \\
\hline $\begin{array}{l}\text { Onsite } \\
(100 \mathrm{~m}, \mathrm{E})\end{array}$ & $1.24 \mathrm{E}-02$ & $1.9 \mathrm{E}+01$ & -- \\
\hline $\begin{array}{l}\text { Columbia River, near bank } \\
(520 \mathrm{~m}, \mathrm{~W})\end{array}$ & $6.17 \mathrm{E}-04$ & $1.5 \mathrm{E}+00$ & -- \\
\hline $\begin{array}{l}100 \text { Area Fire station } \\
(3,750 \mathrm{~m}, \mathrm{ESE})\end{array}$ & $7.82 \mathrm{E}-05$ & $1.2 \mathrm{E}-01$ & \\
\hline
\end{tabular}


Table 3-9. Summary of Maximum Dose Consequences for Unmitigated Pressurized Aerosol Release (Blocked Discharge and $0.3 \mathrm{~mm}$ Slit Opening).

\begin{tabular}{|c|c|c|c|}
\hline \multirow{2}{*}{$\begin{array}{l}\text { Receptor location } \\
\text { (distance, direction) }\end{array}$} & \multicolumn{2}{|c|}{ Unmitigated } & \multirow{2}{*}{$\begin{array}{l}\text { Evaluation guidelines } \\
\text { (rem) }\end{array}$} \\
\hline & $\chi / Q^{\prime}$ & rem & \\
\hline $\begin{array}{l}\text { Hanford Site boundary } \\
(10,070 \mathrm{~m}, \mathrm{~W})\end{array}$ & $3.12 \mathrm{E}-05$ & $7.8 \mathrm{E}-02$ & 1 to 25 \\
\hline
\end{tabular}

The toxicological consequences of the release can be calculated using Equation 3-4 (along with the sludge density and $U$ fraction from Section 3.3.3.1). The 5.5E-06-mL/s source term is taken from Table 3-8, and the acute release $\chi / Q$ 's from Table 3-2 are used. Results are shown in Table 3-10.

Table 3-10. Downwind Uranium Concentration for Unmitigated Pressurized Aerosol Release (Blocked Discharge and $0.3 \mathrm{~mm}$ Slit Opening).

\begin{tabular}{|l|c|c|c|}
\hline \multicolumn{1}{|c|}{$\begin{array}{c}\text { Receptor location } \\
\text { (distance, direction) }\end{array}$} & $\begin{array}{c}\boldsymbol{\chi} / \mathbf{Q}^{\prime} \\
\left(\mathbf{s} / \mathbf{m}^{\mathbf{3}}\right)\end{array}$ & $\begin{array}{c}\text { Concentration } \\
\left(\mathbf{m g} / \mathbf{m}^{\mathbf{3}}\right)\end{array}$ & $\begin{array}{c}\text { Evaluation guidelines } \\
\left(\mathbf{m g} / \mathbf{m}^{\mathbf{3}}\right)\end{array}$ \\
\hline $\begin{array}{l}\text { Onsite } \\
(100 \mathrm{~m}, \mathrm{E})\end{array}$ & $7.32 \mathrm{E}-02$ & $6.4 \mathrm{E}-01$ & $\begin{array}{c}1 \text { to } 10 \\
\text { (EPRG-2 to EPRG-3) }\end{array}$ \\
\hline $\begin{array}{l}\text { Columbia River, near bank } \\
(520 \mathrm{~m}, \mathrm{~W})\end{array}$ & $3.55 \mathrm{E}-03$ & $3.1 \mathrm{E}-02$ & - \\
\hline $\begin{array}{l}100 \text { Area Fire station } \\
(3,750 \mathrm{~m}, \mathrm{ESE})\end{array}$ & $1.60 \mathrm{E}-04$ & $1.4 \mathrm{E}-03$ & -- \\
\hline $\begin{array}{l}\text { Hanford Site boundary } \\
(10,070 \mathrm{~m}, \mathrm{~W})\end{array}$ & $4.49 \mathrm{E}-05$ & $3.9 \mathrm{E}-04$ & $\begin{array}{c}0.6 \text { to I } \\
\text { (EPRG-1 to EPRG-2) }\end{array}$ \\
\hline
\end{tabular}

\subsubsection{Comparison to Guidelines}

Radiological and toxicological consequences for the unmitigated spray event are within the "low" consequence bin. Therefore no preventive or mitigative controls are warranted.

\subsubsection{Mitigation or Prevention Analyses}

Two ways to mitigate a spray release of hazardous aerosol are discussed here. One is the use of spray shields; and the second is preventing a dead-head condition (e.g., by ensuring that valves are properly aligned).

Of the aerosols that are transportable solid sludge particulates, only a fraction are respirable (i.e., $<10 \mu \mathrm{m}$ AED). Based on various sludge samples described in 30855-05, Compilation and Integration of K Basin Particle Size Analysis Data (Figures S.1 and S.2), no more than 25\% of the sludge particles are respirable. The RF, therefore, is set at 0.25 for this analysis.

The first mitigation approach is through the use of spray shields, such that if a leak should occur it would not spray aerosol directly into the environment but would impinge on a spray shield and result in a spill release. The hazard to personnel from this case would be from splash and splatter of the sludge. Using the same $0.34 \mathrm{~L} / \mathrm{s}$ leak rate and $1 \%$ solids fraction as the unmitigated case, the ARF for splash/splatter (see Section 3.4.2), and the RF given above, the mitigated source 
term is $1.22 \mathrm{~mL}$ for an 8 -hour release. The onsite consequences for a mitigated spray are shown in Table 3-11.

Table 3-11. Summary of Maximum Dose Consequences for Pressurized Aerosol Release Mitigated by Spray Shields.

\begin{tabular}{|c|c|c|c|}
\hline \multirow{2}{*}{$\begin{array}{l}\text { Receptor location } \\
\text { (distance, direction) }\end{array}$} & \multicolumn{2}{|c|}{ Unmitigated } & \multirow{2}{*}{$\begin{array}{l}\text { Evaluation guidelines } \\
\text { (rem) }\end{array}$} \\
\hline & $\chi / Q^{\prime}$ & rem & \\
\hline $\begin{array}{l}\text { Onsite } \\
(100 \mathrm{~m}, \mathrm{E})\end{array}$ & $1.24 \mathrm{E}-02$ & $1.4 \mathrm{E}-01$ & 25 to 100 \\
\hline $\begin{array}{l}\text { Columbia River, near bank } \\
(520 \mathrm{~m}, \mathrm{~W})\end{array}$ & 6.17 E-04 & $1.2 \mathrm{E}-02$ & -- \\
\hline $\begin{array}{l}100 \text { Area Fire station } \\
(3,750 \mathrm{~m}, \mathrm{ESE})\end{array}$ & $7.82 \mathrm{E}-05$ & $9.1 \mathrm{E}-04$ & -- \\
\hline $\begin{array}{l}\text { Hanford Site boundary } \\
(10,070 \mathrm{~m}, \mathrm{~W})\end{array}$ & $3.12 \mathrm{E}-05$ & $6.0 \mathrm{E}-04$ & 1 to 25 \\
\hline
\end{tabular}

The mitigated toxicological consequences are found using Equation 3-4 as described above for the unmitigated case. The release rate is $1.22 \mathrm{~mL}$ divided by 8 hours, or $4.25 \mathrm{E}-08 \mathrm{~L} / \mathrm{s}$. This quantity is converted to grams using the sludge density given in Section 3.3.2.5. The mitigated toxicological consequences are shown in Table 12.

Table 3-12. Downwind Uranium Concentration for Pressurized Aerosol Release Mitigated by Spray Shields.

\begin{tabular}{|l|c|c|c|}
\hline \multicolumn{1}{|c|}{$\begin{array}{c}\text { Receptor location } \\
\text { (distance, direction) }\end{array}$} & $\begin{array}{c}\chi / \mathbf{Q}^{\prime} \\
\left(\mathbf{s} / \mathbf{m}^{\mathbf{3}}\right)\end{array}$ & $\begin{array}{c}\text { Concentration } \\
\left(\mathbf{m g} / \mathbf{m}^{\mathbf{3}}\right)\end{array}$ & $\begin{array}{c}\text { Evaluation guidelines } \\
\left(\mathbf{m g} / \mathbf{m}^{\mathbf{3}}\right)\end{array}$ \\
\hline $\begin{array}{l}\text { Onsite } \\
(100 \mathrm{~m}, \mathrm{E})\end{array}$ & $7.32 \mathrm{E}-02$ & $5.0 \mathrm{E}-03$ & 1 to 10 \\
\hline $\begin{array}{l}\text { Columbia River, near bank } \\
(520 \mathrm{~m}, \mathrm{~W})\end{array}$ & $3.55 \mathrm{E}-03$ & $2.4 \mathrm{E}-04$ & -- \\
\hline $\begin{array}{l}100 \text { Area Fire station } \\
(3,750 \mathrm{~m}, \mathrm{ESE})\end{array}$ & $1.60 \mathrm{E}-04$ & $1.1 \mathrm{E}-05$ & -- \\
\hline $\begin{array}{l}\text { Hanford Site boundary } \\
(10,070 \mathrm{~m}, \mathrm{~W})\end{array}$ & $4.49 \mathrm{E}-05$ & $3.0 \mathrm{E}-06$ & 0.6 to 1 \\
\hline
\end{tabular}

The mitigated consequences (radiological and toxicological) are within the "low" consequence bin, and show that spray shields can successfully mitigate a spray leak.

Note that this is not the worst case of a mitigated spray release, only the mitigation of the worst case spray. A higher flow rate leak would be a less efficient atomizer, but result in more $\mathrm{splash} / \mathrm{splatter}$ than the optimum spray leak. The worst case here would be an open-ended break of the piping inside the spray shield, resulting in a spill of the design flow $60 \mathrm{gpm}$. This is identical to the sludge spill accident discussed in Section 3.4.2. The second mitigation approach is to prevent a pump deadhead condition by ensuring proper valve alignment. In this situation, the maximum expected pressure at the LDC disconnects would be approximately $45 \mathrm{lb} / \mathrm{in}^{2}$. The fourth row in Table 3-7 shows the respirable source term to be $7.5 \mathrm{~mL}$ for this case. Note that the release duration is potentially only 7.3 minutes because the discharge path is open and that is 
how long it would take to transfer $0.5 \mathrm{~m}^{3}$ of sludge given that the slurry is 30 vol\% sludge and the pump rate is $60 \mathrm{gal} / \mathrm{min}$. These mitigated results are shown in Table 3-13.

Table 3-13. Summary of Maximum Dose Consequences for Pressurized Aerosol Release Mitigated By Open Discharge Into the LDC.

\begin{tabular}{|l|c|c|c|}
\hline \multicolumn{1}{|c|}{$\begin{array}{c}\text { Receptor location } \\
\text { (distance, direction) }\end{array}$} & $\chi / \mathrm{Q}^{\prime}$ & rem & $\begin{array}{c}\text { Evaluation guidelines } \\
\text { (rem) }\end{array}$ \\
\cline { 2 - 4 } & $7.32 \mathrm{E}-02$ & $5.2 \mathrm{E}+00$ & 25 to 100 \\
\hline $\begin{array}{l}\text { Onsite } \\
(100 \mathrm{~m}, \mathrm{E})\end{array}$ & $3.55 \mathrm{E}-03$ & $4.2 \mathrm{E}-01$ & -- \\
\hline $\begin{array}{l}\text { Columbia River, near bank } \\
(520 \mathrm{~m}, \mathrm{~W})\end{array}$ & $1.60 \mathrm{E}-04$ & $1.1 \mathrm{E}-02$ & -- \\
\hline $\begin{array}{l}100 \text { Area Fire Station } \\
(3,750 \mathrm{~m}, \mathrm{ESE})\end{array}$ & $4.49 \mathrm{E}-05$ & $5.3 \mathrm{E}-03$ & 1 to 25 \\
\hline $\begin{array}{l}\text { Hanford Site boundary } \\
(10,070 \mathrm{~m}, \mathrm{~W})\end{array}$ & & \multicolumn{2}{|c|}{} \\
\hline
\end{tabular}

The mitigated toxicological consequences are found using Equation 3-4 as described above for the unmitigated case. The release rate is $7.5 \mathrm{~mL}$ divided by 15 minutes, or $8.33 \mathrm{E}-06 \mathrm{~L} / \mathrm{s}$. The mitigated toxicological consequences are shown in Table 14.

Table 3-14. Downwind Uranium Concentration for Pressurized Aerosol Release Mitigated by Open Discharge Into the LDC.

\begin{tabular}{|l|c|c|c|}
\hline \multicolumn{1}{|c|}{$\begin{array}{c}\text { Receptor location } \\
\text { (distance, direction) }\end{array}$} & $\begin{array}{c}\chi / \mathbf{Q}^{\prime} \\
\left(\mathbf{s} / \mathbf{m}^{\mathbf{3}}\right)\end{array}$ & $\begin{array}{c}\text { Concentration } \\
\left(\mathbf{m g} / \mathbf{m}^{3}\right)\end{array}$ & $\begin{array}{c}\text { Evaluation guidelines } \\
\left(\mathbf{m g} / \mathbf{m}^{\mathbf{3}}\right)\end{array}$ \\
\hline $\begin{array}{l}\text { Onsite } \\
(100 \mathrm{~m}, \mathrm{E})\end{array}$ & $7.32 \mathrm{E}-02$ & $9.7 \mathrm{E}-01$ & 1 to 10 \\
\hline $\begin{array}{l}\text { Columbia River, near bank } \\
(520 \mathrm{~m}, \mathrm{~W})\end{array}$ & $3.55 \mathrm{E}-03$ & $4.7 \mathrm{E}-02$ & -- \\
\hline $\begin{array}{l}100 \text { Area Fire station } \\
(3,750 \mathrm{~m}, \mathrm{ESE})\end{array}$ & $1.60 \mathrm{E}-04$ & $2.1 \mathrm{E}-03$ & -- \\
\hline $\begin{array}{l}\text { Hanford Site boundary } \\
(10,070 \mathrm{~m}, \mathrm{~W})\end{array}$ & $4.49 \mathrm{E}-05$ & $6.0 \mathrm{E}-04$ & $\begin{array}{c}0.6 \text { to } 1 \\
\text { (EPRG-1 to EPRG-2) }\end{array}$ \\
\hline
\end{tabular}

Although the mitigated radiological consequences are within "low" guidelines, the mitigated toxicological consequences are at the guideline. This mitigation approach is therefore less effective than mitigation by spray shields.

\subsubsection{Summary of Safety Structures, Systems, and Components and Technical Safety Requirement Controls}

Although safety significant controls are not required to prevent or mitigate this accident, the following TSR-level administrative controls on sludge retrieval and shipment preparation are necessary to safeguard source term assumptions used in the analysis:

- LDCs shall be loaded in batches less than or equal to $0.5 \mathrm{~m}^{3}$ with an 8-hour settling time between batches. Limiting the maximum batch size to $0.5 \mathrm{~m}^{3}$ allows the lighter 
particles (i.e., non-uranium metal) to settle out in between uranium metal layers so that the uranium metal is spatially distributed in at least four layers.

- For canister-floor sludge, each $0.5 \mathrm{~m}^{3}$ batch shall consist of both canister sludge and its associated floor sludge (to preserve the 60:40 mixture basis). The spatial distribution of floor and canister sludge is not uniform, but it can be conservatively represented by a 60:40-volume ratio of floor to canister sludge in any given area large enough to yield a $2 \mathrm{~m}^{3} \mathrm{LDC}$ payload or even a $0.5 \mathrm{~m}^{3}$ batch. Therefore, as long as both floor and canister sludge are picked up in any area used to fill a $0.5 \mathrm{~m}^{3}$ batch, the 60:40 analysis assumption remains valid. It is estimated that at least 70 canisters of sludge and the sludge on the floor beneath those canisters would be needed to fill a $0.5 \mathrm{~m}^{3}$ batch. This can be used as operational guidance for meeting the $0.5 \mathrm{~m}^{3} /$ day limit. The actual batch volume would be confirmed by direct measurement.

\subsubsection{Sludge Spill/Contamination Spread}

The hazards associated with the spread of contamination are attributable to the spilling (as opposed to spraying) of sludge to the environment. From SNF-10020, the hazards analysis performed on the SWS, the following potential release paths were identified:

- Potential rupture of process lines or LDC due to freezing

- Sludge pumped into the facility due to damage or improper installation of the confinement system and improper operation allowing a leak to occur unnoticed for a specific period of time

The quantity, location, and type of sludge released to the environment as a consequence of the hazards outlined above can vary depending on the scenario developed for the accident. The quantity of sludge released can range from very small quantities to several hundred liters as in the case of a full break in the process line going to the LDC. The sludge could be released to accumulate within the cask under the process shield plate or to a location completely exposed to the north transfer bay environment. The type of sludge released can vary between the canister sludge vacuumed directly above the fuel elements to the sludge found on the basin floor. All these parameters impact the MAR for this class of hazard.

One possibility is a large spill that is released quickly. The consequences in this case would be from splash and splatter of the sludge.

Another possibility is a small spill that is unnoticed. In this case, consequences would be from splash/splatter and from resuspension of dried sludge.

\subsubsection{Scenario Development}

The Sludge Retrieval System consists of several piping systems for sludge retrieval, water return, water wash, gas venting, and argon purging. The worst place for a leak to occur is in the sludge retrieval pipe since this has the highest concentration of sludge. The sludge retrieval pipe comprises both underwater lines and above-water lines, both hard pipe and flexible hose. The 
flexible hose is connected to the LDC via remote manual coupling devices. This is the most likely place for a leak to occur that would release sludge directly into the environment. (The release of sludge into the cask is not analyzed because it is bounded by the release of sludge into the open environment.) The leak could be caused by a failure of the coupling seal, damage to the coupling, or human error in making the connection. When the coupling is first installed, water is run through the system to fill the LDC. Therefore, a leak in the coupling would likely be discovered and the consequences would be minimal. However, it is still possible for the coupling to fail while in a sludge retrieval mode. This leak scenario would also conservatively represent leaks in other less likely parts of the system.

The sludge-water mixture in the process lines to the LDC is assumed to leak near the manual couplings and drip onto the transport trailer platform or facility floor. The sludge-water mixture for the small unnoticed spill case is also analyzed after it has formed a dry resuspensible powder.

\subsubsection{Source Term Analysis}

The MAR under this scenario is the quantity of sludge that has leaked from the process lines during the period of filling one LDC. One can envision a range in the quantity of sludge leaked from the system. For this analysis, $500 \mathrm{~L}\left(0.5 \mathrm{~m}^{3}\right)$ of sludge is assumed to have leaked from the confinement system and to be directly exposed to the environment. Administratively, the sludge retrieved during a batch run will be limited to $0.5 \mathrm{~m}^{3}$ in order to allow the smaller sludge particulates time to settle in the LDC (see Section 3.4.3). Because of limitations on the area that can be vacuumed during one shift, it will take at least several shifts to complete a $0.5-\mathrm{m}^{3}$ batch, the MAR assumption is reasonably conservative.

According to Section 3.2.3.2 of DOE-HDBK-3010-94, the dripping of the sludge-water mixture onto the floor represents a slurry spill. The corresponding recommended ARF for a drop of greater than $3 \mathrm{~m}$ is $5 \times 10^{-5}$. The RF for the KE Basin sludge has been estimated to be 0.25 (see discussion in Section 3.4.1.5). From Equation 3-1, the equivalent volume in liters of respirable sludge aerosol released to the environment for this mechanism is estimated to be as follows:

$$
\mathrm{Q}_{\text {spill }}=500 \mathrm{~L} \times 1 \times\left(5 \times 10^{-5}\right) \times 0.25 \times 1=6.25 \times 10^{-3} \mathrm{~L}
$$

where DR and LPF equal 1 for the release.

Two source terms have been identified for the small unnoticed spill: the dripping of the sludgewater mixture onto the trailer platform or facility floor and the resuspension of dried sludge from the floor. The volume of waste leaked will be initially assumed to be $1 \mathrm{~L}$. The amount of respirable aerosol generated by splash/splatter here is:

$$
\mathrm{Q}_{\text {spill }}=1 \mathrm{~L} \times 1 \times\left(5 \times 10^{-5}\right) \times 0.25 \times 1=1.25 \times 10^{-5} \mathrm{~L}
$$

According to Section 4.4.4.1.2 of DOE-HDBK-3010-94, the bounding ARR for powders resuspended from aerodynamic or mechanical stresses is $4 \times 10^{-5} / \mathrm{h}$. It is assumed that all resuspended powder is respirable. To determine the quantity of material resuspended, the duration of the resuspension mechanisms must be chosen. A duration of 12 hours has been selected to represent a nominal accident. From Equation 3-1, the equivalent volume in liters of 
respirable sludge aerosol released to the environment for this mechanism is estimated to be as follows:

$$
\mathrm{Q}_{\mathrm{a} / \mathrm{m} \mathrm{stress}}=1 \mathrm{~L} \times 1 \times\left(4 \times 10^{-5} / \mathrm{h}\right) \times 12 \mathrm{~h} \times 1.0 \times 1=4.80 \times 10^{-4} \mathrm{~L}
$$

where DR and LPF equal 1 for the release.

It should be noted that the estimated respirable sludge aerosol, $\mathrm{Q}_{\mathrm{a} / \mathrm{m} \text { stress, }}$, released to the environment from aerodynamic and mechanical stresses on the dried sludge is more than a factor of 30 larger than the estimated aerosol, $\mathrm{Q}_{\text {spill, }}$, released to the environment from the spilling of the sludge-water mixture onto the facility floor.

The toxicological source terms are derived from the radiological source terms. To find the release rate (ARR), divide the total release by the release time. For the 500-L case, dividing $6.25 \mathrm{~mL}$ by 15 minutes (see Section 3.3.3) yields a release rate of $6.94 \mathrm{E}-06 \mathrm{~L} / \mathrm{s}$. For the $1-\mathrm{L}$ splash/splatter case, dividing $1.25 \mathrm{E}-05 \mathrm{~L}$ by 15 minutes yields a release rate of $1.39 \mathrm{E}-08 \mathrm{~L} / \mathrm{s}$. For the $1-\mathrm{L}$ resuspension case, dividing $4.80 \mathrm{E}-04 \mathrm{~L}$ by 12 hours yields a release rate of $1.11 \mathrm{E}-08 \mathrm{~L} / \mathrm{s}$.

\subsubsection{Consequence Analysis}

For the 500-L spill, the dose at each location of interest can be determined by using Equation 3-2 and the $6.25-\mathrm{mL}$ source term values from the previous section. The breathing rate and UDs are from Section 3.3.2. Acute release $\chi / Q^{\prime}$ s from Table 3-2 are used for conservatism. The resulting values are shown in Table 3-15.

Table 3-15. Summary of Dose Consequences for Splash/Splatter of 500-L Sludge Spill.

\begin{tabular}{|l|l|l|c|}
\hline \multicolumn{1}{c|}{$\begin{array}{c}\text { Receptor location } \\
\text { (distance, direction) }\end{array}$} & \multicolumn{1}{|c|}{ Unmitigated } & \multicolumn{1}{c|}{$\begin{array}{c}\text { Evaluation guidelines } \\
\text { (rem) }\end{array}$} \\
\cline { 2 - 3 } & $7.32 \mathrm{E}-02$ & $4.4 \mathrm{E}+00$ & 25 to 100 \\
\hline $\begin{array}{l}\text { Onsite } \\
(100 \mathrm{~m}, \mathrm{E})\end{array}$ & $3.55 \mathrm{E}-03$ & $3.5 \mathrm{E}-01$ & -- \\
\hline $\begin{array}{l}\text { Columbia River, near bank } \\
(520 \mathrm{~m}, \mathrm{~W})\end{array}$ & $1.60 \mathrm{E}-04$ & $9.6 \mathrm{E}-03$ & -- \\
\hline $\begin{array}{l}100 \text { Area Fire Station } \\
(3,750 \mathrm{~m}, \text { ESE) }\end{array}$ & $4.49 \mathrm{E}-05$ & $4.4 \mathrm{E}-03$ & 1 to 25 \\
\hline $\begin{array}{l}\text { Hanford Site boundary } \\
(10,070 \mathrm{~m}, W)\end{array}$ & &
\end{tabular}

The toxicological consequences are found using Equation 3-4 (along with the sludge density and $\mathrm{U}$ fraction from Section 3.3.3.1). The release rate is $6.94 \mathrm{E}-06 \mathrm{~L} / \mathrm{s}$ as shown above. Acute release $\chi / Q$ 's from Table 3-2 are used. The toxicological consequences are shown in Table 16. 
Table 3-16. Downwind Uranium Concentration for Splash/Splatter of 500-L Sludge Spill.

\begin{tabular}{|l|c|c|c|}
\hline \multicolumn{1}{|c|}{$\begin{array}{c}\text { Receptor location } \\
\text { (distance, direction) }\end{array}$} & $\begin{array}{c}\boldsymbol{\chi} / \mathbf{Q}^{\prime} \\
\left(\mathbf{s} / \mathbf{m}^{\mathbf{3}}\right)\end{array}$ & $\begin{array}{c}\text { Concentration } \\
\left(\mathbf{m g} / \mathbf{m}^{\mathbf{3}}\right)\end{array}$ & $\begin{array}{c}\text { Evaluation guidelines } \\
\left(\mathbf{m g} / \mathbf{m}^{\mathbf{3}}\right)\end{array}$ \\
\hline $\begin{array}{l}\text { Onsite } \\
(100 \mathrm{~m}, \mathrm{E})\end{array}$ & $7.32 \mathrm{E}-02$ & $8.1 \mathrm{E}-01$ & 1 to 10 \\
\hline $\begin{array}{l}\text { Columbia River, near bank } \\
(520 \mathrm{~m}, \mathrm{~W})\end{array}$ & $3.55 \mathrm{E}-03$ & $3.9 \mathrm{E}-02$ & -- \\
\hline $\begin{array}{l}100 \text { Area Fire station } \\
(3,750 \mathrm{~m}, \mathrm{ESE})\end{array}$ & $1.60 \mathrm{E}-04$ & $1.8 \mathrm{E}-04$ & -- \\
\hline $\begin{array}{l}\text { Hanford Site boundary } \\
(10,070 \mathrm{~m}, \mathrm{~W})\end{array}$ & $4.49 \mathrm{E}-05$ & $5.0 \mathrm{E}-04$ & $\begin{array}{c}\text { (EPR-2 to EPRG-3) } 1 \\
\text { (EPRG-1 to EPRG-2) }\end{array}$ \\
\hline
\end{tabular}

For the 1-L spill, both splash/splatter and resuspension are considered. Equation 3-2 is used to calculate dose consequences for both cases. The breathing rate and UDs are from Section 3.3.2.

For splash/splatter, the acute release $\chi / \mathrm{Q}^{\prime}$ values are used. The source term is $1.25 \mathrm{E}-02 \mathrm{~mL}$ as given above. Consequences are shown in Table 3-17.

Table 3-17. Summary of Dose Consequences for Splash/Splatter of 1-L Sludge Spill.

\begin{tabular}{|c|c|c|c|}
\hline \multirow{2}{*}{$\begin{array}{l}\text { Receptor location } \\
\text { (distance, direction) }\end{array}$} & \multicolumn{2}{|c|}{ Unmitigated } & \multirow{2}{*}{$\begin{array}{l}\text { Evaluation guidelines } \\
\text { (rem) }\end{array}$} \\
\hline & $\chi / Q^{\prime}$ & rem & \\
\hline $\begin{array}{l}\text { Onsite } \\
(100 \mathrm{~m}, \mathrm{E})\end{array}$ & $7.32 \mathrm{E}-02$ & $8.7 \mathrm{E}-03$ & 25 to 100 \\
\hline $\begin{array}{l}\text { Columbia River, near bank } \\
(520 \mathrm{~m}, \mathrm{~W})\end{array}$ & $3.55 \mathrm{E}-03$ & $7.0 \mathrm{E}-04$ & -- \\
\hline $\begin{array}{l}100 \text { Area Fire Station } \\
(3,750 \mathrm{~m}, \mathrm{ESE})\end{array}$ & $1.60 \mathrm{E}-04$ & $1.9 \mathrm{E}-05$ & -- \\
\hline $\begin{array}{l}\text { Hanford Site boundary } \\
(10,070 \mathrm{~m}, \mathrm{~W})\end{array}$ & $4.49 \mathrm{E}-05$ & $8.8 \mathrm{E}-06$ & 1 to 25 \\
\hline
\end{tabular}

The source term for the resuspension case is $4.80 \mathrm{E}-04 \mathrm{~mL}$ as given above. The $\chi / \mathrm{Q}^{\prime}$ values are for the assumed 12-hour release duration (see Table 3-2). Calculated doses are given in Table 18. 
Table 3-18. Summary of Dose Consequences for Resuspension of 1-L Sludge Spill.

\begin{tabular}{|l|c|c|c|}
\multicolumn{1}{c|}{$\begin{array}{c}\text { Receptor location } \\
\text { (distance, direction) }\end{array}$} & $\chi / \mathbf{Q}^{\prime}$ & Unmitigated & $\begin{array}{c}\text { Evaluation guidelines } \\
\text { (rem) }\end{array}$ \\
\cline { 2 - 4 } & $6.28 \mathrm{E}-03$ & $2.9 \mathrm{E}-02$ & 25 to 100 \\
\hline $\begin{array}{l}\text { Onsite } \\
(100 \mathrm{~m}, \mathrm{E})\end{array}$ & $2.90 \mathrm{E}-04$ & $2.2 \mathrm{E}-03$ & -- \\
\hline $\begin{array}{l}\text { Columbia River, near bank } \\
(520 \mathrm{~m}, \mathrm{~W})\end{array}$ & $2.73 \mathrm{E}-05$ & $1.3 \mathrm{E}-04$ & -- \\
\hline $\begin{array}{l}100 \text { Area Fire Station } \\
(3,750 \mathrm{~m}, \mathrm{ESE})\end{array}$ & $1.01 \mathrm{E}-05$ & $7.6 \mathrm{E}-05$ & 1 to 25 \\
\hline $\begin{array}{l}\text { Hanford Site boundary } \\
(10,070 \mathrm{~m}, \mathrm{~W})\end{array}$ & & \\
\hline
\end{tabular}

Because the same operator may be exposed to both the 15 -minute splash/splatter dose and the 12-hour resuspension dose, the total dose is shown in Table 3-19.

Table 3-19. Summary of Total Dose Consequences for 1-L Sludge Spill.

\begin{tabular}{|l|l|c|}
\hline \multicolumn{1}{|c|}{$\begin{array}{c}\text { Receptor location } \\
\text { (distance, direction) }\end{array}$} & Unmitigated rem & $\begin{array}{c}\text { Evaluation guidelines } \\
\text { (rem) }\end{array}$ \\
\hline $\begin{array}{l}\text { Onsite } \\
(100 \mathrm{~m}, \mathrm{E})\end{array}$ & $3.8 \mathrm{E}-02$ & 25 to 100 \\
\hline $\begin{array}{l}\text { Columbia River, near bank } \\
(520 \mathrm{~m}, \mathrm{~W})\end{array}$ & $2.9 \mathrm{E}-03$ & -- \\
\hline $\begin{array}{l}100 \mathrm{Area} \text { Fire Station } \\
(3,750 \mathrm{~m}, \mathrm{ESE})\end{array}$ & $1.5 \mathrm{E}-04$ & -- \\
\hline $\begin{array}{l}\text { Hanford Site boundary } \\
(10,070 \mathrm{~m}, \mathrm{~W})\end{array}$ & $8.5 \mathrm{E}-05$ & 1 to 25 \\
\hline
\end{tabular}

The toxicological consequences for the 1-L spill are calculated using Equation 3-4. The acute release $\chi / Q^{\prime}$ is used for both splash/splatter and resuspension. The release rates, as given above, are $1.39 \mathrm{E}-08 \mathrm{~L} / \mathrm{s}$ for splash/splatter and $1.11 \mathrm{E}-08 \mathrm{~L} / \mathrm{s}$ for resuspension, or $2.50 \mathrm{E}-08$ for both. Consequences are shown in Table 3-20.

Table 3-20. Downwind Uranium Concentration for 1-L Sludge Spill.

\begin{tabular}{|l|c|c|c|}
\hline \multicolumn{1}{|c|}{$\begin{array}{c}\text { Receptor location } \\
\text { (distance, direction) }\end{array}$} & $\begin{array}{c}\chi / \mathbf{Q}^{\prime} \\
\left(\mathbf{s} / \mathbf{m}^{\mathbf{3}}\right)\end{array}$ & $\begin{array}{c}\text { Concentration } \\
\left(\mathbf{m g} / \mathbf{m}^{\mathbf{3}}\right)\end{array}$ & $\begin{array}{c}\text { Evaluation guidelines } \\
\left(\mathbf{m g} / \mathbf{m}^{\mathbf{3}}\right)\end{array}$ \\
\hline $\begin{array}{l}\text { Onsite } \\
(100 \mathrm{~m}, \mathrm{E})\end{array}$ & $7.32 \mathrm{E}-02$ & $2.9 \mathrm{E}-03$ & $\begin{array}{c}1 \text { to } 10 \\
\text { (EPRG-2 to EPRG-3) }\end{array}$ \\
\hline $\begin{array}{l}\text { Columbia River, near bank } \\
(520 \mathrm{~m}, \mathrm{~W})\end{array}$ & $3.55 \mathrm{E}-03$ & $1.4 \mathrm{E}-04$ & - \\
\hline $\begin{array}{l}100 \mathrm{Area} \text { Fire station } \\
(3,750 \mathrm{~m}, \mathrm{ESE})\end{array}$ & $1.60 \mathrm{E}-04$ & $6.4 \mathrm{E}-06$ & - \\
\hline $\begin{array}{l}\text { Hanford Site boundary } \\
(10,070 \mathrm{~m}, \mathrm{~W})\end{array}$ & $4.49 \mathrm{E}-05$ & $1.8 \mathrm{E}-06$ & $\begin{array}{c}0.6 \text { to } 1 \\
\text { (EPRG-1 to EPRG-2) }\end{array}$ \\
\hline
\end{tabular}




\subsubsection{Comparison to Guidelines}

For the 500-L spill, the radiological doses and toxicological concentrations are well within the "low" consequence bin at all receptor locations.

For the 1-L spill, all consequences are also well within the "low" guidelines. For the consequences of this spill to approach "moderate" guidelines, the spill volume would have to be increased to $300 \mathrm{~L}$. In this case, the onsite concentration would be approximately $1 \mathrm{mg} / \mathrm{m}^{3}$. It is not credible that a spill of this magnitude would remain unnoticed. Any credible unnoticed spill would not challenge guidelines.

\subsubsection{Summary of Safety Structures, Systems, and Components and Technical Safety Requirement Controls}

Because the consequences do not challenge risk guidelines, no SSCs or TSR controls are required to mitigate the sludge spill accident. However, the sludge retrieval and shipment preparation controls described in Section 3.4.1.6 are required to protect the source term assumptions used in the analysis.

\subsubsection{High Chemical Reaction Rate in LDC}

Small amounts of uranium metal are present in $\mathrm{K}$ Basin sludge. Nominal and bounding estimates for $\mathrm{KE}$ canister sludge are $2.1 \mathrm{wt} \%$ and $5 \mathrm{wt} \%$, respectively, while nominal and bounding estimates for $\mathrm{KE}$ floor sludge are $0.26 \mathrm{wt} \%$ and $1.5 \mathrm{wt} \%$, respectively

(HNF-SD-SNF-TI-015, Volume 2). The volume ratio of floor to canister sludge was analyzed in SNF-10293 based on sludge height and areal measurements made in 1994. Based on this analysis, it was determined that any batch $\left(0.5 \mathrm{~m}^{3}\right)$ of sludge could conservatively be represented by a 60:40 floor to canister sludge volume percent ratio.

Uranium metal reacts exothermically with water to produce uranium oxide and hydrogen gas. The reaction rate is a function of temperature. At normal ambient temperatures, the reaction proceeds slowly and the heat is dissipated and hydrogen is released. As the sludge temperature rises, the reaction rate increases. In the context of this analysis, a high chemical reaction rate means a reaction rate higher than that analyzed as safe. The approach taken here has been to establish a sludge payload that is safe even under extreme conditions, both in terms of sludge properties and environmental conditions. Conditions under which the sludge temperature reaches $100^{\circ} \mathrm{C}$ or the vessel is overpressurized are deemed unsafe. These unsafe conditions are then avoided with appropriate design and administrative controls (AC).

Behavior of Uniformly Mixed Sludge. The temperature in a LDC can be raised by both internal and external means. Internal energy sources include radioactive decay heat and chemical heat from the uranium metal-water reaction. External energy sources include a high ambient temperature, solar radiation, and fire. The rate at which the exothermic reaction of uranium metal and water takes place is provided in HNF-SD-SNF-TI-015, Volume 1, Spent Nuclear Fuel Project Technical Databook, Table 4-4, as

$$
\mathrm{R}=\mathrm{A}_{\mathrm{s}} \xi \mathrm{k}
$$


where " $\mathrm{A}_{\mathrm{s}}$ " is the total reactive surface area of the uranium metal in $\mathrm{K}$ Basin sludge. The enhancement factor, " $\xi$," is a conservative factor to account for potential uncertainties. It has a value of 3 according to HNF-SD-SNF-TI-015, Volume 2. The metal-water reaction rate per unit surface area, "k," increases exponentially with temperature according to the equations given in HND-SD-SNF-TI-015, Volume 1, Table 4-4. For the reaction of uranium metal with water below boiling, the rate of oxygen consumption is given by

$$
\mathrm{k}=10^{7.634-3016 / \mathrm{T}} \frac{\mathrm{mg}}{\mathrm{hr} \cdot \mathrm{cm}^{2}}
$$

where " $\mathrm{T}$ " is temperature in Kelvin. For example, the oxygen consumption rate at $25^{\circ} \mathrm{C}\left(77^{\circ} \mathrm{F}\right)$, which is the controlled maximum temperature in the KE Basin, is calculated to be

$$
\mathrm{k}=10^{7.634-3016 / 298}=3.26 \mathrm{E}-03 \frac{\mathrm{mg}}{\mathrm{hr} \cdot \mathrm{cm}^{2}}
$$

According to SNF-9955, Safety-Basis Thermal Analysis for KE Basin Sludge Transport and Storage, the uranium metal inventory in a LDC payload of $2 \mathrm{~m}^{3}$ of $60: 40$ floor-to-canister sludge is initially $127 \mathrm{~kg}$. The reactive surface area of the uranium metal in $\mathrm{K}$ Basin sludge is $6.32 \mathrm{~cm}^{2} / \mathrm{g}$ uranium metal. This is equivalent to a sphere with a diameter of $500 \mu \mathrm{m}$ (HNF-SD-SNF-TI-015, Volume 1, Table 4-5a). Substituting these values and an enhancement factor of 3 into Equation 3-9 yields.

$$
\mathrm{R}=(127 \mathrm{~kg})\left(6320 \frac{\mathrm{cm}^{2}}{\mathrm{~kg}}\right)(3)\left(3.26 \mathrm{E}-03 \frac{\mathrm{mg}}{\mathrm{hr} \cdot \mathrm{cm}^{2}}\right)=7.84 \mathrm{E}+03 \frac{\mathrm{mg}}{\mathrm{hr}}
$$

Thus the molar production of hydrogen is $0.49 \mathrm{~g}-\mathrm{mole} / \mathrm{h}(12 \mathrm{~L} / \mathrm{hr})$ at $25^{\circ} \mathrm{C}$. For comparison purposes, the radiolytic hydrogen production rate in a safety basis LDC is $0.028 \mathrm{~g}-\mathrm{mole} / \mathrm{h}$ (SNF-9955). This value is also supported in Attachment 14 of SNF-18133, Gas Behavior in Large Diameter Containers (LDCS) During and Following Loading With $105 \mathrm{~K}$ East Sludge, for the Modified Safety Basis Case.

According to HNF-SD-TP-SARP-017, Safety Analysis Report for Packaging (Onsite) Multicanister Overpack Cask, the heat of reaction is $533.3 \mathrm{~kJ} / \mathrm{g}$-mole- $\mathrm{U}$, therefore, the chemical reaction energy production rate in a safety basis $\mathrm{LDC}$ at $25^{\circ} \mathrm{C}$ is

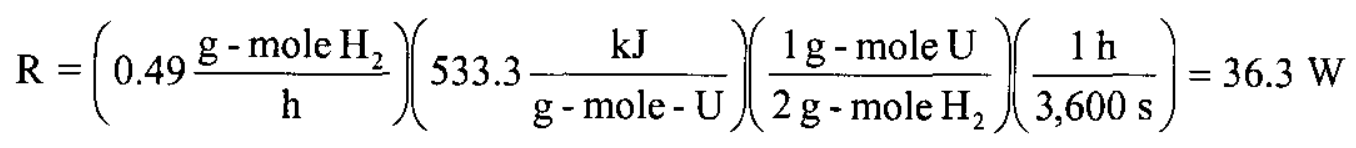

For comparison purposes, the radiolytic decay heat production in a safety basis LDC is $88 \mathrm{~W}$ (HNF-SD-SNF-TI-015, Volume 2).

Segregation of Uranium Metal During Sludge Retrieval. Some segregation of uranium metal particles is expected during sludge retrieval and transport. HNF-10280, FAI/02-08 - Sludge Settling and Segregation During Loading, and SNF-9955 estimate the potential concentration of uranium metal particles that could be produced within the LDC during sludge retrieval. Since 
uranium metal particles are denser and generally larger than the other particles in the sludge (e.g., uranium oxide, sand), it is expected that metal particles will fall more rapidly to the bottom of the vessel forming a more highly concentrated layer of uranium metal. This concentrates the heat generation causing higher local temperatures, which further accelerates the reaction.

Thermal and gas generation analyses of sludge under extreme transport conditions have been performed using a detailed computational fluid dynamics model that accounts for a temperature distribution within the sludge. Earlier computational fluid dynamics models assumed all of the uranium metal and oxide segregated to the bottom of the LDC ( $50 \mathrm{wt} \%$ uranium metal). Thermal results indicated that in this case local sludge temperatures could reach boiling due to self-heating, which was unacceptable. In order to avoid this condition, sludge retrieval controls were formulated such that a LDC could be filled in no fewer than four batches over a specified interval of time. This would allow the lower density sludge material to settle out in between the uranium metal layers. A particle settling and segregation model was developed (HNF-10280) to help predict the depths and characteristics of these layers. Results of these studies indicated that four $0.5-\mathrm{m}^{3}$ batches, with appropriate time for settling between them, would yield alternating layers of denser sludge and lighter sludge particulates with a uranium metal concentration profile that could be represented conservatively by a constant value of $10 \mathrm{wt} \%$. This is double the peak expected value for pure canister sludge. The layers predicted by this model were later verified by laboratory experiments with sludge simulant as reported in PNNL-13854, Settling Test Using Simulant to Emulate Uranium Metal Distribution in K Basin Sludge.

\subsubsection{Scenario Development}

As identified in SNF-10020, there are several means by which the reaction could progress at a rate faster than expected:

- Strainer fails allowing metal fuel pieces to be retrieved into LDC,

- Too much sludge retrieved in a single LDC,

- Denser uranium metal particles become segregated into a more compact layer creating conditions favoring local heating and accelerated reaction rate.

Localized boiling potentially could occur if not prevented through controls. Localized boiling could be a precursor to plugging the vent filter on the LDC (installed after sludge retrieval) resulting in pressurization of the LDC. A higher than expected reaction rate could also result in the cask pressure exceeding its design pressure sooner than expected. The ultimate consequences of such unmitigated events are represented by an overpressurization or hydrogen burn event either in the LDC or the cask, depending on the configuration at the time (i.e., LDC isolated and vent filter plugged with cask lid off, or LDC vented to sealed cask). Specific scenarios are developed in Sections 3.4.4, 3.4.5, 3.4.6 and 3.4.7 to address these hazards.

\subsubsection{Source Term Analysis}

See Sections 3.4.4, 3.4.5, 3.4.6 and 3.4.7 for development of source terms representing the hazard of a higher than expected uranium metal-water reaction rate. 


\subsubsection{Consequence Analysis}

The ultimate consequences, of a higher than expected uranium metal-water reaction rate, are an overpressurization or hydrogen burn involving either the LDC or cask. See Sections 3.4.4, 3.4.5, 3.4.6, and 3.4.7 for further details on the development of these consequences.

\subsubsection{Comparison to Guidelines}

See Sections 3.4.4, 3.4.5, 3.4.6, and 3.4.7 for a comparison of relevant consequences to the evaluation guidelines.

\subsubsection{Summary of Safety Structures, Systems, and Components and Technical Safety Requirement Controls}

To provide a safe sludge payload, the TSR-level sludge retrieval and shipment preparation administrative controls apply to both pit sludge and canister-floor sludge. The following controls are proposed for this accident:

- Sludge strainer baskets shall be in place at all times during sludge loading of the LDC. This control is needed to protect the sludge composition assumed in the analysis.

- Basin water temperature shall be less than or equal to $25^{\circ} \mathrm{C}$. The basin temperature control is necessary to ensure that reaction rates progress at a rate enveloped by the safety analysis.

- LDC shall be loaded in batches less than or equal to $0.5 \mathrm{~m}^{3}$ with an appropriate settling time between batches as described in Section 3.4.1.6. This control is needed to protect the sludge composition assumed in the analysis.

- For canister-floor sludge, each $0.5 \mathrm{~m}^{3}$ batch shall consist of both canister sludge and its associated floor sludge (to preserve the 60:40 mixture basis) as described in Section 3.4.1.6. This control is needed to protect the sludge composition assumed in the analysis.

- The maximum as-settled sludge payload in an LDC shall be less than or equal to $2 \mathrm{~m}^{3}$. The payload limit of $2 \mathrm{~m}^{3}$ is necessary to ensure that sufficient void space remains in the container to accommodate expansion of the sludge due to uranium metal corrosion, hydration of oxides, and gas retention without causing the water layer on top of the sludge to reach the top of the container. The $2 \mathrm{~m}^{3}$ payload is also an analysis assumption in the evaluation of sludge thermal and gas behavior during staging and transport. Exceeding this payload limit would invalidate the assumption as well as cause the potential for sludge or contaminated water to overflow the container during staging, transport, or storage. Bulk particulate entering the LDC vent and vent filter could be a precursor to container overpressurization.

- LDC free volume is at least $1.2 \mathrm{~m}^{3}$. This control is needed to protect the cask/LDC volume assumed in the analysis. 
- A vent path must exist between the LDC and the cask annulus after the LDC is disconnected from the SWS. This control is needed to protect the cask/LDC volume assumed in the analysis.

- Strainer bypass valves shall be verified closed to prevent bypassing the strainer. This control is needed to protect the sludge composition assumed in the analysis.

In addition to the above ACs, the following design features are credited.

- LDC - The LDC is a pressure vessel designed to the standards of Section VIII of the Boiler and Pressure Vessel Code (ASME 1998). It is rated for $150 \mathrm{lb} / \mathrm{in}^{2}$ gauge. This rating provides some assurance that the LDC will perform a confinement function with a bounding normal payload even after several days of extreme off-normal conditions. The LDC pressure boundary is considered safety significant because of its confinement function during sludge retrieval and preparation for shipping. The safety function is to provide confinement during sludge retrieval and preparation for shipping.

- LDC inlet deflector plate - The deflector plate provides lateral uniformity of the heavier uranium metal particles within the retrieved sludge layers. Failure of the deflector plate could cause bulk mixing and segregation of the sludge layers to a greater degree than that analyzed. The LDC inlet deflector plate performs a safetysignificant function by ensuring sufficient uniformity of uranium metal particulates contained within the retrieved sludge. Failure of the deflector plate would result in a lack of lateral distribution of the heavier uranium metal particulates and turbulent mixing or segregation of the previously retrieved sludge layers. This could cause a concentrated layer or pile of uranium metal and a high local reaction rate within the LDC during staging, transport, or storage. This condition could lead to localized boiling or higher than expected hydrogen gas generation and ultimately lead to a LDC-cask overpressurization event or hydrogen deflagration. The plate must be of sufficient diameter and distance from the inlet nozzle to create the velocity necessary to disperse the heavier uranium metal particulates contained in the sludge. The plate must also withstand the forces of impingement and erosion without failure during its service life.

- Sludge strainer basket - In addition to the obvious need to prevent large particles from entering the pump, the sludge strainer basket (and associated support diaphragm) provides the additional safety function of ensuring that the safety basis analysis envelope is protected by allowing only sludge to enter the container. Particles that would not pass through a $0.25 \mathrm{in}$. mesh were not included in the characterization of sludge and were not analyzed as a portion of the container payload.

\subsubsection{Cask Overpressurization}

The hazards that are covered by this bounding unmitigated accident are intended to represent all possible high-pressure events for the cask. In particular, the following hazards were identified in SNF-10020: 
- High cask pressure due to excess hydrogen accumulation during staging and transport,

- Fire,

- High argon purge pressure.

The scenario developed here represents a bounding overpressurization event whether it is caused by high argon purge pressure or hydrogen accumulation. Fire events are covered in Sections 3.4.8 and 3.4.9.

\subsubsection{Scenario Development}

The sludge transportation cask is designed in accordance with the ASME, Boiler and Pressure Vessel Code, Section III (ASME 1998), with a design pressure of $80 \mathrm{lb} / \mathrm{in}^{2}$ gauge. It is hydrotested to $120 \mathrm{lb} / \mathrm{in}^{2}$ gauge. As indicated in Table 3-17, the ultimate pressure within the cask due to $100 \%$ reaction of the uranium metal with water is about $79 \mathrm{lb} / \mathrm{in}^{2}$ gauge; therefore catastrophic structural failure from hydrogen accumulation would be limited to lid seal damage.

Since the normal argon supply during the staging of the closed cask for shipment is dispensed from large high-pressure storage cylinders, overpressurization of the cask could also occur due to failure of pressure regulation in the active inert ventilation system during preparations for shipping. This event could occur while the AIVS is providing an argon purge through the drain plug fitting after cask closure in the event of closure of the cask vent. The normal argon supply to the active inert ventilation system passes through two pressure reducers before reaching the cask. Cylinder pressure is reduced to 425 psig by PRV-507 and then to 30 psig by PRV- 501 . The second pressure reducer (SPR) and a pressure relief valve (SRV-501) on the $30 \mathrm{psig}$ header would have to fail in order to expose the cask to an overpressure condition from 425 psig argon. Such an overpressure condition could cause a failure of the cask seal or of some other part of the pressure boundary leading to sudden depressurization of the LDC. No credit is taken for the vent filters on the LDC since they could fail in such an event. The resulting venting of the LDC would produce the same type of release from inside the LDC as the overpressure failure of the LDC analyzed in Section 3.4.5, but to a lesser degree.

\subsubsection{Source Term Analysis}

The release from the LDC into the cask due to a depressurization of the cask is the same type of release analyzed in Section 3.4.5.2 for the container overpressure scenario, i.e., the venting gas would sweep material from the filters inside the LDC and out through the vent filter fittings on the LDC. Since the LDC is vented, the cask and LDC are assumed to be at equilibrium prior to the accident so that it makes no difference whether the overpressure condition is caused by gas accumulation from the sludge or by a pressure regulation failure in the AIVS.

When the cask vents, the vent filters on the LDC are assumed to fail and all of the material released from the LDC is assumed to exit through the pressure boundary opening in the cask system. It is expected that this release would be less than (i.e., would be bounded by) the 270 -g release developed for the LDC overpressurization accident in Section 3.4 .5 because (1) the cask system (design pressure $=80 \mathrm{psig}$ ) would be expected to fail at a lower pressure than the LDC 
system (design pressure $=150 \mathrm{psig}$ ) and (2) some of the material would be expected to remain in the volume between the LDC and the cask.

\subsubsection{Consequence Analysis}

The dose consequences of a cask overpressure and catastrophic failure event are bounded by the LDC overpressurization analyzed in Section 3.4.5.

\subsubsection{Comparison to Guidelines}

Onsite consequences could challenge the 100-rem threshold for a high-consequence event. The consequences at the site boundary, however, are well within the low consequence range. Serious injuries to workers in close proximity to the cask are also a possibility.

\subsubsection{Summary of Safety Structures, Systems, and Components and Technical Safety Requirement Controls}

To ensure the rate of cask pressure rise remains within analyzed limits the following TSR controls are proposed.

- Administratively control sludge retrieval and shipment preparation as specified in Section 3.4.3.5. This protects source term assumptions used in the analysis.

- Maintain building doors closed (see Section 3.4.7.6).

In addition to the above TSR controls, the following SSCs are important to safety.

- The AIVS safety relief valve (SRV-501) protects against overpressurization of both the AIVS and the cask in the event of a failure of the argon pressure regulator.

- The LDC inlet deflector plate as described in Section 3.4.3.5. The deflector plate protects the analysis assumption of sludge content.

- The strainer basket as described in section 3.4.3.5. The strainer basket protects the analysis assumption of sludge content.

- The cask is designed in accordance with Section III of ASME (1998), with a design pressure of $80 \mathrm{lb} / \mathrm{in}^{2}$ gauge. The safety function of the cask is to provide containment during normal and accident conditions.

\subsubsection{LDC Overpressurization}

The hazard evaluated in this bounding unmitigated accident specifically represents a high pressure venting from the LDC while the cask lid is not in place. The most probable cause of an overpressurization in the LDC is excess hydrogen generation due to the uranium metal-water reaction while the LDC is isolated. An overpressurization of the LDC could also be caused by a series of malfunctions in the active inert ventilation system while the LDC is otherwise isolated. Several events could cause isolation of the LDC, such as having an argon vent valve stuck closed 
after pump shutdown or having a plugged vent filter after sludge retrieval. A plugged vent filter could be the result of material incompatibility, sludge overfill, or sludge making its way to the top of the LDC. The LDC could also overpressurize if a blank is inadvertently installed in place of the vent filter.

\subsubsection{Scenario Development}

This non-mechanistic overpressurization event is intended to conservatively represent the hazardous material release from any sudden venting of the LDC. As such, engineering judgment is used to identify a bounding yet reasonable scenario. The major phenomenon that can cause high pressure is the uranium metal-water reaction that produces hydrogen. The thermal sources are the decay heat of radionuclides, hot ambient conditions exterior to the LDC and cask, and the exothermic metal-water reaction. An overpressurization from this source could occur during sludge retrieval or sludge staging. During sludge retrieval the scenario would entail a pump shutdown and isolation of the slurry retrieval and overflow lines. The vent valve would either be closed due to the high water level in the LDC, or the vent line would be isolated via the solenoid valve downstream of the vent valve. Overpressurization of the LDC in this mode would require failure of the pressure relief valve (SRV-402) on the filtered water return to basin line. During sludge staging the LDC is already disconnected from the slurry retrieval, overflow, and LDC vent lines. The discharge of SRV-402 is routed to a safe location such that aerosols would not be released directly into the environment. The cask is assumed to be open, with no lid or with the lid not bolted down. Once filled and prior to installation of the cask lid the LDC is fitted with a HEPA-type vent filter and a rupture disk that is designed to open at $50 \mathrm{lb} / \mathrm{in}^{2}$ gauge.

Overpressurization during this short interval would require a plugged or inoperable vent filter. Actuation of the rupture disk could cause a direct release of sludge aerosols into the environment.

Since the normal argon supply is dispensed from large high-pressure storage cylinders, overpressurization of the LDC could also occur due to failure of pressure regulation in the active inert ventilation system. This event could occur any time after the active inert ventilation system is turned on to form the initial argon bubble at the top of the LDC until it is disconnected from the LDC in preparation for cask closure. As with the hydrogen build-up case, the LDC would have to be isolated and the pressure relief valve (SRV-402) would have to fail. The normal argon supply to the active inert ventilation system passes through three pressure reducers before reaching the LDC. Cylinder pressure is reduced to 425 psig by PRV-507, then to 30 psig by PRV-501, and finally to 4 psig by PRV-505. The last two pressure reducers and an additional pressure relief valve (SRV-501) on the 30 psig header would have to fail in order to expose the LDC to an overpressure condition from 425 psig argon.

In either of these scenarios, the pressurized LDC is assumed to rapidly vent. Depending on the exact scenario and the time of the event, a sudden venting could be caused by the filtered vent blowing out, activation of the rupture disk, or a weld seam failing at a pressure well above design. These failures are all assumed to occur on top of the LDC. A weld failure on the bottom or side of the LDC is bounded by a weld failure on top because the LDC is always inside the shipping cask when at the KE basin. The annular gap between the LDC and cask is between 0.5 to 1 inch. A breach of the LDC at the bottom or side is not only less likely but the cask would catch most of the released material through impingement. The release consists of sludge 
entrained in the exiting gases. In summary the buildup of hydrogen or argon gas increases the pressure inside the LDC until one of the components (vent filter, rupture disk, or weld seam) opens or is breached causing the LDC headspace to rapidly vent.

\subsubsection{Source Term Analysis}

The MAR is the sludge that collects on inner surfaces of the LDC during loading at KE Basin. These surfaces, primarily the internal filter assemblies and inner LDC headspace walls, are mostly above the water level in the LDC. The sludge on these surfaces is expected to be wet because the bottoms of the filters are below water. According to ER-3C-0126-02, K-East Basin Sludge Transport System - Large Container: Proof of Principle Test Report dated 1/17/02, the wet volume of sludge left on the filters without any backflushing was measured (using a sludge simulant) to be about $400 \mathrm{lb}\left(1.8 \times 10^{5} \mathrm{~g}\right)$. When the LDC vents at high pressure, some of the wet sludge is entrained by the flowing gas (argon, water vapor and hydrogen) and is carried out through the opening created on the top of the LDC by the blown vent or rupture disk or by the weld failure.

The release is conservatively modeled as blast flow across dry material on the LDC internal filters. Appropriate ARF and RF values for this type of release are identified in DOE-HDBK-3010-94, Section 4.4.2.2.2. The recommended bounding values are 5.0E-03 and 0.3 for the ARF and RF, respectively. The respirable release source term is calculated below using Equation 3-1.

$$
\mathrm{Q}=\left(1.8 \times 10^{5} \mathrm{~g}\right) \times 5 \times 10^{-3} \times 0.3=270 \mathrm{~g}
$$

Use of this value is conservative, as it does not consider the fact that the majority of the MAR will likely be trapped within the internal filters rather than on the exterior surface of the filters, and that the sludge coating the internal filters will likely be wet due to the recent submergence under water and high humidity within the LDC. Intuitively, wet sludge material would be much more difficult to entrain than dry powder. The above source term is also conservative with respect to mechanistic source term calculations documented in HNF-12563, Accident and Thermal Analysis for Handling and Storing K-E Basin Sludge at T Plant. These calculations estimated respirable releases on the order of fractions of a gram for release pressures up to $350 \mathrm{lb} / \mathrm{in}^{2}$ gauge.

\subsubsection{Consequence Analysis}

The dose consequences are calculated using Equation 3-2 with a source term of $270 \mathrm{~g}$ of sludge, an LPF of 1 , and acute release ( $<1$ hour) atmospheric transport factors for each receptor location. The dose consequences are shown in Table 3-21. The evaluation guidelines show the range for a moderate consequence event. Numbers above this range indicates a high consequence while numbers below this range indicate a low consequence. 
Table 3-21. Summary of Maximum Dose Consequences for LDC Overpressurization.

\begin{tabular}{|c|c|c|c|}
\hline \multirow{2}{*}{$\begin{array}{l}\text { Receptor location } \\
\text { (distance, direction) }\end{array}$} & \multicolumn{2}{|c|}{ Unmitigated } & \multirow{2}{*}{$\begin{array}{c}\text { Evaluation guidelines } \\
\text { (rem) }\end{array}$} \\
\hline & $\chi / \mathbf{Q}^{\prime}$ & rem & \\
\hline $\begin{array}{l}\text { Onsite } \\
(100 \mathrm{~m}, \mathrm{E})\end{array}$ & $7.32 \mathrm{E}-02$ & $9.9 \mathrm{E}+01$ & 25 to 100 \\
\hline $\begin{array}{l}\text { Columbia River, near bank } \\
(520 \mathrm{~m}, \mathrm{~W})\end{array}$ & 3.55 E- 03 & $7.9 \mathrm{E}+00$ & -- \\
\hline $\begin{array}{l}100 \text { Area Fire Station } \\
(3,750 \mathrm{~m}, \mathrm{ESE})\end{array}$ & $1.60 \mathrm{E}-04$ & $2.2 \mathrm{E}-01$ & -- \\
\hline $\begin{array}{l}\text { Hanford Site boundary } \\
(10,070 \mathrm{~m}, \mathrm{~W})\end{array}$ & $4.49 \mathrm{E}-05$ & $1.0 \mathrm{E}-01$ & 1 to 25 \\
\hline
\end{tabular}

The toxicological consequences of the release can be calculated using Equation 3-4. Note that the release of $270 \mathrm{~g}$ of sludge with a uranium content of 0.84 is averaged over 15 minutes (as discussed in Section 3.3.3), for a release rate of $0.25 \mathrm{~g} / \mathrm{s}$. Results are shown in Table 3-22.

Table 3-22. Downwind Uranium Concentration for LDC Overpressurization.

\begin{tabular}{|l|c|c|c|}
\hline \multicolumn{1}{|c|}{$\begin{array}{c}\text { Receptor location } \\
\text { (distance, direction) }\end{array}$} & $\begin{array}{c}\boldsymbol{\alpha} / \mathbf{Q}^{\prime} \\
\left(\mathbf{s} / \mathbf{m}^{\mathbf{3}}\right)\end{array}$ & $\begin{array}{c}\text { Concentration } \\
\left(\mathbf{m g} / \mathbf{m}^{\mathbf{3}}\right)\end{array}$ & $\begin{array}{c}\text { Evaluation guidelines } \\
\left(\mathbf{m g} / \mathbf{m}^{\mathbf{3}}\right)\end{array}$ \\
\hline $\begin{array}{l}\text { Onsite } \\
(100 \mathrm{~m}, \mathrm{E})\end{array}$ & $7.32 \mathrm{E}-02$ & $1.8 \mathrm{E}+01$ & 1 to 10 \\
\hline $\begin{array}{l}\text { Columbia River, near bank } \\
(520 \mathrm{~m}, \mathrm{~W})\end{array}$ & $3.55 \mathrm{E}-03$ & $8.9 \mathrm{E}-01$ & -- \\
\hline $\begin{array}{l}100 \text { Area Fire station } \\
(3,750 \mathrm{~m}, \mathrm{ESE})\end{array}$ & $1.60 \mathrm{E}-04$ & $4.0 \mathrm{E}-02$ & -- \\
\hline $\begin{array}{l}\text { Hanford Site boundary } \\
(10,070 \mathrm{~m}, \mathrm{~W})\end{array}$ & $4.49 \mathrm{E}-05$ & $1.1 \mathrm{E}-02$ & 0.6 to 1 \\
\hline
\end{tabular}

\subsubsection{Comparison to Guidelines}

Onsite consequences could challenge the 100-rem threshold for a high-consequence event. The consequences at the site boundary, however, are well within the low consequence range. Serious injuries to workers in close proximity to the cask are also a possibility.

The first mitigator is the leak path factor (LPF) of the building. The accident analyzed occurs within the K Basins building. The leak path factor is taken from HNF-1777, $K$ West Basin Integrated Water Treatment System Annular Filter Vessel Accident Calculation and Derivation of Leak Path Factor. This report presents the result of a 2-D FLUENT analysis of the K Basin facility. The FLUENT code is a finite-element fluid dynamics and heat transfer code. The facility model included fans in the ceiling of the transfer bay and four fans above the basin. Air was assumed to infiltrate from the east and west sides of the facility through gaps between the doors and the frame, and other inlet openings. The doors of the facility are assumed to be closed. The water surface of the basins is included in the model. Initial particle release location in the model is near the annular filters (which are close to where the LDC would be located if the 
analysis had been done for the KE facility). Respirable particle sizes of $0.44 \mu \mathrm{m}, 1 \mu \mathrm{m}$, and $4.4 \mu \mathrm{m}$ were modeled. The LPF was calculated to be 0.5. See Section 3.4.7.5 for further discussion.

Using this LPF, the doses are:

Onsite: $\quad 50 \mathrm{rem}$

Offsite: $\quad 0.05 \mathrm{rem}$.

The mitigated frequency is Anticipated. The mitigated risk bins are:

$\begin{array}{ll}\text { Onsite: } & \text { I } \\ \text { Offsite: } & \text { III }\end{array}$

Further mitigation is required. The presence of relief valve SRV-402 will reduce the frequency to Unlikely. The mitigated risk bin with the LPF and Unlikely frequency is II.

In addition to the LPF, two other factors, for which credit is not specifically taken, can reduce the dose. The first of these involves $\chi / Q^{\prime}$. The release is carried out of the buildings via the fans, so that the release extends the entire length of the building and is no longer a point source. The fans also provide some momentum to the release out the roof. The $\chi / \mathrm{Q}^{\prime}$ for the intact building case of the Detonation in a Pressurized LDC in Section 3.4 .7 is $8.1 \mathrm{E}-03 \mathrm{~s} / \mathrm{m}^{3}$. In that case, the release is blown out of the cracks and gaps in the walls and ceilings. This case where the release is drawn out of the facility by the fans has a similar release path and momentum. As a result, the $\chi / \mathrm{Q}^{\prime}$ could be as much as a factor of 9 less because:

$$
\frac{\text { Point Source } / Q}{\text { AreaSource } / Q}=\frac{7.32 E-02 \mathrm{~s} / \mathrm{m}^{3}}{8.1 E-03 \mathrm{~s} / \mathrm{m}^{3}}=9
$$

The loading on the sludge filters was bounded by $181 \mathrm{~kg}$. A more reasonable loading is $91 \mathrm{~kg}$, as shown in Proof of Principle (POP) Tests POP-1 (ER-3C-0126-02, KE Basin Sludge Transport System - Large Diameter Container: Proof of Principle Test Report) and POP-2 (ER-3C-012604, KE Basin Sludge Transport System - Large Diameter Container: Proof of Principle Test \#2).

Use of this loading will decrease the doses by a factor of 2 .

\subsubsection{Summary of Safety Structures, Systems, and Components and Technical Safety Requirement Controls}

The following safety-significant SSCs are required:

- LDC pressure boundary as described in Section 3.4.3.5. The analysis assumes the LDC does not rupture until the design pressure is reached.

- LDC inlet deflector plate as described in Section 3.4.3.5. The deflector plate protects the analysis assumption of sludge content.

- LDC internal filter assembly - The LDC internal filter assembly performs a safetysignificant function by disrupting sludge being pushed into the upper head space of the 
LDC by a gas-generating layer below it. Such a phenomenon has been observed in small-scale experimental studies and with K Basin sludge samples contained in 3-in.diameter graduated cylinders. It is believed that such a phenomenon, if unmitigated, could cause the LDC vent path to plug with sludge and result in a subsequent overpressurization event. In order to perform its safety function, the filter assembly must be able to withstand the force of the rising slug without deformation so that sludge retrieval through the LDC access port is not jeopardized. The filter assembly must also cause breakup of the slug prior to particulate matter coming into contact with the LDC vent path, which could cause it to plug.

- Strainer basket as described in Section 3.4.3.5. The strainer basket protects the analysis assumption of sludge content.

- LDC vent path - The LDC vent path performs a safety-significant function by allowing gas to exit the LDC and allow inert gas to enter the LDC during inerting, thus precluding a pressure buildup.

- Sludge Retrieval System pressure relief device - The safety function of the Sludge Retrieval System pressure relief device (SRV-402) is to vent pressure buildup (due to hydrogen generation or argon overpressure) from the LDC when the system is isolated and the float valve is closed.

TSR controls are required as follows:

- Maintain building doors closed (see Section 3.4.7.6).

- Sludge retrieval and shipment preparation administrative controls as specified in Section 3.4.3.5. This protects source term assumptions used in the analysis.

\subsubsection{Hydrogen Burn in Cask}

This section presents the consequence of a hydrogen burn within the cask while in the $\mathrm{K}$ Basin structure.

The hazards in the Hydrogen Burn category can be grouped as follows:

1. Hydrogen burns within the cask. This event occurs if the cask is not filled with argon (or if there is air ingress into the cask), cask transport is delayed a period of time necessary for hydrogen to build to flammable levels within the cask and is ignited possibly by the drain port tool. The event could also occur if the cask is purged with argon.

2. Hydrogen burn outside of the cask if a long period of time elapses between the placement of the cask lid and cask purging with argon. During this time hydrogen can flow from the LDC into the cask. Installation of the tool into the drain or vent port could allow hydrogen to escape, followed by ignition outside of the cask. 
The worst-case event is the first. The second accident results in a flare or fireball but no release. The second is a worker safety issue.

\subsubsection{Scenario Development}

Gas generation is discussed in Section 3.4.7.

The LDC is filled with $2 \mathrm{~m}^{3}$ of sludge. The cask lid is placed on the cask. The cask is either purged with a gas other than argon or the cask is purged with argon but an opening occurs which allows a large quantity of air to enter the cask and LDC. It is assumed that the cask is not transported immediately. Hydrogen accumulates in the cask to the point that the mixture is flammable. Ignition is assumed to occur.

\subsubsection{Source Term Analysis}

The open volume of the cask is $1.2 \mathrm{~m}^{3}$. The minimum open volume of the LDC is assumed to be $1.2 \mathrm{~m}^{3}$. The hydrogen generation is assumed to be the same as that discussed in Section 3.4.7. Section 3.4.7 shows that there is no net oxygen accumulation in the headspace due to chemical reactions taking place between the oxygen dissolved in the liquid and that produced by radiolysis and uranium metal and uranium dioxide. The only oxygen in the headspace is that from the inadvertent use of air instead of argon or that from in-leakage.

Assume that the hydrogen mole fraction in the cask and LDC is 0.3 , the mole fraction that creates the largest energy release when ignited. Assume that the cask is pressurized to $20 \mathrm{psig}$ (a bounding value based on an intended pressurization of $15 \mathrm{psig}$ ) and that the headspace atmosphere is air (not argon). The source term and consequence analysis will follow that provided in Section 3.4.7.2 and 3.4.7.3, as the phenomena are the same.

There are few ignition sources in the cask. The only potential ignition sources are when the drain or vent plug is opened (assuming a friction spark occurs at that time) or if the LDC strikes the cask during movement or seismic event.

Assume that the gas mix in the cask is ignited. Based on the discussion in Section 3.4.7.2, a detonation will not occur in the cask. The fact that the cask pressure is greater than that considered in Section 3.4.7.2 does not change the conclusion. The cask volume and the obstacle field within the cask are too small for a transition to a detonation to occur. A deflagration in the cask, however, could occur if a spark source is present.

Assume that a deflagration occurs within the cask. The next concern is if the flame passes into the LDC. Report AD-A015 822, Design Criteria for Flame Control Devices for Cargo Venting Systems, page 29, equation 25 provides an equation for the minimum length of a flame arrester. The equation is:

$$
\mathrm{L}=2 \mathrm{~S}_{\mathrm{t}} \mathrm{D}_{\mathrm{h}}^{2}
$$

Where $S_{t}=$ turbulent flame velocity, $\mathrm{m} / \mathrm{s}$ (typically $200-500 \mathrm{~m} / \mathrm{s}$ for energetic burns with stoichiometric hydrogen - air mixture) 


$$
\begin{aligned}
D_{h}= & \text { pore diameter, } m \\
= & \text { the pore size if the flame path is through a sintered metal, metal foam or } \\
& \text { wire pack channel (like a filter). Typically the pore size for filters of this } \\
& \text { type is a few microns }\left(10^{-6} \mathrm{~m}\right) . \\
L= & \text { minimum length of the flame arrester }
\end{aligned}
$$

It is seen that a sintered metal filter is a good flame arrestor. However the vent filter is not certified for such service and is not likely to withstand the pressure differential between the cask and the LDC. It is therefore assumed that the vent filter blows out and that a turbulent flame enters the LDC.

Moen (1993), Transition to Detonation in Fuel-Air Mixtures, Section 5.4, provides information on jet ignition of fuel clouds. An experiment was performed in which a turbulent jet of hot combustion products was injected into a cloud of explosive mixture. The jet diameter was $40 \mathrm{~mm}$ (1.6 inches). The mixture detonated. However the mixture was an acetylene-oxygen mixture. For an acetylene-air mixture the diameter would have to be $0.15 \mathrm{~m}$. For hydrogen -air mixtures the jet diameter needs to be $0.2 \mathrm{~m}$ in diameter (about 8 inches). Therefore, the jet will not initiate a detonation in the LDC directly.

The detonation can be initiated indirectly, however, because the hot gases entering the LDC at a high speed creates turbulence in the LDC. Section 3.4.7.2 provided a discussion that a fan creating turbulence can result in a detonation. Since the hot gases entering the LDC through both vent filters are more efficient at creating turbulence than a fan is, a detonation is postulated in the LDC. It should be noted that a detonation could only be initiated in the LDC if the mole fraction of hydrogen is about 0.3 and the mole fraction of oxygen is about 0.15 . The detonation in the LDC is assumed to cause catastrophic failure of the LDC. Since the cask design pressure is half of the LDC design pressure and since the cask plus LDC volume is half that of the LDC alone, pressurization of the LDC will cause the cask to pressurize. The resulting cask pressure will be half of the LDC pressure. Since the design pressure is half, pressurizing the cask to half of the LDC pressure should cause the same effect; that is, cask failure. Cask failure will be the lid coming off based on the judgment of a stress analyst with knowledge of the cask analysis.

A deflagration in the LDC, instead of a detonation, could occur if a shorter period of time is waited. The shorter period of time will result in a hydrogen mole fraction within the cask and LDC less than 0.3. A deflagration in the LDC will cause suspended aerosol and reaction products from the LDC to enter the cask. The cask is not expected to fail, but the lid is assumed to lift resulting in a release of all the aerosol from the LDC to the atmosphere.

Therefore, the releases are the same as those in Section 3.4.7.2, or

$10 \mathrm{~kg}$ for the case of deflagration in the cask with detonation in the LDC in a breached facility,

$1.2 \mathrm{~kg}$ for the case of a deflagration in the cask with a detonation in the LDC in an intact facility, or 
$270 \mathrm{~g}$ for the case where there is a deflagration in the cask and LDC.

Because of the increased pressure in the cask and LDC over that assumed in Section 3.4.7, the resulting overpressure is greater. Under other conditions, this could result in greater consequences. It does not, in this case. In both this case (with an initial pressure of $20 \mathrm{psig}$ ) and that in Section 3.4.7 (with an initial pressure of $10 \mathrm{psig}$ ) catastrophic failure of the LDC is assumed. In both cases, $100 \%$ of the sludge on the sludge filters is lofted.

In Section 3.4.7, the worst-case release is assumed to be distributed in a large buoyant plume. The same will occur in this case. However, due to the greater initial pressure, more hydrogen is needed to bring the mole fraction at ignition to 0.3 . Therefore, the energy released is greater. Substituting 20 psig into the spreadsheet in Appendix B, for the 1200L headspace volume case (Case $2 \mathrm{~b}$ of Appendix B) yields an energy release of $2.8 \times 10^{6} \mathrm{cal}$ and a peak pressure of 407 psig. The energy release in Case $2 \mathrm{~b}$ was $2.03 \times 10^{6} \mathrm{cal}$. Using the plume equation in Section 3.4.7, it is found that the plume height in this case is $8 \%$ greater. Following the mathematical manipulations shows that the respirable quantity is also $8 \%$ greater or $6.2 \mathrm{~kg}$. However, later in that section, the respirable release was assumed to have a bounding value of $10 \mathrm{~kg}$. So the greater pressure did not change the assumed respirable release.

\subsubsection{Consequence Analysis}

The doses cannot be calculated with RADIDOSE (DOE/RL-2002-50), as RADIDOSE does not have the ARF and RF for accidents involving $K$ Basin sludge. Instead, the doses will be calculated by hand using the formula and data from RADIDOSE and the release calculated above.

The doses are found using Equation 3-2 and the breathing rate and UD from Section 3.3.2. Table 3-23a provides the dose consequences for the detonation in a breached structure. The $10-\mathrm{kg}$ source term for deflagration/detonation is given above, and the $\chi / \mathrm{Q}$ 's are from Section 3.4.7.

Table 3-23a. Summary of Maximum Dose Consequences for Hydrogen Burn in Cask $30 \%$ Hydrogen in the cask and LDC (detonation in LDC, LDC and Cask fail, breached structure case).

\begin{tabular}{|c|c|c|c|}
\hline \multirow{2}{*}{$\begin{array}{c}\text { Receptor location } \\
\text { (distance, direction) }\end{array}$} & $\chi^{\prime} / \mathbf{Q}^{\prime}$ & Unmitigated & $\begin{array}{c}\text { Evaluation } \\
\text { guidelines } \\
\text { (rem) }\end{array}$ \\
\cline { 2 - 4 } & $1.60 \mathrm{E}-03$ & $8.1 \mathrm{E}+01$ & 25 to 100 \\
\hline $\begin{array}{c}\text { Onsite } \\
(100 \mathrm{~m}, \mathrm{E})\end{array}$ & $4.74 \mathrm{E}-03$ & $3.9 \mathrm{E}+01$ & -- \\
\hline $\begin{array}{c}\text { Columbia River, near bank } \\
(520 \mathrm{~m}, \mathrm{~W})\end{array}$ & $7.17 \mathrm{E}-05$ & $3.6 \mathrm{E}-01$ & -- \\
\hline $\begin{array}{c}100 \mathrm{Area} \text { Fire Station } \\
(3,750 \mathrm{~m}, \mathrm{ESE})\end{array}$ & $2.28 \mathrm{E}-05$ & $1.9 \mathrm{E}-01$ & 1 to 25 \\
\hline $\begin{array}{c}\text { Hanford Site boundary } \\
(10,070 \mathrm{~m}, \mathrm{~W})\end{array}$ & & & \\
\hline
\end{tabular}


Table 3-23b provides the dose consequences for the detonation in an intact structure. The 1.2-kg source term is given above and the $\chi / \mathrm{Q}$ 's for detonation in an intact structure are from Section 3.4.7.

Table 3-23b. Dose Consequences for Hydrogen Burn in Cask $30 \%$ Hydrogen (detonation in LDC, LDC and Cask fail, intact structure case.

\begin{tabular}{|c|c|c|c|}
\hline \multirow{2}{*}{$\begin{array}{c}\text { Receptor location } \\
\text { (distance, direction) }\end{array}$} & $\chi / \mathbf{Q}^{\prime}$ & Unmitigated & $\begin{array}{c}\text { Evaluation } \\
\text { guidelines } \\
\text { (rem) }\end{array}$ \\
\cline { 2 - 4 } & $8.10 \mathrm{E}-03$ & $4.9 \mathrm{E}+01$ & 25 to 100 \\
\hline $\begin{array}{c}\text { Onsite } \\
(100 \mathrm{~m}, \mathrm{E})\end{array}$ & $1.71 \mathrm{E}-03$ & $1.7 \mathrm{E}+01$ & -- \\
\hline $\begin{array}{c}\text { Columbia River, near bank } \\
(520 \mathrm{~m}, \mathrm{~W})\end{array}$ & $9.91 \mathrm{E}-05$ & $6.0 \mathrm{E}-01$ & - \\
\hline $\begin{array}{c}100 \text { Area Fire Station } \\
(3,750 \mathrm{~m}, \mathrm{ESE})\end{array}$ & $1.69 \mathrm{E}-05$ & $1.7 \mathrm{E}-01$ & 1 to 25 \\
\hline $\begin{array}{c}\text { Hanford Site boundary } \\
(10,070 \mathrm{~m}, \mathrm{~W})\end{array}$ & \multicolumn{2}{|c}{} \\
\hline
\end{tabular}

Consequences of a hydrogen deflagration in the cask are found using Equation 3-2, the 270-g source term given above, and the UD and breathing rate from Section 3.2.2. The $\chi / \mathrm{Q}^{\prime}$ is from Section 3.4.7. Consequences are shown in Table 3-24.

Table 3-24. Summary of Maximum Dose Consequences for Hydrogen Burn in Cask $15 \%$ Hydrogen in the cask and LDC (deflagration in cask and LDC).

\begin{tabular}{|c|c|c|c|}
\hline \multirow{2}{*}{$\begin{array}{r}\text { Receptor location } \\
\text { (distance, direction) }\end{array}$} & \multicolumn{2}{|c|}{ Unmitigated } & \multirow{2}{*}{$\begin{array}{l}\text { Evaluation } \\
\text { guidelines } \\
\text { (rem) }\end{array}$} \\
\hline & $\chi / Q^{(\text {Note 1) }}$ & rem & \\
\hline $\begin{array}{c}\text { Onsite } \\
(100 \mathrm{~m}, \mathrm{E})\end{array}$ & 7.32 E-02 & $9.9 \mathrm{E}+01$ & 25 to 100 \\
\hline $\begin{array}{l}\text { Columbia River, near bank } \\
(520 \mathrm{~m}, \mathrm{~W})\end{array}$ & $3.55 \mathrm{E}-03$ & $7.9 \mathrm{E}+00$ & -- \\
\hline $\begin{array}{l}100 \text { Area Fire Station } \\
(3,750 \mathrm{~m}, \mathrm{ESE})\end{array}$ & $1.60 \mathrm{E}-04$ & $2.2 \mathrm{E}-01$ & - \\
\hline $\begin{array}{l}\text { Hanford Site boundary } \\
(10,070 \mathrm{~m}, \mathrm{~W})\end{array}$ & $4.49 \mathrm{E}-05$ & $1.0 \mathrm{E}-01$ & 1 to 25 \\
\hline
\end{tabular}

The worst case onsite dose is from the deflagration case. In this case the LDC remains intact. This means that there is no plume expansion as a result of the energy liberated as is the case when the LDC and cask fail. Use of point-source models results in much larger values for $\chi / Q^{\prime}$.

The worst case offsite dose comes from the "detonation in the LDC" in a breached structure. The offsite $\chi / \mathrm{Q}^{\prime}$ is similar for all cases. Therefore, the case with the largest respirable release will produce the greatest dose. This is the "detonation in the LDC" in a breached structure case. 


\subsubsection{Comparison to Guidelines}

The offsite doses for the detonation cases are in the dose region where safety class controls must be considered ( 1 to 25 rem offsite). It is judged that no safety class designation need be made due to a number of conservatisms in the consequence analysis. They are:

- The analysis assumptions (use of 60:40 sludge, ignition at 30\% hydrogen in cask and LDC, $100 \%$ of sludge on sludge filters is suspended) are conservative.

- It is assumed that $181 \mathrm{~kg}$ of sludge accumulates on the LDC internal filters. This value is based on the loading without backwash. With backwash, the filter loading is no greater than half that used in the analysis.

- A detonation in the LDC is assumed. Section 3.4.7 shows that a detonation would probably not occur, as the length of the LDC is not sufficient for a deflagration to transition to a detonation.

- The LDC is assumed to fail catastrophically. Appendix C shows that the likely failure mode is a split in a seam in the cylindrical shell of the LDC. The head will not come off.

The unmitigated frequency is found next.

In this case a fill gas that is an oxidizer (e.g., air) is used instead of argon. No one notices that an inert gas is not being used. The detonation case requires a large hydrogen concentration. Due to the short length of the LDC, the mole fraction must be very close to 0.3 . Detonations can occur with hydrogen mole fractions down to 0.13 to 0.15 but as was shown in Section 3.4.7.2.1 the distances needed to transition to a detonation is much greater than any LDC dimension.

The combination of the lack of an obvious spark source, long wait to flammable conditions, and ignition only at the optimal time and not at any time prior to reaching a mole fraction of 0.3 (or 0.15 ) is judged to make this event Unlikely.

As a result, the detonation case is Risk Class II onsite and Risk Class III offsite. Since the $15 \%$ hydrogen case result in an onsite dose that exceeds 100 rem, the onsite Risk Class is I and offsite Risk Class is III. 
Table 3-25. Hydrogen Burn in Sludge Transportation Cask Summary Table.

\begin{tabular}{|c|c|c|c|c|c|c|c|c|c|c|c|c|}
\hline \multirow[b]{2}{*}{ Scenario } & \multirow[b]{2}{*}{ Freq. } & \multirow{2}{*}{$\begin{array}{c}\text { MAR } \\
(\mathrm{kg})\end{array}$} & \multirow[b]{2}{*}{$\mathrm{DR}$} & \multirow[b]{2}{*}{$\mathrm{ARF}$} & \multirow[b]{2}{*}{$\mathrm{RF}$} & \multirow[b]{2}{*}{ LPF } & \multicolumn{3}{|c|}{ Collocated Worker } & \multicolumn{3}{|c|}{$\begin{array}{l}\text { Maximum Offsite } \\
\text { Individual }\end{array}$} \\
\hline & & & & & & & $\begin{array}{c}\chi / Q \\
\left(\mathrm{~s} / \mathrm{m}^{3}\right)\end{array}$ & $\begin{array}{l}\text { Dose } \\
\text { (rem) }\end{array}$ & $\begin{array}{l}\text { Risk } \\
\text { Class }\end{array}$ & $\begin{array}{c}\chi / \mathrm{Q} \\
\left(\mathrm{s} / \mathrm{m}^{3}\right)\end{array}$ & $\begin{array}{l}\text { Dose } \\
\text { (rem) }\end{array}$ & $\begin{array}{l}\text { Risk } \\
\text { Class }\end{array}$ \\
\hline $\begin{array}{l}\text { Deflagration in } \\
\text { the Cask, } \\
\text { Detonation in } \\
\text { LDC, breached } \\
\text { facility }\end{array}$ & $\mathrm{U}$ & 181 & 1.0 & $5.5 \mathrm{E}-2^{1}$ & 1 & 1 & $1.60 \mathrm{E}-3$ & 81 & II & $2.28 \mathrm{E}-5$ & 0.19 & II \\
\hline $\begin{array}{l}\text { Deflagration in } \\
\text { the Cask, } \\
\text { Detonation in } \\
\text { LDC, intact } \\
\text { facility }\end{array}$ & $\mathrm{U}$ & 181 & 1.0 & $6.6 \mathrm{E}-3^{1}$ & 1 & 1 & $8.1 \mathrm{E}-3$ & 49 & II & $1.69 \mathrm{E}-5$ & 0.17 & III \\
\hline $\begin{array}{l}\text { Deflagration in } \\
\text { the Cask, } \\
\text { Deflagration in } \\
\text { LDC }\end{array}$ & A & 181 & 1.0 & $5 \mathrm{E}-3$ & 0.3 & 1 & $7.32 \mathrm{E}-2$ & 99 & I & $4.49 \mathrm{E}-5$ & 0.10 & III \\
\hline
\end{tabular}

\subsubsection{Mitigation and Prevention Analyses}

The first mitigator is the leak path factor (LPF). The LPF only affects the Deflagration in the Cask and LDC case, as the effect of the building is already covered in the Detonation in the LDC cases. The LPF is discussed in Section 3.4.5.5 and 3.4.7.5. The LPF is calculated to be 0.5. The mitigated consequences for the Deflagration are half of the unmitigated consequences.

As discussed in Section 3.4.7.5, the LPF can reduce the deflagration dose to 50 rem onsite and 0.05 rem offsite. The AIVS system reduces the frequency by one bin. The mitigated risk is:

\begin{tabular}{|c|c|c|c|}
\hline & & Onsite & Offsite \\
\hline \multicolumn{4}{|c|}{ Detonation in LDC } \\
\hline & Breached facility & III & III \\
\hline & Intact facility & III & IV \\
\hline Deflagration & & II & III \\
\hline
\end{tabular}

Section 3.4.7.5 also provides a discussion of the other mitigating factors for which credit was not taken. 


\subsubsection{Summary of Safety Structures, Systems, Components and Technical Safety Requirement Controls}

The following safety-significant SSCs are relied upon:

- Active Inert Ventilation System. The overall safety function of the AIVS system is to maintain an inert cover gas over sludge contained in the LDC thereby reducing the likelihood of a hydrogen burn event.

- LDC inlet deflector plate as described in Section 3.4.3.5. The deflector plate protects the analysis assumption of sludge content.

- Strainer basket as described in Section 3.4.3.5. The strainer basket protects the analysis assumption of sludge content.

Safety significant TSR controls include:

- AIVS operability is ensured by an LCO. This LCO ensures the operability of the active inert ventilation system (AIVS) to ensure the oxygen concentration remains sufficiently low (below $4 \%$ ) to prevent a flammable mixture (hydrogen burn) within the LDC and the cask.

- Sludge retrieval and shipment preparation administrative controls as described in Section 3.4.3.5. This protects source term assumptions used in the analysis.

- Maintain building doors closed (see Section 3.4.7.6).

- The following additional sludge retrieval and shipment preparation controls relating to hydrogen accumulation:

- Ensuring an inert atmosphere is established and maintained in the cask annulus following placement of cask lid. This reduces the frequency of the hydrogen burn accident.

- Ensuring an inert cover gas in the LDC whenever it contains sludge. This reduces the frequency of the hydrogen burn accident.

\subsubsection{Hydrogen Burn in LDC}

This section presents the consequence of a hydrogen burn within the LDC while at K Basin.

The hazards in the Hydrogen Burn category can be grouped as follows:

1. Hydrogen and oxygen accumulate in a small gas volume above the liquid as a result of a partial decant, erroneously high sludge level, or very slow decant. 
2. Air enters the gas volume when the treated water system is operated. This only occurs if the treated water system contains air pockets as a result of a maintenance outage with failure to bleed all of the air out of the system before use.

3. Air diffuses into LDC during the time that the LDC ports are open during disconnect.

4. Air or some other gas containing an oxidizer is used instead of argon.

5. Flammable gas potentially accumulates in transfer lines if retrieval inadvertently ceases for some reason.

In addition, there exists the potential for an episodic hydrogen release if sufficient time passes for hydrogen accumulation in the sludge such that it can no longer hold the gas. The hydrogen generation rate could change due to a layer collapse, wrong sludge composition or excessively long staging time.

Appendix B provides scoping calculations of the final pressure should hydrogen and oxygen burn within the LDC. Appendix B shows that if hydrogen is produced chemically and by radiolysis and oxygen is produced only by radiolysis, the worst case pressures occur for those cases where the LDC headspace (the volume above the liquid) is air filled. The peak pressures are shown for two different hydrogen mole fractions.

$\begin{array}{ccc}\begin{array}{c}\text { Hydrogen Mole } \\ \text { Fraction }\end{array} & \text { Peak Pressure, psig } & \begin{array}{c}\text { Case Number in } \\ \text { Appendix B }\end{array} \\ 0.3 & 288 & 1,2 \mathrm{a}, 5,6 \\ 0.15 & 151 & 3,4\end{array}$

\section{Flammability Considerations}

A flammable condition exists when the oxygen content reaches $5 \%$ for hydrogen, oxygen and nitrogen systems (Figure 8, page 21 of Bulletin 503, Limits of Flammability of Gases and Vapors). The lower flammability limit is $4 \%$ hydrogen.

Another approach to obtain the minimum oxygen portion is as follows. Figure 7 of the Bulletin provides a graph of the flammability limits of air, hydrogen, and nitrogen. It is seen from the figure that if the fraction of oxygen in the mix is less than $4.9 \%$, the mixture is not flammable. At this minimum point, the hydrogen fraction is $4 \%$ to $5 \%$. The Bulletin goes on to state (see Figure 8) that in mixtures of air, hydrogen, and nitrogen, if there is less than $4.9 \%$ oxygen, the mixture is not flammable regardless of the hydrogen fraction. For example, a mix of $20 \%$ hydrogen, $6 \%$ oxygen, and $74 \%$ nitrogen is flammable. However, a mix of $20 \%$ hydrogen, $4 \%$ oxygen, and $76 \%$ nitrogen is not.

A similar curve for mixtures of hydrogen, air, and argon is not provided in the Bulletin; however, the lower flammability limit (LFL) and upper flammability unit (UFL) for hydrogen in an oxygen-argon mixture are given. Page 23 of Bulletin 503 also states that in a specific atmosphere of oxygen-argon $\left(21 \% \mathrm{O}_{2}\right.$ and $79 \%$ of Ar) and hydrogen, the LFL is $3.2 \%$ (per the 
reference, this case is "hydrogen in air with argon substituted for the nitrogen"). The UFL is $76.4 \%$. Since the UFL represents the condition of minimal oxygen, the UFL can be used as a best estimate of the minimum oxygen fraction. In a $76.4 \%$ hydrogen mixture, oxygen-argon makes up $23.6 \%$. Since the oxygen-argon mixture contains $21 \%$ oxygen, an estimate of the minimum oxygen percentage needed for combustion is $21 \%$ of $23.6 \%(0.21 \times 0.236)$, or $5 \%$.

The minimum oxygen fraction can also be obtained by assuming that the minimum oxygen fraction was proportional to the ratio of the LFL of hydrogen in air to the LFL of hydrogen in the oxygen-argon mix. This yields a value of $4 \%(5 \% \times 3.2 \% / 4 \%)$. Since the hydrogen fraction at the minimum oxygen fraction is $4 \%-5 \%$, this would be a reasonable estimate of the minimum oxygen fraction. Note that since the minimum hydrogen fraction at the minimum oxygen fraction is a little greater than the LFL, the ratio may underpredict the minimum oxygen fraction.

Failures in flushing the treated water system or extended times when the LDC ports are open following disconnect could result in air ingress to the point that sufficient oxygen could be present in the LDC to result in a flammable condition after a period of time needed for hydrogen generation.

\section{Gas Generation Rate}

SNF-18133 provides a discussion of hydrogen and oxygen generation rates and behavior.

The Modified Safety Basis case of SNF-18133 is used in this analysis. The modified Safety Basis Case is similar to the Safety Basis case used in Section 3.4.3 above with the following exceptions. First, the decay heat has been reduced from $139 \mathrm{~W}\left(69.9 \mathrm{~W} / \mathrm{m}^{3}\right.$ in the $2 \mathrm{~m}^{3}$ payload within the LDC) to $88 \mathrm{~W}\left(44 \mathrm{~W} / \mathrm{m}^{3}\right)$ based on sample data as explained in SNF-18133. Second, the hydrogen and oxygen generation rate due to radiolysis is lower based on the lower decay heat and a more accurate determination of the fraction of the radiation being emitted by the particle getting into the liquid. The sludge temperature used in the Modified Safety Basis case is closer to that of the sludge in the basin. Third, credit is taken for oxygen reactions with uranium metal delaying hydrogen production by chemical reaction and for oxygen reaction with $\mathrm{UO}_{2}$, minimizing the oxygen that is released into the headspace.

The sludge matrix contains dissolved oxygen present in the basin water as the sludge is pumped to the LDC and contains dissolved and non-dissolved oxygen (or oxidizing species) produced from the radiolysis of water after the sludge is loaded into the LDC. Oxygen from both of these sources reacts with the uranium metal and uranium oxides present in the sludge. This oxygen dramatically affects the onset of the evolution of hydrogen from the uranium-water reaction, the reaction responsible for the majority of the hydrogen postulated to be generated in the LDC shortly after loading. The effect of this oxygen is to essentially "poison" the uranium-water reaction, preventing the evolution of hydrogen from this reaction until the oxygen in the sludge has been depleted. The primary effect of these oxygen sources is to delay, by a substantial time, the onset of hydrogen evolution from the uranium-water reaction. The reaction of oxygen with uranium metal and uranium dioxide also delays for a very long time (months to years) oxygen evolution from the sludge into the headspace. 
A more reasonable case, called the "Reasonably Bounding Case" is also provided within SNF-18133. This case removes some of the conservatisms from the Modified Safety Basis Case. A comparison of the Modified Safety Basis Case and the Reasonably Bounding Case is shown below. To be conservative, the Modified Safety Basis Case is used in the analysis.

Table 3-26. Hydrogen Burn Parameters

\begin{tabular}{|c|c|c|}
\hline Parameter & $\begin{array}{l}\text { Modified Safety Basis Case from } \\
\text { SNF-18133 }\end{array}$ & $\begin{array}{l}\text { Reasonably Bounding Case from } \\
\text { SNF-18133 }\end{array}$ \\
\hline Decay Heat, $\mathrm{W} / \mathrm{m}^{3}$ & 44 & 36.2 \\
\hline \multicolumn{3}{|l|}{ Enhancement Factor for } \\
\hline Hydrogen generation & 3 & 1 \\
\hline Oxygen Reactions & 1 & 1 \\
\hline $\begin{array}{l}\text { Uranium Metal Concentration in } \\
60: 40 \mathrm{Mix}, \mathrm{kg} / \mathrm{m}^{3}\end{array}$ & 63.8 & 55.5 \\
\hline $\begin{array}{l}\text { Total Uranium Concentration in } \\
60: 40 \mathrm{Mix}, \mathrm{kg} / \mathrm{m}^{3}\end{array}$ & 740 & 632 \\
\hline Uranium Metal Particle Size, $\mu \mathrm{m}$ & 500 & 750 \\
\hline Hydrogen generation rate ${ }^{t}$ & $\begin{array}{c}\text { From SNF-18133, Attachment } \\
\text { 14D, page } 3\end{array}$ & $\begin{array}{c}\text { From SNF-18133, Attachment } \\
\text { 15D, page } 3\end{array}$ \\
\hline Radiolysis, L/day & 4 & 3.4 \\
\hline Chemical, $\mathrm{L} / \mathrm{hr}$ & 12 & 2.3 \\
\hline \multicolumn{3}{|l|}{$\begin{array}{l}\text { Time to } 48 \mathrm{~L} \text { of hydrogen in } \\
\text { LDC }^{2} \text { (Only a concern if the LDC } \\
\text { has an air atmosphere) }\end{array}$} \\
\hline Episodic Release Case ${ }^{3}$ & $\begin{array}{l}12.13 \text { days (SNF-18133, } \\
\text { Attachment 14D) }\end{array}$ & $\begin{array}{l}12.88 \text { days (SNF-18133, } \\
\text { Attachment } 15 \mathrm{D})\end{array}$ \\
\hline Continuous Release Case $^{4}$ & $\begin{array}{c}3.94 \text { hrs (after oxygen poisoning } \\
\text { ceases) }\end{array}$ & $\begin{array}{c}19.5 \mathrm{hrs} \text { (after oxygen poisoning } \\
\text { ceases) }\end{array}$ \\
\hline $\begin{array}{l}\text { Volume of oxygen released into } \\
\text { the LDC headspace }\end{array}$ & $\begin{array}{c}\text { None (per Table ES-1 of SNF- } \\
18133 \text { ) }\end{array}$ & $\begin{array}{c}\text { None (per Table ES-1 of } \\
\text { SNF-18133) }\end{array}$ \\
\hline \multicolumn{3}{|c|}{$\begin{array}{l}\text { Note 1: Based on atmospheric pressure and } 298 \mathrm{~K} \text {. The chemical generation rate varies with temperature } \\
\text { Note 2: } 48 \mathrm{~L} \text { is } 4 \% \text { of the minimum headspace volume within an LDC of } 1200 \mathrm{~L} \text {. } \\
\text { Note 3: Time to } 48 \mathrm{~L} \text { is found assuming that } 0.2 \mathrm{~m}^{3} \text { of sludge is loaded into the LDC every } 12 \text { hrs. Initial } \\
\text { temperature is } 15{ }^{\circ} \mathrm{C} \text {. Sludge temperature increases due to decay heat. Gas accumulates in the sludge until } \\
48 \mathrm{~L} \text { has been generated and is then assumed to be released into the LDC headspace. } \\
\text { Note 4: Assumes that the LDC is filled as in Note } 3 \text {, but no gas accumulates in the sludge. Time is the } \\
\text { time to } 48 \mathrm{~L} \text { assuming gas generation in the entire } 2 \mathrm{~m}^{3} \text { payload. }\end{array}$} \\
\hline
\end{tabular}

Attachment 8 of SNF-18133 provides a detailed discussion of generation of hydrogen and oxygen due to radiolysis for the Modified Safety Basis Case.

First the fraction of the delay heat that comes from alpha, beta and gamma energy is determined. Next the fraction of that energy deposited in the water (and that deposited in the particles) is determined. This is then multiplied by the values for $\mathrm{G}\left(\mathrm{H}_{2}\right)$ and $\mathrm{G}\left(\mathrm{O}_{2}\right)$.

SNF-18133, Attachments 4 and 5 show that oxygen reacts with uranium metal and with uranium dioxide. The reaction rates are experimentally derived rates and are a function of oxygen solubility, the temperature of the sludge, the particle size, and uranium mass. The Modified Safety basis parameters from SNF-18133 were used in this analysis. SNF-18133 shows that hydrogen is not produced by chemical reaction until all of the oxygen dissolved in the water has reacted with either uranium metal or uranium dioxide. This is called oxygen poisoning. The 
reaction of oxygen with uranium species is called oxygen depletion. The report also shows that oxygen would not be seen in the LDC headspace until all of the uranium has reacted. Hydrogen is generated by radiolysis at all times and will get to the LDC headspace and cask.

Using the generation rates due to radiolysis and the reaction rates for oxygen depletion and oxygen poisoning, and a slow temperature increase due to decay heat, it is found that flammable conditions are never reached in the LDC headspace (space above liquid level) or cask over any period of time, as long as the headspace and cask are filled with argon. Hydrogen could build up in the sludge creating gas pockets. After a long period of time and under the right conditions, oxygen could start to build up in the sludge as well. The retained gases could be quickly released into the headspace due to shock or vibration. The time span for hydrogen to get into the headspace could be the same or longer than that above. The time at which the atmosphere could possibly become flammable is very much longer as oxygen gas is not created until most or all of the uranium has reacted.

\section{Determination of the Worst Case Accident}

The worst-case accident comes from group 4, "Air or some other oxidizing gas is used instead of argon." In this case there is ample oxygen to react with the hydrogen. Group 1, the partial decant cases, will achieve flammable conditions sooner but the peak pressure is very small due to the lack of oxygen if it is assumed that the LDC gas space fills with argon during the purge. If argon is assumed not to be present, then the peak pressures are similar to those for Group 4 under conditions of equal hydrogen to oxygen mole fractions.

The group 3 case contains only a small amount of oxygen, as the quantity of air entering the system is small. It is Extremely Unlikely for the group 2 case to create a flammable condition in an argon-filled atmosphere. The treated water system piping (Group 2) is 3 to 4 inches in diameter. Assume 4 inches in diameter for this calculation. It was shown above that in an argon environment, the oxygen concentration must be at least $5 \%$ for a flammable condition to occur. In a minimum LDC headspace of $1200 \mathrm{~L}, 5 \%$ corresponds to $60 \mathrm{~L}$. To obtain $60 \mathrm{~L}$ of oxygen, $286 \mathrm{~L}$ of air must enter the LDC ( $60 \mathrm{~L}$ is $21 \%$ of $286 \mathrm{~L})$. This equates to $116 \mathrm{ft}$ of air filled 4-inch line. It is, therefore, Extremely Unlikely that $116 \mathrm{ft}$ of piping will be totally air filled following maintenance. Lastly, in Group 3, the gas pocket is vented. If the gas did ignite the pressure pulse would be less.

Group 5 is much like Group 1 and likely contains less hydrogen and oxygen due to the use of small diameter lines. The consequences of this event would be very small as the amount of sludge affected by such a burn is very much less than the quantity assumed in the worst-case accident. In addition, there is very likely no spark source in the vicinity of the gas pocket as the lines do not contain spark sources with the exception of a few moving valves. If there were a detonation, the lines are likely able to withstand the effects. Calculation T-CLC-H-00662, Evaluation of the High Level Waste Transfer Piping System for Potential Explosion Loads, provides the stresses and strains in the piping system due to a hydrogen-air detonation. The piping analyzed was 4 in. diameter, Schedule 10S, type $304 \mathrm{~L}$ stainless steel. A detonation was postulated in the piping. The peak pressure due to the detonation was $543 \mathrm{psig}$. Thermal effects were also considered. A detailed finite-element analysis of the piping system showed that the peak pressure does not exceed the allowable pressure for $5 \%$ strain. Therefore the piping did not 


\section{SNF-10272 REV. 2}

fail. Since there is no air in the fill lines, there would be little oxygen unless the chemical generation of hydrogen was delayed. This event is therefore an Unlikely to Extremely Unlikely Worker Safety event due to small quantity of sludge affected, lack of ignition source and the potential of little oxygen with the hydrogen being generated and potential for the piping to survive even if an ignition occurred.

The Group 2 and 3 accidents yield some oxygen in the headspace more quickly than is the case for Group 1. The time needed to obtain a flammable concentration for Group 3 events is about 5 days (calculations in SNF-18135, Design Calculations for Gas Flow and Diffusion in Large Diameter Container and Cask, show 1.1\% air mixture due to diffusion over $28 \mathrm{hrs)}$

\subsubsection{Scenario Development}

In this case the operators use an oxidizing gas in the process rather than argon. This would require a failure in the $\mathrm{QA} / \mathrm{QC}$ process to check that the correct gas has been purchased and a failure to detect oxygen with the oxygen monitor. Note that if the oxidizing gas contains no oxygen (such as fluorine), the oxygen monitoring would be of no use. Gases like fluorine that can react with hydrogen should be prohibited from use.

It is assumed, in this case, that the minimum LDC volume is $1.2 \mathrm{~m}^{3}$. The LDC pressure is $1.68 \mathrm{~atm}$ (abs), $5 \mathrm{psi}$ above the normal operating pressure of the gas system. The initial temperature is $298 \mathrm{~K}$. The hydrogen generation rate is such that at some point, a flammable condition is attained and at some later point, a hydrogen mole fraction of 0.3 is attained. The analysis will be performed assuming that the hydrogen mole fraction in the final mix of gas is 0.3 as this results in the largest energy release when ignited in air.

If the environment were argon, not air, hydrogen would never build to a flammable concentration as discussed above.

\section{Spark Source Discussion}

The ignition source is not readily apparent. The only equipment hanging in the LDC is the level probe. The level probe extends about 8 to 9 inches into the LDC. It is made of metal and has a stainless steel connecting rod that connects the probe to the exterior of the tank via one of the nozzles. The level probe is about 8 inches above the stainless grating that constitutes the upper support of the sludge filters. The filters are steel wire wrapped polypropylene or similar material that are likely covered with a wet sludge. In addition, the XCT-12 transducer on the level probe is approved by Factory Mutual Global (FM) for operation in National Electrical Code (NEC) Class I, Division 2, Groups A, B, C, and D and NEC Class II, Division 2, Groups F \& G locations. The classes and groups are described in Article 500 of the NEC. During that period of time when the transducer will be operating, the void space of the LDC will fit most nearly the definition for a Class I, Division 2 location (NEC Art 500.5B):

A Class I, Division 2 location is a location in which ignitable concentrations of gases or vapors are normally prevented by positive mechanical ventilation, and which might become hazardous through failure or abnormal operation of the ventilating equipment. 
The Product Manager for the transducer stated that there are probably only two scenarios under which the transducer could generate a spark:

- The transducer had corroded to a point where both the enclosure and the encapsulant were removed, and a gap was created between the electrodes (not normally there.) This highly unlikely event would only occur if the corrosion resistant coating of the transducer were damaged on installation and exposed to a highly corrosive environment during its lifecycle, and only then after a period of several years.

- The transducer was damaged severely at some point during operation. Again, this damage would have to be such that both enclosure and encapsulant were removed, and a gap created between the transducer electrodes. This too is a highly unlikely event.

Failures in the level probe should not cause a short to the steel grating because of the distance from the probe to the grating.

A potential spark source is static build up on the argon nozzle during and after gas flow. Again, the point to which it might discharge is far away. A spark source will nevertheless be assumed to be present, albeit very unlikely.

\subsubsection{Source Term Analysis}

Appendix B, Case 1, shows that for an LDC filled to $1600 \mathrm{~L}$ with air and hydrogen accumulation such that the final gas mix has $30 \%$ hydrogen, the peak pressure is 288 psig assuming an initial pressure before hydrogen build up of $1.68 \mathrm{~atm}$ (abs) (10 psig) and an initial temperature of 298 $\mathrm{K}$. A similar value is obtained from a no argon, $1200 \mathrm{~L} \mathrm{LDC}$ open volume case (Case 2a) also shown in the spreadsheet listings in Appendix B.

AVANTech Calculation Number ER-3C-0126-07, K-East Basin Sludge Transport System Large Diameter Container; Factory Acceptance Test Report, shows that the LDC passed a hydrostatic pressure test of $225 \mathrm{psig}$. The peak pressure of $288 \mathrm{psig}$ is only slightly above the hydrostatic pressure used in the test. However, since the case being analyzed contains $30 \%$ hydrogen with sufficient oxygen in the air of the LDC atmosphere to react nearly all of it, the effects of a detonation must be considered.

There is no means to ignite the mixture such that a detonation occurs immediately (called "direct initiation"). Energy sources equivalent to $1 \mathrm{~g}$ of high explosive or intense hot jet that is about $0.2 \mathrm{~m}$ in diameter are needed for direct initiation of the detonation (Section 3.4 of Moen [1993]).

However, ignition could result in a transition to a detonation. Section 5.2 of the same reference stated that in stoichiometric hydrogen - air mixture (which is the mixture in this analysis), transition to a detonation could occur in a $3 \mathrm{~m}$ long tube with obstacles. Experiments done on a $3 \mathrm{~m}$ by $3 \mathrm{~m}$ enclosure with no obstacles, but with a fan creating turbulence, showed transition to detonation $2 \mathrm{~m}$ downstream of the fan. The distance from the sludge level (without cover water addition) to the top of the LDC is about $1.5 \mathrm{~m}$ as is the side-to-side distance. Therefore, it would appear that a detonation could not occur within the LDC as the length for run-up (to a detonation) is too short. 


\section{SNF-10272 REV. 2}

However, Zalash (1993) Hydrogen Combustion in Reactor Containment Building, Vol. 2 A Review of the Experimental Data and State-of-the-Art Computer Codes, reviewed some run-up data for near-stoichiometric hydrogen-air mixture and concluded that there was neither a constant induction length (i.e., run-up distance) nor constant $\mathrm{L} / \mathrm{D}$ ratio for hydrogen-air transition to detonation in different size pipes and that the pressure of turbulence-generating obstacles generally large scales, and complex geometries available in industrial situations negate the predictive value of laboratory measured run-up distances.

Because of the lack of direct experimental data that can be used to argue persuasively for or against a detonation in the LDC and because there are experimental results that show detonation in enclosures only $33 \%$ longer ( $2 \mathrm{~m}$ vs. $1.5 \mathrm{~m}$ in LDC), another method was investigated.

The presence of the 55 sludge filters and other internal structure will break up the flame front causing a much faster reaction. These phenomena could result in the transition of the deflagration to a detonation. A simple method to determine the likelihood of a detonation is given in FAI/96-29, Detonation Potential for Selected Hanford Tank Farm Applications. The method is taken from a Nuclear Regulatory Commission sponsored report (NUREG/CR-4803, The Possibility of Local Detonation During Degraded-Core Accidents at the Bellefonte Nuclear Power Plant) that considered the potential of a hydrogen detonation in commercial nuclear reactor accidents. The method is, however general in nature and is based on hydrogen burns in pipes and vessels. Therefore, it can be used in this case as well.

In the method, the likelihood is a function of the mixture class and the geometry class. They are given by the following:

$\begin{array}{cc}\text { Mixture Class } & \frac{\text { Approximate Hydrogen Mole }}{\text { Fraction }(0 \text { to } 0.3)} \\ 1 & 0.2 \text { to } 0.3 \\ 2 & 0.19 \text { to } 0.22 \\ 3 & 0.13 \text { to } 0.19 \\ 4 & 0.11 \text { to } 0.13 \\ 5 & <0.11\end{array}$


Geometry Class

$\underline{1}$

$\underline{2}$

$\underline{3}$

$\underline{4}$

$\underline{5}$

\section{Description}

Large volume with obstacles in the path of the expanding unburned gas. Example is a large tube with numerous obstacles and with ignition going from a closed end to an open end.

Similar to Class 1, but with features that hinder flame acceleration. Example is a tube open on both ends of a large amount of transverse volume for flame expansion.

Geometries that yield moderate flame acceleration. Examples are large tubes without obstacles or small tubes (several inches in diameter) with obstacles.

Geometries unfavorable to flame acceleration. Examples are large volumes with few obstacles and large amount of transverse volume for expansion or small volumes without obstacles.

Very unfavorable to flame acceleration, like large open volumes or a small spherical geometry with out obstacles and central ignition.

The relationship to likelihood of detonation, mixture class and geometry class is as follows:

\begin{tabular}{|c|c|c|c|c|c|}
\hline Table entry is "Result class" (See below) & \multicolumn{5}{|c|}{ Mixture Class } \\
\hline Geometry Class & $\mathbf{1}$ & $\mathbf{2}$ & $\mathbf{3}$ & $\mathbf{4}$ & $\mathbf{5}$ \\
\hline $\mathbf{1}$ & 1 & 1 & 2 & 3 & 4 \\
\hline $\mathbf{2}$ & 1 & 2 & 3 & 4 & 6 \\
\hline $\mathbf{3}$ & 2 & 3 & 3 & 4 & 5 \\
\hline $\mathbf{4}$ & 3 & 4 & 4 & 5 & 5 \\
\hline $\mathbf{5}$ & 4 & 5 & 5 & 5 & 5 \\
\hline Results Class: & \\
1. Deflagration to Detonation Transition (DDT) is highly likely \\
$\begin{array}{l}\text { 2. DDT is likely } \\
\text { 3. DDT may occur } \\
\text { 4. DDT is very unlikely } \\
\text { 5. DDT is impossible }\end{array}$
\end{tabular}

A mixture of $30 \%$ hydrogen in air is Mixture Class 1 . The LDC is Geometry Class 1 or maybe 2. In either case, the transition to a detonation is likely to highly likely. 
Because experiments show that transition to a detonation can occur in as short a distance as $2 \mathrm{~m}$ in enclosures of similar size as the LDC and because the methodology taken from NUREG/CR4803 shows that a detonation is "highly likely", a detonation is postulated.

A detonation starting at $2.6 \mathrm{~atm}$ (absolute), the final pressure after hydrogen has accumulated to the point that the mole fraction of hydrogen is 0.3 , yields a shock wave. The shock wave pressure is found by extrapolation from FM 99-5, Validation of Detailed Reaction Mechanisms for Detonation Simulation, and found to be $41.6 \mathrm{~atm}$ or 609 psia.

The LDC is rated at 150 psig. Appendix $\mathrm{C}$ shows that the burst pressure is approximately $850 \mathrm{psi}$. To determine the effect on the LDC due to the detonation, the pressure must be multiplied by a dynamic load factor. The dynamic load factor is used to determine quasi-steady state pressure during dynamic conditions, such as a rapid hydrogen burn. A conservative value for the dynamic load factor of 2.0 is used in this case to cover the uncertainties. Multiplying the LDC pressure by a factor of 2 yields a pressure of 1218 psia. This pressure exceeds the burst pressure of $850 \mathrm{psi}$, as discussed above. Therefore, the LDC fails catastrophically. This will also result in the cask lid coming off. Appendix B shows that with $15 \%$ hydrogen the peak pressure is $151 \mathrm{psig}$. A detonation will not occur in this mixture as the distances needed to transition to detonation exceed the length or width of the LDC. As an example, NUREG/CR5275, FLAME Facility, provides the results of hydrogen burns and transition to detonation in a rectangular pipe $1.8 \mathrm{~m}$ wide by $2.4 \mathrm{~m}$ tall and $30 \mathrm{~m}$ long. Page 73 of the reference shows that with obstacles occupying $33 \%$ of the area and no venting (venting leads to lower flame speeds), a transition to detonation occurs $15 \mathrm{~m}$ from the end.

The analysis shows that

- $30 \%$ hydrogen - a detonation occurs with LDC and cask failure

- $15 \%$ hydrogen - a deflagration occurs with no vessel failure.

\section{Quantity of Aerosol Released - Detonation}

Page 4-8 of DOE-HDBK-3010-94 provides the respirable release fraction for a case involving a detonation in a confined area where immediate dissipation of the blast effects is not anticipated. The airborne release fraction (ARF) is given by the reference as 1.0. The respirable fraction $(R F)$ is stated to be the initial respirable fraction of the material. The RF of the material on the sludge filters is not known. It is assumed to be high and will be chosen to be 1.0 for this analysis. As a result, the entire filter inventory of $181 \mathrm{~kg}$ (see Section 3.4.5.2) is lofted into the air by the blast forces following the failure of the LDC and cask by the shock wave.

In addition to the aerosol release from the sludge filters, there may be a release from the sludge beneath the water layer in the lower portion of the LDC. The situation is a gas explosion (shock wave followed by blast wave) impacting the surface of the water and sludge mixture. The worst case for the release of this liquid, per DOE-HDBK-3010-94, is if there is gas entrained within the liquid. The reaction of uranium and water creates hydrogen that can be captured within the sludge. Therefore, when the sludge is pressurized and then rapidly depressurized, the expanding entrained gas could carry some of the liquid and sludge out. DOE-HDBK-3010-94, Table 3-3 
provides the ARF*RF for cases in which UNH (density of $1.3 \mathrm{~g} / \mathrm{cm}^{3}$, compared to sludge density of $1.9 \mathrm{~g} / \mathrm{cm}^{3}$ ) is released after being pressurized to $500 \mathrm{psi}$ and then depressurized. The worstcase ARF*RF is 7E-04 for the largest source volume $(350 \mathrm{ml})$. The amount of sludge in the lower portion of the LDC is $3800 \mathrm{~kg}$ (from $2 \mathrm{~m}^{3}$ of sludge having a density of $1.9 \mathrm{~g} / \mathrm{cm}^{3}$ ). Multiplying $7 \mathrm{E}-04$ by $3800 \mathrm{~kg}$ yields $2.7 \mathrm{~kg}$. This release is small as compared to the $181 \mathrm{~kg}$ of aerosol from the sludge filters.

The release from the sludge in the lower portion of the LDC will be neglected because the release of $2.7 \mathrm{~kg}$ is very conservative. First, the amount of gas in the sludge can be any fraction from 0.0 to 0.35 (the peak gas fraction able to be retained in the sludge). Compression followed by decompression will not affect all of the sludge in this case. The gas may move out of the sludge without disturbing much sludge if it moves through channels. It is recognized that $\mathrm{UNH}$ solutions are not exactly like sludge in water covered by a layer of water with no sludge. However, since the sludge is formed of uranium and other comparatively heavy particles and, since the sludge has a yield strength where as $\mathrm{UNH}$ does not, the release of the uranium particulates from the sludge should be less than the release of uranium from UNH. Also, the data in DOE-HDBK-3010-94 indicates that the release fraction decreases with increasing liquid (source) volume.

Assume that initially no building is present. Initially, the gases and aerosol blown out by the explosion will expand to atmospheric pressure. The volume after expansion will be determined next.

The initial conditions within the LDC after the hydrogen burn (Case $2 b$ of Appendix B - see spreadsheet at end of the Appendix with no oxygen being generated) are:

$$
\begin{aligned}
& \text { Temperature }\left(T_{i}\right)=2971 \mathrm{~K} \\
& \text { Pressure }\left(P_{i}\right)=20.4 \mathrm{~atm}, \text { absolute } \\
& \text { Volume }\left(V_{i}\right)=1.2 \mathrm{~m}^{3} \\
& \text { Number of moles }(n)=100.5 .
\end{aligned}
$$

The conditions after the expansion are found as follows:

$$
\frac{T_{f}}{T_{i}}=\frac{P_{f}^{\frac{k-1}{k}}}{P_{i}^{\frac{k-1}{k}}}
$$

where $\mathrm{k}=$ ratio of the specific heats $=1.4$

Given $P_{i}$, and $T_{i}$ above, and assuming that after expansion, $P_{f}$ is $1 \mathrm{~atm}, T_{f}$ is found to be $1255 \mathrm{~K}$. The volume is found from the ideal gas law. Solving for $V_{f}$ yields $10.3 \mathrm{~m}^{3}$. The volume is a sphere $2.7 \mathrm{~m}$ in diameter. 


\section{SNF-10272 REV. 2}

The gas and small aerosol particulates will for a cylindrical plume continue to rise, expand, entrain air and cool. Given the geometry of the situation (LDC is a cask with the lid off or blown off, and LDC bursts), the plume will spread much more axially than radially. The plume height is found next.

AEC (1968), Meteorology and Atomic Energy, Section 5-2.2, shows the plume rise from explosions. The equation for plume height is:

$$
\mathrm{h}=2.66 *\left(\frac{Q}{c_{p} \rho[\partial \Theta / \partial z]}\right)^{0.25}
$$

where $Q=$ energy of the explosion, cal

$$
=2.03 \times 10^{6} \mathrm{cal} \text { (Case } 2 \mathrm{~b} \text { in Appendix B) }
$$

$\mathrm{c}_{\mathrm{p}}=$ specific heat of air

$=0.24 \mathrm{cal} / \mathrm{g}-\mathrm{C}$

$\rho=0.00118 \mathrm{~g} / \mathrm{cm}^{3}$ at $25 \mathrm{C}$

$\partial \Theta / \partial z=0.000065 \mathrm{C} / \mathrm{cm}$ (per the reference, Section 2-5)

Solving for "h" yields $8620 \mathrm{~cm}$ or $86 \mathrm{~m}$.

As the plume rises, it will expand laterally. The height increases to $86 \mathrm{~m}$. Assume that the plume diameter increases to $10 \mathrm{~m}$. The plume volume is $6754 \mathrm{~m}^{3}$. The aerosol density in the plume is:

$$
\text { Plume aerosol density }=181,000 \mathrm{~g} / 6754 \mathrm{~m}^{3}=26.8 \mathrm{~g} / \mathrm{m}^{3} \text { (wet sludge). }
$$

The sludge will dry out. The following information is taken from HNF-SD-SNF-TI-015 Volume 2. The density of wet sludge is $1.9 \mathrm{~g} / \mathrm{cm}^{3}$. The initial water fraction by volume is 0.75 . If the water is removed from the sludge and the void is not filled in, the dry sludge density is $1.15 \mathrm{~g} / \mathrm{cm}^{3}$ (from $1.9-0.75$ ). The ratio of dry density to the wet density is 1.15 to 1.9 or 0.6 . Using this value, the dry plume aerosol density is $16 \mathrm{~g} / \mathrm{m}^{3}$.

This is a very large aerosol fraction to maintain after the blast effects have dissipated. While the blast effects are present, the concentration (and even larger concentrations) can be maintained. After the blast has dissipated, the aerosol density will decrease due to agglomeration, sedimentation, and interception of the small particles by the large particles as they fall. After the blast effects have dissipated, generally quiescent air at a low flow rate is all that is left to suspend the aerosol. Previous studies have shown that while high wind speeds can maintain a greater concentration, the associated decrease in $\chi / \mathrm{Q}$ will result in lower downwind doses.

Examples of largest steady-state aerosol concentrations are as follows (data from NUREG/CR2651, Accident Generated Particulate Materials and their Characteristics $-A$ Review of the Background Information: (see also Section 3.4.10.2)

$$
\mathrm{Smog} \text { - to } 50 \mathrm{mg} / \mathrm{m}^{3}
$$

Industrial atmosphere - to $50 \mathrm{mg} / \mathrm{m}^{3}$ 


$$
\text { Mine air - to } 500 \mathrm{mg} / \mathrm{m}^{3}
$$

In addition, NUREG/CR-2651, Section 2.4.14 states that after an explosion, the maximum quasisteady state aerosol concentration is $100 \mathrm{mg} / \mathrm{m}^{3}$ a few minutes after the explosion has ended. This value is also shown in ANSI N46.1-1980, Guidance for Defining Safety-Related Features of Nuclear Fuel Cycle Facilities. For conservatism, a value of $500 \mathrm{mg} / \mathrm{m}^{3}$ will be used in the analysis because of turbulent mixing in the surrounding air that can maintain a greater aerosol loading.

Since the aerosol removal will be relatively fast, the removal will be modeled by a fall-out factor. The fall-out factor is:

$$
\text { Fall-out factor }=\left(0.5 \mathrm{~g} / \mathrm{m}^{3}\right) /(16) \mathrm{g} / \mathrm{m}^{3}=0.031 \text {. }
$$

The aerosol quantity available for downwind transport is therefore:

$$
181 \mathrm{~kg} \times 0.031=5.6 \mathrm{~kg} \text {. }
$$

Another way to determine the down-wind release is to multiply the aerosol concentration of $0.5 \mathrm{~g} / \mathrm{m}^{3}$ by the plume volume of $6754 \mathrm{~m}^{3}$ and by $1 / 0.6$, the ratio of wet to dry sludge densities, to obtain $5.6 \mathrm{~kg}$.

If the LDC and cask failure is considered to produce immediate dissipation of the blast effects, the use of an ARF of 1.0 with RF equal to the initial RF of the particles (used above) is not appropriate. Since the LDC and cask fail catastrophically, the aerosol release from vented pressurized containers is the phenomenon in DOE-HDBK-3010-94 most like the phenomenon that is postulated to occur. The ARF*RF for this phenomenon is taken from Table 4-12 of DOE-HDBK-3010-94. The values of ARF*RF at $500 \mathrm{psi}$ and $250 \mathrm{psi}$ for both $\mathrm{UO}_{2}$ and $\mathrm{TiO}_{2}$ are similar and range from 0.02 to 0.05 . Using these values with $181 \mathrm{~kg}$ of dry sludge results in a respirable release of 3.6 to $9 \mathrm{~kg}$.

Lastly, HNF-12563, Section 6.6, shows a release of 9.1 to $9.6 \mathrm{~kg}$ into the LDC from the sludge filters as a result of the detonation based on the calculations performed by the code used. Based on the above, for this analysis, a respirable release of $10 \mathrm{~kg}$ will be assumed as a bounding value. All of the $10 \mathrm{~kg}$ is assumed to be respirable for the same reasons as above.

Two cases for the detonation in a pressurized LDC are considered. In the first case, the release is assumed to be inside of the structure surrounding the basin. The structure is $190 \mathrm{ft}$ long, $90 \mathrm{ft}$ wide and $25 \mathrm{ft}$ tall. It is assumed, in this case, that the detonation does not fail the structure. If the structure fails, the release will be like that of a buoyant plume to be addressed next. The aerosol and gases generated due to the detonation flow into the structure. There they are gradually transported out over time. Because the time spent in the facility is at least on the order of minutes, a concentration of $100 \mathrm{mg} / \mathrm{m}^{3}$ can be used in determining the release. The value of $100 \mathrm{mg} / \mathrm{m}^{3}$ was discussed above. The building volume is $1.2 \times 10^{4} \mathrm{~m}^{3}$. The respirable release is, therefore: 


$$
\frac{100 \mathrm{mg}}{m^{3}} *\left(\frac{g}{1000 \mathrm{mg}}\right) *\left(1.2 \times 10^{4} \mathrm{~m}^{3}\right)=1200 \mathrm{~g} \text { or } 1.2 \mathrm{~kg} \text {. }
$$

In the second case, the detonation is assumed to open a hole in the roof of the structure. The plume is assumed to rise through the hole and then spread laterally. This release mechanism was modeled above ( $86 \mathrm{~m}$ tall plume, $10 \mathrm{~m}$ wide). The respirable release is $10 \mathrm{~kg}$ as discussed above.

\section{Quantity of Aerosol Released - Deflagration}

The $15 \%$ hydrogen case results in a deflagration with LDC survival. It is assumed, however, that the port caps or piping connections fail such that there is a flow path out of the LDC. The release is modeled as follows:

There are numerous ways to estimate the release from an explosive event. Source term estimation based on the TNT equivalence approach (see Steindler and Seefeldt [1980], A Method for Estimating the Challenge to an Air Cleaning System Resulting from an Accidental Explosive Event and NUREG/CR-4593, Initial Concepts on Energetic and Mass Releases During Nonnuclear Explosive Events in Fuel Cycle Facilities) is one approach. The disadvantage of this method is that it requires significant extrapolation beyond the test results for applications to high mass ratios of inert material to TNT equivalent mass. There is also uncertainty associated with the differences between test results based on inert material placed around the explosive as applied to an explosive gas surrounding inert material as well as uncertainty associated with the differences between test results based on inert material that is solid and their application to inert material that is already in particulate form. Since the quantities involved extrapolations to great distances away from the data provided, this method will not be used here.

The key phenomenological effect of hydrogen ignition in a container is material suspension due to the shock and blast wave and the subsequent overpressurization and rapid venting of the container. The heat is relatively small, equivalent to what would be produced by burning a few milliliters of diesel fuel, although the hydrogen ignition would occur in a fraction of a second. No significant dryout or boiling of sludge would occur. In that respect the consequence of a hydrogen ignition event would be similar to the LDC overpressurization event previously analyzed in Section 3.4.5. The ARF and RF in that section was taken from DOE-HDBK-301094 (1994) Section 4.4.2.2.2 and is stated to be "conservative for the suspension of a powder from a smooth unyielding surface from the pressure impulse generated (i.e., gas flow parallel to surface) by an explosion." The recommended bounding values are 5.0E- 03 and 0.3 for the ARF and RF, respectively. That evaluation (Section 3.4.5) resulted in a release of $270 \mathrm{~g}$ of respirable sludge aerosol.

DOE-HDBK-3010-94 Section 4.1 also suggests modeling an explosive-type release as that which most closely resembles three different stresses; shock, blast, or venting of pressurized gas. For shock effects the handbook states "For detonations in or contiguous to solid material, a respirable release of the mass of inert material equal to the calculated TNT equivalent is assessed to be bounding." The heat of combustion of hydrogen is $7.09 \times 10^{4} \mathrm{~J} / \mathrm{g}$-mole $\left(6.1 \times 10^{4} \mathrm{Btu} / \mathrm{lb}\right)$ at standard temperature and pressure according to Avallone and Baumeister (1987), Marks' Standard Handbook for Mechanical Engineers. According to Crowl and Louvar (1990) 
Chemical Process Safety: Fundamentals with Applications, the heat of combustion of TNT is $4,773 \mathrm{~J} / \mathrm{g}(1,140 \mathrm{cal} / \mathrm{g})$. Thus the TNT equivalent for hydrogen is $59.3 \mathrm{~g} / \mathrm{g}$-mole. A $15 \%$ mixture of hydrogen in the LDC contains 14 moles per Appendix B. The TNT equivalent is $14.5 \mathrm{~g}$-mole multiplied by $59.3 \mathrm{~g} / \mathrm{g}$-mole, which equals $859 \mathrm{~g}$ TNT. Given the $859 \mathrm{~g}$ TNT equivalent, the respirable release would be $859 \mathrm{~g}$ of sludge aerosol. Blast effects apply more to aggregate that is hurled which is not representative of the scenario under consideration. Although useful as a comparison this approach is judged to be overly conservative since it applies to an open-air explosion when in fact the LDC would remain intact. This model will not be used.

Section 3.4.5.2 shows a respirable release of $270 \mathrm{~g}$ for a high pressure venting of the LDC due to overpressure accidents. This release is based on an ARF and RF taken from DOE-HDBK-301094, Section 4.4.2.2.2. This discusses experiments involving large volume, confined deflagrations. The ARF is $5 \mathrm{E}-03$; the $\mathrm{RF}$ is 0.3 .

As a final comparison, an analysis of hydrogen deflagrations in LDCs at T Plant was performed and documented in HNF-12563 Section 6.6. The T Plant analysis used a computer code called HANSF, which includes models for entrainment of aerosol from the sludge filters, and aerosol removal mechanisms in the headspace above the sludge. The amount of aerosol released from the LDC into the T Plant railroad tunnel in the base case was $73 \mathrm{~g}$ (HNF-12563 Table 11). HNF-12563 Table 12 shows the release as a function of burn duration. If the burn duration is halved, the release out of the LDC is $240 \mathrm{~g}$. IF it is doubled, the release is about $10 \mathrm{~g}$.

The respirable release used in the deflagration analysis is $270 \mathrm{~g}$, the value obtained using ARF and RF from DOE-HDBK-3010-94 and which bounds the base case T Plant analysis and the burn duration sensitivity analysis results.

\section{Detonation in an Unpressurized LDC}

There could be a condition in which the cask and LDC are, for some reason, not pressurized when the burn occurs. This could occur if the cask seals inadvertently leak when the LDC and cask are being prepared for shipping. Should this happen, the peak LDC pressure for a detonation in air is 15.9 atm or 234 psia (from FM 99-5). When this value is multiplied by 2 (the dynamic load factor), the equivalent peak pressure is 468 psia. This is below the LDC burst pressure in Appendix C. The release from hydrogen detonation in an LDC that remains intact is calculated in HNF-12563. The release is bounded by a value of $570 \mathrm{~g}$ (Table $19 \mathrm{of} \mathrm{HNF-12563).}$

\section{Partial Decant}

The partial decant case is discussed next.

In the partial decant case, the volumes are small and do not encompass the filter structure. Therefore, there are no obstacles to accelerate the flame. As a result, per the arguments above, there is no detonation. The release is negligible as the water level covers the sludge filled filters. There is sludge in the water but little gas. Therefore, the water is essentially incompressible. The peak pressure, however, is above the design and hydro test pressure of the LDC but below the burst pressure. Since the volumes are small, the dynamic effect should not be great. Therefore, a dynamic load factor of 2 appears to be overly conservative. The ports however, will 
fail resulting in a 2 inch and 3 inch diameter openings within the LDC. Appendix C shows that the LDC will not fail.

The previous section discussed the effects of a detonation above the liquid surface. The release was calculated to be $2.7 \mathrm{~kg}$. The basis for the model was the effect of dissolved gases in the sludge. Since in this case, the liquid has been stirred by a retrieval, which is prior to, or on-going when the partial decant occurs, there will not be much gas in the liquid. Therefore, the release will be less. Since there is no detonation either, it is judged that the liquid/sludge release is 0.1 of that for the detonation with gas pockets below the surface or $270 \mathrm{~g}$ wet sludge.

\section{Air in the Treated Water System}

This case is bounded by the detonation accidents discussed above in the case where the LDC headspace volume is large and is the same as the Partial Decant case when the headspace volume is small. Therefore consequences from this specific event will not be presented.

Table 3-27. Hydrogen Burn Source Term Summary

\begin{tabular}{|l|l|}
\hline \multicolumn{1}{|c|}{ Case } & \multicolumn{1}{|c|}{ Respirable Release } \\
\hline $\begin{array}{l}\text { 1200 L Headspace, 30\% hydrogen (detonation), LDC at 1.68 atm before } \\
\text { hydrogen accumulation (Appendix B, Case 2) }\end{array}$ & $\begin{array}{l}10 \mathrm{~kg} \text { - breached facility case } \\
1.2 \mathrm{~kg} \text { - intact facility case }\end{array}$ \\
\hline 1200 L Headspace, 15\% Hydrogen (Deflagration) (Appendix B, Case 4) & $270 \mathrm{~g}$ \\
\hline $\begin{array}{l}\text { 1200 L Headspace, 30\% Hydrogen (Detonation), LDC at atmospheric } \\
\text { pressure }\end{array}$ & $570 \mathrm{~g}$ \\
\hline Partial Decant (air atmosphere) & $270 \mathrm{~g}$ \\
\hline
\end{tabular}

\subsubsection{Consequence Analysis}

The doses cannot be calculated with RADIDOSE (DOE/RL-2002-50), as RADIDOSE does not have the ARF and RF for accidents involving $K$ Basin sludge. Instead, the doses will be calculated by hand using the formula and data from RADIDOSE and the release source terms calculated above.

All consequence analyses are performed assuming that the LDC and cask are inside the K Basins structure. The only conditions in which an LDC and cask could be outside the structure is if it meets the conditions for shipping. Therefore, all outside-the-structure analyses fall under the Transportation Package Safety Analysis Assessment (PSAA) (SNF-10823, Package Safety Analysis Assessment for Sludge Transportation System).

\section{$\chi / \mathbf{Q}^{\prime}$ calculation}

The atmospheric dispersion factor $\left(\chi / \mathrm{Q}^{\prime}\right)$ was calculated hydrogen detonation-type failure of the LDC/cask system after loading with KE Basin sludge. This calculation carried out using the GXQ code version 4.0F (WHC-SD-GN-SWD-30002). For the case where the detonation is postulated inside an intact structure, the MACCS building wake model was used. For the case where the detonation is postulated in a breached structure, the initial plume model was used to account for the calculated initial plume size (height and width) of the release ( $86 \mathrm{~m}$ tall, $10 \mathrm{~m}$ wide). 
Three cases were analyzed: (1) a detonation failure of the LDC/cask system inside the intact loading facility at $\mathrm{KE}$ Basin, (2) a detonation failure of the LDC/cask system that breaches the KE Basin facility, and (3) a less energetic release from a deflagration or a detonation from a LDC at atmospheric pressure. In addition, the plume depletion model from RPP-11482, Atmospheric Dispersion Coefficients and Radiological and Toxicological Exposure Methodology for Use in Tank Farms has been used for receptors beyond $100 \mathrm{~m}$. The deposition velocity used in the depletion analysis is $0.15 \mathrm{~cm} / \mathrm{s}$ taken from Section 2.3 .1 of RPP-11482. The details and results of these cases follow. These $\chi / Q$ 's are $95^{\text {th }}$ percentile worst-cases integrated over all 16 sectors at $100 \mathrm{~m}$ using 100 area meteorology records averaged over 9 years. $\chi / Q$ s for specific directions are 99.5 th percentile worst-case for that direction.

1. In case 1 , the $\mathrm{LDC} /$ cask system is assumed to be located inside the loading facility at $\mathrm{KE}$ Basin with the bay door shut. The release from the event is assumed to escape from multiple points on the exterior of the facility without filtration. The release is an area source, as it is forced out of the many openings in the building. The size of the building is given as $25 \mathrm{ft}(7.6 \mathrm{~m})$ high by $90 \mathrm{ft}(27.4 \mathrm{~m})$ wide.

2. In case 2, the $\mathrm{LDC} /$ cask system is assumed to be located inside $\mathrm{KE}$ Basin. A hydrogen deflagration with catastrophic failure of the LDC/cask system is assumed to open a large hole in the ceiling. The plume rises unimpeded. It was determined in Section 3.4.7.2 that the detonation with catastrophic failure produced a plume $86 \mathrm{~m}$ high (due to thermal rise) and $10 \mathrm{~m}$ wide (due to lateral spreading). A lesser event than the one analyzed could produce a smaller plume, but the analysis predicts that the release would be proportional to the initial volume of the plume. A larger plume is therefore a worse case.

3. The $\chi / Q^{\prime}$ for the less energetic releases used the values from the past safety analyses as the plume rise would be very small. These values are taken from Section 3.3.2.3. In these cases, credit is not taken for the presence of the building that encloses the basin. This is a typical assumption in an unmitigated accident analysis when the release is a point source with low energy.

The values of $\chi / Q^{\prime}$ are shown below. The GXQ runs are provided in Appendix D.

Table 3-28. $\chi / \mathrm{Q}^{\prime}$ for Hydrogen Burn in LDC, $\mathrm{s} / \mathrm{m}^{3}$

\begin{tabular}{|l|l|l|l|l|}
\hline Case & $\begin{array}{l}\text { Onsite }(100 \mathrm{~m}, \\
\text { all sectors })\end{array}$ & $\begin{array}{l}\text { Near River } \\
(520 \mathrm{~m} \mathrm{~W})\end{array}$ & $\begin{array}{l}\text { Firehouse } \\
(3750 \mathrm{~m} \text { ESE })\end{array}$ & $\begin{array}{l}\text { Offsite } \\
(10,070 \mathrm{~m} \mathrm{~W})\end{array}$ \\
\hline $\begin{array}{l}\text { Detonation in } \\
\text { Intact Structure }\end{array}$ & $8.10 \mathrm{E}-03$ & $1.71 \mathrm{E}-03$ & $9.91 \mathrm{E}-05$ & $1.69 \mathrm{E}-05$ \\
\hline $\begin{array}{l}\text { Detonation in } \\
\text { Breached Structure }\end{array}$ & $1.60 \mathrm{E}-03$ & $4.74 \mathrm{E}-04$ & $7.17 \mathrm{E}-05$ & $2.28 \mathrm{E}-05$ \\
\hline $\begin{array}{l}\text { Other 3 Cases } \\
\text { (Deflagration, } \\
\begin{array}{l}\text { Partial decant and } \\
\text { Detonation with } \\
\text { LDC at } \\
\text { atmospheric } \\
\text { pressure) }\end{array}\end{array}$ & $7.32 \mathrm{E}-02$ & $3.55 \mathrm{E}-03$ & $1.60 \mathrm{E}-04$ & $4.49 \mathrm{E}-05$ \\
\hline
\end{tabular}


The dose is found using Equation 3-2 and the breathing rate and UD from Section 3.3.2. The $\chi / \mathrm{Q}$ 's are given above. The source terms are derived in Section 3.4.7.2 and shown in Table 3-27. Table 3-29a uses the 10-kg source term for the pressurized detonation case. This table uses the $\chi / Q^{\prime}$ for detonation in a breached structure, which is the worse of the two detonations in a pressurized LDC cases.

Table 3-29a. Dose Consequences for Hydrogen Burn within LDC $30 \%$ Hydrogen (detonation in LDC, LDC and cask fail, breached structure case)

\begin{tabular}{|l|c|c|c|}
\hline \multicolumn{1}{|c|}{$\begin{array}{c}\text { Receptor location } \\
\text { (distance, direction) }\end{array}$} & \multicolumn{2}{|c|}{ Unmitigated } & $\begin{array}{c}\text { Evaluation guidelines } \\
\text { (rem) }\end{array}$ \\
\cline { 2 - 4 } & $\chi / \mathbf{Q}^{\prime}$ & Rem & 25 to 100 \\
\hline $\begin{array}{l}\text { Onsite } \\
(100 \mathrm{~m}, \mathrm{E})\end{array}$ & $1.60 \mathrm{E}-03$ & $8.1 \mathrm{E}+01$ & -- \\
\hline $\begin{array}{l}\text { Columbia River, near bank } \\
(520 \mathrm{~m}, \mathrm{~W})\end{array}$ & $4.74 \mathrm{E}-04$ & $3.9 \mathrm{E}+01$ & -- \\
\hline $\begin{array}{l}100 \text { Area Fire Station } \\
(3,750 \mathrm{~m}, \text { ESE) }\end{array}$ & $7.17 \mathrm{E}-05$ & $3.6 \mathrm{E}+00$ & 1 to 25 \\
\hline $\begin{array}{l}\text { Hanford Site boundary } \\
(10,070 \mathrm{~m}, \mathrm{~W})\end{array}$ & $2.28 \mathrm{E}-05$ & $1.9 \mathrm{E}+00$ & \\
\hline
\end{tabular}

Table $3-29 \mathrm{~b}$ uses the $1.2-\mathrm{kg}$ source term and the $\chi / \mathrm{Q}^{\prime}$ for detonation in an intact structure.

Table 3-29b. Dose Consequences for Hydrogen Burn within LDC $30 \%$ Hydrogen (detonation in LDC, LDC and cask fail, intact structure case)

\begin{tabular}{|c|c|c|c|}
\hline \multirow{2}{*}{$\begin{array}{l}\text { Receptor location } \\
\text { (distance, direction) }\end{array}$} & \multicolumn{2}{|c|}{ Unmitigated } & \multirow{2}{*}{$\begin{array}{l}\text { Evaluation guidelines } \\
\text { (rem) }\end{array}$} \\
\hline & $\chi / \mathbf{Q}^{\prime}$ & Rem & \\
\hline $\begin{array}{l}\text { Onsite } \\
(100 \mathrm{~m}, \mathrm{E})\end{array}$ & $8.10 \mathrm{E}-03$ & $4.9 \mathrm{E}+01$ & 25 to 100 \\
\hline $\begin{array}{l}\text { Columbia River, near bank } \\
(520 \mathrm{~m}, \mathrm{~W})\end{array}$ & $1.71 \mathrm{E}-03$ & $1.7 \mathrm{E}+01$ & -- \\
\hline $\begin{array}{l}100 \text { Area Fire Station } \\
(3,750 \mathrm{~m}, \mathrm{ESE})\end{array}$ & $9.91 \mathrm{E}-05$ & $6.0 \mathrm{E}-01$ & -- \\
\hline $\begin{array}{l}\text { Hanford Site boundary } \\
(10,070 \mathrm{~m}, \mathrm{~W})\end{array}$ & $1.69 \mathrm{E}-05$ & $1.7 \mathrm{E}-01$ & 1 to 25 \\
\hline
\end{tabular}

Table 3-30 uses the 570-g source term and appropriate $\chi / \mathrm{Q}^{\prime}$ for atmospheric pressure detonation. 
Table 3-30. Dose Consequences for Hydrogen Burn within LDC' $30 \%$ Hydrogen (detonation in unpressurized LDC)

\begin{tabular}{|c|c|c|c|}
\hline \multirow{2}{*}{$\begin{array}{c}\text { Receptor location } \\
\text { (distance, direction) }\end{array}$} & $\chi / \mathbf{Q}^{\prime}$ & Unmitigated & $\begin{array}{c}\text { Evaluation } \\
\text { guidelines } \\
\text { (rem) }\end{array}$ \\
\cline { 2 - 4 } & $7.32 \mathrm{E}-02$ & $2.1 \mathrm{E}+02$ & 25 to 100 \\
\hline $\begin{array}{c}\text { Onsite } \\
(100 \mathrm{~m}, \mathrm{E})\end{array}$ & $3.55 \mathrm{E}-03$ & $1.7 \mathrm{E}+01$ & -- \\
\hline $\begin{array}{c}\text { Columbia River, near bank } \\
(520 \mathrm{~m}, \mathrm{~W})\end{array}$ & $1.60 \mathrm{E}-04$ & $4.6 \mathrm{E}-01$ & -- \\
\hline $\begin{array}{c}100 \text { Area Fire Station } \\
(3,750 \mathrm{~m}, \mathrm{ESE})\end{array}$ & $4.49 \mathrm{E}-05$ & $2.1 \mathrm{E}-01$ & 1 to 25 \\
\hline $\begin{array}{c}\text { Hanford Site boundary } \\
(10,070 \mathrm{~m}, \mathrm{~W})\end{array}$ & & \\
\hline Note 1: No credit for building wake or leak path factor. & \\
\hline
\end{tabular}

Table 3-31 uses the 270-g source term and $\chi / \mathrm{Q}^{\prime}$ for the deflagration case. These parameters also apply to the partial decant case.

Table 3-31. Dose Consequences of a Deflagration or Partial Decant

\begin{tabular}{|c|c|c|c|}
\hline \multirow{2}{*}{$\begin{array}{c}\text { Receptor location } \\
\text { (distance, direction) }\end{array}$} & $\chi / \mathrm{Q}^{\prime}$ & Rem $^{\mathbf{1}}$ & $\begin{array}{c}\text { Unaluation } \\
\text { guidelines } \\
\text { (rem) }\end{array}$ \\
\cline { 2 - 4 } & $7.32 \mathrm{E}-02$ & $9.9 \mathrm{E}+01$ & 25 to 100 \\
\hline $\begin{array}{c}\text { Onsite } \\
(100 \mathrm{~m}, \mathrm{E})\end{array}$ & $3.55 \mathrm{E}-03$ & $7.9 \mathrm{E}+00$ & -- \\
\hline $\begin{array}{c}\text { Columbia River, near bank } \\
(520 \mathrm{~m}, \mathrm{~W})\end{array}$ & $1.60 \mathrm{E}-04$ & $2.2 \mathrm{E}-01$ & -- \\
\hline $\begin{array}{l}100 \text { Area Fire Station } \\
(3,750 \mathrm{~m}, \mathrm{ESE})\end{array}$ & $4.49 \mathrm{E}-05$ & $1.0 \mathrm{E}-01$ & 1 to 25 \\
\hline $\begin{array}{c}\text { Hanford Site boundary } \\
(10,070 \mathrm{~m}, \mathrm{~W})\end{array}$ & & \\
\hline \multicolumn{2}{|l}{ Note 1: No credit taken for building wake or leak path factor. } \\
\hline
\end{tabular}

The worst case onsite dose is the "detonation within an unpressurized LDC" case. In this case the LDC remains intact, so there is no plume expansion as a result of the energy liberated when the LDC and cask fail.

The worst case offsite dose comes from the "detonation in a pressurized LDC" in a breached structure.

\subsubsection{Comparison to Guidelines}

The offsite doses for the detonation cases are in the dose region where safety class controls must be considered ( 1 to 25 rem offsite). It is judged that no safety class designation need be made due to a number of conservatisms in the consequence analysis. They are: 
- The analysis assumptions (use of 60:40 sludge, ignition at 30\% hydrogen in cask and LDC, $100 \%$ of sludge on sludge filters is suspended) are conservative.

- It is assumed that $181 \mathrm{~kg}$ of sludge accumulates on the filters. This value is based on the loading without backwash. With backwash, the filter loading is no greater than half that used in the analysis.

- A detonation in the LDC is assumed. Section 3.4.7 shows that a detonation would probably not occur, as the length of the LDC is not sufficient for a deflagration to transition to a detonation.

- The LDC is assumed to fail catastrophically. Appendix C shows that the likely failure mode is a split in a seam in the cylindrical shell of the LDC. The head will not come off.

The unmitigated frequency is found next.

In this case a fill gas that is an oxidizer (e.g., air) is used instead of argon. The detonation case requires a large hydrogen concentration. Due to the short length of the LDC, the mole fraction must be very close to 0.3 . Detonations can occur with hydrogen mole fractions down to 0.13 to 0.15 but as was shown in NUREG/CR-5275 the distances needed to transition to a detonation is much greater than any LDC dimension. To reach a mole fraction of 0.3 requires a full LDC and a wait of a long period of time based on SNF-18133.

The combination of long wait time, lack of an obvious spark source, and ignition only at the optimal time and not at any time prior to reaching a mole fraction of 0.3 and lack of doing something about the hydrogen accumulation in air is judged to make this event Unlikely.

The case with $15 \%$ hydrogen when argon is not used as the cover gas does not require as long a wait and is given a frequency of Anticipated.

The partial decant cases, without argon as the cover gas, are considered to be Unlikely. This is because with argon present, a flammable condition does not exist (except after a long period of time in very small volumes). Therefore, for this condition to exist, there needs to be a failure to have argon present in the headspace and the concurrent independent failure that caused the partial decant.

The treated water system purge failure (air left in system) (Group 2 accidents) and LDC open during disconnect (Group 3 accidents) are Extremely Unlikely because of the long time to achieve flammable conditions (Group 3) or the large length of piping that must be air filled (and the system still operate). The onsite dose is classified as high. Given this, the Risk Class is II.

This is summarized in Table 3-32. 
Table 3-32. Hydrogen Burn Consequence Summary

\begin{tabular}{|l|l|l|l|}
\hline \multicolumn{1}{|c|}{ Case } & \multicolumn{1}{|c|}{ Frequency } & \multicolumn{1}{|c|}{ Consequences } & \multicolumn{1}{|c|}{ Risk } \\
\hline $\begin{array}{l}\mathrm{H}_{2} \text { Detonation in breached } \\
\text { structure }\end{array}$ & Unlikely & $\begin{array}{l}\text { Onsite: Moderate } \\
\text { Offsite: Moderate }\end{array}$ & $\begin{array}{l}\text { Onsite: II } \\
\text { Offsite: II }\end{array}$ \\
\hline $\mathrm{H}_{2}$ Deflagration & Anticipated & $\begin{array}{l}\text { Onsite: High } \\
\text { Offsite: Low }\end{array}$ & $\begin{array}{l}\text { Onsite: I } \\
\text { Offsite: III }\end{array}$ \\
\hline $\begin{array}{l}\text { Detonation in LDC } \\
\text { at Atmospheric Pressure }\end{array}$ & Unlikely & $\begin{array}{l}\text { Onsite: High } \\
\text { Offsite: Low }\end{array}$ & $\begin{array}{l}\text { Onsite: I } \\
\text { Offsite: III }\end{array}$ \\
\hline Partial Decant & Unlikely & $\begin{array}{l}\text { Onsite: High } \\
\text { Offsite: Low }\end{array}$ & $\begin{array}{l}\text { Onsite: I } \\
\text { Offsite: III }\end{array}$ \\
\hline
\end{tabular}

Table 3-33 presents a summary of the entire analysis:

Table 3-33. Unmitigated Accident Summary Table

\begin{tabular}{|c|c|c|c|c|c|c|c|c|c|c|c|c|}
\hline \multirow[b]{2}{*}{ Scenario } & \multirow[b]{2}{*}{ Freq. } & \multirow[b]{2}{*}{$\begin{array}{c}\text { MAR } \\
(\mathrm{kg})\end{array}$} & \multirow[b]{2}{*}{ DR } & \multirow[b]{2}{*}{$\mathrm{ARF}$} & \multirow[b]{2}{*}{ RF } & \multirow[b]{2}{*}{ LPF } & \multicolumn{3}{|c|}{ Collocated Worker } & \multicolumn{3}{|c|}{$\begin{array}{l}\text { Maximum Offsite } \\
\text { Individual }\end{array}$} \\
\hline & & & & & & & $\begin{array}{c}x / Q \\
\left(\mathrm{~s} / \mathrm{m}^{3}\right) \\
\end{array}$ & $\begin{array}{l}\text { Dose } \\
\text { (rem) }\end{array}$ & $\begin{array}{l}\text { Risk } \\
\text { Class } \\
\end{array}$ & $\begin{array}{c}\chi / Q \\
\left(\mathrm{~s} / \mathrm{m}^{3}\right)\end{array}$ & $\begin{array}{l}\text { Dose } \\
\text { (rem) }\end{array}$ & $\begin{array}{l}\text { Risk } \\
\text { Class }\end{array}$ \\
\hline $\begin{array}{l}\text { Detonation in } \\
\text { Pressurized } \\
\text { LDC, breached } \\
\text { facility }\end{array}$ & $\mathrm{U}$ & 181 & 1.0 & $5.5 \mathrm{E}-2^{1}$ & 1 & 1 & $1.60 \mathrm{E}-3$ & 81 & II & $2.28 \mathrm{E}-5$ & 1.9 & II \\
\hline $\begin{array}{l}\text { Deflagration in } \\
\text { Pressurized } \\
\text { LDC }\end{array}$ & A & 181 & 1.0 & $3.2 \mathrm{E}-3^{1}$ & 1 & 1 & $7.32 \mathrm{E}-2$ & 99 & I & $4.49 \mathrm{E}-5$ & 0.10 & III \\
\hline $\begin{array}{l}\text { Detonation in } \\
\text { LDC at } \\
\text { Atmospheric } \\
\text { Pressure }\end{array}$ & $\mathrm{U}$ & 181 & 1.0 & $3.2 \mathrm{E}-3^{1}$ & 1 & 1 & $7.32 \mathrm{E}-2$ & 210 & $\mathrm{I}$ & $4.49 \mathrm{E}-5$ & 0.21 & III \\
\hline Partial Decant & $\mathrm{U}$ & 181 & 1 & $1.5 \mathrm{E}-3^{1}$ & 1 & 1 & $7.32 \mathrm{E}-2$ & 99 & I & $4.49 \mathrm{E}-5$ & 0.10 & III \\
\hline
\end{tabular}




\subsubsection{Mitigation and Prevention Analyses}

\section{Mitigators and Preventors}

The analysis shows the following:

1. Argon or some other inert or non-reacting gas that is much heavier than air must be used instead of a gas that can chemically react with hydrogen and/or oxygen or that can oxidize hydrogen (i.e., hydrogen "burns" in it) or is lighter than air. The analysis was based on use of argon. Different gases that meet the criteria will produce somewhat different burn pressures but the unmitigated results will be similar. The criterion for heavier than air is implicit in the hazard identification task which assumed a gas (argon) that was much heavier than air. The inert gas is used to prevent deflagrations or detonations for the accidents in the other groups. The function of the gas is to:

- inert the LDC under all operating and storage conditions at $\mathrm{K}$ Basin including normal decants and off-normal partial decants.

- maintain the LDC inert when the vent filters are on and the LDC is in the cask.

2. For worker safety, the transfer lines should be filled with the inert gas or water so that hydrogen does not enter an air filled line.

3. Other controls that are needed to prevent hydrogen burns for the other groups of hazards are:

- the ports on the LDC must be closed prior to $1.25 \%$ oxygen environment ( $25 \%$ of the minimum oxygen concentration needed for flammability) being formed in the LDC due to air ingress.

- the Treated Water System is purged of air after maintenance

- the vent filters must be placed on the LDC (which must contain an inert environment) prior to $1.25 \%$ oxygen environment being formed in the LDC due to air ingress.

4. In some special partial decant cases, air can enter the system through leaks in the line. This can only occur if the argon system is not keeping the LDC pressurized. Appendix C shows that ignition of hydrogen and oxygen build up in a $400 \mathrm{~L}$ (or less) headspace above the liquid does not result in LDC failure. It is possible that the hoses might blow out under these conditions. To prevent this event, either argon must pressurize the LDC in all partial decant situations identified by the Hazard Identification and Evaluation analysis, or a stress analysis performed that shows that the hoses do not fail. 


\section{Mitigated Accident Analysis}

The first mitigator is the leak path factor (LPF) of the building. As was discussed above, all the accidents analyzed occur within the $\mathrm{K}$ Basins building. The cases of "detonation in a pressurized LDC" are already analyzed more realistically, and have the effects of the presence of the building included. This mitigated analysis is for the other cases: Deflagration, Detonation in an Unpressurized LDC, and Partial Decant.

The LPF is taken from HNF-1777 using the FLUENT code, as described in Section 3.4.5.4, and found to be 0.5 . This value is less than that typically calculated. Typically a lumped parameter, perfectly mixed volume calculation is performed. Typical leak path factors are in the range of 0.84 (see Appendix 9C of HNF-SD-CP-SAR-021, Plutonium Finishing Plant Final Safety Analysis Report). However, these analyses do not model the eddies, flow towards the floor, or the pool surface, that cause a reduction in the LPF over that from a perfectly mixed, non-detailed analysis.

The actual LPF is even smaller because neither the lumped parameter model nor the 2-D FLUENT model includes the many pieces of equipment in the facility and on the STS trailer, which can act to intercept particles or can act as surfaces on which the particles can settle. Neither model accounts for the liquid that likely comes out with the sludge, which acts as a particle removal mechanism (particles "stick" to wet surfaces). Neither model accounts for the fact that the release is not of a small opening which will tend to enhance agglomeration.

A LPF of 0.5 will be used in this analysis. A TSR control on keeping the building doors closed is needed. Use of this LPF results in the following mitigated consequences:

\begin{tabular}{|l|l|l|}
\hline \multicolumn{3}{|c|}{ Consequences Assuming LPF of 0.5 } \\
\hline Case & Onsite, rem & Offsite, rem \\
\hline Detonation in Unpressurized LDC & 105 & 0.1 \\
\hline Deflagration & 50 & 0.05 \\
\hline Partial Decant & 50 & 0.05 \\
\hline $\begin{array}{l}\text { Note 1: Consequences of the "detonation in a pressurized LDC" do not change as } \\
\text { the effect of the building is already included. }\end{array}$ \\
\hline
\end{tabular}

Using argon as an inert gas prevents most accidents of the type analyzed in this section. According to SNF-18133, initially, only hydrogen will be transported into the headspace as the oxygen reacts chemically with uranium metal and $\mathrm{UO}_{2}$. SNF-18133 shows that no oxygen enters the headspace. As a result, no flammable conditions will be created within the LDC. The accident is prevented.

If conditions change such that oxygen is transported into the headspace, (an extremely unlikely event per SNF-18133), chemical generation of hydrogen has also begun. The hydrogen generation rate will be much greater than the oxygen generation rate. This will result in a much 
larger hydrogen to oxygen ratio within the headspace. As a result, if a spark source is present, a deflagration will be the most likely result; not a detonation (which requires a ratio of 2:1). As shown above, both the onsite and offsite consequences of a deflagration are a factor of 2 less than those of a detonation.

If the failure is such that air enters the LDC, it will no longer be pressurized. In addition, in most cases, the majority of the headspace will still contain argon (with air mixed in). Since there will be little oxygen, a detonation will likely not occur should a flammable condition be formed and a spark source exist. As shown above, even if enough air enters the system and displaced most of the argon, and a detonation occurs, the LDC is not breached as it is initially at atmospheric pressure. The respirable releases and doses for a detonation within the LDC that is not pressurized are about double those of a deflagration.

It is seen that the controls listed above lower the frequency of an accident as well as the consequences.

The mitigated event has a frequency of Extremely Unlikely for all accidents, except the deflagration accident, which has a frequency of Unlikely, based on the unmitigated frequency discussion above. The frequency bin reduction taken for the AIVS system. A bin reduction is justified as the AIVS is an Engineered Safety Feature covered by a TSR with surveillances to assure operability and availability. The other process controls are assumed to support the one bin reduction in frequency. The mitigated Risk Bin is shown below.

\begin{tabular}{|c|c|c|c|}
\hline \multicolumn{4}{|c|}{ Mitigated Risk ${ }^{1}$} \\
\hline Case & Frequency & $\begin{array}{c}\text { Onsite Risk } \\
\text { Bin }\end{array}$ & $\begin{array}{c}\text { Offsite Risk } \\
\text { Bin }\end{array}$ \\
\hline \multicolumn{4}{|l|}{ Detonation in Pressurized LDC } \\
\hline Breached facility & EU & III & III \\
\hline Intact facility & $\mathrm{EU}$ & III & IV \\
\hline Deflagration & $\mathrm{U}$ & II & III \\
\hline Detonation in LDC at Atmospheric Pressure & EU & II & IV \\
\hline Partial Decant & EU & III & IV \\
\hline \multicolumn{4}{|c|}{ Note 1: Taking credit for LPF of 0.5 for all but the "detonation in a pressurized LDC" accident and one bin } \\
\hline
\end{tabular}

As discussed in Section 3.4.5.5, two other factors in addition to the LPF, for which credit is not specifically taken, can serve to reduce the dose. These are allowing for a building wake $\chi / \mathrm{Q}^{\prime}$ instead of point source, and assuming a sludge filter loading of $91 \mathrm{~kg}$ instead of $181 \mathrm{~kg}$. Use of the $91-\mathrm{kg}$ loading will decrease the Deflagration case by a factor of 2 . The detonation cases do not decrease because agglomeration and settling are considered. If only half as much aerosol is suspended, the initial volume concentration decreases by a factor of 2 . Since the plume is less 
dense, less will agglomerate and settle. The respirable release is generally the same if $91 \mathrm{~kg}$ are deposited on the sludge filters as if $181 \mathrm{~kg}$ were deposited. Use of building wake $\chi / \mathrm{Q}^{\prime}$ will decrease the dose in the Deflagration case, the Detonation in an Unpressurized LDC case, and the Partial Decant case by as much as a factor of 9 (see section 3.4.5.4).

\subsubsection{Summary of Safety Structures, Systems, and Components and Technical Safety Requirement Controls}

As was argued in Section 3.4.7.4, there are no safety class structures, systems or components.

Safety-significant SSCs include:

- Active Inert Ventilation System as described in Section 3.4.6.6. The AIVS reduces the frequency of a hydrogen burn accident by providing an oxygen-deficient environment in the LDC headspace.

- LDC inlet deflector plate as described in Section 3.4.3.5. The deflector plate protects the analysis assumption of sludge content.

- LDC pressure boundary as described in Section 3.4.3.5. The LDC pressure boundary confines the argon gas provided by the AIVS and prevents the ingress of air to maintain an inert atmosphere in the LDC, thereby reducing the frequency of a hydrogen burn.

- Strainer basket as described in Section 3.4.3.5. The strainer basket protects the analysis assumptions with regard to sludge content.

Safety-significant TSR controls include:

- AIVS operability LCO as described in Section 3.4.6.6. This ensures the AIVS can perform its safety function of providing an oxygen-deficient environment in the LDC headspace.

- Sludge retrieval administrative controls as described in Section 3.4.3.5. This protects source term assumptions used in the analysis.

- Additional sludge retrieval and shipment preparation controls relating to hydrogen accumulation as described in Section 3.4.6.6. These reduce the frequency of the hydrogen burn accident.

- Maintain doors nearest to LDC closed at all times. Doors on the opposite end of the building from the LDC can be opened for short periods of time.

\subsubsection{Fire Directly Impacting Sludge and Water System Equipment}

Fire could impact the SWS equipment both directly and indirectly. The potential indirect impacts resulting from fire-related structural failures and associated equipment drops are 
discussed in Section 3.4.9. This section examines the possibility of a radiological release as the result of a fire in the KE Basin directly involving the SWS.

\subsubsection{Scenario Development}

The direct impact of a fire on the Sludge Transportation System is analyzed in SNF-10415, Design-Basis Thermal and Gas Generation Analysis for KE Basin Sludge in Large Diameter Containers. The specifications of the fire conform to the standard performance test requirements of Title 10, Code of Federal Regulations, Part 71, "Packaging and Transportation of Radioactive Material" (10 CFR 71), Section 71.73. In summary, these criteria are as follows:

- Exposure of the specimen fully engulfed in a hydrocarbon fuel-air fire of sufficient extent to provide an average emissivity coefficient of at least 0.9 , with an average flame temperature of at least $800^{\circ} \mathrm{C}\left(1,475^{\circ} \mathrm{F}\right)$ for a period of 30 minutes

- Fuel source extending horizontally at least $1 \mathrm{~m}$ with the specimen positioned $1 \mathrm{~m}$ above the surface of the fuel source

- Surface absorptivity coefficient the greater of 0.8 or the published value at temperature.

Using the criteria above and taking no credit for convection within the sludge, the analysis in SNF-10415 leads to the conclusion that 3\% of the sludge volume could reach boiling temperature for about 10 minutes. This analysis conservatively neglects the latent heat of vaporization of water in the sludge. Per HNF-SD-SNF-FHA-001, Fire Hazards Analysis for the $K$ Basins Facilities at $100 \mathrm{~K}$ Area the fire specified in 10 CFR 71.73 exceeds the severity of either the unmitigated accidental fire (16 transporter tires plus 100 gal diesel fuel) or credible bounding accidental fire ( 16 transporter tires plus 7.5 gal diesel fuel) in terms of peak-sustained temperature. It is judged overall that use of the 10 CFR 71.73 fire definition provides a conservative basis for deriving an unmitigated source term.

\subsubsection{Source Term Analysis}

The MAR is $60 \mathrm{~L}$, which is $3 \%$ of the $2 \mathrm{~m}^{3}$ payload of settled sludge. Since only $3 \%$ of the sludge reaches boiling temperature, an ARF based on heating a liquid, as opposed to bulk boiling of a liquid, is appropriate. Table 3-1 of DOE-HDBK-3010-94 provides a list of ARFs as a function of temperature and air velocity for liquids approaching boiling, with an upper bound of $3.0 \times 10^{-5}$ at $100^{\circ} \mathrm{C}$ and $0.5 \mathrm{~m} / \mathrm{s}$ surface air velocity over a release time of 2 hours. Since the sludge is contained, it is anticipated that air velocities would be low. Since the size distribution of the airborne materials was not measured, a conservative RF of 1 is used. The source term is then $1.8 \mathrm{~mL}$ of respirable sludge material. The DR and LPF also are assumed to be 1 . This source term is very close to the source terms developed in HNF-6964, Safety Analysis for Spent Nuclear Fuel Sludge Storage at T Plant, for scenario B.6.4, "Fire in the Railroad Tunnel," which evaluates a fire engulfing the LDC in the T Plant railroad tunnel. The T Plant fire scenario also includes the effects of LDC overpressurization. 


\subsubsection{Consequence Analysis}

The vaporized sludge is vented to the environment in an acute release. The radiological consequences of this accident are calculated using the methodology described in Section 3.3, and the 1.8-mL source term described above. The results are shown in Table 3-34.

Table 3-34. Summary of Maximum Dose Consequences for Unmitigated Fire Engulfing Shipping Cask.

\begin{tabular}{|c|c|c|c|}
\hline \multirow{2}{*}{$\begin{array}{l}\text { Receptor location } \\
\text { (distance, direction) }\end{array}$} & \multicolumn{2}{|c|}{ Unmitigated } & \multirow{2}{*}{$\begin{array}{c}\text { Evaluation guidelines } \\
\text { (rem) }\end{array}$} \\
\hline & $\chi / Q^{\prime}$ & rem & \\
\hline $\begin{array}{l}\text { Onsite } \\
(100 \mathrm{~m}, \mathrm{E})\end{array}$ & $7.3 \mathrm{E}-02$ & $1.3 \mathrm{E}+00$ & 25 to 100 \\
\hline $\begin{array}{l}\text { Columbia River, near bank } \\
(520 \mathrm{~m}, \mathrm{~W})\end{array}$ & $3.6 \mathrm{E}-03$ & $1.0 \mathrm{E}-01$ & -- \\
\hline $\begin{array}{l}100 \text { Area Fire Station } \\
(3,750 \mathrm{~m}, \mathrm{ESE})\end{array}$ & $1.6 \mathrm{E}-04$ & $2.8 \mathrm{E}-03$ & -- \\
\hline $\begin{array}{l}\text { Hanford Site boundary } \\
(10,070 \mathrm{~m}, \mathrm{~W})\end{array}$ & $4.5 \mathrm{E}-05$ & $1.3 \mathrm{E}-03$ & 1 to 25 \\
\hline
\end{tabular}

Toxicological consequences are not calculated because they would be dominated not by the release of sludge material but by the combustion products and gasses released during the fire. An assessment of these hazards is beyond the scope of this analysis, but it is assumed that these consequences are significant and that appropriate preventative controls would be derived from the FHA.

\subsubsection{Comparison to Guidelines}

Radiological release consequences are "low" for the transportation performance-based test fire of 30-minute duration.

\subsubsection{Mitigation and Prevention Analyses}

The analyzed accident source term is based on an $800^{\circ} \mathrm{C}$ fire fully engulfing the Sludge Transportation System for 30 minutes per the 10 CFR 71.73 fire definition. According to SNF-8677, Fire Hazard Analysis for the K Basin Sludge and Water System Project, A-16, it is estimated that a fire of this duration would require the equivalent of at least 260 gal of diesel fuel, and still not be exceeded in temperature. The combustible inventory contained in the 16 trailer tires is $15.3 \mathrm{MJ}$, which is equivalent to $120 \mathrm{gal}$ of diesel fuel. Thus the combustible inventory of the transporter tires plus the 100 gallons from the tractor fuel tank still do not exceed the equivalent of a $260 \mathrm{gal}$ of diesel fuel which in turn is bounded the $800{ }^{\circ} \mathrm{C}$ fire in terms of peak temperature. Additionally there is not sufficient room for the tractor to enter the north transfer bay. Thus it is unlikely that all of the tractor fuel would contribute to the Sludge Transportation System fire. Based on the large amount of fuel needed to support a 30 minute engulfing fire and the lack of a sufficient fuel supply in any foreseen mission for the north transfer bay, and the expected radiological release consequences of this fire, which are well below evaluation guidelines, no TSR-level control on fuel tank inventory for any tractor used to position the Sludge Transportation System is warranted. 


\subsubsection{Summary of Safety Structures, Systems, and Components and Technical Safety Requirement Controls}

The sludge transportation cask is assumed to retain its integrity throughout the fire, but no SSCs are proposed to prevent or mitigate this accident.

TSR controls include the following ACs:

- Vehicle controls limit the quantity of diesel fuel to 100 gallons. This protects a bounding assumption of this analysis.

- Implementation of the Fire Protection Program provides general fire protection to reduce the probability of the accident.

\subsubsection{Fire Indirectly Impacting Sludge and Water System Equipment}

This section evaluates the potential hazardous consequences of a fire indirectly involving SWS or sludge transfer system SSCs. Consequences of direct impingement of the flame on the cask are addressed in Section 3.4.8.

\subsubsection{Scenario Development}

The postulated fire evaluated in HNF-SD-WM-SAR-062, Section 3.4.2.13, assumes ignition of 30 gal of diesel fuel contained in a forklift. It concludes that such a fire could damage column Bg-15 in about 5 minutes. This column supports the transfer bay bridge crane. If a fire damaged column Bg-15 to the extent that the transfer bay bridge crane fell, the crane could impact the shipping cask. Since the process shield plate is in place on the cask during sludge retrieval, the LDC would be protected from an impact, but the load could impact system piping, resulting in a spray leak. The load could also impact the AIVS sufficiently that hydrogen could build up inside the LDC and possibly ignite. Alternatively, the falling load could damage the HEPA filter and lead to an unfiltered release from the LDC. Ignition of hydrogen inside the LDC is described in Section 3.4.7. The unfiltered release accident is described in Section 3.4.14.

\subsubsection{Consequence Analysis}

A spray leak from slurry piping is analyzed in Section 3.4.1 and bounds the consequences of a sludge spill, which is analyzed in Section 3.4.2. It is unrealistic to assume that both a blocked discharge and a fire occur simultaneously; therefore, the consequences of an open discharge spray as presented in Table 3-12 are applicable. This scenario describes an unmitigated spray leak that occurs under maximum expected pressures at the slurry line connection to the LDC. It is expected that personnel would evacuate in the event of a fire and cease manipulating the sludge retrieval line end-effectors. This would limit the amount of sludge escaping from the pipe break to less than one canister, even if the sludge retrieval pump was left running longer than the 7.3 minutes assumed in Section 3.4.2. 


\section{SNF-10272 REV. 2}

\subsubsection{Comparison to Guidelines}

Dose consequences of the bounding unmitigated spray leak applicable to a fire scenario are reported in Table 3-13 and are within the "low" consequence bin.

\subsubsection{Summary of SSCs and TSR Controls}

The sludge transportation cask is assumed to withstand the impact of the falling crane, but no SSCs are proposed to prevent or mitigate this accident.

Implementation of the Fire Protection Program provides general fire protection to reduce the probability of the accident.

\subsubsection{Heavy Load Drop or Impact}

This section evaluates heavy load drops and impacts on the system or system components that could result in nuclear safety consequences. This includes events such as the overhead crane dropping the process shield plate or cask lid on the sludge transportation cask or impacting components such as IXMs, or sand filters with heavy loads. Heavy loads also include heavy sludge retrieval system components that could fall into the basin.

The transfer bay bridge crane is used to remove and reposition the sludge transportation cask lid and the process shield plate. An inadvertent lid drop could damage sludge retrieval system components. The bridge crane travel area covers the ion exchange column (IXCs), the ion exchange module (IXMs), and the western edges of the sand filter, the north load-out pit, and the south load-out pit. The bridge crane travel area does not cover the AIVS HEPA filter.

When not in use, the process shield plate is stored on a raised platform just south of the cask transporter. The platform is supported by the IXC shield wall.

\subsubsection{Scenario Development}

Heavy Load Drop on LDC. The cask lid weighs about 5,500 lb, and the process shield plate weighs about 14,500 lb. Following LDC filling, Sludge Retrieval System shutdown, and line flushing, a personnel error or equipment failure could cause the cask transport lid or process shield plate to drop onto the LDC. In the worst case, the process shield plate falls onto the LDC sideways. The diameter of the process shield plate is about $70 \mathrm{in}$. and the inside diameter of the cask is 61 in., so the edge of the process shield plate could extend 18 in. into the cask. The top of the LDC lift lug is just below the top of the cask, so the drop could damage the LDC by pushing the lift lug down. The LDC could possibly be breached at the ports, exposing the sludge to the atmosphere. Damage to slurry lines at this point should not be a problem because the Sludge Retrieval System is shut down and the lines are flushed before lifting the cask lid or process shield plate.

Heavy Load Drop on Sand Filter. Personnel error or equipment failure could cause the cask lid or process shield plate to hit the edge of the sand filter enclosure. Since the process shield plate is the heavier of the two, it is considered to bound a drop of the lid. 
The sand filter enclosure is made of 6-in.-thick concrete with a steel lid. If the drop height were $11 \mathrm{ft}$ (distance from the maximum crane height to the top of the enclosure), the impact velocity would be $27 \mathrm{ft} / \mathrm{s}$. An expression for penetration depth in concrete can be found in DOE-STD-3014-96, Accident Analysis for Aircraft Crash into Hazardous Facilities:

$$
t_{p}=0.765(f)^{-3 / 8}\left(\frac{W}{D}\right)^{1 / 2}(V)^{3 / 4}
$$

where

$$
\begin{aligned}
& t_{\mathrm{p}}=\text { penetration depth (in.) } \\
& \mathrm{f}=\text { compressive strength of concrete }\left(\mathrm{lb} / \mathrm{in}^{2}\right. \text { gauge) } \\
& \mathrm{W}=\text { missile weight }(\mathrm{lb}) \\
& \mathrm{D}=\text { missile nominal diameter }(\mathrm{in} .) \\
& \mathrm{V}=\text { missile impact velocity }(\mathrm{ft} / \mathrm{s}) .
\end{aligned}
$$

In this analysis, a typical strength of $3,000 \mathrm{lb} / \mathrm{in}^{2}$ is used for "f."

Missile impact absorption by the sand filter enclosure lid is conservatively neglected. Since this accident involves a flat cylindrical missile hitting edge-on rather than a longer missile hitting end-on, the missile's nominal diameter, "D," must be found from the impact area. The edge of the process shield plate is about $5 \mathrm{in}$. thick so the length of the impact area will increase as the process shield plate penetrates the concrete. A parametric study was performed to evaluate the sensitivity of the penetration depth, " $t_{p}$," to impact area. The penetration depth decreased with increasing impact area but finally stabilized at approximately $17 \mathrm{in.} \mathrm{(10} \mathrm{in.} \mathrm{for} \mathrm{the} \mathrm{cask} \mathrm{lid).} \mathrm{The}$ wall could crack and allow concrete fragments to fall and impact the sand filter vessel. The close proximity of the vessel to the shield wall prevents the fragments from attaining any appreciable momentum. The sand filter vessel is made of 0.25 -in. steel and is fabricated to the requirements of Section VIII of the ASME Boiler and Pressure Vessel Code (ASME 1998). A rupture of this vessel is unlikely; however, the outlet piping on the top of the vessel could be damaged and lead to a spray release of water containing dissolved ${ }^{137} \mathrm{Cs}$ and ${ }^{90} \mathrm{Sr}$. A spray leak from the sand filter is bounded by the analysis in Section 3.4.1 because radionuclide concentrations in sludge piping considerably exceed those expected in basin water.

Heavy Load Drop on Ion Exchange Module. Personnel error or equipment failure could cause the cask lid or process shield plate to drop onto the IXMs. Because the IXMs are encased in a monolithic block of concrete, they are expected to withstand the impact of the lid drop (see H-1-46279, Ion Exchange Module Assembly). The IXM water piping, however, is vulnerable to the lid drop. A spray leak in this event would be bounded by that analyzed in Section 3.4.1.

Heavy Load Drop on Ion Exchange Column. The IXCs are located within the reinforced concrete structure supporting the process shield plate support stand. Impact limiters are located on top of the IXC enclosure on either side of the safety-class PSP support stand. A load drop onto the IXC enclosure is not expected to result in any damage to the IXCs inside, and a release from the IXCs is not credible. 
Cask Lid or Process Shield Plate Drop into Basin. Personnel error or equipment failure could result in a drop of one of these heavy loads into the north or south load-out pit or basin proper. A heavy load drop that could cause separation at the joint with the $\mathrm{K}$ Basin wall or perforation of the floor is discussed in Section 3.4.2.1 of HNF-SD-WM-SAR-062. The same controls derived from this analysis would apply to crane movement of these components and restrict the load path away from the north and south load-out pits.

Collapse of the Process Shield Plate Stand. Collapse of the process shield plate stand could result in the process shield plate $(14,500 \mathrm{lb})$ falling, sliding, or rolling into the north load-out pit. A heavy load drop that could cause separation at the joint with the $\mathrm{K}$ Basin wall or perforation of the floor is discussed in Section 3.4.2.1 of HNF-SD-WM-SAR-062. This load exceeds the load limits in Table 3-10 of HNF-SD-WM-SAR-062. Therefore, the process shield plate stand performs safety-class functions and is designed and built to safety-class requirements.

Summary. Several potential drop events were analyzed in this section. The drop onto and release from the LDC is analyzed below. The potential spray release from the sludge retrieval line or overflow piping has been analyzed in Sections 3.4.1. Dropping the cask lid or process shield plate onto (or near enough to fall into) the north load-out pit is not acceptable according to the analyses presented in HNF-SD-WM-SAR-062, Section 3.4.2.1. The same applies to failure of the process shield plate stand.

\subsubsection{Source Term Analysis}

A spray leak from slurry piping is analyzed in Section 3.4.1. It is unrealistic to assume that both a blocked discharge and a heavy load drop occur simultaneously; therefore, the consequences presented in Table 3-13 are applicable. This scenario describes an unmitigated spray leak that occurs under maximum expected pressures at the slurry line connection to the LDC. It is expected that personnel would cease manipulating the sludge retrieval line end-effectors in the event of a load drop. This would limit the amount of sludge escaping from the pipe break to less than one canister, even if the sludge retrieval pump was left running longer than the 7.3 minutes assumed in Section 3.4.2.

It is conservatively assumed that dropping the cask lid or process shield plate onto the LDC could deform the top head of the LDC. The LDC is a right circular cylinder with elliptical heads, an inside diameter of $59 \mathrm{in}$., and a height of $108 \mathrm{in}$. The reduction in headspace volume caused by the drop can be approximated by a circular ellipsoid $59 \mathrm{in}$. in diameter and 18 in. deep. According to Avallone and Baumeister (1987), the volume displaced is given by the formula $(\pi \mathrm{D} 2 \mathrm{~h}) / 6$, which yields $32,800 \mathrm{in}^{3}\left(0.538 \mathrm{~m}^{3}\right)$. The shock of the impact is expected to create an aerosol inside the LDC headspace. NUREG/CR-2651 provides several comparative aerosol loadings for different natural and industrial conditions, which are shown in Table 3-35. 
Table 3-35. Comparative Aerosol Loadings.

\begin{tabular}{|l|l|}
\hline \multicolumn{1}{|c|}{ Aerosol } & \multicolumn{1}{c|}{ Concentration } \\
\hline Dust storm & 0.5 to $10 \mathrm{~g} / \mathrm{m}^{3}$ \\
\hline Natural clouds & $1 \mathrm{~g} / \mathrm{m}^{3}$ \\
\hline Explosion (few minutes after) & $100 \mathrm{mg} / \mathrm{m}^{3}$ \\
\hline Coal mine face, rain & 50 to $500 \mathrm{mg} / \mathrm{m}^{3}$ \\
\hline Fog & 5 to $50 \mathrm{mg} / \mathrm{m}^{3}$ \\
\hline Los Angeles smog & 0.5 to $50 \mathrm{mg} / \mathrm{m}^{3}$ \\
\hline Industrial atmosphere & 0.1 to $50 \mathrm{mg} / \mathrm{m}^{3}$ \\
\hline Nuisance dust & $10 \mathrm{mg} / \mathrm{m}^{3}$ \\
\hline Ambient atmosphere & 0.05 to $1.0 \mathrm{mg} / \mathrm{m}^{3}$ \\
\hline Air-conditioned building & $0.3 \mathrm{mg} / \mathrm{m}^{3}$ \\
\hline
\end{tabular}

The transient aerosol loading selected to represent this event is $1 \mathrm{~g} / \mathrm{m}^{3}$ as it appears reasonably conservative, and as will be shown below, it is not critical to the conclusions of the analysis. An RF of 0.25, discussed in Section 3.4.1.5, is used. The DR and LPF are 1.0. The source term is

$$
\mathrm{Q}=1 \mathrm{~g} / \mathrm{m}^{3} \times 0.538 \mathrm{~m}^{3} \times 0.25=0.13 \mathrm{~g} \text { of sludge } .
$$

\subsubsection{Consequence Analysis}

The release from a heavy load drop on the LDC is considered less than 1-hour release. The consequences are calculated using Equation 3-2 using the 0.13-g source term given above and the acute release $\chi / Q$ 's. The BR and UD for the sludge is taken from Section 3.3.2.5. The consequences are summarized in Table 3-36.

Table 3-36. Summary of Maximum Dose Consequences for Unmitigated Heavy Load Drop onto LDC.

\begin{tabular}{|c|c|c|c|}
\hline \multirow{2}{*}{$\begin{array}{l}\text { Receptor location } \\
\text { (distance, direction) }\end{array}$} & \multicolumn{2}{|c|}{ Unmitigated } & \multirow{2}{*}{$\begin{array}{c}\text { Evaluation guidelines } \\
\text { (rem) }\end{array}$} \\
\hline & $\chi / \mathbf{Q}^{\prime}$ & rem & \\
\hline $\begin{array}{l}\text { Onsite } \\
(100 \mathrm{~m}, \mathrm{E})\end{array}$ & $7.32 \mathrm{E}-02$ & $4.8 \mathrm{E}-02$ & 25 to 100 \\
\hline $\begin{array}{l}\text { Columbia River, near bank } \\
(520 \mathrm{~m}, \mathrm{~W})\end{array}$ & $3.55 \mathrm{E}-03$ & $3.8 \mathrm{E}-03$ & -- \\
\hline $\begin{array}{l}100 \text { Area Fire Station } \\
(3,750 \mathrm{~m}, \mathrm{ESE})\end{array}$ & $1.60 \mathrm{E}-04$ & $1.0 \mathrm{E}-04$ & -- \\
\hline $\begin{array}{l}\text { Hanford Site boundary } \\
(10,070 \mathrm{~m}, \mathrm{~W})\end{array}$ & $4.49 \mathrm{E}-05$ & $4.8 \mathrm{E}-05$ & 1 to 25 \\
\hline
\end{tabular}

Toxicological consequences are calculated using Equation 3-4. The release rate is $0.13 \mathrm{~g}$ divided by 15 minutes, or $1.44 \mathrm{E}-04 \mathrm{~g} / \mathrm{s}$. Since the source term is given in grams rather than $\mathrm{mL}$, the density is not needed, although the uranium fraction of the sludge is still included in the calculation. The results are shown in Table 3-37. 
Table 3-37. Downwind Uranium Concentration for Unmitigated Heavy Load Drop onto LDC.

\begin{tabular}{|l|c|c|c|}
\hline \multicolumn{1}{|c|}{$\begin{array}{c}\text { Receptor location } \\
\text { (distance, direction) }\end{array}$} & $\begin{array}{c}\chi / \mathbf{Q}^{\prime} \\
\left(\mathbf{s} / \mathbf{m}^{\mathbf{3}}\right)\end{array}$ & $\begin{array}{c}\text { Concentration } \\
\left(\mathbf{m g} / \mathbf{m}^{\mathbf{3}}\right)\end{array}$ & $\begin{array}{c}\text { Evaluation guidelines } \\
\left(\mathbf{m g} / \mathbf{m}^{\mathbf{3}}\right)\end{array}$ \\
\hline $\begin{array}{l}\text { Onsite } \\
(100 \mathrm{~m}, \mathrm{E})\end{array}$ & $7.32 \mathrm{E}-02$ & $8.9 \mathrm{E}-03$ & $\begin{array}{c}1 \text { to } 10 \\
\text { (EPRG-2 to EPRG-3) }\end{array}$ \\
\hline $\begin{array}{l}\text { Columbia River, near bank } \\
(520 \mathrm{~m}, \mathrm{~W})\end{array}$ & $3.55 \mathrm{E}-03$ & $4.3 \mathrm{E}-04$ & -- \\
\hline $\begin{array}{l}100 \text { Area Fire station } \\
(3,750 \mathrm{~m}, \text { ESE) }\end{array}$ & $1.60 \mathrm{E}-04$ & $1.9 \mathrm{E}-05$ & -- \\
\hline $\begin{array}{l}\text { Hanford Site boundary } \\
(10,070 \mathrm{~m}, \mathrm{~W})\end{array}$ & $4.49 \mathrm{E}-05$ & $5.4 \mathrm{E}-06$ & 0.6 to 1 \\
\hline
\end{tabular}

\subsubsection{Comparison to Guidelines}

The radiological and toxicological release consequences of dropping either the cask lid or process shield plate onto process piping, the LDC, or sand filter are not expected to challenge evaluation guidelines. Dose consequences of the bounding unmitigated spray leak applicable to a heavy load drop are reported in Table 3-12 and are within the "low" consequence bin. However, such a drop onto or near enough to roll into the north or south load-out pits cannot be tolerated according to the analyses presented in HNF-SD-WM-SAR-062, Section 3.4.2.1.

\subsubsection{Summary of Safety Structures, Systems, and Components and Technical Safety Requirement Controls}

The following SSC safety classifications are made.

- Process shield plate support stand - The process shield plate support stand holds the process shield plate about $3 \mathrm{ft}$ above the IXC platform. A failure of the support stand could result in the process shield plate falling, sliding, or rolling into the north load-out pit. The safety-class function of the process shield plate support stand is to provide structural support of the process shield plate under design basis loads in accordance with performance category 3 requirements.

- The sludge transportation cask provides a safety-significant function by withstanding the impact of the falling shield plate. This limits LDC damage to that assumed in Section 3.4.10.2.

A TSR AC provides specific heavy load controls for protection of the basins. Application to the cask lid, process shield plate, or spray shield components effectively restricts their load path from passing over the north or south load-out pits.

\subsubsection{Vehicle Impact}

HNF-SD-WM-SAR-062, Section 3.4.2.11, addresses the possibility of vehicles, such as trucks and forklifts, impacting equipment or support structures within the K Basins. The ultimate consequence is an accident that could damage the basin floor or walls of the north or south load- 
out pits or result in a heavy load drop as discussed in Section 3.4.10. Credit is taken in HNF-SD-WM-SAR-062 for bumpers, the ion-exchange columns, the sand filter enclosure, and the north and south load-out pit curbs as vehicle barriers. Analysis in HNF-SD-SNF-DA-012, Closure of Seismic Review Issues and Other Structural Safety Concerns for the $105 \mathrm{KE}$ and $105 \mathrm{KW}$ Spent Nuclear Fuel Basins, demonstrates that the sand filter can absorb the energy of a 100,000 -lb truck moving at $6.5 \mathrm{mi} / \mathrm{h}$ without causing it to impact column B-13. The fully loaded Sludge Transportation System, including tractor, weighs about 130,000 lb. Based on the kinetic energy of the accident analyzed, the sand filter can absorb the energy of a 130,000-lb vehicle moving at $5.7 \mathrm{mi} / \mathrm{h}$. Therefore, the sand filter shield box mass is adequate to perform its safetyclass function of stopping the Sludge Transportation System provided the AC for vehicle control is applied to the north transfer bay.

\subsubsection{High Radiation Dose}

\subsubsection{Scenario Development}

During SWS operations, operators could become exposed to high radiation fields through a number of scenarios. Two such scenarios are considered below:

- Approaching the unshielded LDC fill-line-connector when the line contains sludge

- Being exposed to a sludge-filled LDC with the process shield plate off.

\subsubsection{Source Term Analysis}

For an unshielded fill-line scenario, the source term is assumed to be a $1.0-\mathrm{m}$ section of pipe having a 2-in. inner diameter (for a volume of $2.03 \times 10^{-3} \mathrm{~m}^{3}$ ) that is filled with a mixture of canister sludge and water. Canister sludge is represented as $3.62 \times 10^{3} \mathrm{Ci} / \mathrm{m}^{3}$ of ${ }^{137} \mathrm{Cs}$ (see Table 3-3). Three different dilution factors are considered: undiluted (settled) sludge, design basis $30 \%$ sludge, and $1 \%$ sludge.

For the unshielded LDC scenario, the LDC is assumed to contain $2.0 \mathrm{~m}^{3}$ of a $60: 40$ mixture of floor and canister sludge for a total inventory of $6.0 \times 10^{3} \mathrm{Ci}$ (see Table 3-3). There is assumed to be $20 \mathrm{in}$. of water on top of the sludge and $0.5 \mathrm{in}$. of iron in the form of the LDC shell providing some shielding. The worker is assumed to be standing directly above the center of the LDC (approximately $57 \mathrm{in}$. above the top of the sludge).

\subsubsection{Consequence Analysis}

The dose to a worker resulting from the unshielded line and unshielded LDC scenarios were estimated using the MICROSHIELD (Version 3) computer code, as documented in Microshield Version 3 (Grove Engineering 1988). A simple, conservative model of the above scenarios was used to estimate the resulting doses. MICROSHIELD outputs are contained in Appendix E.

- For the filled-line scenario, the dose rate was evaluated at $0.1 \mathrm{~cm}, 34 \mathrm{~cm}$, and $1 \mathrm{~m}$ from the pipe surface. The source term was set to $1.0 \mathrm{Ci}$ and the results then normalized to the actual source term. The results of this analysis are shown in Table 3-38. 
- In the LDC scenario, the dose rate was evaluated at $1 \mathrm{~cm}, 1 \mathrm{~m}$, and $2 \mathrm{~m}$ above the top of the LDC. The source term was set to $1.0 \mathrm{Ci}$ and the results then normalized to the actual source term. The results of this analysis are shown in Table 3-39.

Table 3-38. Predicted Doses at Three Different Positions Relative to the Pipe and Using Three Different Dilution Factors.

\begin{tabular}{|c|c|c|c|}
\hline Sludge content & $\begin{array}{c}\text { Dose at contact } \\
(\mathbf{m R} / \mathbf{h})\end{array}$ & $\begin{array}{c}\text { Dose at 34 cm } \\
(\mathbf{m R} / \mathbf{h})\end{array}$ & $\begin{array}{c}\text { Dose at } \mathbf{~ m} \\
(\mathbf{m R} / \mathbf{h})\end{array}$ \\
\hline $100 \%$ & $3.2 \mathrm{E}+05$ & $1.3 \mathrm{E}+04$ & $2.2 \mathrm{E}+03$ \\
\hline $30 \%$ & $1.1 \mathrm{E}+05$ & $4.0 \mathrm{E}+03$ & $6.9 \mathrm{E}+02$ \\
\hline $1 \%$ & $3.6 \mathrm{E}+03$ & $1.3 \mathrm{E}+02$ & $2.3 \mathrm{E}+01$ \\
\hline
\end{tabular}

Table 3-39. Predicted Doses at Three Heights above the Top of the LDC.

\begin{tabular}{|c|c|c|}
\hline $\begin{array}{c}\text { Dose at contact } \\
(\mathbf{m R} / \mathbf{h})\end{array}$ & $\begin{array}{c}\text { Dose at } \mathbf{1} \mathbf{~ m} \\
(\mathbf{m R} / \mathbf{h})\end{array}$ & $\begin{array}{c}\text { Dose at } \mathbf{2} \mathbf{~ m} \\
(\mathbf{m R} / \mathbf{h})\end{array}$ \\
\hline $2.7 \mathrm{E}+03$ & $1.2 \mathrm{E}+03$ & $6.9 \mathrm{E}+02$ \\
\hline
\end{tabular}

\subsubsection{Comparison to Guidelines}

The 100-m evaluation guidelines do not apply to a facility worker; however, avoidance of serious worker injury or death is a requirement. Significant radiation fields are calculated above, but the use of shielding and minimizing worker exposure times in accordance with the ALARA Program will keep exposures to acceptable levels.

\subsubsection{Summary of Safety Structures, Systems, and Components and Technical Safety Requirement Controls}

No unique safety SSCs or controls are warranted. However the Radiation Protection Program controls are necessary to minimize worker radiation exposure.

\subsubsection{Uncontrolled Release of Argon}

While argon is not toxic, it is an asphyxiant so that leakage into any enclosed space presents an immediate and severe worker hazard. Dangers associated with inert gas systems, however, represent a common and well-understood industrial hazard.

Any accessible space containing any components of the active inert ventilation system (including any outside sheds covering argon cylinders) has the potential to contain an oxygen deficient atmosphere. Industrial standard precautions and procedures, including constant oxygen monitoring, will be applied in all such spaces which are normally occupied. In such spaces not normally occupied, standard procedures for worker entry into a potentially oxygen deficient space will be followed. Since argon is denser than air, it will tend to sink to the lowest points in the affected space. Particular care will therefore be taken when accessing even small spaces below floor level, such as sumps or pits, even when such spaces are open to the room above. 
All components of the active inert ventilation system will be periodically inspected and checked for leaks using argon detection equipment.

In the event of a large leak or rupture in the active inert ventilation system, all personnel should immediately evacuate the affected and adjacent spaces. Standard Hazardous Material Program procedures for entering oxygen deficient atmospheres should be used when re-entering these spaces. The pressure boundary of the AIVS is relied upon to reduce the frequency of the accident.

\subsubsection{Unfiltered Release from LDC or Cask}

During inerting of the cask and LDC, the vented argon passes through the AIVS HEPA filter before being exhausted outside the building. An unfiltered release could result from inadvertent bypassing of the HEPA filter, or from debris clogging VV-401 and allowing moisture to enter the HEPA filter. Malfunction or misoperation of the AIVS can result in system pressures sufficiently high to fail the HEPA filter and cause an unfiltered release.

\subsubsection{Scenario Development}

The HEPA filter is assumed to fail at the end of sludge loading, when the LDC contains the maximum amount of unsettled sludge, the water has been decanted, and the internal filters have not yet been backwashed. The backwashing is assumed to generate $100 \mathrm{mg} / \mathrm{m}^{3}$ of aerosol in the headspace, which is reasonably conservative (see Sections 3.4.7.2 and 3.4.10.2). Refilling the LDC with water expels the contaminate argon.

\subsubsection{Source Term Analysis}

The minimum LDC headspace volume is administratively controlled to $1.2 \mathrm{~m}^{3}$ to control hazards from hydrogen generation (see Section 3.4.3). For the purposes of this analysis, it is conservative to assume a headspace volume larger than the minimum. The volume is arbitrarily assumed to be $1.6 \mathrm{~m}^{3}$, and it is recognized that radiological and toxicological consequences depend linearly on this assumption. The maximum MAR in the assumed case is $0.16 \mathrm{~g}$. All of the suspended aerosol is assumed to be respirable. Since the entire headspace volume is expelled from the LDC, the LPF is taken to be 1 . The source term for this accident is $0.16 \mathrm{~g}$.

\subsubsection{Consequence Analysis}

The $\chi / Q^{\prime}$ for acute (less than 1 hour) releases is used. Although the filter damage may not be detected until much later, it is conservative to assume the shortest release time when selecting the $\chi / Q^{\prime}$. The UD for the sludge is taken from Section 3.3.2.5. The consequences are calculated using Equation 3-2 and are summarized in Table 3-40. 
Table 3-40. Summary of Maximum Dose Consequences for Unmitigated Unfiltered Release from LDC or Cask.

\begin{tabular}{|c|c|c|c|}
\hline \multirow{2}{*}{$\begin{array}{l}\text { Receptor location } \\
\text { (distance, direction) }\end{array}$} & \multicolumn{2}{|c|}{ Unmitigated } & \multirow{2}{*}{$\begin{array}{l}\text { Evaluation guidelines } \\
\text { (rem) }\end{array}$} \\
\hline & $\chi / \mathbf{Q}^{\prime}$ & rem & \\
\hline $\begin{array}{l}\text { Onsite } \\
(100 \mathrm{~m}, \mathrm{E})\end{array}$ & $7.32 \mathrm{E}-02$ & $5.9 \mathrm{E}-02$ & 25 to 100 \\
\hline $\begin{array}{l}\text { Columbia River, near bank } \\
(520 \mathrm{~m}, \mathrm{~W})\end{array}$ & $3.55 \mathrm{E}-03$ & 4.7E-03 & -- \\
\hline $\begin{array}{l}100 \text { Area Fire Station } \\
(3,750 \mathrm{~m}, \mathrm{ESE})\end{array}$ & $1.60 \mathrm{E}-04$ & $1.3 \mathrm{E}-04$ & -- \\
\hline $\begin{array}{l}\text { Hanford Site boundary } \\
(10,070 \mathrm{~m}, \mathrm{~W})\end{array}$ & $4.49 \mathrm{E}-05$ & $5.9 \mathrm{E}-05$ & 1 to 25 \\
\hline
\end{tabular}

The toxicological consequences are found from Equation 3-4. The release rate is found by dividing the $0.16-\mathrm{g}$ source term by 15 minutes, or $1.78 \mathrm{E}-04 \mathrm{~g} / \mathrm{s}$. Since the source term is given in grams rather than $\mathrm{mL}$, the density is not needed, although the uranium fraction of the sludge is still included in the calculation. The results are shown in Table 3-41.

Table 3-41. Downwind Uranium Concentration for Unmitigated Unfiltered Release from LDC or Cask.

\begin{tabular}{|l|c|c|c|}
\hline \multicolumn{1}{|c|}{$\begin{array}{c}\text { Receptor location } \\
\text { (distance, direction) }\end{array}$} & $\begin{array}{c}\boldsymbol{\alpha} / \mathbf{Q}^{\prime} \\
\left(\mathbf{s} / \mathbf{m}^{\mathbf{3}}\right)\end{array}$ & $\begin{array}{c}\text { Concentration } \\
\left(\mathbf{m g} / \mathbf{m}^{\mathbf{3}}\right)\end{array}$ & $\begin{array}{c}\text { Evaluation guidelines } \\
\left(\mathbf{m g} / \mathbf{m}^{\mathbf{3}}\right)\end{array}$ \\
\hline $\begin{array}{l}\text { Onsite } \\
(100 \mathrm{~m}, \mathrm{E})\end{array}$ & $7.32 \mathrm{E}-02$ & $1.1 \mathrm{E}-02$ & 1 to 10 \\
\hline $\begin{array}{l}\text { Columbia River, near bank } \\
(520 \mathrm{~m}, \mathrm{~W})\end{array}$ & $3.55 \mathrm{E}-03$ & $5.3 \mathrm{E}-04$ & -- \\
\hline $\begin{array}{l}100 \text { Area Fire station } \\
(3,750 \mathrm{~m}, \mathrm{ESE})\end{array}$ & $1.60 \mathrm{E}-04$ & $2.4 \mathrm{E}-05$ & -- \\
\hline $\begin{array}{l}\text { Hanford Site boundary } \\
(10,070 \mathrm{~m}, \mathrm{~W})\end{array}$ & $4.49 \mathrm{E}-05$ & $6.7 \mathrm{E}-06$ & 0.6 to 1 \\
\hline
\end{tabular}

\subsubsection{Comparison to Guidelines}

The unmitigated unfiltered release consequences are within the "low" consequence bin. Any reasonable alternative assumption regarding LDC headspace volume would not challenge "moderate" consequence guidelines.

\subsubsection{Summary of SSC and TSR Controls}

No safety-significant SSC or TSR controls are required for the unmitigated unfiltered release. 


\subsubsection{Loss of Electrical Power}

Electrical power to the Hanford Site is supplied by the Bonneville Power Authority. K Basins has no backup electrical generator, but does have battery-powered emergency lights for worker evacuation. The $\mathrm{K}$ Basins bridge crane stops in place on loss of power.

In the event of a loss of power to $\mathrm{K}$ Basins, sludge retrieval operations will be halted. The possibility of radiological or toxicological hazards depends on the timing of the outage. If electrical power is lost prior sludge loading, for example, no hazard will exist.

If power is lost while loading sludge into the LDC, the sludge pumps will stop. The LDC will then decant by gravity and fill with argon from the AIVS. The only electrically-operated AIVS components are SOV-401 (normally open and fail open) and the oxygen analyzer (which is not used during sludge loading). Air cannot enter the LDC in this configuration, so there is no danger of a combustible gas mixture accumulating inside the LDC.

If power is lost while disconnecting the hoses, the LDC ports will be open to the atmosphere, but the LDC is filled with argon. Since argon is heavier than air, there will be little air ingress to the LDC with or without the vent filters installed. Any hydrogen generated will escape to the transfer bay and not accumulate in the LDC headspace.

If power is lost after the cask lid is installed, but prior to inerting the cask, the cask can be inerted without electrical power.

If power goes out with the cask inerted and isolated, it can be transported to T Plant.

\subsubsection{Natural Phenomena Hazards}

Natural phenomena hazards identified in HNF-SD-WM-SAR-062 are:

- Floods. The design basis flood level identified by DOE-RL-HPS-SDC-4.1, Standard Architectural-Civil Design Criteria: Design Loads for Facilities, for safety class facilities at $100 \mathrm{~K}$ is 432 feet, and there are no flood requirements for safety-significant SSCs. K Basins is located at an elevation of 465 feet.

- Seismology. The design basis earthquake (DBE) for Hanford nonreactor safety-class structures is a seismic event producing $0.12 \mathrm{~g}$ horizontal ground acceleration simultaneously with a vertical acceleration of $0.08 \mathrm{~g}$. Both the $\mathrm{K}$ Basins transfer bay structure and the argon storage annex, were designed to withstand the DBE in accordance with DOE-RL-HPS-SDC-4.1. The bridge crane and process shield plate support stand are also designed to withstand the DBE. The AIVS piping is designed and installed to ASME B31.1, but is considered a general service item. A DBE could result in inoperability of the system and result in an uncontrolled release of argon, as described in Section 3.4.13. This condition could also result in the buildup and possible ignition of hydrogen, as described in Section 3.4.7. 
- Wind. Wind load design requirement are established in DOE-RL-HPS-SDC-4.1. The argon storage building was designed to withstand this wind loading. The $\mathrm{K}$ Basins structure was designed to withstand a bomb blast.

- Ashfall. Both $\mathrm{K}$ Basins and the argon storage building were designed to withstand the design basis ashfall loading in accordance with DOE-RL-HPS-SDC-4.1.

- Thunderstorms. The principal hazard associated with thunderstorms is lightning-induced wildfires.

No specific TSR controls are credited; however, the Emergency Preparedness Program would control actions during natural phenomena hazards.

\subsubsection{External Hazards}

External man-made threats identified in HNF-SD-WM-SAR-062 are aircraft activity and transportation accidents (e.g., toxic chemical release) on State Route 24 and State Route 240. The probability per year of an aircraft impacting the facility has been calculated to be $1.5 \mathrm{E}-08$. This frequency is "beyond extremely unlikely" and this hazard is not considered in HNF-SDWM-SAR-062. Highway accidents are judged to present a negligible risk to $\mathrm{K}$ Basins because of the distance between the facility and the highway. Traffic on the Columbia River is primarily small fishing boats. The Hanford Site railroad has been deactivated, and railroad track inside the $100 \mathrm{~K}$ fence has been removed. The Emergency Preparedness Program would control actions during an external hazard event.

\subsubsection{Beyond Design Basis Accidents}

The Beyond Design Basis Accidents identified in HNF-SD-WM-SAR-062 are:

- Underwater Fuel Burn. This accident occurs entirely within the fuel canisters in the basin and does not involve the SWS. For this reason, it is not considered.

- Beyond Design Basis Earthquake. Since a DBE is already postulated to result in inoperability of the AIVS, a Beyond Design Basis Earthquake (see Section 3.4.17) would have no additional effect and is not considered.

- FTS Fire. This accident involves the Shielded Transfer Cask and does not involve the SWS. For this reason, it is not considered.

- FTS Heavy Load Drop. This accident involves load drops into the basin and does not affect the SWS. For this reason, it is not considered. Load drops that do affect the SWS are analyzed in Section 3.4.10.

\subsection{ACCIDENT FREQUENCY ASSESSMENT}

Accident frequencies are calculated in Appendix 3A of HNF-SD-WM-SAR-062. 
SNF-10272 REV. 2

\subsection{REFERENCES}

10 CFR 71, 1995, "Packaging and Transportation of Radioactive Material," Code of Federal Regulations, as amended.

30855-05, 1999, Compilation and Integration of K Basin Particle Size Analysis Data, Pacific Northwest National Laboratory, Richland, Washington.

AD-A015 822, 1975, Design Criteria for Flame Control Devices for Cargo Venting Systems, Arthur D. Little, Incorporated, Boston, Massachusetts.

AEC, 1968, Meteorology and Atomic Energy, U.S. Atomic Energy Commission, Washington, D.C.

AIChE, 1992, Guidelines for Hazard Evaluation Procedures, Second Edition, American Institute of Chemical Engineers, New York, New York.

ANSI N46.1-1980, 1980, Guidance for Defining Safety-Related Features of Nuclear Fuel Cycle Facilities, American National Standards Institute, New York, New York.

ASME, 1998, Boiler and Pressure Vessel Code, 2000 Addenda, American Society of Mechanical Engineers, New York, New York.

Avallone, E., and T. Baumeister, Editors, 1987, Marks' Standard Handbook for Mechanical Engineers, Ninth Edition, McGraw-Hill Book Company, New York, New York.

Bulletin 503, 1952, Limits of Flammability of Gases and Vapors, U.S. Bureau of Mines, Washington, D.C.

Crowl, D. A., and J. F. Louvar, 1990, Chemical Process Safety: Fundamentals with Applications, Prentice Hall, Englewood Cliffs, New Jersey.

DOE-HDBK-3010-94, 1994, Airborne Release Fractions/Rates and Respirable Fractions for Nonreactor Nuclear Facilities, U.S. Department of Energy, Washington, D.C.

DOE/RL-2002-50, 2003, RADIDOSE for Hanford, Revision 1, U.S. Department of Energy, Richland, Washington.

DOE-RL-HPS-SDC-4.1, 1989, Standard Architectural-Civil Design Criteria: Design Loads for Facilities, Revision 11, U.S. Department of Energy, Richland, Washington.

DOE-STD-1027-92, 1997, Hazard Categorization and Accident Analysis Techniques for Compliance with DOE Order 5480.23, Nuclear Safety Analysis Reports, Change Notice 1, U.S. Department of Energy, Washington, D.C.

DOE-STD-3009-94, 1994, Preparation Guide for U.S. Department of Energy Nonreactor Nuclear Facility Safety Analysis Reports, Change 2, U.S. Department of Energy, Washington, D.C. 
DOE-STD-3014-96, 1996, Accident Analysis for Aircraft Crash into Hazardous Facilities, U.S. Department of Energy, Washington, D.C.

ER-3C-0126-02, 2002, K-East Basin Sludge Transport System - Large Diameter Container: Proof of Principle Test Report, Rev. 1, AvanTech, Inc., Columbia, South Carolina.

ER-3C-0126-04, 2002, K East Basin Sludge Transport System - Large Diameter Container: Proof of Principle Test \#2 Report, Rev. 0, AvanTech, Inc., Columbia, South Carolina.

ER-3C-0126-07, 2002, K-East Basin Sludge Transport System - Large Diameter Container; Factory Acceptance Test Report, AvanTech, Inc., Columbia, South Carolina.

FAI/96-29, 1996, Detonation Potential for Selected Hanford Tank Farm Applications, Fauske and Associates, Burr Ridge, Illinois.

FM 99-5, 2000, Validation of Detailed Reaction Mechanisms for Detonation Simulation, Explosion Dynamics Laboratory, California Institute of Technology, Pasadena, California.

Grove Engineering, 1988, Microshield Version 3, Grove Engineering, Inc., Rockville, Maryland.

H-1-46279, 2001, Ion Exchange Module Assembly, Rev. 6, Fluor Hanford, Inc., Richland, Washington.

Hinds, W. C., 1982, Aerosol Technology - Properties, Behavior, and Measurement of Airborne Particles, John Wiley \& Sons, New York, New York.

HNF-1777, 2000, $K$ West Basin Integrated Water Treatment System Annular Filter vessel Accident Calculation and Derivation of Leak Path Factor, Rev. 5, Fluor Hanford Inc., Richland, Washington.

HNF-6964, 2002, Safety Analysis for Spent Nuclear Fuel Sludge Storage at T Plant, Rev. 0, DRAFT, Fluor Hanford, Inc., Richland, Washington.

HNF-8513, 2002, CSER 01-002: Criticality Safety Evaluation Report for Loading, Transport, and Storage of K Basin Sludge Containers, Rev. 1, Fluor Hanford Inc., Richland, Washington.

HNF-10280, 2002, FAI/02-08 - Sludge Settling and Segregation During Loading, Rev. 0, Fluor Hanford, Inc., Richland, Washington.

HNF-12563, 2002, Accident and Thermal Analysis for Handling and Storing K-E Basin Sludge at T Plant, Rev. 0, Fluor Hanford, Inc., Richland, Washington.

HNF-PRO-700, 2003, Safety Basis Development, Rev. 7, Fluor Hanford, Inc., Richland, Washington. 
HNF-SD-CP-SAR-021, 2002, Plutonium Finishing Plant Final Safety Analysis Report, Rev. 3, Fluor Hanford, Inc., Richland, Washington.

HNF-SD-SNF-DA-012, 1997, Closure of Seismic Review Issues and Other Structural Safety Concerns for the $105 \mathrm{KE}$ and $105 \mathrm{KW}$ Spent Nuclear Fuel Basins, Rev. 0, Fluor Daniel Hanford, Inc., Richland, Washington.

HNF-SD-SNF-FHA-001, 2002, Fire Hazards Analysis for the K Basins Facilities at $100 \mathrm{~K}$ Area, Rev. 1B, Fluor Hanford Inc., Richland, Washington.

HNF-SD-SNF-TI-009, 2001, 105-K Basin Material Design Basis Feed Description for Spent Nuclear Fuel Project Facilities, Volume 2, Sludge, Rev. 4, Fluor Hanford, Inc., Richland, Washington.

HNF-SD-SNF-TI-015, Volume 1, 2001, Spent Nuclear Fuel Project Technical Databook, Rev. 7, Fluor Hanford, Inc., Richland, Washington.

HNF-SD-SNF-TI-015, Volume 2, 2001, Spent Nuclear Fuel Project Technical Databook, Volume 2, Sludge, Rev. 9, Fluor Hanford, Inc., Richland, Washington.

HNF-SD-SNF-TI-059, 1999, A Discussion on the Methodology for Calculating Radiological and Toxicological Consequences for the Spent Nuclear Fuel Project at the Hanford Site, Rev. 2, Fluor Daniel Hanford, Inc., Richland, Washington.

HNF-SD-TP-SARP-017, 2002, Safety Analysis Report for Packaging (Onsite) Multi-canister Overpack Cask, Rev. 3-B, Fluor Hanford, Inc., Richland, Washington.

HNF-SD-SNF-TSR-001, 2003, Rev. 4, Technical Safety Requirements - $100 \mathrm{KE}$ and $100 \mathrm{KW}$ Fuel Storage Basins, Fluor Hanford, Inc., Richland, Washington.

HNF-SD-WM-SAR-062, 2003, $K$ Basins Safety Analysis Report, Rev. 7, Fluor Hanford, Inc., Richland, Washington.

ICRP-66, 1994, Human Respiratory Tract Model for Radiological Protection, International Commission on Radiological Protection, Elsevier Science, Tarrytown, New York.

ICRP-68, 1994, Dose Coefficients for Intakes of Radionuclides by Workers - Replacement of ICRP Publication 61, International Commission on Radiation Protection, , Elsevier Science, Tarrytown, New York.

ICRP-72, 1996, Age-dependent Doses to Members of the Public from Intake of Radionuclides: Part 5 Compilation of Ingestion and Inhalation Dose Coefficients, International Commission on Radiation Protection, , Elsevier Science, Tarrytown, New York.

Lefebvre, A. H., 1989, Atomization and Sprays, Hemisphere Publishing Corp., New York, New York. 


\section{SNF-10272 REV. 2}

Moen, I.O., 1993, Transition to detonation in fuel-air explosive clouds, Journal of Hazardous Materials, Volume 33 pages 159-192, Elseiver Science Publishers, Amsterdam, the Netherlands.

NEC, 2002, National Electrical Code, National Fire Protection Association, Quincy, Massachusetts.

NRC Regulatory Guide 1.145, 1982, Atmospheric Dispersion Models for Potential Accident Consequence Assessments at Nuclear Power Plants, U.S. Nuclear Regulatory Commission, Washington, D.C.

NUREG-1140, 1987, A Regulatory Analysis on Emergency Preparedness for Fuel Cycle and Other Radioactive Material Licensees, U.S. Nuclear Regulatory Commission, Washington, D.C.

NUREG/CR-2651, 1982, Accident Generated Particulate Materials and Their Characteristics A Review of Background Information, Pacific Northwest Laboratory, Richland, Washington.

NUREG/CR-4593, 1986, Initial Concepts on Energetic and Mass Releases During Nonnuclear Explosive Events in Fuel Cycle Facilities, Pacific Northwest Laboratory, Richland, Washington.

NUREG/CR-4803, 1987, The Possibility of Local Detonation During Degraded - Core Accidents at the Bellefonte Nuclear Power Plant, Sandia National Laboratory, Albuquerque, New Mexico.

NUREG/CR-5275, 1989, FLAME Facility, Sandia National Laboratory, Albuquerque, New Mexico.

PNNL-13854, 2002, Settling Test Using Simulant to Emulate Uranium Metal Distribution in $K$ Basin Sludge, Pacific Northwest National Laboratory, Richland, Washington.

RPP-11482, 2003, Atmospheric Dispersion Coefficients and Radiological and Toxicological Exposure Methodology for Use in Tank Farms, Rev 0, CH2M Hill Hanford Group, Inc., Richland, Washington.

SNF-7765, 2001, Supporting Basis for Spent Nuclear Fuel Project Sludge Technical Databook, Rev. 0, Fluor Hanford, Inc., Richland, Washington.

SNF-8166, 2003, Functional Design Criteria, K East Basin Sludge and Water System, Subproject A-16, Rev. 2, Fluor Hanford, Inc., Richland, Washington.

SNF-8626, 2001, K Basin Sludge and Water System Preliminary Hazard Analysis, Rev. 0, Fluor Hanford, Richland, Washington.

SNF-8677, 2002, Fire Hazard Analysis for the K Basin Sludge and Water System Project, A-16, Rev. 0, DRAFT, Fluor Hanford, Inc., Richland, Washington. 


\section{SNF-10272 REV. 2}

SNF-9955, 2002, Safety-Basis Thermal Analysis for KE Basin Sludge Transport and Storage, Rev. 0, Fluor Hanford, Inc., Richland, Washington.

SNF-10020, 2003, Hazard Evaluation for KE Sludge and Water System-Project A.16, Rev. 2, Fluor Hanford, Inc., Richland, Washington.

SNF-10208, 2002, Sludge and Water System Preliminary Documented Safety Analysis, Rev. 0, Fluor Hanford, Inc., Richland, Washington.

SNF-10293, 2002, Evaluation of KE Basin Sludge Radioisotopics and Volumes in Support of the Sludge and Water System Safety Analysis, Rev. 0, Fluor Hanford, Inc., Richland, Washington.

SNF-10415, 2002, Design-Basis Thermal and Gas Generation Analysis for KE Basin Sludge in Large Diameter Containers, Rev. 0, Fluor Hanford, Inc., Richland, Washington.

SNF-10823, 2003, Package Safety Analysis Assessment for Sludge Transportation System, Rev. 1, Fluor Hanford, Inc., Richland, Washington.

SNF-18133, 2003, Gas Behavior in Large Diameter Containers (LDCs) During and Following Loading with $105 \mathrm{~K}$ East Sludge, Rev. 0, Fluor Hanford Inc., Richland, Washington.

SNF-18135, 2003, Design Calculations for Gas Flow and Diffusion in Large Diameter Container and Cask, Rev. 0, Fluor Hanford Inc., Richland, Washington.

Steindler, M. J., and W. B. Seefeldt, 1980, A Method for Estimating the Challenge to an Air Cleaning System Resulting from an Accidental Explosive Event, Proceeding of the $16^{\text {th }}$ DOE Air Cleaning Conference, M. W. First, Editor, Harvard Air Cleaning Laboratory, Boston, Massachusetts.

T-CLC-H-00662, 2003, Evaluation of the High Level Waste Transfer Piping System for Potential Explosion Loads (U), Westinghouse Savannah River Company, Aiken, South Carolina.

WHC-SD-GN-SWD-20007, 1994, A Model for Predicting Respirable Release from Pressurized Leaks, Rev. 0, Westinghouse Hanford Company, Richland, Washington.

WHC-SD-GN-SWD-30002, 1995, GXQ 4.0 Program Users' Guide, Rev. 1, Westinghouse Hanford Company, Richland, Washington.

WHC-SD-GN-SWD-30003, 1995, GXQ 4.0 Program Verification and Validation, Rev. 1, Westinghouse Hanford Company, Richland, Washington.

WSMS-SAE-02-0001, 2002, EPRGs and TEELs for Chemicals of Concern, Rev. 18, Westinghouse Safety Management Solutions, Aiken, South Carolina. 


\section{SNF-10272 REV. 2}

Zalash, R.G., 1993, Hydrogen Combustion in Reactor Containment Buildings, Vol. 2, A Review of Experimental Data and State-of-the-Art Computer Codes, Final Report prepared for Industry Degraded Core Research (IDCOR) Program, Task 12.3. 


\section{APPENDIX A - SPRAY CODE OUTPUT FOR SRS SPRAY RELEASE}

Appendix A contains the SPRAY code output used to calculate leak rates and airborne release fractions contained in Table 3-8. Four SPRAY code output files are provided for the cases shown in Table 3-8. Details of the spray scenario are provided in Section 3.4.1. 
SNF-10272 REV. 2

This page is intentionally left blank. 
SNF-10272 REV. 2

SPRAY Version 3.0

May 3, 1994

Spray Leak code

Produced by Radiological \& Toxicological Analysis

Westinghouse Hanford Company

Run Date $=06 / 25 / 02 /$

Run $\mathrm{Time}=12: 36: 06.53$

INPUT ECHO :

C swS Unmitigated Spray Leak - Optimal

C SPRAY Version 3 Input Deck

c mode iflow iopt

$$
20 \quad T
$$

c

C MODEL OPTIONS:

$c$ mode $=1$ then orifice leak with friction assumed

c 2 then slit leak with friction assumed

c iflow= 0 Reynold's number determines friction relation (i.e. laminar or turb.

c $\quad 1$ friction based on Iaminar relation

C $=2$ friction based on turbulent relation 
$\mathrm{c}$ iopt $=\mathrm{T}$ then optimal diameter search performed

C $=F$ then no optimal search

c

C PARAMETER INPUT:

$c$

c Initial slit slit or

C Width or slit orifice

c Orifice Dia. Length Depth

c (in) (in) (in)

$c$
$1.00000 \mathrm{E}-02$
$2.00000 E+00$
1. 54000E-01

$c$

$c$

Absolute

c

Surface

c

Roughness

Contraction

velocity

c

(in)

Coefficient

Coefficient

c Pressure

0.00006 tube

0.61 and

0.98 for sharp edge orifice

c Differential

0.0018 steel 1.00 and

0.98 for rounded orifice

c (psi)

0.0102 iron

1.00 and

0.82 for square edge orifice

c

$$
7.50000 E+01
$$

$1.80000 \mathrm{E}-03$

1. $00000 \mathrm{E}+00$

8.20000E-01

c

C Fluid

Dynamic

Respirable

RR Fitting

c Specific

viscosity

Diameter

Constant

c Gravity

(centi-poise) (æm)

(q)

c

1. $00000 \mathrm{E}+00$

1. $00000 \mathrm{E}+00$

$2.00000 \mathrm{E}+01$

$2.40000 \mathrm{E}+00$

MESSAGES : 
SNF-10272 REV. 2

Slit Model

Code search for optimal equivalent diameter.

OUTPUT :

Liquid Velocity $=5.14 \mathrm{E}+01 \mathrm{ft} / \mathrm{s} \quad 1.57 \mathrm{E}+01 \mathrm{~m} / \mathrm{s}$

Reynolds Number $=3.57 \mathrm{E}+03$ Critical Flow

Sauter Mean Diameter $=8.59 \mathrm{E}+01 \mathrm{~m}$

Optimum Slit width $=4.50 \mathrm{E}-03$ in $\quad 1.14 \mathrm{E}-04 \mathrm{~m}$

Respirable Fraction $=1.09 \mathrm{E}-02$

Total Leak Rate $=1.44 \mathrm{E}+00 \mathrm{gpm} \quad 9.09 \mathrm{E}-05 \mathrm{m3} / \mathrm{s} \quad 9.09 \mathrm{E}+01 \mathrm{~g} / \mathrm{s}$

Respirable Leak Rate $=1.57 \mathrm{E}-02 \mathrm{gpm} \quad 9.90 \mathrm{E}-07 \mathrm{~m} 3 / \mathrm{s} \quad 9.90 \mathrm{E}-01 \mathrm{~g} / \mathrm{s}$ 
SNF-10272 REV. 2

SPRAY Version 3.0

May 3, 1994

Spray Leak Code

produced by Radiological \& Toxicological Analysis

Westinghouse Hanford Company

Run Date $=06 / 25 / 02 /$

Run Time $=12: 36: 37.56$

INPUT ECHO:

C SWS Unmitigated Spray Leak - $0.3 \mathrm{~mm}$

C SPRAY Version 3 Input Deck

c mode iflow iopt

$2 \quad 0 \quad E$

$\mathrm{C}$

C MODEL OPTIONS :

$\mathrm{c}$ mode $=1$ then orifice leak with friction assumed

c 2 then slit leak with friction assumed

c iflow $=0$ Reynold's number determines friction relation (i.e. laminar or turb.

C = 1 friction based on laminar relation

C $=2$ friction based on turbulent relation 
c iopt $=T$ then optimal diameter search performed

c $=F$ then no optimal search

c

C PARAMETER INPUT:

C

c Initial slit slit or

c Width or slit orifice

c Orifice Dia. Length Depth

c (in) (in) (in)

c

$1.18000 \mathrm{E}-02$

$2.00000 E+00$

$1.54000 \mathrm{E}-01$

C

$\mathrm{C}$

Absolute

C

Surface

c

Roughness

Contraction

Velocity

C

Coefficient

coefficient

C Pressure

0.00006 tube

0.61 and

0.98 for sharp edge orifice

c Differential

0.0018 steel

1.00 and

0.98 for rounded orifice

c (psi)

0.0102 iron

1.00 and

0.82 for square edge orifice

c

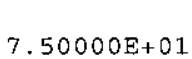

$1.80000 \mathrm{E}-03$

1. $00000 \mathrm{E}+00$

8. 20000E-01

c

c Fluid

Dynamic

Respirable

RR Fitting

c Specific

viscosity

Diameter

constant

c Gravity

(centi-poise)

(æm)

(q)

c

$1.00000 E+00$

$1.00000 \mathrm{E}+00$

$2.00000 E+01$

$2.40000 E+00$

MESSAGES : 
SNF-10272 REV. 2

slit Model

User specified orifice diameter or slit width.

OUTPUT :

Liquid Velocity $=7.33 \mathrm{E}+01 \mathrm{ft} / \mathrm{s} \quad 2.23 \mathrm{E}+01 \mathrm{~m} / \mathrm{s}$

Reynolds Number $=1.33 \mathrm{E}+04$ Turbulent Flow

Sauter Mean Diameter $=1.91 \mathrm{E}+02 \mathrm{~m}$

Respirable Fraction $=1.61 \mathrm{E}-03$

Total Leak Rate $=5.39 \mathrm{E}+00 \mathrm{gpm}$

$3.40 \mathrm{E}-04 \mathrm{~m} 3 / \mathrm{s}$

$3.40 \mathrm{E}+02 \mathrm{~g} / \mathrm{s}$

Respirable Leak Rate $=8.69 \mathrm{E}-03 \mathrm{gpm}$

$5.48 \mathrm{E}-07 \mathrm{~m} 3 / \mathrm{s}$

$5.48 \mathrm{E}-01 \mathrm{~g} / \mathrm{s}$ 
SNF-10272 REV. 2

SPRAY Version 3.0

May 3, 1994

Spray Leak code

Produced by Radiological \& Toxicological Analysis

Westinghouse Hanford Company

Run Date $=06 / 25 / 02 /$

Run $\mathrm{T}$ ime $=12: 36: 42.18$

INPUT ECHO:

C swS Unmitigated Spray Leak - $0.5 \mathrm{~mm}$

c SPRAY Version 3 Input Deck

c mode iflow iopt

$$
\text { 2. } 0 \text { F }
$$

C

C MODEL OPTIONS:

$c$ mode $=1$ then orifice leak with friction assumed

c 2 then slit leak with friction assumed

c iflow $=0$ Reynold's number determines friction relation (i.e. laminar or turb.

c = 1 friction based on laminar relation

c $\quad=2$ friction based on turbulent relation 
$\mathrm{C}$ iopt $=\mathrm{T}$ then optimal diameter search performed

c $=\mathrm{F}$ then no optimal search

c

C PARAMETER INPUT:

C

c Initial slit

slit or

C Width or

slit

Orifice

c Orifice Dia.

Length

Depth

c (in)

(in)

(in)

c

$1.97000 \mathrm{E}-02$

$2.00000 E+00$

$1.54000 \mathrm{E}-01$

C

Absolute

C Surface Roughness

Contraction

velocity

c

(in)

Coefficient

Coefficient

C Pressure

0.00006 tube

0.61 and

0.98 for sharp edge orifice

c Differential

0.0018 steel

1.00

and

0.98 for rounded orifice

C (psi)

0.0102 iron

1.00 and

0.82 for square edge orifice

$\mathrm{c}$

$7.50000 E+01$

$1.80000 \mathrm{E}-03$

$1.00000 \mathrm{E}+00$

8.20000E-01

c

c Fluid

Dynamic

Respirable

RR Fitting

c Specific

Viscosity

Diameter

Constant

c Gravity

(centi-poise) (æm)

(q)

c

$1.00000 \mathrm{E}+00$

$1.00000 \mathrm{E}+00$

$2.00000 E+01$

$2.40000 E+00$

MESSAGES : 
SNF-10272 REV. 2

Slit Model

User specified orifice diameter or slit width.

OUTPUT :

Liquid Velocity $=7.95 \mathrm{E}+01 \mathrm{ft} / \mathrm{s} \quad 2.42 \mathrm{E}+01 \mathrm{~m} / \mathrm{s}$

Reynolds Number $=2.40 \mathrm{E}+04$ Turbulent Flow

Sauter Mean Diameter $=3.24 \mathrm{E}+02 \mathrm{~mm}$

Respirable Fraction $=4.54 \mathrm{E}-04$

Total Leak Rate $=9.76 \mathrm{E}+00 \mathrm{gpm}$

$6.16 \mathrm{E}-04 \mathrm{~m} 3 / \mathrm{s}$

$6.16 \mathrm{E}+02 \mathrm{~g} / \mathrm{s}$

Respirable Leak Rate $=4.43 \mathrm{E}-03 \mathrm{gpm}$

$2.79 \mathrm{E}-07 \mathrm{~m} 3 / \mathrm{s}$

$2.79 \mathrm{E}-01 \mathrm{~g} / \mathrm{s}$ 
SNF-10272 REV. 2

SPRAY Version 3.0

May 3, 1994

Spray Leak Code

Produced by Radiological \& Toxicological Analysis

Westinghouse Hanford Company

Run Date $=09 / 23 / 03 /$

Run Time $=07: 29: 34.51$

INPUT ECHO:

C SWS Unmitigated Spray Leak - $0.3 \mathrm{~mm} @ 45 \mathrm{psi}$

C SPRAY Version 3 Imput Deck

c mode iflow iopt

$2 \quad 0 \quad F$

$\mathrm{C}$

C MODEL OPTIONS:

$c$ mode $=1$ then orifice leak with friction assumed

C 2 then slit leak with friction assumed

c iflow $=0$ Reynold's number determines friction relation (i.e. laminar or turb.

c = 1 friction based on laminar relation

c $=2$ friction based on turbulent relation

$c$ iopt $=T$ then optimal diameter search performed 


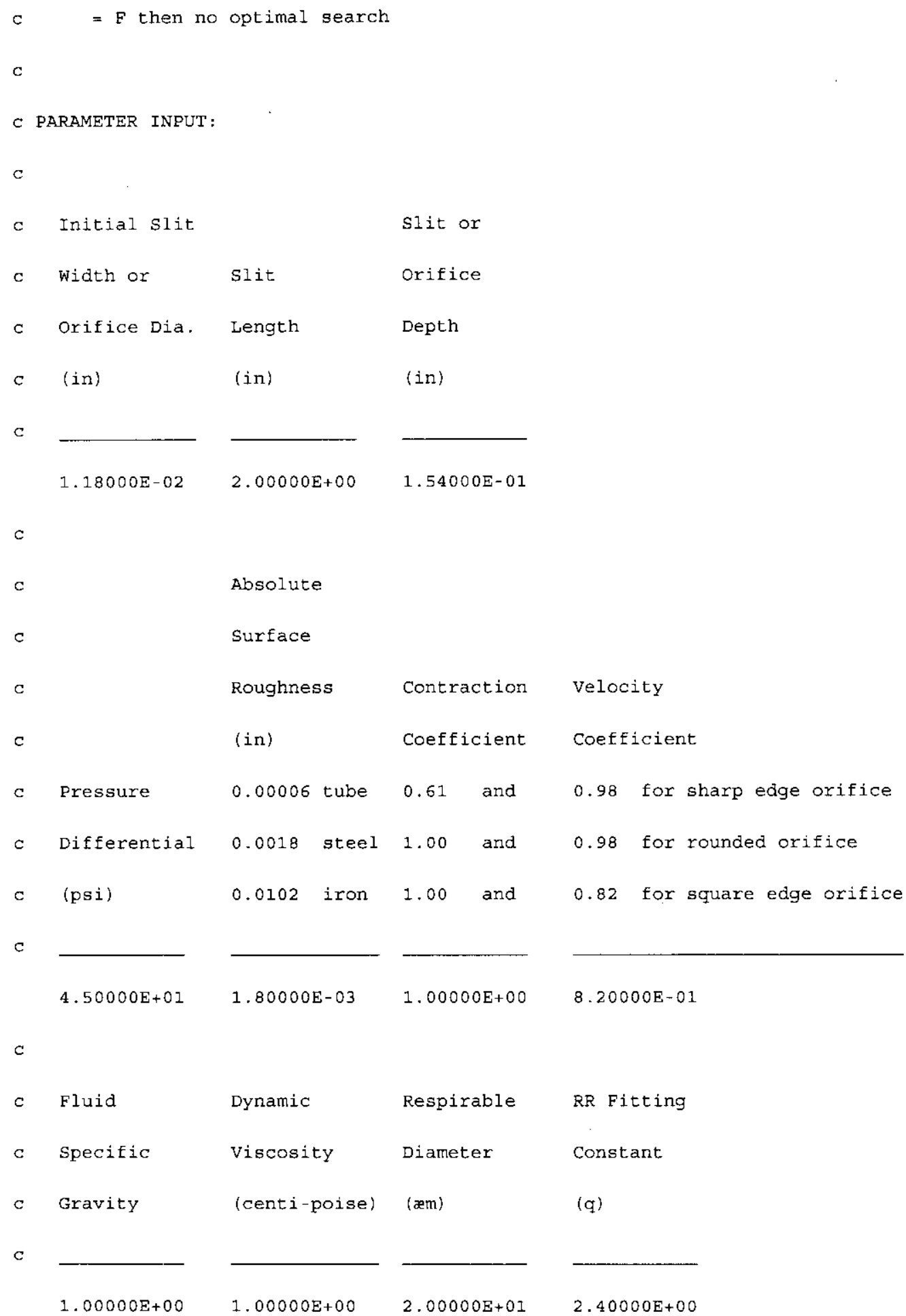

MESSAGES :

slit Model 
SNF-10272 REV. 2

User specified orifice diameter or slit width.

OUTPUT :

Liquid velocity $=5.67 \mathrm{E}+01 \mathrm{ft} / \mathrm{s} \quad 1.73 \mathrm{E}+01 \mathrm{~m} / \mathrm{s}$

Reynolds Number $=1.03 \mathrm{E}+04$ Turbulent Flow

Sauter Mean Diameter $=2.46 \mathrm{E}+02 æ \mathrm{~m}$

Respirable Fraction $=8.73 \mathrm{E}-04$

Total Leak Rate $=4 \cdot 17 \mathrm{E}+00 \mathrm{gpm}$

$2.63 \mathrm{E}-04 \mathrm{~m} 3 / \mathrm{s}$

$2.63 \mathrm{E}+02 \mathrm{~g} / \mathrm{s}$

Respirable Leak Rate $=3.64 \mathrm{E}-03 \mathrm{gpm}$

$2.30 \mathrm{E}-07 \mathrm{~m} 3 / \mathrm{s}$

$2.30 \mathrm{E}-01 \mathrm{~g} / \mathrm{s}$ 
SNF-10272 REV. 2

\section{APPENDIX B - FINAL PRESSURE IN THE LDC DUE TO HYDROGEN BURNS}

This appendix provides the final pressure and temperature as a result of hydrogen burns in air and argon. The results are used to determine which accident is bounding.

The final pressure in the LDC due to a hydrogen burn is found as follows.

The volume of the LDC open area is chosen. The moles of argon (or other gas) in the space is found using the ideal gas law. For this calculation, the initial pressure within the LDC is chosen to be $10 \mathrm{psig}$. This is above the proposed operating pressure of between 4 and 5 psig. It is conservative to have a greater initial pressure, as the final pressure will be greater. The initial temperature is chosen to be $25 \mathrm{C}(298 \mathrm{~K})$. This is also conservative in that higher initial temperatures result in higher final pressures. The maximum volume above the liquid is taken to be $1600 \mathrm{~L}$. This exceeds the minimum volume of $1200 \mathrm{~L}$. It is used because it maximizes the amount of hydrogen in the LDC, thus maximizing the burn energy.

The number of moles of the gas is found from:

$$
\begin{aligned}
& \mathrm{n}=\frac{P V}{R T} \\
& \text { where } \quad \begin{aligned}
\mathrm{P} & =\text { initial pressure, atm } \\
& =1.68 \text { atm }(10 \mathrm{psig}) \\
\mathrm{V} & =\text { initial open volume, } \mathrm{L} \\
\mathrm{R} & =0.082 \mathrm{~L}-\mathrm{atm} / \text { mole- } \mathrm{K} \\
\mathrm{T} & =\text { initial temperature, } \mathrm{K} \\
& =298 .
\end{aligned}
\end{aligned}
$$

Next, hydrogen and oxygen are allowed to accumulate with in the LDC open volume.

\section{Argon in Headspace - Hydrogen Generation Twice Oxygen Generation}

In this first case, the hydrogen and oxygen are generated in a ratio of $2: 1$, equal to that if only radiolysis occurred or if the chemical reaction of hydrogen were delayed for a long period of time. The quantity of hydrogen is chosen to be 0.3 times the final gas quantity $(0.3$ mole fraction of the final gas, i.e., the stoichiometric mix that gives the greatest energy yield). The amount of gas present just before the burn is given by:

$$
\begin{aligned}
& a+b+x+(x / 2)=y \\
& x=0.3 * y
\end{aligned}
$$


where: $\quad a=$ moles of inert gas present initially

$\mathrm{b}=$ moles of air present initially

$\mathrm{x}=$ moles of hydrogen at the end of accumulation (assuming that hydrogen is produced by radiolysis at $0.028 \mathrm{moles} / \mathrm{hr}$ per

Section 3.4.3)

$\mathrm{x} / 2=$ moles of oxygen (assuming that oxygen is produced in a ratio of 1:2)

The first equation, the constants "a" and "b" are known. They are the moles of the gas initially present. The term " $y$ " is the total moles in the LDC at the end of the hydrogen and oxygen accumulation. Substituting for " $\mathrm{x}$ " yields:

$$
a+b+0.3 y+0.15 y=y
$$

or,

$$
\mathrm{a}+\mathrm{b}=0.55 \mathrm{y}
$$

Solving for " $y$ " yields:

$$
y=(a+b) / 0.55
$$

The moles of hydrogen is found from:

$$
\mathrm{x}=0.3 * \mathrm{y}
$$

The moles of oxygen is found from:

$$
\text { Oxygen }=x / 2
$$

The new initial pressure is calculated using the total moles of the initial gas, plus the moles of hydrogen and that for oxygen.

The burn energy for hydrogen is $28,600 \mathrm{cal} / \mathrm{gram}$ from Table 4.3 of Introduction to Combustion Phenomena. The burn energy for the case being analyzed is found from:

$$
\mathrm{Q}=(\text { number of moles of hydrogen }) *(2 \mathrm{~g} / \mathrm{mole}) *(28600 \mathrm{cal} / \mathrm{g})
$$

The temperature rise due to the burn is found from:

$$
\Delta \mathrm{T}=\frac{Q}{\sum n_{i} c_{v i}}
$$

where

$$
\begin{aligned}
& n_{i}=\text { number of moles of the gas " } i \text { " } \\
& c_{v i}=\text { specific heat at constant volume for gas " } i \text { ", cal / mole-K }
\end{aligned}
$$


Handbook values for specific heat are given for constant pressure. To change to constant volume, the following must be done:

$$
\begin{aligned}
& c_{v}=c_{p}-R \\
& \text { where } \quad R=1.987 \mathrm{cal} / \text { mole- } K
\end{aligned}
$$

The Handbook values for specific heat at constant pressure, in units of cal / mole- $\mathrm{K}$, for the gases of interest are:
Argon
Nitrogen
$6.5+0.001 * \mathrm{~T}$
Oxygen
$8.27+0.000258 * \mathrm{~T}-187700 / \mathrm{T}^{2}$
Water Vapor
$8.22+0.00015 * \mathrm{~T}+0.00000134 * \mathrm{~T}^{2}$

To obtain specific heat at constant volume, "R" must be subtracted from these values.

Typically, the average temperature is used in the formulas for specific heat. This necessitates an iterative solution in which an average temperature is chosen and the specific heats are determined. These are entered in the equation for $\Delta \mathrm{T}$. The final temperature is found by adding the initial temperature to $\Delta \mathrm{T}$. The average temperature is the average of the final and initial temperature. The new average temperature is than used in the equation for the specific heat.

In the second case, hydrogen is assumed to be 0.15 in the final mix. A mole fraction of 0.15 is the lower limit for a mixture that can detonate (should that be necessary to consider). The third case is 0.08 mole fraction of hydrogen (along with 0.04 mole fraction oxygen), the approximate lower flammability limit in argon.

For the 0.15 mole fraction case, the moles of total gas found from:

$$
y=(a+b) / 0.775
$$

The moles of hydrogen is found from:

$$
\mathrm{x}=0.15^{*} \mathrm{y}
$$

The number of moles of oxygen is found from " $\mathrm{x} / 2$ ".

For the 0.08 mole fraction case, the moles of total gas is found from:

$$
y=(a+b) / 0.88
$$

The moles of hydrogen is found from:

$$
x=0.08 * y
$$


The number of moles of oxygen is found from " $\mathrm{x} / 2$ ".

\section{Air in Headspace - Hydrogen Generation 37 times Oxygen Generation}

The spreadsheet was modified to account for the relatively lower quantity of oxygen in the gas being produced. This case corresponds to the safety basis chemical generation of hydrogen at $25 \mathrm{C}$ and production of hydrogen and oxygen by radiolysis per Section 3.4.3. Again assuming a 0.3 hydrogen mole fraction, the total quantity of gas just prior to burn is given by:

$$
\begin{gathered}
a+b+x+(x / 37)=y \\
x=0.3^{*} y
\end{gathered}
$$

where: $\quad a=$ moles of inert gas present initially

$\mathrm{b}=$ moles of air present initially

$\mathrm{x}=$ moles of hydrogen at the end of accumulation

$\mathrm{x} / 37=$ moles of oxygen (assuming that oxygen is produced by radiolysis at $0.014 \mathrm{moles} / \mathrm{hr}$ and hydrogen is produced at $0.518 \mathrm{moles} / \mathrm{hr}$ per Section 3.4.3).)

In the first equation the constants "a" and "b" are known. They are the moles of the gas initially present. The term " $y$ " is the total moles in the LDC at the end of the hydrogen and oxygen accumulation. Substituting for " $x$ " yields:

$$
a+b+0.3 y+0.00811 y=y
$$

or,

$$
a+b=0.692 y
$$

Solving for " $y$ " yields:

$$
y=(a+b) / 0.692
$$

The moles of hydrogen is found from:

$$
\mathrm{x}=0.3 * \mathrm{y}
$$

The moles of oxygen is found from:

$$
\text { Oxygen }=x / 37
$$

For the case where the mole fraction of hydrogen is 0.15 , the equation is

$$
a+b+x+(x / 37)=y
$$




$$
\mathrm{x}=0.15 \mathrm{y}
$$

Therefore,

$$
\begin{aligned}
& a+b+0.15 y+0.00405 y=y \\
& y=(a+b) / 0.846 \\
& x+0.15 y\left(H_{2} \text { fraction }\right) \\
& \mathrm{O}_{2}=x / 37
\end{aligned}
$$

Table A-1 presents the cases run. Table A-2 presents the results.

Table A-1 Cases Run

\begin{tabular}{|l|l|l|l|l|l|}
\hline Case Number & $\begin{array}{l}\text { LDC Headspace } \\
\text { volume, } \mathrm{L}\end{array}$ & $\begin{array}{l}\text { Final Hydrogen } \\
\text { Fraction }\end{array}$ & $\begin{array}{l}\text { LDC } \\
\text { Environment }\end{array}$ & $\begin{array}{l}\text { Hydrogen and } \\
\text { Oxygen } \\
\text { generation type }\end{array}$ & $\begin{array}{l}\text { Spreadsheet } \\
\text { results attached } \\
\text { below? }\end{array}$ \\
\hline 1 & 1600 & 0.3 & Air & $\begin{array}{l}\text { Chemical plus } \\
\text { Rad }\end{array}$ & No \\
\hline $2 \mathrm{a}$ & 1200 & 0.3 & Air & $\begin{array}{l}\text { Chemical plus } \\
\text { Rad }\end{array}$ & Yes \\
\hline $2 \mathrm{~b}$ & 1200 & 0.3 & Air & $\begin{array}{l}\text { Hydrogen, but } \\
\text { no oxygen added }\end{array}$ & Yes \\
\hline 3 & 1600 & 0.15 & Air & $\begin{array}{l}\text { Chemical plus } \\
\text { Rad }\end{array}$ & No \\
\hline 4 & 1200 & 0.15 & Air & $\begin{array}{l}\text { Chemical plus } \\
\text { Rad }\end{array}$ & Yes \\
\hline 5 & 100 & 0.3 & Air & $\begin{array}{l}\text { Chemical plus } \\
\text { Rad }\end{array}$ & No \\
\hline 6 & 500 & 0.3 & Air & $\begin{array}{l}\text { Chemical plus } \\
\text { Rad }\end{array}$ & No \\
\hline 7 & 1600 & 0.3 & Argon & Rad Only & No \\
\hline 8 & 1200 & 0.3 & Argon & Rad Only & Yes \\
\hline 9 & 1600 & 0.15 & Argon & Rad Only & No \\
\hline 10 & 1200 & 0.15 & Argon & Rad Only & Yes \\
\hline 11 & 500 & 0.3 & Argon & Rad Only & No \\
\hline 12 & 100 & 0.3 & Air & Rad Only & Yes \\
\hline 13 & 500 & 0.3 & Air & Rad Only & No \\
\hline 14 & 100 & 0.08 & Argon & Rad Only & No \\
\hline 15 & 100 & 0.15 & Argon & Rad Only & No \\
\hline & & & & \\
\hline
\end{tabular}


Table A-2. Results of Hydrogen Burns

\begin{tabular}{|c|c|c|c|c|c|c|c|}
\hline Case & $\begin{array}{l}\text { LDC } \\
\text { Headspace } \\
\text { volume (air } \\
\text { filled or } \\
\text { Argon filled), } \\
\text { L } \\
\end{array}$ & $\mathrm{H}_{2}$ Fraction & $\begin{array}{l}\text { Moles of } \\
\text { Hydrogen } \\
\text { added }\end{array}$ & $\begin{array}{l}\text { Moles of oxygen } \\
\text { added }\end{array}$ & $\begin{array}{l}\text { Pressure after } \\
\mathrm{H}_{2} \text { and } \mathrm{O}_{2} \\
\text { Addition, atm }\end{array}$ & $\begin{array}{l}\text { Final } \\
\text { Pressure } \\
\text { after burn, } \\
\text { psig }\end{array}$ & $\begin{array}{l}\text { Avg. } \\
\text { Temp. } \\
\text { for Burn } \\
\text { Calc. }\end{array}$ \\
\hline 1 & 1600 & 0.3 & 47.7 & 1.3 & 2.4 & 288 & 1637 \\
\hline $2 a$ & 1200 & 0.3 & 35.8 & 1.0 & 2.4 & 288 & 1637 \\
\hline $2 b$ & 1200 & 0.3 & 35.4 & 0.0 & 2.4 & 285 & 1637 \\
\hline 3 & 1600 & 0.15 & 19.5 & 0.5 & 1.99 & 151 & 1064 \\
\hline 4 & 1200 & 0.15 & 14.6 & 0.4 & 1.99 & 151 & 1064 \\
\hline 5 & 100 & 0.3 & 2.98 & 0.08 & 2.4 & 288 & 1637 \\
\hline 6 & 500 & 0.3 & 14.9 & 0.4 & 2.4 & 288 & 1637 \\
\hline 7 & 1600 & 0.3 & 60 & 30 & 3.05 & 450 & 1964 \\
\hline 8 & 1200 & 0.3 & 45 & 22.5 & 3.05 & 450 & 1964 \\
\hline 9 & 1600 & 0.15 & 21.3 & 10.6 & 2.2 & 244 & 1456 \\
\hline 10 & 1200 & 0.15 & 16 & 8 & 2.2 & 244 & 1456 \\
\hline 11 & 500 & 0.3 & 18.8 & 9.4 & 3.05 & 450 & 1964 \\
\hline 12 & 100 & 0.3 & 3.7 & 1.9 & 3.05 & 364 & 1629 \\
\hline 13 & 500 & 0.3 & 18.8 & 9.4 & 3.05 & 364 & 1629 \\
\hline 14 & 100 & 0.08 & 0.62 & 0.31 & 1.9 & 140 & 1003 \\
\hline 15 & 100 & 0.15 & 1.33 & 0.66 & 2.2 & 244 & 1456 \\
\hline
\end{tabular}

\section{Reference:}

Introduction to Combustion Phenomena, 1975, Gordon and Breach Science Publishers, New York, New York. 
SNF-10272 REV. 2

\section{CASE 2a}

Chemical plus Rad Case

Final Pressure, Temperature as a Function

of Initial Pressure and Air Volume Size

(K Basin LDC)

\section{Air in the LDC. H2 and $\mathrm{O} 2$ gradually enter the air.}

Chosen volume of initial air ingress, $L$ Initial pressure, atm, abs Initial temperature. $\mathrm{K}$ Open volume, LDC, L

$\begin{array}{rl} & 1200 \\ 1.68 & 9.996 \mathrm{psig} \\ 298 & \\ 1200 & \end{array}$

specific heat at constant volume, cal/mole-K (Found from Handbook values [which are $\mathrm{Cp}$ ] Temp. volume, I moles during burn, $\mathrm{K}$

$\begin{array}{lrrrr}\mathrm{Ar} & 0 & 0 & 1637 & 2.983 \\ \mathrm{~N} 2 & 948 & 65: 17597 & 1637 & 6.15 \\ \mathrm{O} 2 & 252 & 17.32526 & 1637 & 6.635303 \\ \mathrm{H} 2 \mathrm{O} & & & 1637 & 10.06944\end{array}$

Now Hydrogen and $\mathrm{O} 2$ build in from radiolysis such that $\mathrm{H} 2$ is 0.3 in the air-argon mix
after the hydrogen and oxygen accumulate in it (l.e., 0.3 of the final gas mix)
$\mathrm{H} 2$ from radiolysis $\quad 35.76643$ moles
$\mathrm{O} 2$ from radiolysis
Check that hydrogen is 0.3 of the mixture $\quad 0.296966$ moles

New initial pressure due to $\mathrm{H} 2$ and $\mathrm{O} 2$ flow to headspace, atm.abs $\quad 2.428008$

Final press. atm,abs. $\quad 20.61686$

Final pressure, psig $\quad 288.3678$ 
SNF-10272 REV. 2

\author{
CASE 2b - No oxygen added \\ Chemical plus Rad Case \\ Final Pressure, Temperature as a Function \\ of Initial Pressure and Air Volume Size \\ (K Basin LDC)
}

Air in the LDC. H2 and $\mathrm{O} 2$ gradually enter the air.

Chosen volume of initial air ingress, $L$

1200

Initial pressure, atm, abs

Initial temperature. $\mathrm{K}$

$1.689 .996 \mathrm{psig}$

Open volume, LDC, L

298

1200

\begin{tabular}{|c|c|c|c|c|}
\hline \multirow[b]{2}{*}{$\operatorname{Ar}$} & \multicolumn{2}{|c|}{ volume, I moles } & e & $\begin{array}{l}\text { specific heat at constant volume, cal/mole-K } \\
\text { (Found from Handbook values [which are } \mathrm{Cp} \text { ] } \\
\text { minus } 1.987 \text { ) }\end{array}$ \\
\hline & 0 & 0 & 1636 & 2.983 \\
\hline N2 & 948 & 65.17597 & 1636 & 6.149 \\
\hline $\mathrm{O} 2$ & 252 & 17.32526 & 1636 & 6.634959 \\
\hline $\mathrm{H} 2 \mathrm{O}$ & & & 1636 & 10.0649 \\
\hline
\end{tabular}

Now Hydrogen and $\mathrm{O} 2$ build in from radiolysis such that $\mathrm{H} 2$ is 0.3 in the air-argon mix after the hydrogen and oxygen accumulate in it (l.e., 0.3 of the final gas mix)

$\mathrm{H} 2$ from radiolysis

35.35767 moles

(Divisor is 0.7 ot 0.692 )

$\mathrm{O} 2$ from radiolysis

0 moles

Check that hydrogen is 0.3 of the mixture

(Set equal to Zero for no oxygen flow to LDC)

0.3

New initial pressure due to $\mathrm{H} 2$ and $\mathrm{O} 2$ flow to headspace, atm.abs

2.4

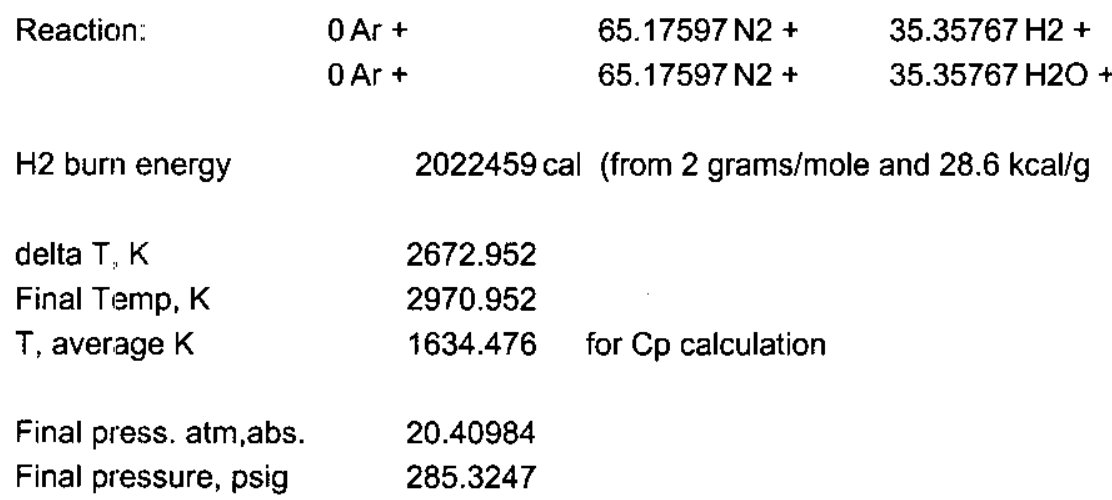


CASE 4

Chemical plus Rad Case

Final Pressure, Temperature as a Function

of Initial Pressure and Air Volume Size

(K Basin LDC)

Air in the LDC. H2 and $\mathrm{O} 2$ gradually enter the air.

$\begin{array}{lrc}\text { Chosen volume of initial air ingress, } \mathrm{L} & & 1200 \\ \text { Initial pressure, atm, abs } & 1.68 & 9.996 \mathrm{psig} \\ \text { Initial temperature. K } & 298 & \\ \text { Open volume, LDC, L } & 1200 & \end{array}$

\begin{tabular}{|c|c|c|c|c|}
\hline & volume, 1 & moles & $\begin{array}{l}\text { Average } \\
\text { Temp. } \\
\text { during burn, } \mathrm{K}\end{array}$ & $\begin{array}{l}\text { specific heat at constant volume, cal } / \text { mole- } \mathrm{K} \\
\text { (Found from Handbook values [which are } \mathrm{Cp} \text {. } \\
\text { minus } 1.987 \text { ) }\end{array}$ \\
\hline $\operatorname{Ar}$ & 0 & 0 & 1064 & 2.983 \\
\hline N2 & 948 & 65.17597 & 1064 & 5.577 \\
\hline $\mathrm{O} 2$ & 252 & 17.32526 & 1064 & 6.391713 \\
\hline $\mathrm{H} 2 \mathrm{O}$ & & & 1064 & 7.909609 \\
\hline
\end{tabular}

Now Hydrogen and $\mathrm{O} 2$ build in from radiolysis such that $\mathrm{H} 2$ is 0.15 in the air-argon mix after the hydrogen and oxygen accumulate in it (l.e., 0.15 of the final gas mix)

$\mathrm{H} 2$ from radiolysis 14.62788 moles (Divisor is 0.692)

$\mathrm{O} 2$ from radiolysis $\quad 0.395348$ moles

Check that hydrogen is 0.15 of the mixture $\quad 0.149992$

New initial pressure due to $\mathrm{H} 2$ and $\mathrm{O} 2$ flow to headspace, atm.abs 1.985923

$\begin{array}{lllll}\text { Reaction: } & \mathrm{OAr}+ & 65.17597 \mathrm{~N} 2+ & 14.62788 \mathrm{H} 2+ & 17.72061 \mathrm{O} 2 \text {-> } \\ & \mathrm{OAr}+ & 65.17597 \mathrm{~N} 2+ & 14.62788 \mathrm{H} 2 \mathrm{O}+ & 10.40667 \mathrm{O} 2\end{array}$

H2 burn energy $\quad 836714.6 \mathrm{cal}$ (from $2 \mathrm{grams} / \mathrm{mole}$ and $28.6 \mathrm{kcal} / \mathrm{g}$

delta $T, K \quad 1533.277$

Final Temp, K $\quad 1831.277$

$\mathrm{T}$, average $\mathrm{K} \quad 1064.638$ for $\mathrm{Cp}$ calculation

Final press. atm,abs. $\quad 11.28869$

Final pressure, psig $\quad 151.2438$ 


\title{
SNF-10272 REV. 2
}

\author{
Case 8 \\ Rad Only Case \\ Final Pressure, Temperature as a Function \\ of Initial Pressure and Void Size \\ (K Basin LDC)
}

Void is due to a partial decant, but is filled, initially, with argon. $\mathrm{H} 2$ and $\mathrm{O} 2$ then gradually enter the argon.

Chosen void space due to partial decant, $L$ Initial pressure, atm, abs Initial temperature. $\mathrm{K}$
$1.68 \quad 9.996 \mathrm{psig}$

298

Specific heat at constant volume, (cal/mole-K). Found from Handbook values [which are $\mathrm{Cp}$ ] minus 1.987) 2.983

6.741051

11.69638

$\mathrm{H} 2 \mathrm{O}$

volume, I moles during burn, $\mathrm{K}$ $1200 \quad 82.50123$

1964

1964

Now Hydrogen and $\mathrm{O} 2$ build in from radiolysis such that $\mathrm{H} 2$ is 0.30 in the void volume after it accumulates (I.e., 0.30 of the final gas quantity) $\mathrm{H} 2$, radiolysis, moles 45.00067

O2,radiolysis, moles 22.50033

New initial pressure due to $\mathrm{H} 2$ and $\mathrm{O} 2$ flow to headspace, atm.abs

Reaction:

$82.50123 \mathrm{Ar}+$

$45.00067 \mathrm{H} 2+$

82.50123 $\mathrm{Ar}+$ $45.00067 \mathrm{H} 2 \mathrm{O}+$

H2 burn energy

delta $\mathrm{T}, \mathrm{K}$

Final Temp, $\mathrm{K}$

$T$, average $K$

Final press. atm,abs.

Final pressure, psig
$2574038 \mathrm{cal}$ (from $2 \mathrm{grams} / \mathrm{mole}$ and $28.6 \mathrm{kcal} / \mathrm{g}$

3332.322

3630.322

1964.161 for Cp calculation

31.62965

450.2558 


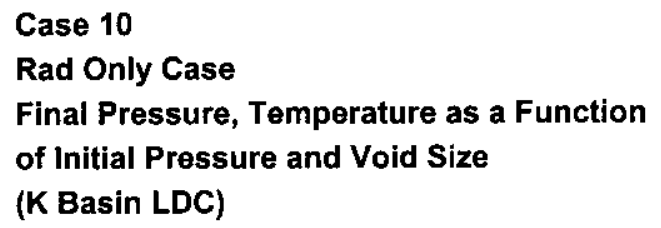

Void is due to a partial decant, but is filled, initially, with argon. $\mathrm{H} 2$ and $\mathrm{O} 2$ then gradually enter the argon.

Chosen void space due to partial decant, $\mathrm{L}$ Initial pressure, atm, abs Initial temperature. $\mathrm{K}$

$\begin{array}{cc} & 1200 \\ 1.68 & 9.996 \text { psig } \\ 298 & \end{array}$

Specific heat at constant volume, (cal/mole-K). Found from Handbook values [which are $\mathrm{Cp}$ ] minus 1.987)

1456

1456

2.983

6.570108

9.292114

Now Hydrogen and $\mathrm{O} 2$ build in from radiolysis such that $\mathrm{H} 2$ is 0.15 in the void volume after it accumulates (1.e., 0.15 of the final gas quantity)

$\mathrm{H} 2$, radiolysis, moles

15.96798

02 ,radiolysis, moles

7.98399

New initial pressure due to $\mathrm{H} 2$ and $\mathrm{O} 2$ flow to headspace, atm.abs

Reaction

$$
\begin{aligned}
& \text { 82.50123 } \mathrm{Ar}+ \\
& \text { 82.50123 } \mathrm{Ar}+
\end{aligned}
$$$$
15.96798 \mathrm{H} 2+
$$$$
15.96798 \mathrm{H} 2 \mathrm{O}+
$$

7.9839902 ->

002

H2 burn energy

delta $T, K$

Final Temp, $\mathrm{K}$

$\mathrm{T}$, average $\mathrm{K}$

Final press. atm,abs.

Final pressure, psig
$913368.4 \mathrm{cal}$ (from $2 \mathrm{grams} / \mathrm{mole}$ and $28.6 \mathrm{kcal} / \mathrm{g}$

2315.388

2613.388

1455.694 for Cp calculation

17.58478

243.7963 


\section{CASE 12 \\ Rad Only Case \\ Final Pressure, Temperature as a Function \\ of Initial Pressure and Air Volume Size \\ (K Basin LDC)}

Air in the LDC. $\mathrm{H} 2$ and $\mathrm{O} 2$ gradually enter the air.

Chosen volume of initial air ingress, $L$

100

Initial pressure, atm, abs

$1.68 \quad 9.996 \mathrm{psig}$

Initial temperature. $\mathrm{K}$

298

Open volume, LDC, L

100

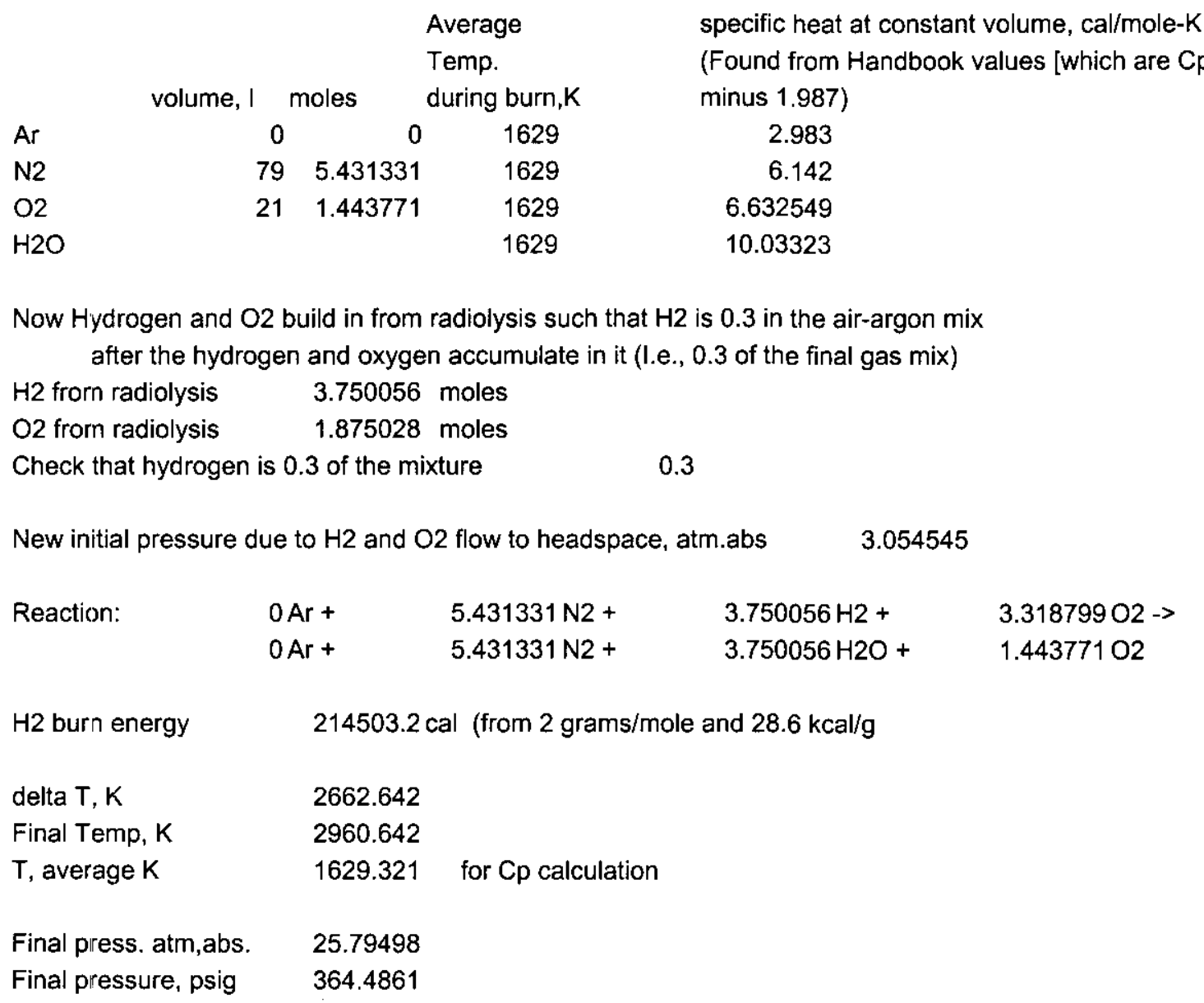




\section{APPENDIX C - LDC BURST PRESSURE AND MINIMUM VOID VOLUME}

When the LDC pressurizes, it expands. Expansion to the point where it fails is considered unacceptable. Section 3.4.7.2 shows that the LDC design pressure is 150 psig. The LDC has been hydrostatically tested to $225 \mathrm{psig}$. Assume the LDC pressure is $850 \mathrm{psig}$ (shown below to be the burst pressure).

The change in dimensions due to pressurization is found using Roark's Formulas for Stress and Strain. These changes are based on elastic conditions and the assumption of an empty vessel experiencing a slowly increasing pressure. While that is not the case in hydrogen burns, the results do give an indication of the change in dimensions. Table 28 , Case $1 \mathrm{c}$ of the reference shows that for thin cylindrical vessels with capped ends (a conservative case with respect to the LDC)

$$
\begin{gathered}
\Delta \mathrm{R}=\frac{q R^{2}}{E t}\left(1-\frac{v}{2}\right) \\
\Delta \mathrm{y}=\frac{q R y}{E t}(0.5-v)
\end{gathered}
$$

Where $\mathrm{q}=$ internal pressure, $\mathrm{psig}$

$$
\begin{aligned}
& =850 \text { psig } \\
R & =\text { radius of vessel, in. } \\
& =29.5 \text { inches } \\
\mathrm{E} & =\text { modules of elasticity, psi } \\
& =28 \times 10^{6} \text { for austenitic stainless steel ( } 300 \text { series) } \\
v & =\text { Poisson's Ratio } \\
& =0.3 \text { for stainless steel } \\
\mathrm{y} & =\text { length of vessel, in. } \\
& =106 \text { in. (base to ports) } \\
\mathrm{t} & =\text { wall thickness, in. } \\
& =0.5
\end{aligned}
$$

Solving yields

$$
\Delta \mathrm{R}=0.045 \mathrm{in} .
$$




$$
\Delta y=0.038 \text { in } .
$$

The volume prior to expansion is $289,800 \mathrm{in}^{3}$.

The volume after expansion is $290,790 \mathrm{in}^{3}$.

The change in volume is $990 \mathrm{in}^{3}$ or $16.2 \mathrm{~L}$.

There are a number of ways to determine the burst pressure. The first is that ASME Section II, Appendix 1, Part D indicates that the safety factor for stainless steel is 3.5. This means that the LDC may burst at $525 \mathrm{psig}$ (from 3.5 times $150 \mathrm{psig}$ ).

The text Pressure Vessel Design and Analysis, page 386, presents a derivation of the bursting pressure for a thin-walled cylindrical vessel based on instability analysis. The burst pressure for $18 \mathrm{Cr}-8 \mathrm{Ni}$ steel (304 stainless steel) is found from

$$
P=60,000 t_{0} / r_{o}
$$

$$
\text { Where } \begin{aligned}
\mathrm{t}_{\mathrm{o}} & =\text { thickness, in. } \\
& =0.5 \mathrm{in} . \\
\mathrm{r}_{\mathrm{o}} & =\text { radius of vessel, in. }
\end{aligned}
$$

29.5

Solving for "P" yields $1017 \mathrm{psi}$.

Second, the design stress analysis for the LDC is used. AVANTech Calculation EN-3C-012604, K-East Bain Sludge Transport System-A-170 (Large Container): Structural Analysis (90\% Final Design), provides the stress analysis for the LDC. The LDC is constructed of Type 316 stainless steel (18 Cr-12 Ni-2 Mo). The stress analysis, performed using ASME Section VIII, Division 1 methods at $200 \mathrm{~F}$ shows that the:

- Thickness of the upper ellipsoidal head need only be $0.284 \mathrm{in}$. The head is $0.75 \mathrm{in}$. Using 0.125 inch corrosion allowance and $12.5 \%$ tolerance on the milling ( 0.094 in.), yields an actual minimum wall thickness of 0.531 in. or almost twice as thick as it needs to be. The $12.5 \%$ mill tolerance comes from the ASME Code assumption that $12.5 \%$ is the maximum allowable variation from the nominal material thickness as a result of the manufacturing process per the applicable ASTM Standard

- The thickness of the shell needs to be 0.286 in. The shell thickness is $0.5 \mathrm{in}$. Using the same corrosion and mill tolerance as above yields 0.313 in. The wall is almost $10 \%$ thicker than it needs to be.

- The lower ellipsoidal head is very similar to the upper ellipsoidal head.

The analysis also shows that the nozzles are reinforced. Therefore, the weakest point is the shell.

The time of concern for LDC bursting is well before 30 years of corrosion has occurred.

Therefore the wall thickness of 0.5 minus the mill tolerance of $12.5 \%$ (0.063 in) or $0.438 \mathrm{in}$. can 
be used to determine the design pressure early in life. It should be noted that the measured LDC wall thickness found during an inspection of welds was in excess of 0.5 inches, not less than 0.5 inches. Section 7.2 of the calculation shows that the wall thickness is found from

$$
\mathrm{t}=\frac{P R}{S E_{j}-0.60 P}
$$

$$
\begin{aligned}
& \text { Where } \mathrm{P}=\text { design pressure, } \mathrm{psig} \\
& \mathrm{R}=\text { radius, in . } \\
& =29.5 \mathrm{in} \text {. } \\
& \mathrm{S}=\text { design stress intensity at } 200 \mathrm{~F} \text { per the AVANTech Calculation } \\
& =17,300 \mathrm{psi} \text { (See discussion below) } \\
& E_{j}=\text { joint efficiency } \\
& =0.9 \text { per the reference. }
\end{aligned}
$$

Solving for "P" yields $229 \mathrm{psi}$.

Using the safety factor of 3.5 from ASME Section II, appendix 1, Part D yields a burst pressure of 802 psi (using properties based on $200 \mathrm{~F}$ ). Using the correlation from the text Pressure Vessel Design and Analysis with $\mathrm{r}_{\mathrm{o}}$ equal to 0.438 in. yields a burst pressure of $891 \mathrm{psi}$. A burst pressure of $850 \mathrm{psi}$ will be used in the analysis.

The burst pressure of 850 psi meets the ASME method as the LDC temperatures do not approach $200 \mathrm{~F}$. At lower temperatures the allowable stress is greater. At $100 \mathrm{~F}$ and below, Table 3-01 of the AVANTech calculation shows Design Stress Intensity of 20,000 psi. At $200 \mathrm{~F}$ it is 17,300 psi or $15 \%$ lower. The LDC temperature ranges below $100 \mathrm{~F}$ except for the worst case transportation scenario when the peak temperature is $134^{\circ} \mathrm{F}$ (SNF-9955, Safety-Basis Thermal Analysis for KE Basin Sludge Transport and Storage).

Next the effect on bursting due to a hydrogen burn in a filled LDC will be determined. Assume the sludge volume is $2 \mathrm{~m}^{3}$. The sludge is $75 \%$ water by volume per HNF-SD-SNF-TI-015, SNF Project Technical Databook, Volume 2, Sludge.

The water mass is $1500 \mathrm{~kg}$. The hydrogen burn in an LDC having a headspace volume of $1600 \mathrm{~L}$ and having an air environment releases $2.7 \times 10^{6} \mathrm{cal}$ (Case 1 from Appendix B). The water and the LDC steel will absorb all of that energy. Using just the water, the final temperature after heat transfer is

$$
2.7 \times 10^{6} \mathrm{cal}=(1500 \mathrm{~kg})(1000 \mathrm{~g} / \mathrm{kg})(1 \mathrm{cal} / \mathrm{g}-\mathrm{C}) \Delta \mathrm{T}
$$

Solving for $\Delta \mathrm{T}$ yields $1.8 \mathrm{C}$. The $\mathrm{LDC}$ temperature does not vary much from the initial temperature. 
The burst pressure calculations show that the LDC can absorb energy prior to burst. The energy absorbed is

$$
\mathrm{E}=\mathrm{P} \Delta \mathrm{V}
$$

Where $\mathrm{P}=$ pressure, $\mathrm{N} / \mathrm{m}^{2}$

$$
\begin{aligned}
& =(850 \mathrm{psig}+14.7) / 14.7)\left(101320 \mathrm{~Pa} /\left[\mathrm{N}-\mathrm{m}^{2}\right]\right) \\
& =5.96 \times 10^{6} \mathrm{~N} / \mathrm{m}^{2} \\
& \Delta \mathrm{V}=\text { change in volume, } \mathrm{m}^{3} \\
& =0.016 \mathrm{~m}^{3} \text { (from the volume calculation above) }
\end{aligned}
$$

Solving for "E" yields $9.5 \times 10^{4} \mathrm{~N}-\mathrm{m}$. An energy expenditure of $9.5 \times 10^{4} \mathrm{~N}-\mathrm{m}$ by the expanding gas will burst the vessel.

If in Case 1 the hydrogen burns instead of detonates from $1.68 \mathrm{~atm}, 298 \mathrm{~K}$, in a $1600 \mathrm{~L} \mathrm{LDC}$ headspace. The peak pressure is $285 \mathrm{psig}$. The final temperature is $2977 \mathrm{~K}$. The energy release is $2.7 \times 10^{6}$ cal or $11.5 \times 10^{6} \mathrm{~J}\left(11.5 \times 10^{6} \mathrm{~N}-\mathrm{m}\right)$. Most of the energy goes into heating the air and reaction products. Applying a dynamic load factor of 2 on the pressure or $285 \mathrm{psig}$, (based on Section 3.4.7), yields $570 \mathrm{psig}$. The pressure does not exceed the burst pressure if a detonation does not occur.

Now, consider a case in which a burn occurs in a smaller volume. Section 3.4.7.2 argues that if the $\mathrm{LDC}$ volume is $400 \mathrm{~L}$ or less, a detonation does not occur. Therefore, the LDC will remain intact for all hydrogen burns in volumes $400 \mathrm{~L}$ or less.

The other area of concern is the fittings and hoses on the top of the LDC. The fittings and hoses are rated for the design pressure. In small volumes, the burn is close to the fittings. Therefore, it is possible that the stresses will be greater for some period of time until they equalize out over the entire LDC. To cover uncertainties regarding this effect, the minimum volume in which a hydrogen burn could occur and not result in conditions exceeding those of design is judged to be half of the $400 \mathrm{~L}$ above or $200 \mathrm{~L}$. The value was decreased from that shown not to fail the LDC $(400 \mathrm{~L})$ because the products of the burn and the pressure pulse is close to the hose and hose connections. This volume corresponds to the level somewhat greater than the base of the ellipsoidal head and is well above the sludge filters. There are no ignition sources in this space except for potential for static build up on the argon entry and exit port. The humidity will also be high in the $200 \mathrm{~L}$ headspace. This makes the likelihood of a spark even by static discharge extremely unlikely.

A burn in a volume of $200 \mathrm{~L}$ or less is not expected to result in loss of confinement as it is assumed that the hose attached to the nozzle connections can also withstand the pressure experienced. The hoses can withstand the design pressure and more. Since the reaction is not a detonation (due to the small volume and lack of obstacles), there is no associated pressure increase over that of the burn. The dynamic load factor will likely be less than 2 due to the small volume and pancake-like geometry. To pressurize the hoses that are attached to the LDC, the 


\section{SNF-10272 REV. 2}

pressure pulse needs to travel back through a 1.5 inch nozzle to get to the inlet hose. This will slow down the rate of pressure increase in the hose. The discharge hose is not affected because of the torturous path back through the sludge filters and the 3 inch discharge pipe half way in the LDC (and well beneath the water). In addition, since the volume is so small, heat will be easily transferred to the top of the LDC and to the liquid. This will also decrease the pressure in the hoses. Therefore, there is some belief that the hoses will withstand burns from conditions in which the LDC headspace volume is small. To take credit for this, however will require a specific stress analysis.

\section{Reference:}

Roark's Formulas for Stress and Strain, 1989, McGraw-Hill Book Company, New York, New York.

Pressure Vessel Design and Analysis, 1967, MacMillan, London, England.

Calculation EN-3C-D126-04, 2002, K-East Basin Sludge Transport System-A-170 (Large Container): Structural Analysis, AVANTech Incorporated, Tacoma, Washington.

ASME, Section VIII, Division 1, "Design and Fabrication of Pressure Vessels," The American Society of Mechanical Engineers, New York, New York.

ASME, Section II, Part D, "Materials," The American Society of Mechanical Engineers, New York, New York.

SNF-9955, Rev 1, 2002, Safety-Basis Thermal Analysis for KE Basin Sludge Transport and Storage, Fluor Hanford, Inc., Richland, Washington.

HNF-SD-SNF-TI-015, Rev 9, 2002, SNF Project Technical Data Book, Volume 2, Sludge, Fluor Hanford, Inc., Richland, Washington. 
SNF-10272 REV. 2

This page is intentionally left blank 
SNF-10272 REV. 2

\section{APPENDIX D - GXQ CODE FILES}

Current Input File Name: kbasin1.IN

GXQ Version $4.0 \mathrm{~F}$

October 9, 2002

General Purpose Atmospheric Dispersion Code

Produced by Fluor Federal Services, Inc.

Users Guide documented in WHC-SD-GN-SWD-30002 Rev. 1.

validation documented in WHC-SD-GN-SWD-30003 Rev. 1.

Code Custodian is: Paul D. Rittmann, PhD CHP

Fluor Federal Services, Inc. E6-17

P.O. Box 1050

Richland, WA $99352-1050$

(509) $376-8715$

Run Date $=09 / 23 / 03$

Run Time $=14: 44: 18.85$

INPUT E,CHO:

K Basirs - 1-hr X/Q - 100 m - Inside Facility

C GXQ Version 4.0 Input File

c mode

1

$c$

C MODE CHOICE:

$C$ mode $=1$ then $X / Q$ based on Hanford site specific meteorology

$\mathrm{C}$ mode $=2$ then $\mathrm{X} / \mathrm{Q}$ based on atmospheric stability class and wind speed

$c$ mode $=3$ then $X / Q$ plot file is created

C LOGICAL CHOICES:

C ifox inorm icdf ichk isite ipop

$\begin{array}{llllll}T & F & F & F & T & F\end{array}$

ifox $=t$ then joint frequency used to compute frequency to exceed $x / Q$

$c=f$ then joint frequency used to compute annual average $\mathrm{X} / \mathrm{Q}$

inorm = then joint frequency data is normalized (as in GENII)

$=f$ then joint frequency data is un-normalized

icd.E $=t$ then cumulative distribution file created (CDF.OUT)

$=$ f then no cumulative distribution file created

ich $\mathrm{s}=\mathrm{t}$ then $\mathrm{X} / \mathrm{Q}$ parameter print option turned on

$=f$ then no parameter print

$C$ isize $=t$ then $X / Q$ based on joint frequency data for all 16 sectors

$=\mathrm{f}$ then $\mathrm{X} / Q$ based on joint frequency data of individual sectors

ipop $=t$ then $X / Q$ is population weighted

$=f$ then no population weighting

X/Q AND WIND SPEED ADJUSTMENT MODELS:

ipuff idep isrc iwind

$\begin{array}{llll}0 & 0 & 0 & 0\end{array}$

C DIEFCSION COEFFICIENT ADJUSTMENT MODELS:

C iwake ipm iflow ientr

2000

C EFFECTIVE RELEASE HEIGHT ADJUSTMENT MODELS: 


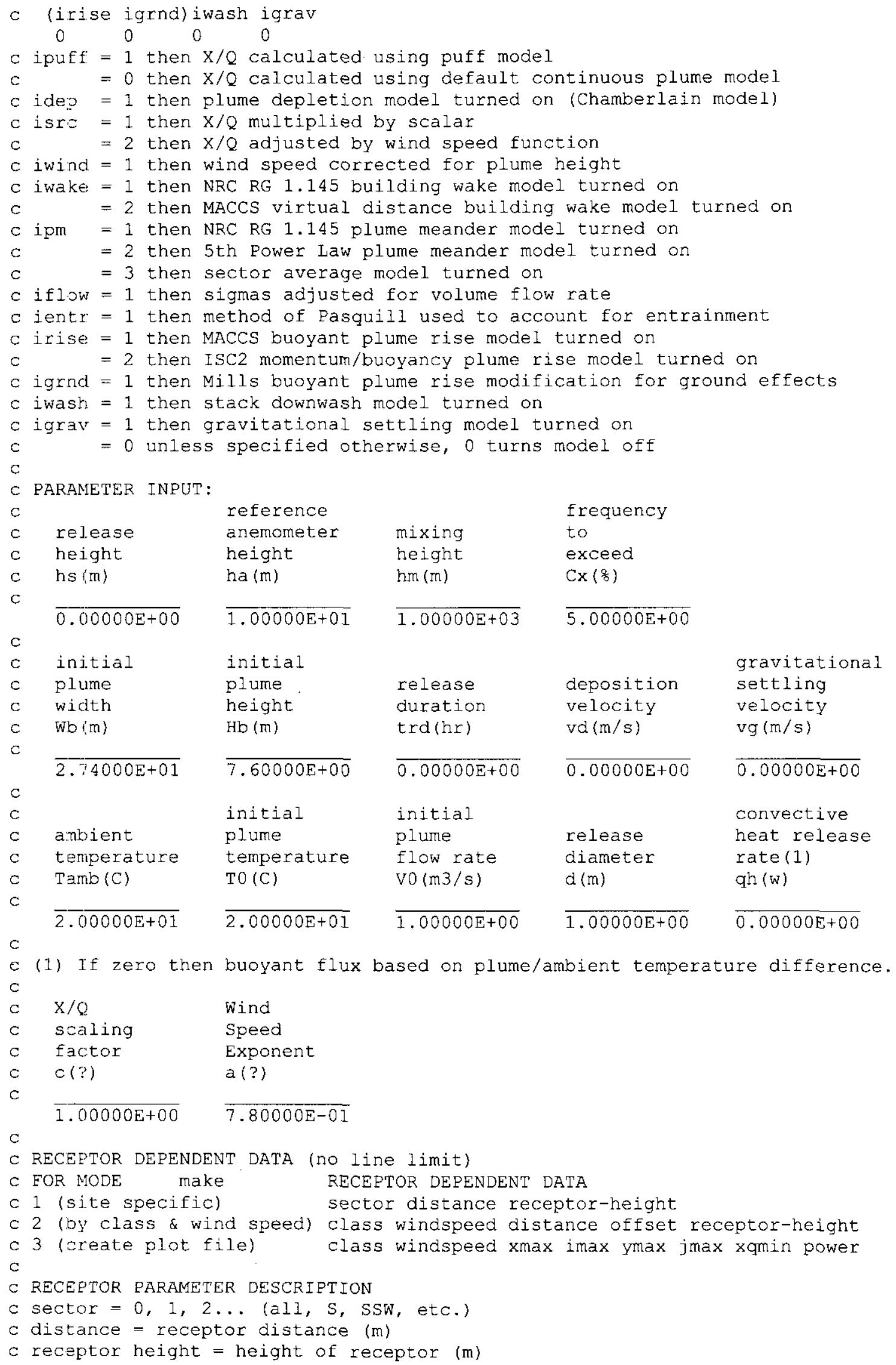




\section{SNF-10272 REV. 2}

c class $=1,2,3,4,5,6,7$ (P-G stability class A, B, C, D, E, F, G)

$c$ windspeed $=$ anemometer wind speed $(\mathrm{m} / \mathrm{s})$

$c$ offset $=$ offset from plume centerline (m)

c $x$ max $=$ maximum distance to plot or calculate to $(m)$

$c$ imax $=$ distance intervals

$c y \max =$ maximum offset to plot (m)

c jmax = offset intervals

c xqmin = minimum scaled $x / Q$ to calculate

c power = exponent in power function step size

MODE :

Site specific $X / Q$ calculated.

LOGICAL CHOICES:

Joint frequency used to calculate $\mathrm{X} / \mathrm{Q}$ based on frequency of exceedance.

No normalization of joint frequency.

$\mathrm{X} / \mathrm{Q}$ calculated for overall site.

MODELS SELECTED:

Time-integrated air concentration calculated (s/m3).

MACCS Virtual source building wake model selected.

WARNING/ERROR MESSAGES:

JOINT EREQUENCY DATA:

$100 \mathrm{~N}$ AREA - $10 \mathrm{M}$ - Pasquill A - G (1983 - 1991 Average)

Created $8 / 26 / 92 \mathrm{KR}$

K Basins - 1-hr X/Q - 100 m - Inside Eacility

\begin{tabular}{|c|c|c|c|c|c|c|c|c|}
\hline & & & & & $\begin{array}{c}\text { TOTAL } \\
\text { POPULATION }\end{array}$ & $\begin{array}{l}\text { AVERAGE } \\
\text { INDIVIDUAL }\end{array}$ & & \\
\hline & & RECEPT & SECT. & & SCALED & SCALED & ATM. & WIND \\
\hline SECTOR & $\begin{array}{l}\text { DISTANCE } \\
(\mathrm{m})\end{array}$ & $\begin{array}{l}\text { HEIGHT } \\
(\mathrm{m})\end{array}$ & $\begin{array}{c}\text { FREQ. } \\
\left(\frac{O}{\delta}\right)\end{array}$ & POPULATION & $\begin{array}{l}X / Q \\
(s / m 3)\end{array}$ & $\begin{array}{l}X / Q \\
(s / m 3)\end{array}$ & $\begin{array}{l}\text { STAB. } \\
\text { CLASS }\end{array}$ & $\begin{array}{l}\text { SPEED } \\
(\mathrm{m} / \mathrm{s})\end{array}$ \\
\hline LL & 100 & & 99.80 & & $8.07 E-03$ & $8.07 \mathrm{E}-03$ & $\bar{G}$ & 0.89 \\
\hline
\end{tabular}

Current Input File Name: kbasin2.IN 
SNF-10272 REV. 2

GXQ Version $4.0 \mathrm{~F}$

October 9, 2002

General Purpose Atmospheric Dispersion Code Produced by Fluor Federal Services, Inc.

Users Guide documented in WHC-SD-GN-SWD-30002 Rev. 1. Validation documented in WHC-SD-GN-SWD-30003 Rev. 1 . Code Custodian is: Paul D. Rittmann, PhD CHP

Fluor Federal Services, Inc. E6-17

P.O. Box 1050

Richland, WA 99352-1050

(509) 376-8715

Run Date $=09 / 19 / 03$

Run Time $=10: 07: 37.18$

INPUT ECHO:

K Basins - 1-hr X/Q - $100 \mathrm{~m}$ - Outside Facility

c GXQ Version 4.0 Input File

c mode

1

$\mathrm{C}$

C MODE CHOICE:

$c$ mode $=1$ then $X / Q$ based on Hanford site specific meteorology

$C$ mode $=2$ then $X / Q$ based on atmospheric stability class and wind speed

$c$ mode $=3$ then $X / Q$ plot file is created

$c$

c LOGICAL CHOICES:

C ifox inorm icdf ichk isite ipop

$\begin{array}{llllll}T & F & F & F & T & F\end{array}$

$\mathrm{c}$ ifox $=t$ then joint frequency used to compute frequency to exceed $X / Q$

$c=f$ then joint frequency used to compute annual average $\mathrm{X} / \mathrm{Q}$

$c$ inorm $=t$ then joint frequency data is normalized (as in GENII)

$\mathrm{c}=\mathrm{f}$ then joint frequency data is un-normalized

$c$ icdf $=t$ then cumulative distribution file created (CDF.OUT)

c $\quad \mathrm{E}$ then no cumulative distribution file created

ichk $=\mathrm{t}$ then $\mathrm{X} / \mathrm{Q}$ parameter print option turned on

$\mathrm{C}=\mathrm{f}$ then no parameter print

$c$ isite $=t$ then $X / Q$ based on joint frequency data for all 16 sectors

$\mathrm{c}=\mathrm{f}$ then $\mathrm{X} / \mathrm{Q}$ based on joint frequency data of individual sectors

$c$ ipop $=t$ then $\mathrm{X} / \mathrm{Q}$ is population weighted

$\mathrm{C}=\mathrm{f}$ then no population weighting

$c$

$C X / Q$ AND WIND SPEED ADJUSTMENT MODELS:

c iouff idep isrc iwind

$\begin{array}{llll}0 & 0 & 0 & 0\end{array}$

C DIFEUSION COEFFICIENT ADJUSTMENT MODELS:

C iwake ipm iflow ientr

2000

C EEFECTIVE RELEASE HEIGHT ADJUSTMENT MODELS:

C (irise igrnd) iwash igrav

00000

$c$ ipuff $=1$ then $x / Q$ calculated using puff model

$\mathrm{C}=0$ then $\mathrm{X} / \mathrm{Q}$ calculated using default continuous plume model

c idep $=1$ then plume depletion model turned on (Chamberlain model) 
SNF-10272 REV. 2

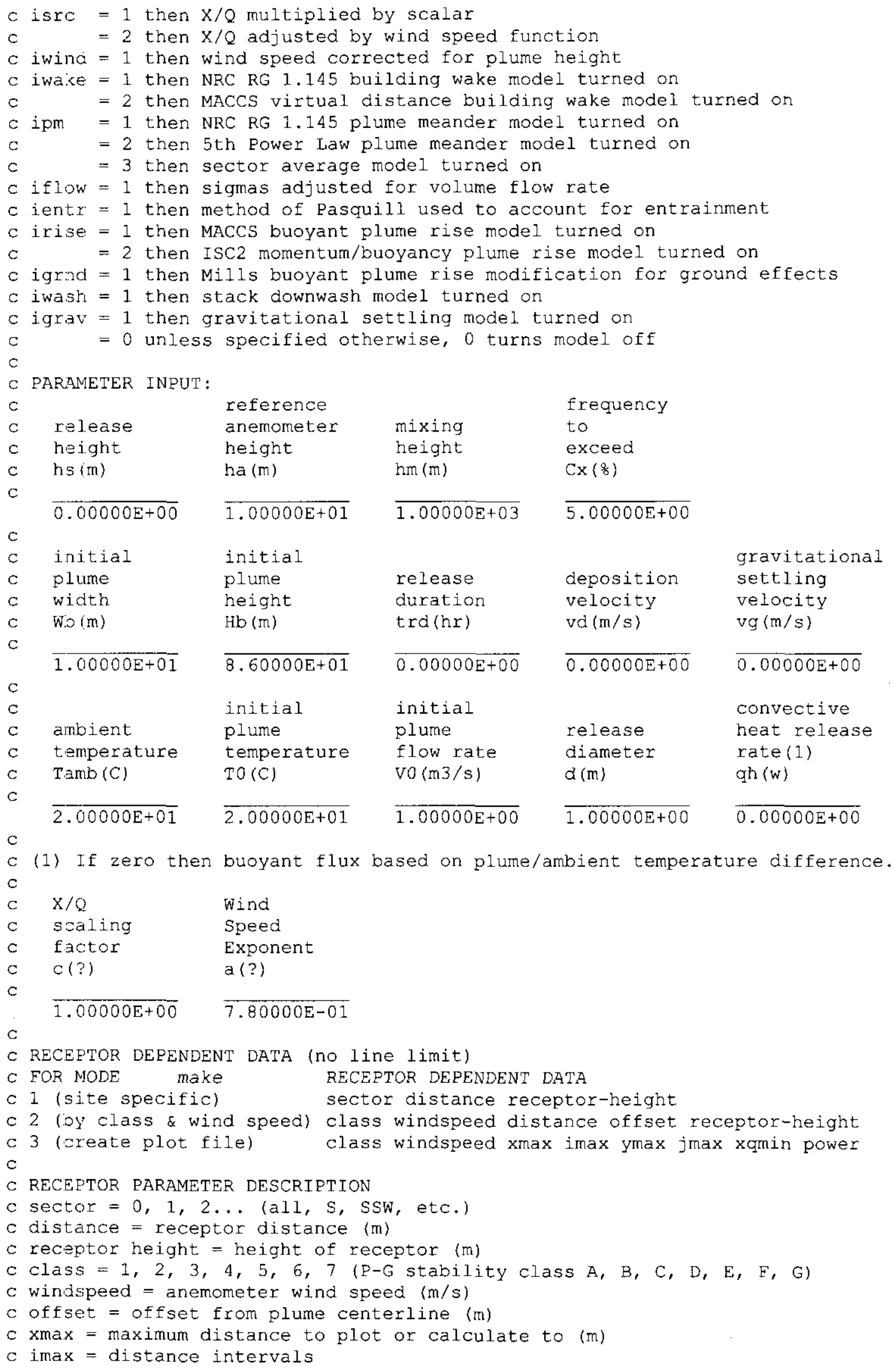




\section{SNF-10272 REV. 2}

c ymax $=$ maximum offset to plot $(m)$

c jmax = offset intervals

$c$ xqmir = minimum scaled $\mathrm{X} / \mathrm{Q}$ to calculate

$c$ power $=$ exponent in power function step size

MODE :

Site specific $\mathrm{X} / \mathrm{Q}$ calculated.

LOGICAI, CHOICES:

Joint frequency used to calculate $X / Q$ based on frequency of exceedance.

No normalization of joint frequency.

$\mathrm{X} / \mathrm{Q}$ calculated for overall site.

MODELS SELECTED:

Time-irtegrated air concentration calculated ( $\mathrm{s} / \mathrm{m} 3$ ).

MACCS Virtual source building wake model selected.

WARNING/ERROR MESSAGES:

JOINT EREQUENCY DATA:

100 N AREA - 10 M - Pasquil1 A - G (1983 - 1991 Average)

Created $8 / 26 / 92 \mathrm{KR}$

K Basirs - 1-hr X/Q - $100 \mathrm{~m}$ - Outside Facility

\begin{tabular}{|c|c|c|c|c|c|c|c|c|}
\hline & & & & & $\begin{array}{l}\text { TOTAL } \\
\text { POPULATION }\end{array}$ & $\begin{array}{l}\text { AVERAGE } \\
\text { INDIVIDUAL }\end{array}$ & & \\
\hline & & RECEPT & SECT. & & SCALED & SCALED & ATM. & WIND \\
\hline ECTOR & $\begin{array}{l}\text { DISTANCE } \\
\text { (m) }\end{array}$ & $\begin{array}{l}\text { HEIGHT } \\
(\mathrm{m})\end{array}$ & $\begin{array}{l}\text { FREQ. } \\
\left(\frac{q}{b}\right)\end{array}$ & POPULATION & $\begin{array}{l}X / Q \\
(\mathrm{~s} / \mathrm{m} 3)\end{array}$ & $\begin{array}{l}X / Q \\
(\mathrm{~s} / \mathrm{m} 3)\end{array}$ & $\begin{array}{l}\text { STAB, } \\
\text { CLASS }\end{array}$ & $\begin{array}{l}\text { SPEED } \\
(\mathrm{m} / \mathrm{s})\end{array}$ \\
\hline & & & 99.80 & & $1.57 \mathrm{E}-03$ & $1.57 \mathrm{E}-03$ & $\bar{G}$ & 0.89 \\
\hline
\end{tabular}

Current. Input File Name: kbasin1b.IN 
SNF-10272 REV. 2

GXQ Version $4.0 \mathrm{~F}$

October 9, 2002

General Purpose Atmospheric Dispersion Code Produced by Fluor Federal Services, Inc.

Users Guide documented in WHC-SD-GN-SWD-30002 Rev. 1.

Validation documented in WHC-SD-GN-SWD-30003 Rev. 1.

Code Custodian is: Paul D. Rittmann, PhD CHP

Fluor Federal Services, Inc. E6-17

P.O. Box 1050

Richland, WA 99352-1050

(509) $376-8715$

Run Date $=09 / 23 / 03$

Run Time $=14: 45: 48.92$

INPUT ECHO:

K Basins - 1-hr X/Q - receptors $>100 \mathrm{~m}$ with deposition - Inside Facility

C GXQ Version 4.0 Input File

c mode

1

$\mathrm{C}$

C MOD更 CHOICE:

$c$ mode $=1$ then $X / Q$ based on Hanford site specific meteorology

$c$ mode $=2$ then $X / Q$ based on atmospheric stability class and wind speed

$c$ mode $=3$ then $X / Q$ plot file is created

C LOGICAL CHOICES:

C ifox inorm icdf ichk isite ipop

$\begin{array}{llllll}T & F & F & F & F & F\end{array}$

$c$ ifox $=t$ then joint frequency used to compute frequency to exceed $\mathrm{X} / \mathrm{Q}$

$\mathrm{c}=\mathrm{f}$ then joint frequency used to compute annual average $\mathrm{X} / \mathrm{Q}$

$c$ inorm $=t$ then joint frequency data is normalized (as in GENII)

$c=f$ then joint frequency data is un-normalized

$c$ icdf $=t$ then cumulative distribution file created (CDF.OUT)

c $\quad f$ then no cumulative distribution file created

$i c h k=t$ then $x / Q$ parameter print option turned on

C $\quad f$ then no parameter print

isite $=t$ then $X / Q$ based on joint frequency data for all 16 sectors

$\mathrm{c} \quad=\mathrm{f}$ then $\mathrm{X} / \mathrm{Q}$ based on joint frequency data of individual sectors

$c$ ipop $=t$ then $X / Q$ is population weighted

C X/Q AND WIND SPEED ADJUSTMENT MODELS:

C ipuff idep isrc iwind

$$
0 \quad 1100
$$

C DIFEUSION COEFEICIENT ADJUSTMENT MODELS:

C iwake ipm iflow ientr

$$
2000
$$

C EEFECTIVE RELEASE HEIGHT ADJUSTMENT MODELS:

C (irise igrnd) iwash igrav

00000

$C$ ipuff $=1$ then $X / Q$ calculated using puff model

$c=0$ then $X / Q$ calculated using default continuous plume model

$c$ ide? $=1$ then plume depletion model turned on (Chamberlain model) 


\section{SNF-10272 REV. 2}

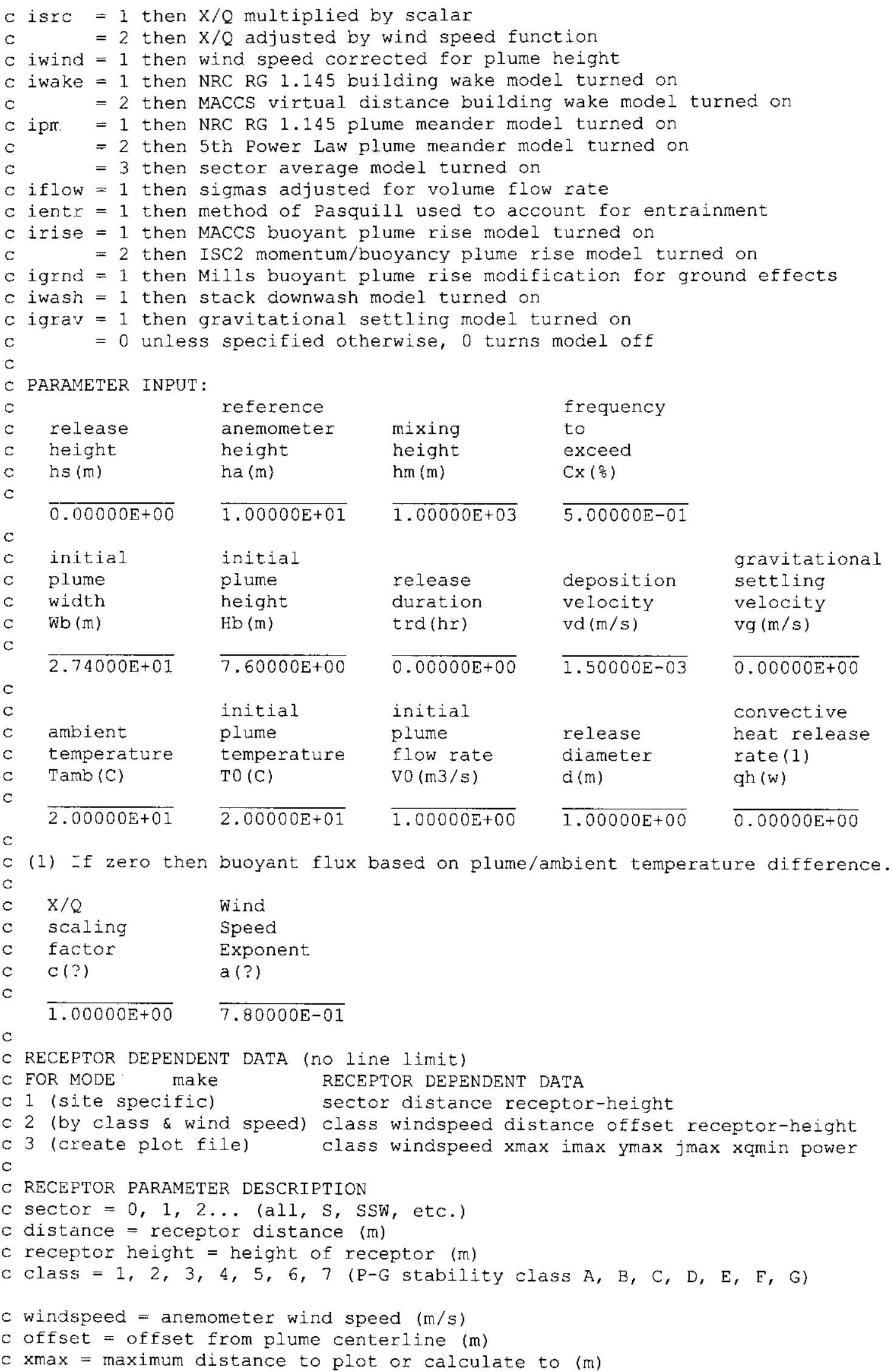


SNF-10272 REV. 2

c $i \max =$ distance intervals

c $y \max =$ maximum offset to plot $(\mathrm{m})$

$c$ jmax $=$ offset intervals

c $x$ min $=$ minimum scaled $X / Q$ to calculate

$c$ power $=$ exponent in power function step size

MODE :

Site specific $X / Q$ calculated.

LOGICAI, CHOICES:

Joint frequency used to calculate $X / Q$ based on frequency of exceedance.

No normalization of joint frequency.

$\mathrm{X} / \mathrm{Q}$ calculated for single sector.

MODELS SELECTED:

Time-integrated air concentration calculated (s/m3).

MACCS Virtual source building wake model selected.

Source depletion model selected.

WARNING/ERROR MESSAGES:

JOINT FREQUENCY DATA:

$100 \mathrm{~N}$ AREA - $10 \mathrm{M}$ - Pasquill A - G (1983 - 1991 Average)

Created $8 / 26 / 92 \mathrm{KR}$

K Basins - 1-hr X/Q - receptors $>100$ m with deposition - Inside Facility

\begin{tabular}{|c|c|c|c|c|c|c|c|c|}
\hline & & & & & $\begin{array}{c}\text { TOTAL } \\
\text { POPULATION }\end{array}$ & $\begin{array}{l}\text { AVERAGE } \\
\text { INDIVIDUAL }\end{array}$ & & \\
\hline & & RECEPT & SECT. & & SCALED & SCALED & ATM. & WIND \\
\hline SECTOR & $\begin{array}{l}\text { DISTANCE } \\
(\mathrm{m})\end{array}$ & $\begin{array}{l}\text { HEIGHT } \\
\text { (m) }\end{array}$ & $\begin{array}{l}\text { FREQ. } \\
\qquad\left(\frac{0}{\partial}\right)\end{array}$ & POPULATION. & $\begin{array}{l}X / Q \\
(s / m 3)\end{array}$ & $\begin{array}{l}X / Q \\
(s / m 3)\end{array}$ & $\begin{array}{l}\text { STAB. } \\
\text { CLASS }\end{array}$ & $\begin{array}{l}\text { SPEED } \\
(\mathrm{m} / \mathrm{s})\end{array}$ \\
\hline & 520 & 0 & 7.54 & 1 & 1.71 & & $\mathrm{~F}$ & 0.89 \\
\hline ISE & 3750 & 0 & 10.16 & 1 & $9.91 E-05$ & $9.91 E-05$ & $F$ & 0.89 \\
\hline & 10070 & 0 & 7.54 & & & $1.69 E-05$ & & 2.65 \\
\hline
\end{tabular}


SNF-10272 REV. 2

Current Input File Name: kbasin2b. IN

GXQ Version $4.0 \mathrm{~F}$

october 9, 2002

General Purpose Atmospheric Dispersion Code

Produced by Fluor Federal Services, Inc.

Users Guide documented in WHC-SD-GN-SWD-30002 Rev. 1.

Validation documented in WHC-SD-GN-SWD-30003 Rev. 1.

Code Custodian is: Paul D. Rittmann, PhD CHP

Fluor Federal Services, Inc. E6-17

P.O. Box 1050

Richland, WA 99352-1050

(509) $376-8715$

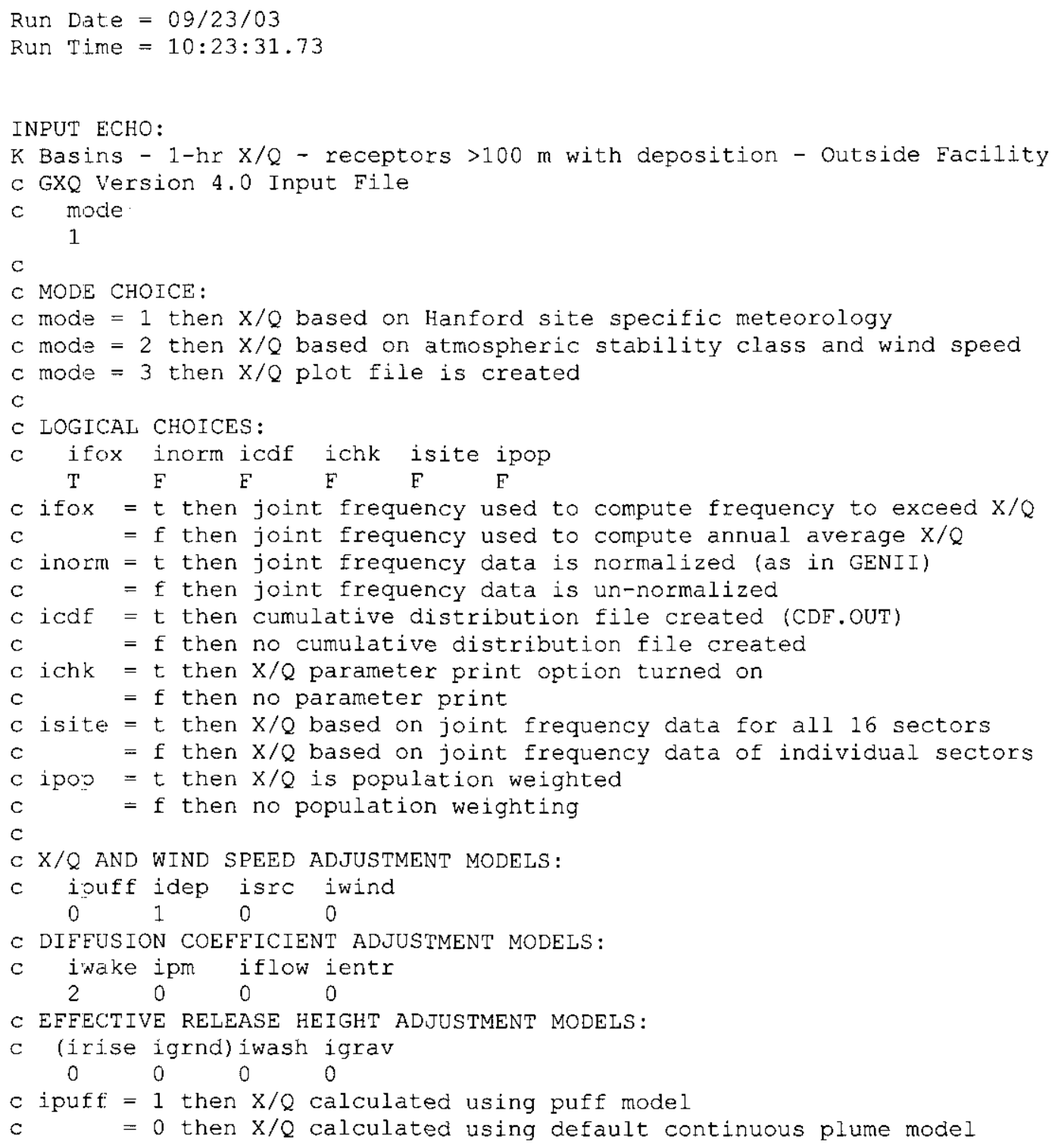




\section{SNF-10272 REV. 2}

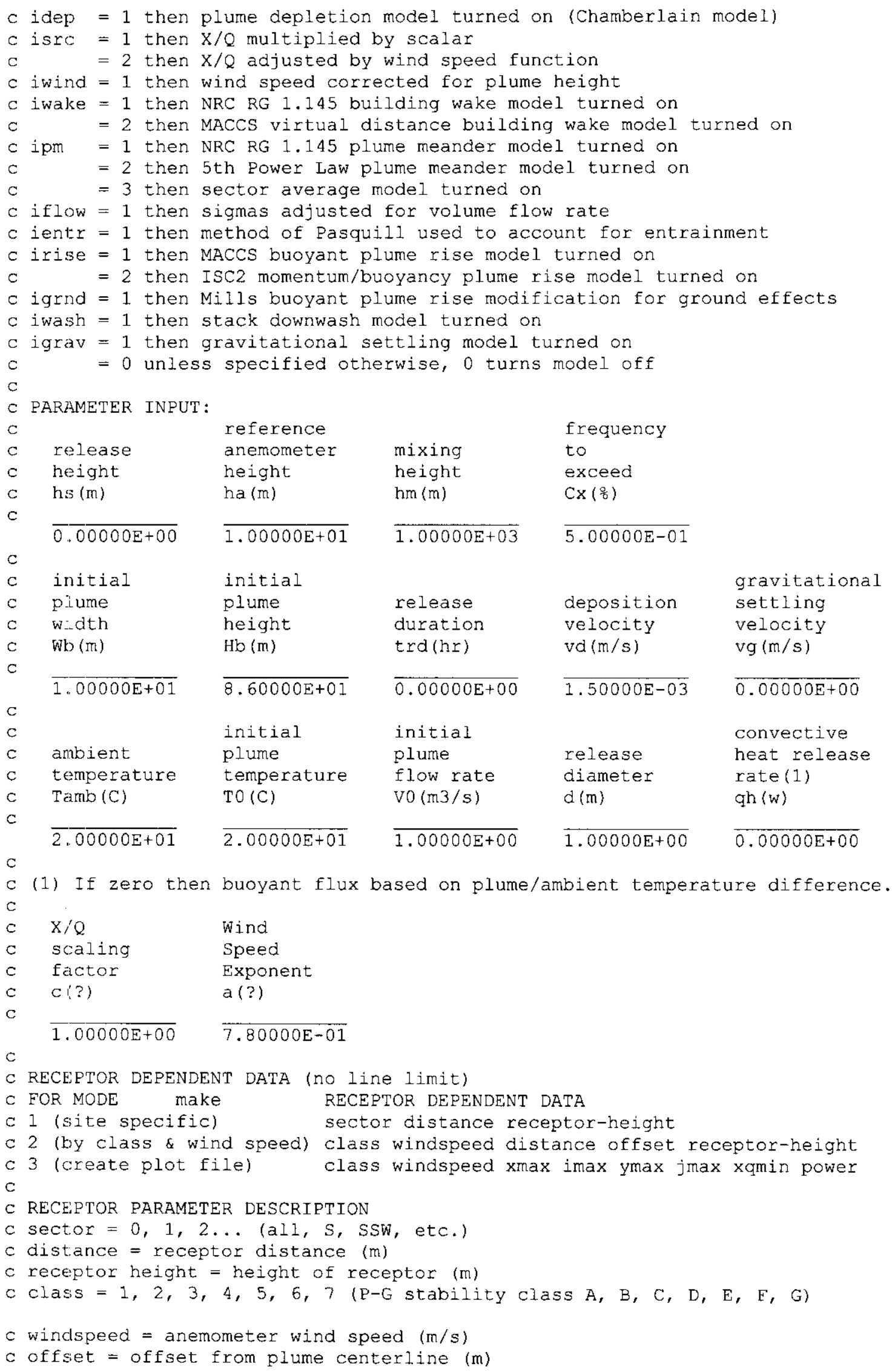




\section{SNF-10272 REV. 2}

$c \max =$ maximum distance to plot or calculate to (m)

$c$ imax $=$ distance intervals

$c y \max =$ maximum offset to plot $(\mathrm{m})$

$c$ jmax $=$ offset intervals

c $x q m i n=$ minimum scaled $X / Q$ to calculate

$c$ power $=$ exponent in power function step size

MODE:

Site specific $X / Q$ calculated.

LOGICAI, CHOICES:

Joint frequency used to calculate $\mathrm{X} / \mathrm{Q}$ based on frequency of exceedance.

No normalization of joint frequency.

$X / Q$ calculated for single sector.

MODELS SELECTED:

Time-iritegrated air concentration calculated (s/m3).

MACCS Virtual source building wake model selected.

Source depletion model selected.

WARNING/ERROR MESSAGES:

JOINT EREQUENCY DATA:

100 N AREA - 10 M - Pasquill A - G (1983 - 1991 Average)

Created $8 / 26 / 92 \mathrm{KR}$

K Basirs - 1-hr $X / Q$ - receptors $>100 \mathrm{~m}$ with deposition - Outside Facility

TOTAL AVERAGE

POPULATION INDIVIDUAL

\begin{tabular}{|c|c|c|c|c|c|c|c|c|}
\hline SECTOR & $\begin{array}{l}\text { DISTANCE } \\
(\mathrm{m})\end{array}$ & $\begin{array}{c}\text { RECEPT } \\
\text { HEIGHT } \\
\text { (m) }\end{array}$ & $\begin{array}{c}\text { SECT. } \\
\text { FREQ. } \\
\left(\frac{\circ}{6}\right)\end{array}$ & POPULATION & $\begin{array}{c}\text { SCALED } \\
X / Q \\
(\mathrm{~s} / \mathrm{m} 3)\end{array}$ & $\begin{array}{c}\text { SCALED } \\
X / Q \\
(\mathrm{~s} / \mathrm{m} 3)\end{array}$ & $\begin{array}{l}\text { ATM. } \\
\text { STAB. } \\
\text { CLASS }\end{array}$ & $\begin{array}{l}\text { WIND } \\
\text { SPEED } \\
(\mathrm{m} / \mathrm{s})\end{array}$ \\
\hline $\bar{W}$ & 520 & 0 & 7.54 & $\overline{1}$ & $4.74 \mathrm{E}-04$ & $4.74 \mathrm{E}-04$ & $\bar{F}$ & 0.89 \\
\hline ESE & 3750 & 0 & 10.16 & 1 & $7.17 \mathrm{E}-05$ & $7.17 \mathrm{E}-05$ & $\mathrm{~F}$ & 0.89 \\
\hline$w$ & 10070 & 0 & 7.54 & 1 & $2.28 E-05$ & $2.28 \mathrm{E}-05$ & $\mathrm{~F}$ & 0.89 \\
\hline
\end{tabular}


SNF-10272 REV. 2

\section{APPENDIX E - MICROSHIELD OUTPUT}

Appendix E contains the Microshield ${ }^{1}$ computer code output supporting the results contained in Section 3.4.13. Twelve files are provided. The first three are for the unshielded LDC. The remaining nine are for the plugged fill line.

' Grove Engineering, 1988, Microshield Version 3, Grove Engineering, Inc., Rockville, Maryland. 
CONTAINER MODEL

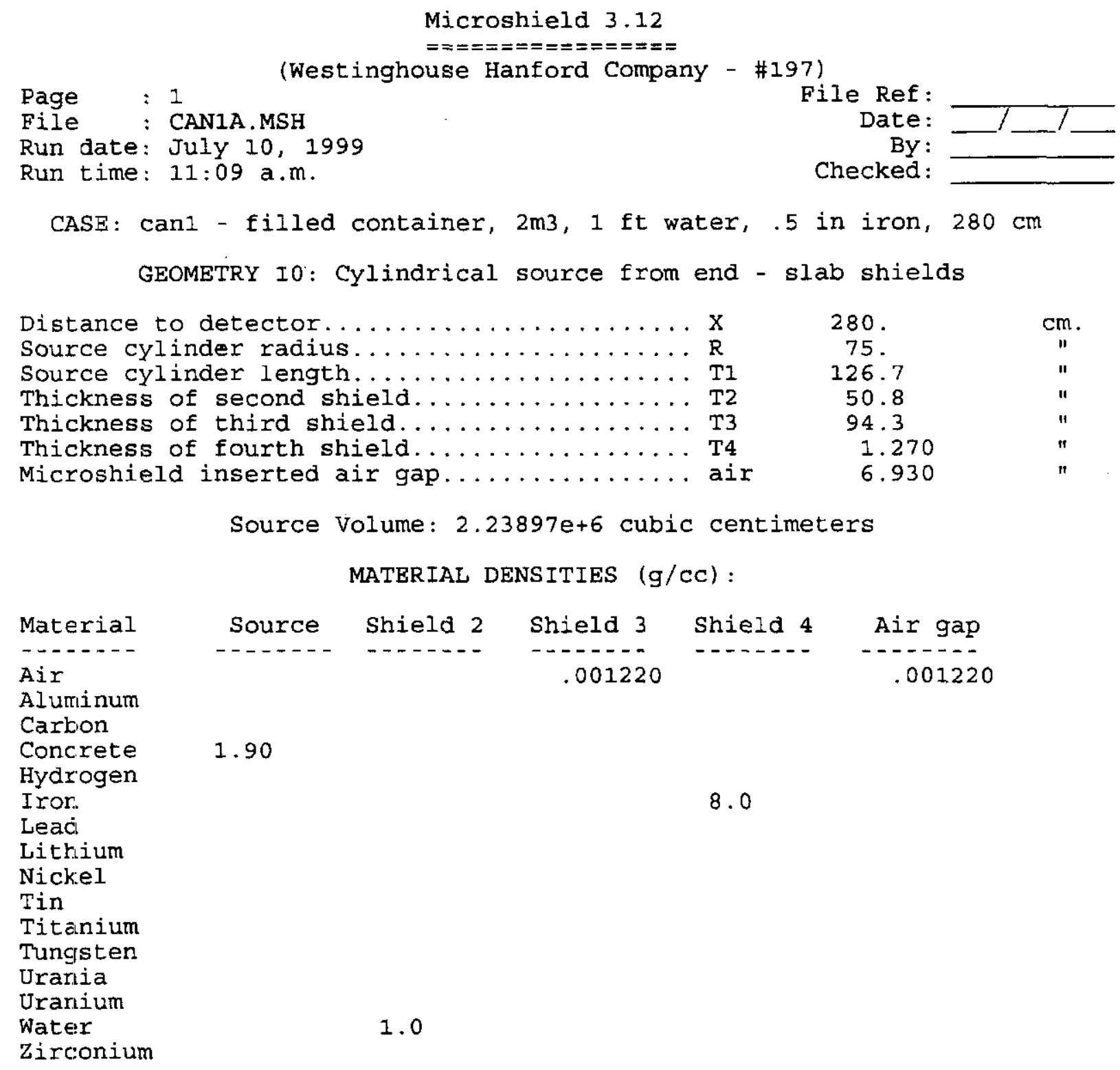


Page 2

File: CAN1A.MSH

CASE: canl - filled container, $2 \mathrm{~m} 3,1 \mathrm{ft}$ water, .5 in iron, $280 \mathrm{~cm}$

BUILDUP FACTOR: based on GP method.
Using the characteristics of the materials in shield 1 .

INTEGRATION PARAMETERS:

Number of angle segments (Npsi) ........... 51

Number of radial segments (Nradius).......... 51

SOURCE NUCLIDES :

\begin{tabular}{|c|c|c|c|c|c|}
\hline Nuclide & Curies & Nuclide & Curies & Nuclide & Curies \\
\hline $\mathrm{Ba}-137 \mathrm{~m}$ & $1.0000 e+00$ & Co-60 & $0.0000 e+00$ & $\mathrm{Cs}-137$ & $1.0000 \mathrm{e}+00$ \\
\hline
\end{tabular}

RESULTS :

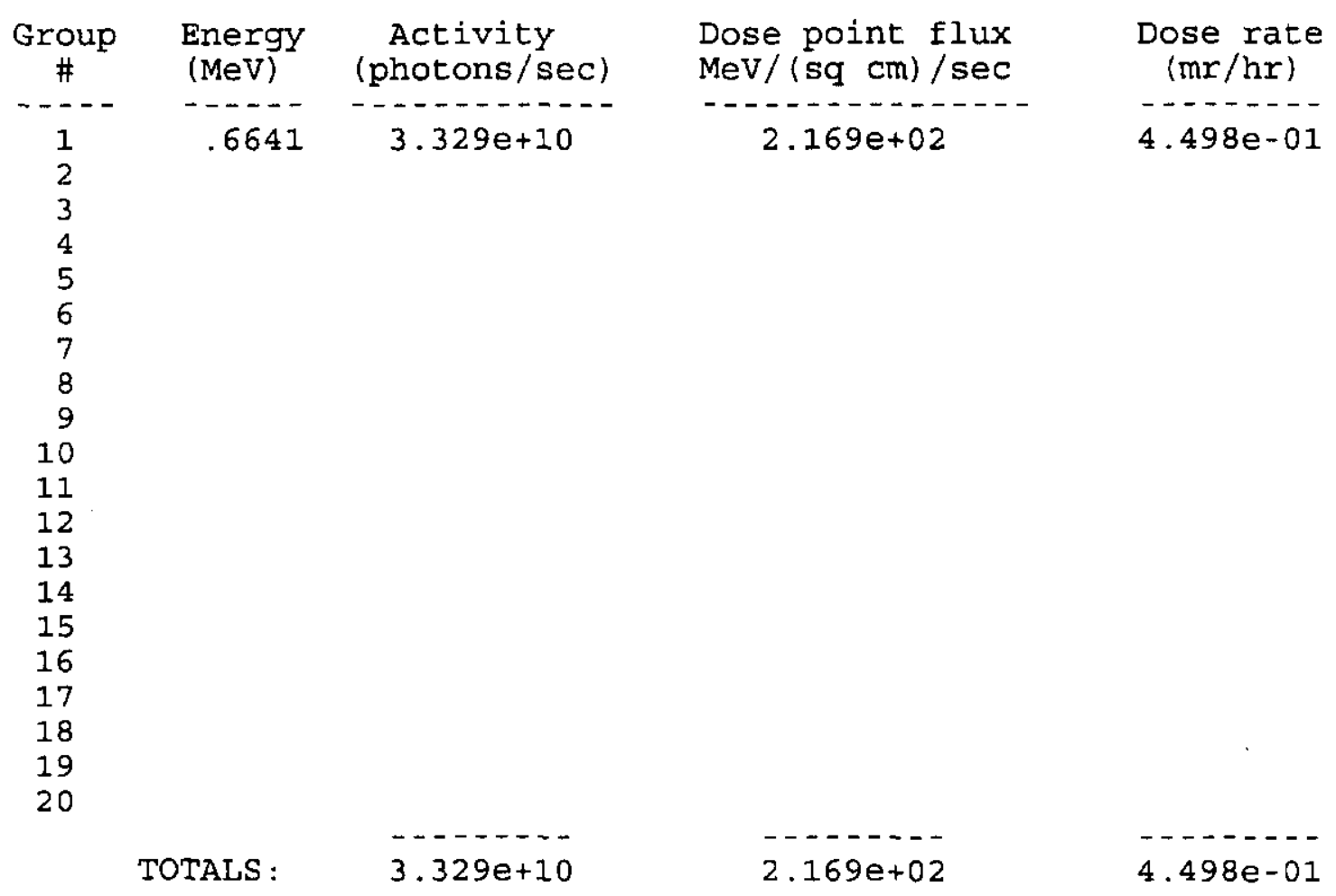


Microshield 3.12

$== \pm===========$

(Westinghouse Hanford Company - \#197)

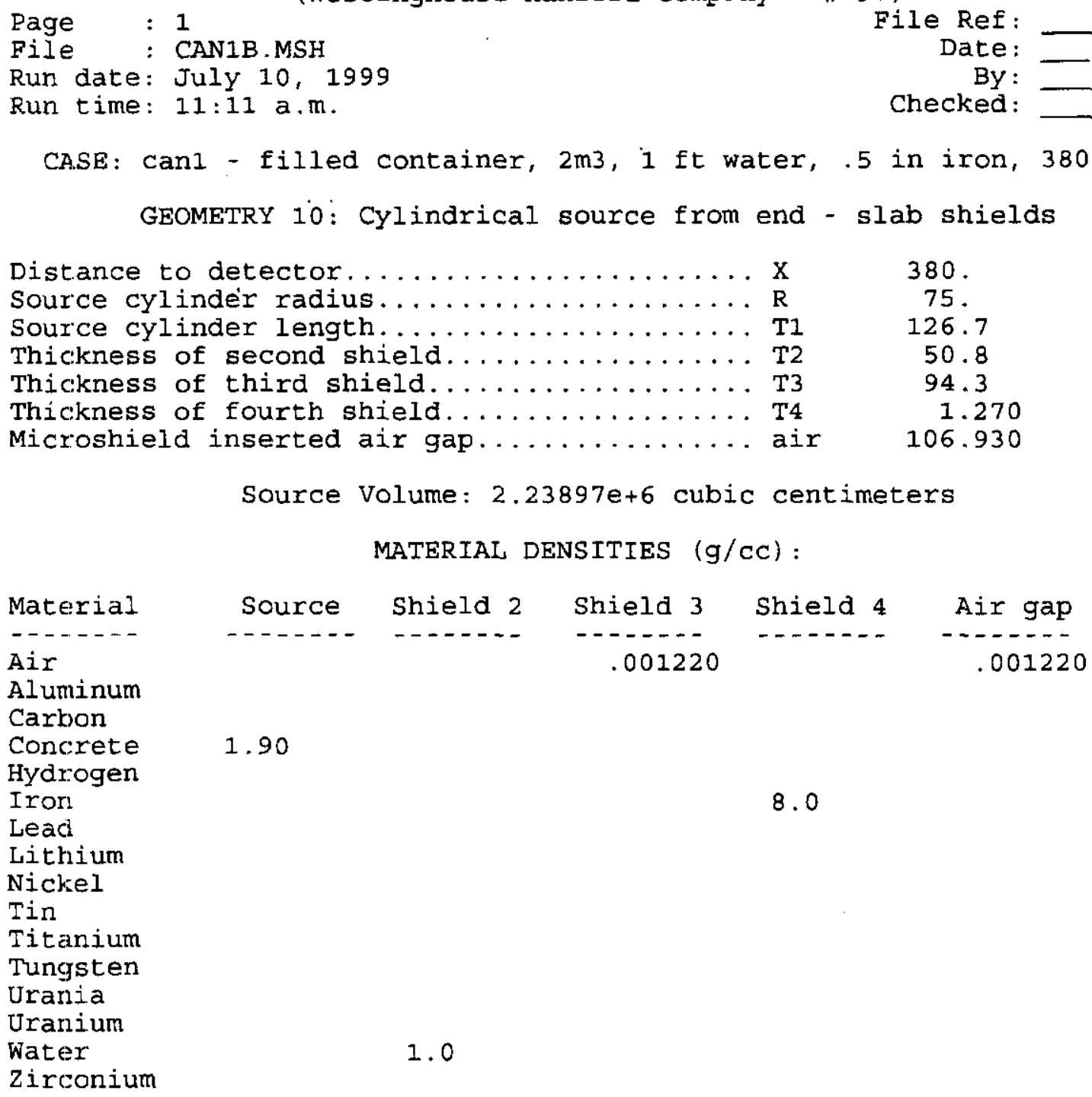


CASE: can 1 - filled container, $2 \mathrm{~m} 3,1$ ft water, .5 in iron, $380 \mathrm{~cm}$

BUILDUP FACTOR: based on GP method. Using the characteristics of the materials in shield 1 .

INTEGRATION PARAMETERS :

Number of angle segments (Npsi) ........... 51

Number of radial segments (Nradius) .......... 51

\begin{tabular}{llllll} 
& \multicolumn{5}{c}{ SOURCE NUCLIDES: } \\
Nuclide & Curies & Nuclide & Curies & Nuclide & Curies \\
\hdashline Ba-137m & $1.0000 e+00$ & Co-60 & $0.0000 e+00$ & Cs -137 & $1.0000 \mathrm{e}+00$ \\
$\mathrm{~N}-16$ & $0.0000 \mathrm{e}+00$ & & & &
\end{tabular}

RESULTS :

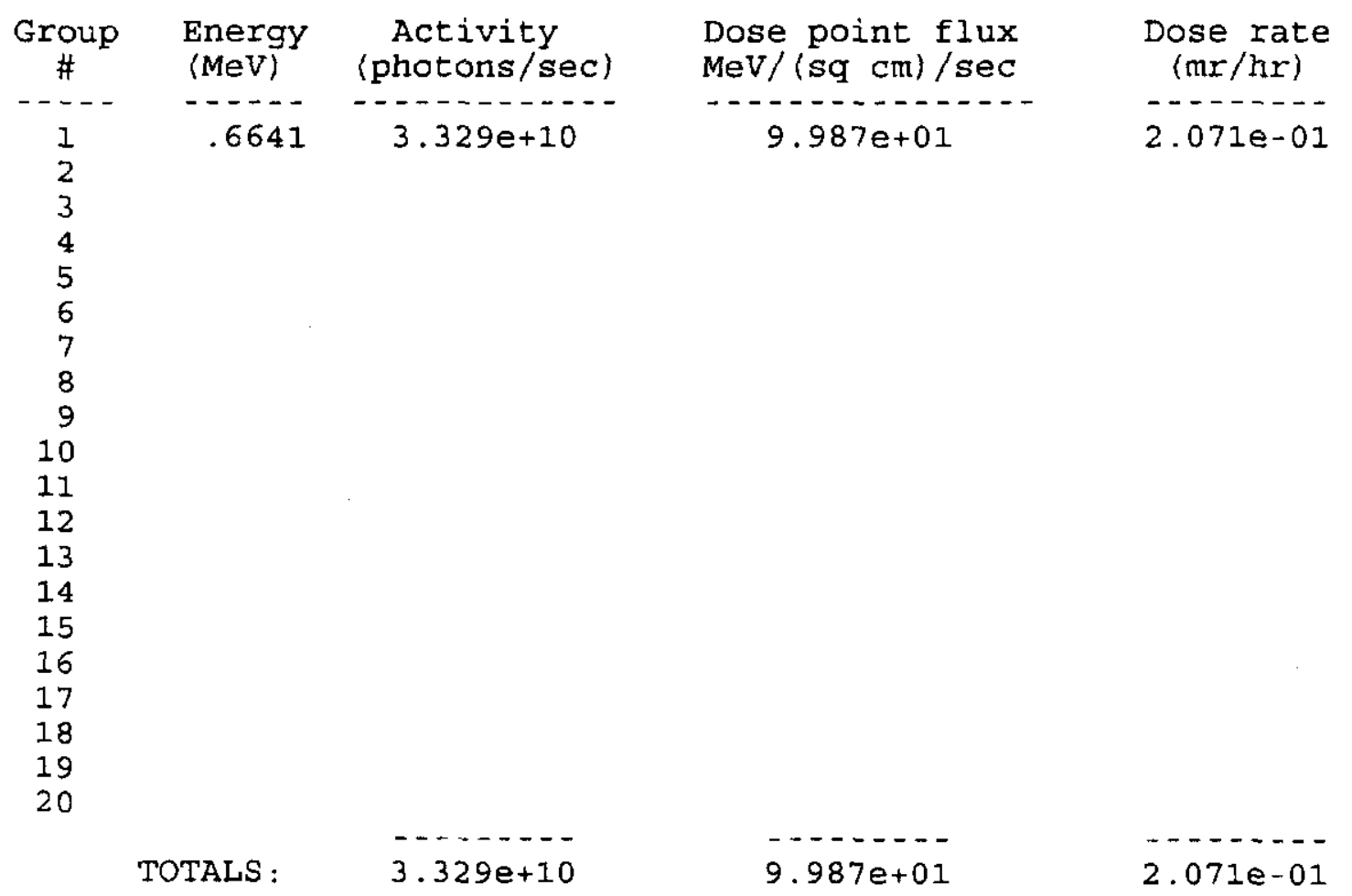


Microshield 3.12

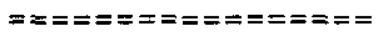
(Westinghouse Hanford Company - \#197)

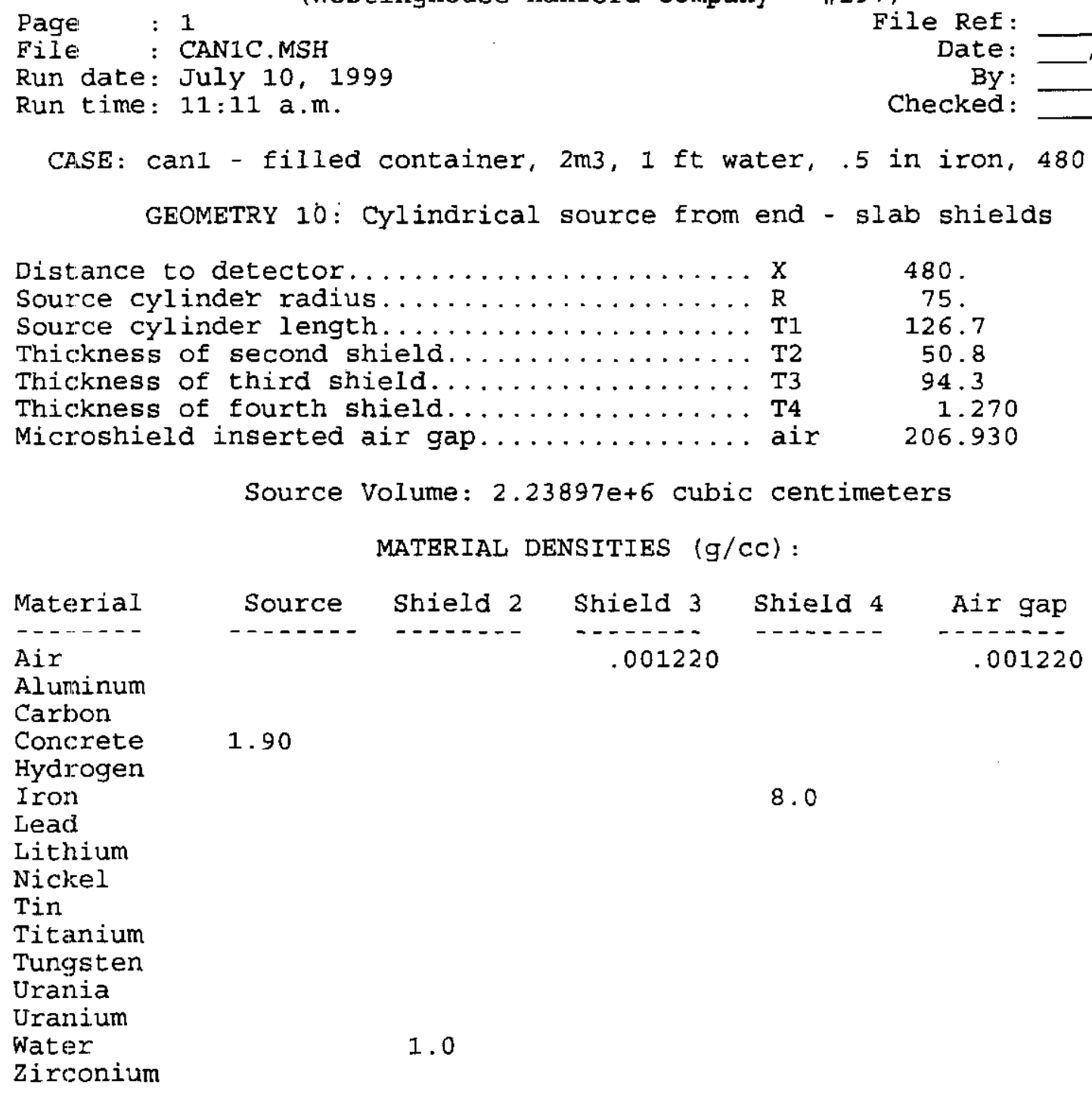


CASE: can1 - filled container, $2 \mathrm{~m} 3,1$ ft water, .5 in iron, $480 \mathrm{~cm}$

BUILDUP FACTOR: based on GP method. Using the characteristics of the materials in shield 1 .

\section{INTEGRATION PARAMETERS :}

Number of angle segments (Npsi) ........... 51

Number of radial segments (Nradius).......... 51

\begin{tabular}{llllll} 
& \multicolumn{7}{c}{ SOURCE NUCLIDES : } \\
Nuclide & Curies & Nuclide & Curies & Nuclide & Curies \\
\hdashline Ba-137m & $1.0000 \mathrm{e}+00$ & Co-60 & $0.0000 \mathrm{e}+00$ & Cs -137 & $1.0000 \mathrm{e}+00$ \\
$\mathrm{~N}-16$ & $0.0000 \mathrm{e}+00$ & & & &
\end{tabular}

RESULTS :

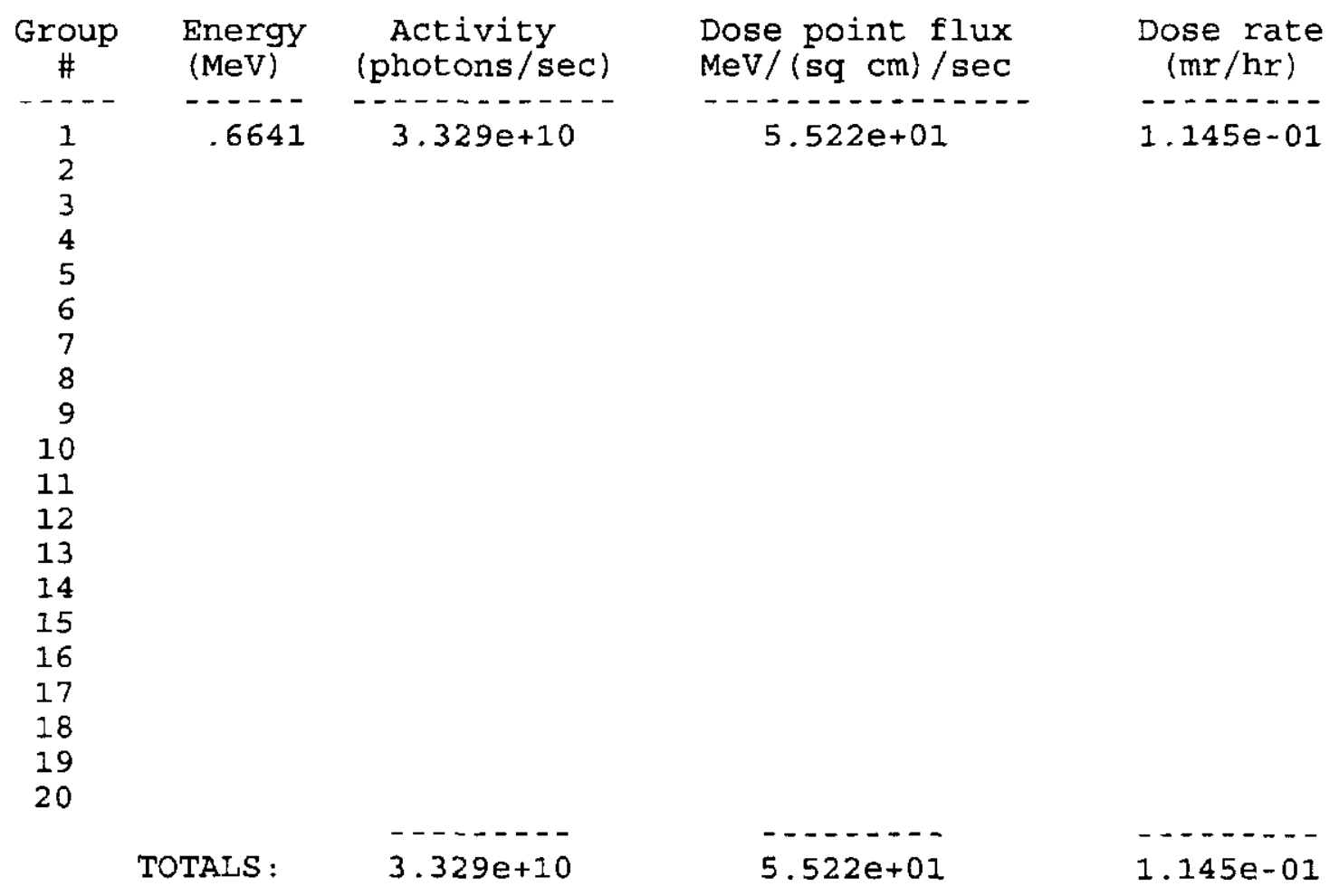




\section{PIPE MODEL}

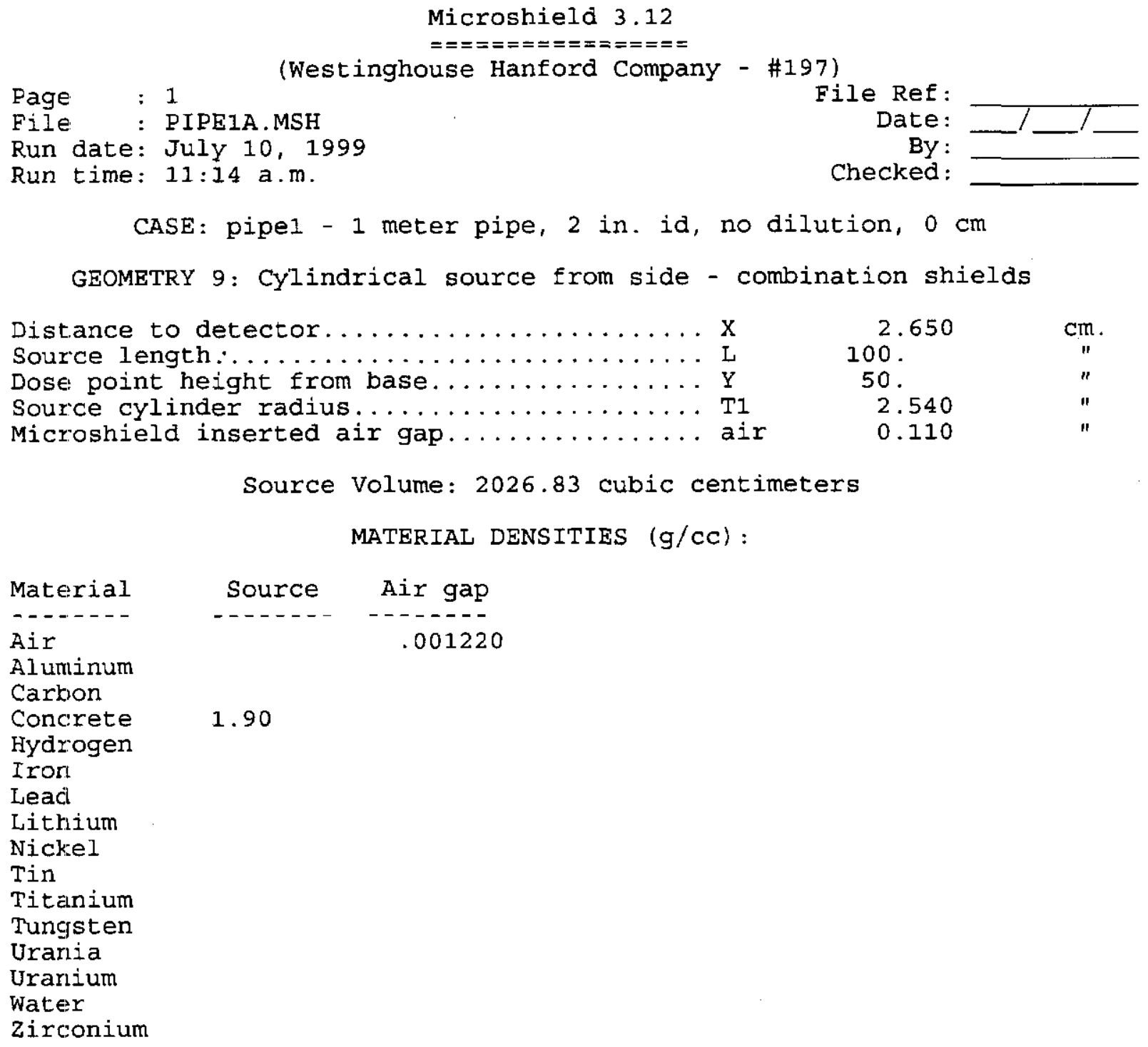


CASE: pipel - 1 meter pipe, 2 in. id, no dilution, $0 \mathrm{~cm}$

File: PIPE1A.MSH

BUILDUP FACTOR: based on GP method.

Using the characteristics of the materials in shield 1 .

\section{INTEGRATION PARAMETERS :}

Number of Iateral angle segments (Ntheta)..... 5 I

Number of azimuthal angle segments (Npsi)..... 51

Number of radial segments (Nradius).......... 51

\section{SOURCE NUCLIDES :}

$\begin{array}{llllll}\text { Nuclide } & \text { Curies } & \text { Nuclide } & \text { Curies } & \text { Nuclide } & \text { Curies } \\ -\cdots \mathrm{Ba}-137 \mathrm{~m} & 1.0000 \mathrm{e}+00 & \mathrm{C}-60 & 0.0000 \mathrm{e}+00 & \mathrm{Cs}-137 & 1.0000 \mathrm{e}+00 \\ \mathrm{~N}-16 & 0.0000 \mathrm{e}+00 & & & & \end{array}$

RESULTS :

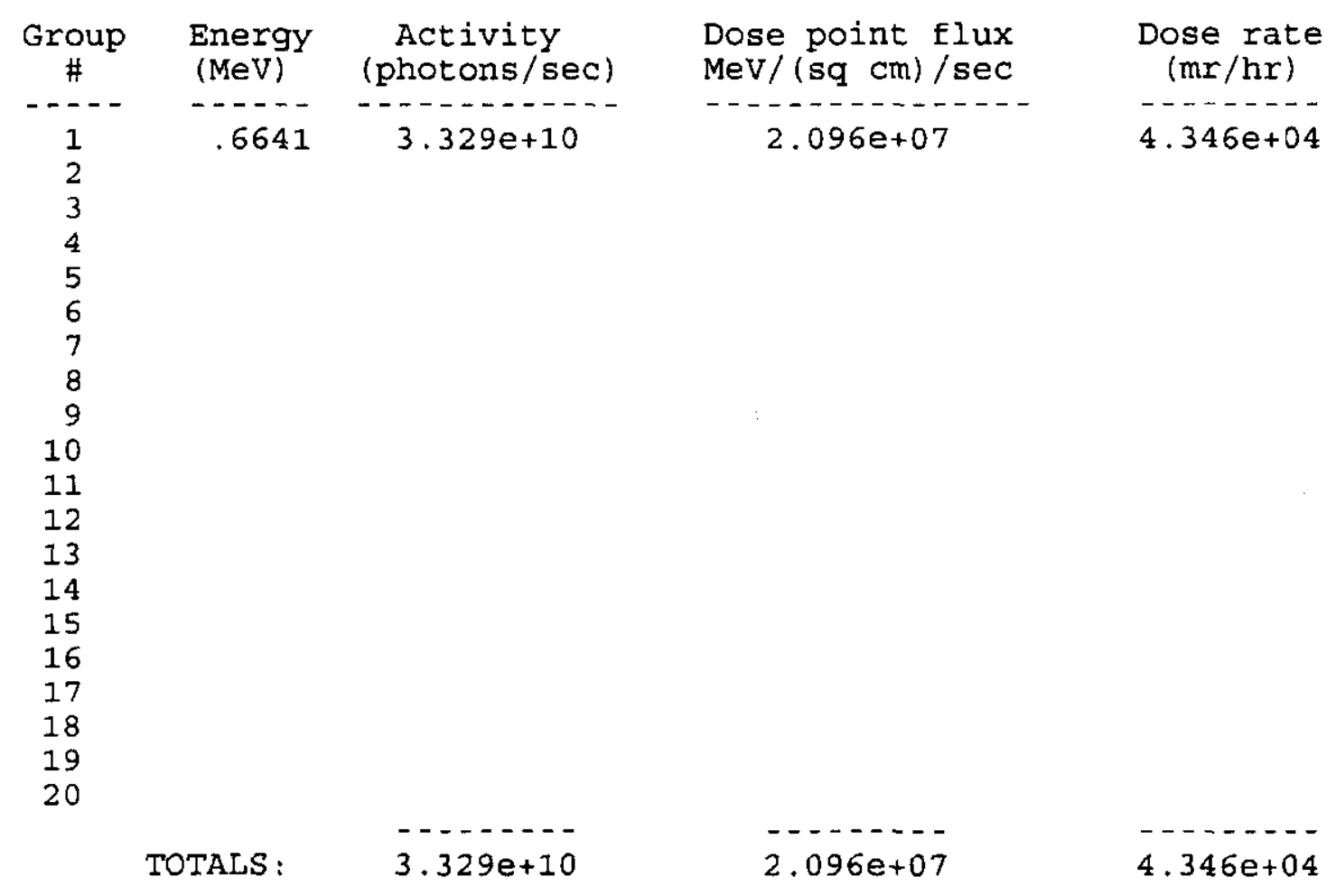


Microshield 3.12

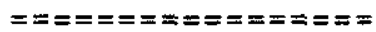
(Westinghouse Hanford Company - \#197)

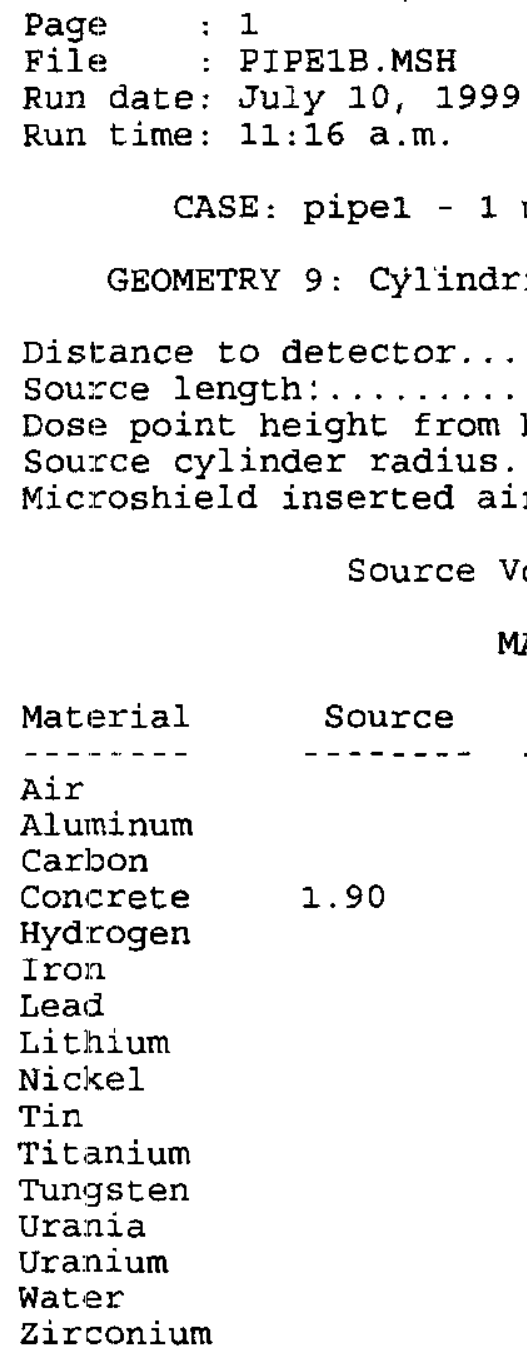

CASE: pipel - 1 meter pipe, 2 in. id, no dilution, $34 \mathrm{~cm}$ GEOMETRY 9: Cýlindrical source from side - combination shields 
Page 2

File: PIPE1B.MSH CASE: pipel - 1 meter pipe, 2 in. id, no dilution, $34 \mathrm{~cm}$

BUILDUP FACTOR: based on GP method. Using the characteristics of the materials in shield 1 .

\section{INTEGRATION PARAMETERS :}

Number of lateral angle segments (Ntheta)..... 51 Number of azimuthal angle segments (Npsi)..... 51 Number of radial segments (Nradius).......... 51

SOURCE NUCLIDES :

\begin{tabular}{llllll} 
Nuclide & Curies & Nuclide & Curies & Nuclide & Curies \\
\hdashline$-\cdots-137 \mathrm{~m}$ & $1.0000 \mathrm{e}+00$ & $\mathrm{C}-60$ & $0.0000 \mathrm{0}+00$ & $\mathrm{Cs}-137$ & $1.0000 \mathrm{0}+00$ \\
$\mathrm{Ba}-16$ & $0.0000 \mathrm{e}+00$ & & & &
\end{tabular}

RESULTS :

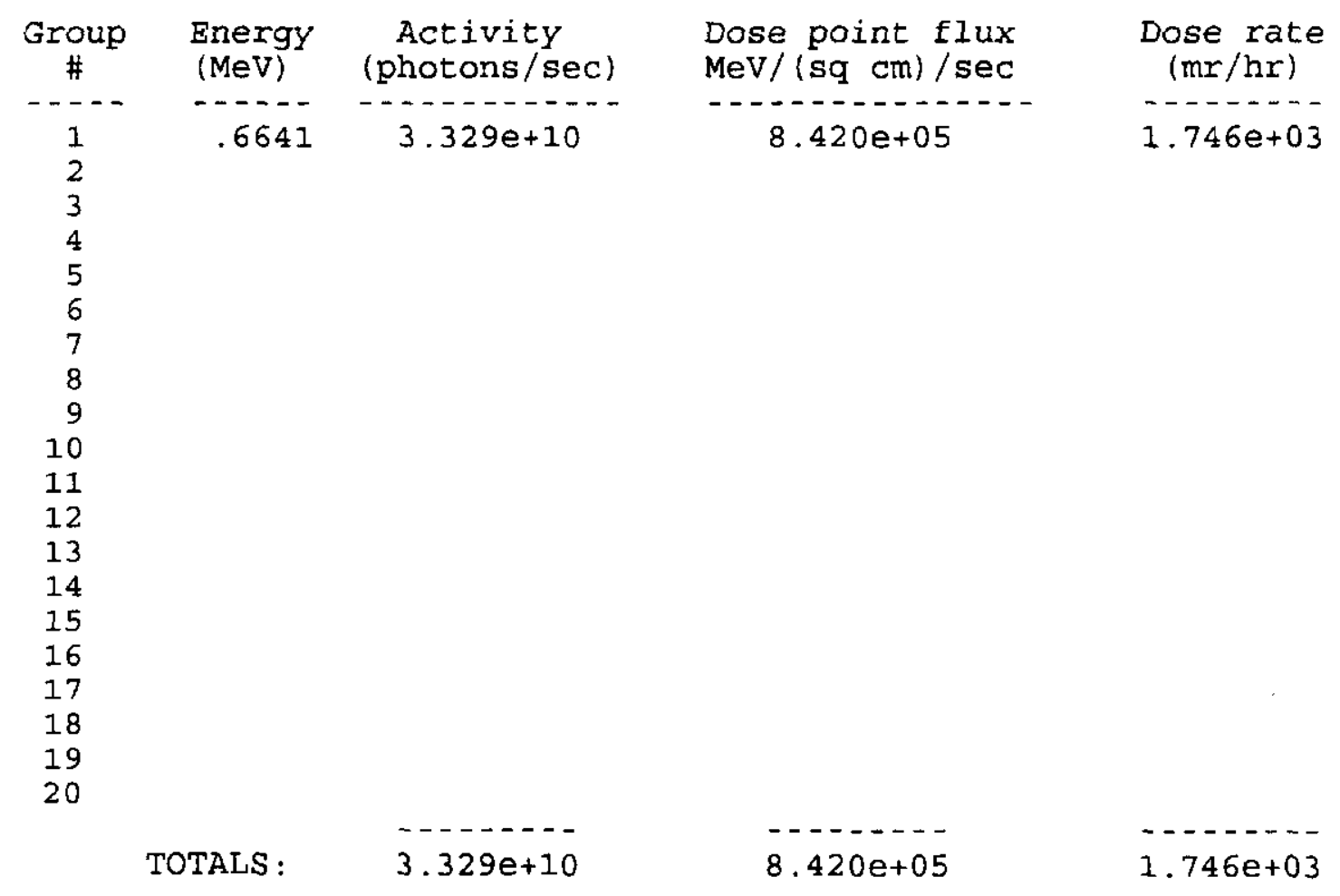


Microshield 3.12

\[ =========== \pm= \]
(Westinghouse Hanford Company - \#197)

Page : 1

File : PIPEIC.MSH

Run date: July 10, 1999

Run time: $11: 21 \mathrm{a} . \mathrm{m}$.

File Ref:

Date:

By:

Checked:

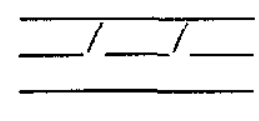

CASE: pipel - 1 meter pipe, 2 in. id, no dilution, $100 \mathrm{~cm}$ GEOMETRY 9: Cylindrical source from side - combination shields

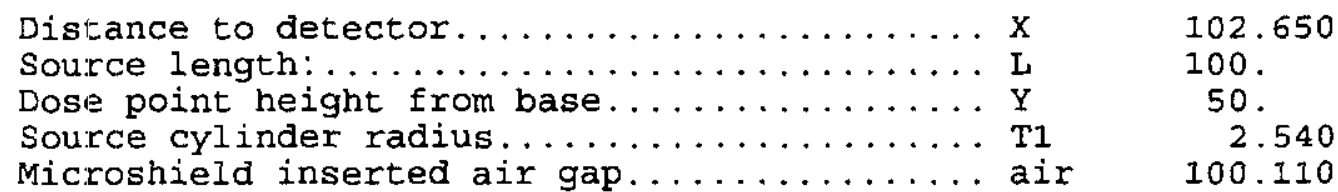

cm.

$"$

$n$

$n$

Source volume: 2026.83 cubic centimeters

MATERIAL DENSITIES $(\mathrm{g} / \mathrm{cc})$ :

Material

-.....-

Air

Aluminum

Caribon

Concrete

Hydrogen

Iron

Lead

Lithium

Nickel

$\mathrm{Tin}$

Titanium

Tungsten

Urania

Uranium

Water

Zirconium

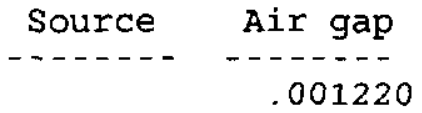

1.90 
SNF-10272 REV. 2

Page 2

File: PIPE1C.MSH

CASE: pipel - 1 meter pipe, 2 in. id, no dilution, $100 \mathrm{~cm}$

BUILDUP FACTOR: based on GP method.

Using the characteristics of the materials in shield 1 .

\section{INTEGRATION PARAMETERS:}

Number of lateral angle segments (Ntheta).... 51

Number of azimuthal angle segments (Npsi)..... 51

Number of radial segments (Nradius) ........... 51

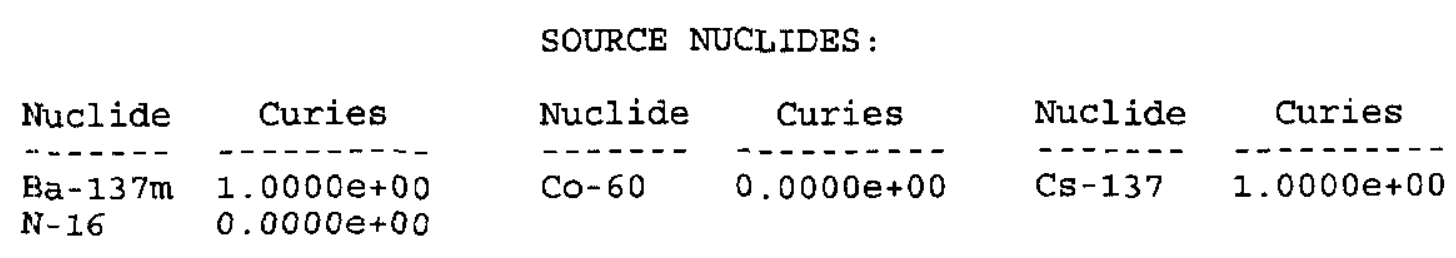

RESULTS :

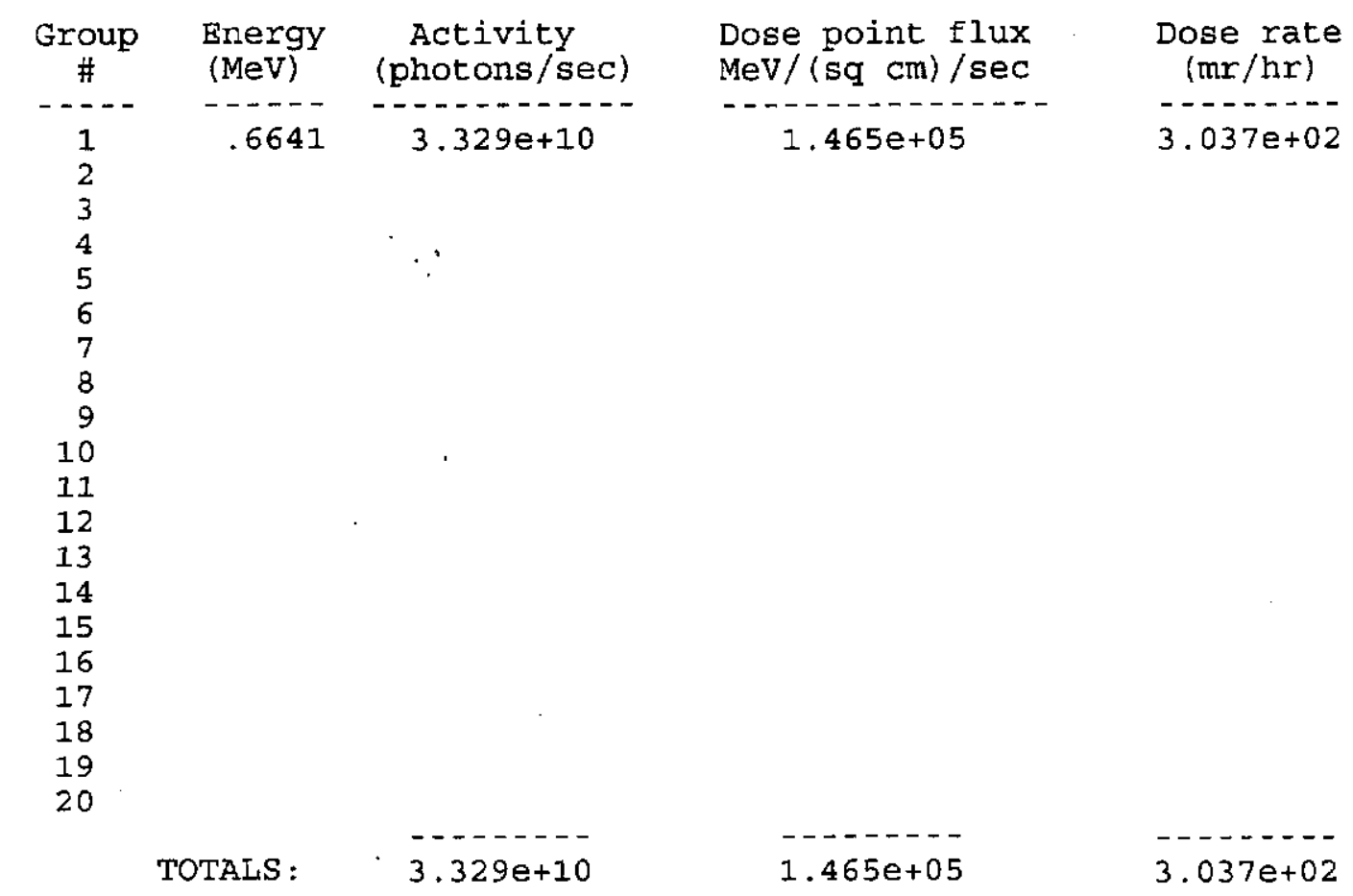




\section{Microshield 3.12}

$===x========== \pm$

Page : 1

File : PIPE2A.MSH

Run date: July 10, 1999

Run time: $11: 25$ a.m.

\#197)
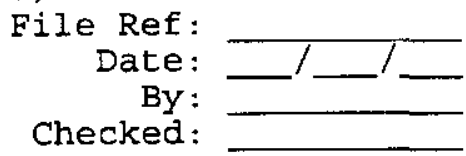

CASE: pipel - 1 meter pipe, 2 in. id, $30 \%, 0 \mathrm{~cm}$ GEOMETRY 9: Cylindrical source from side - combination shields

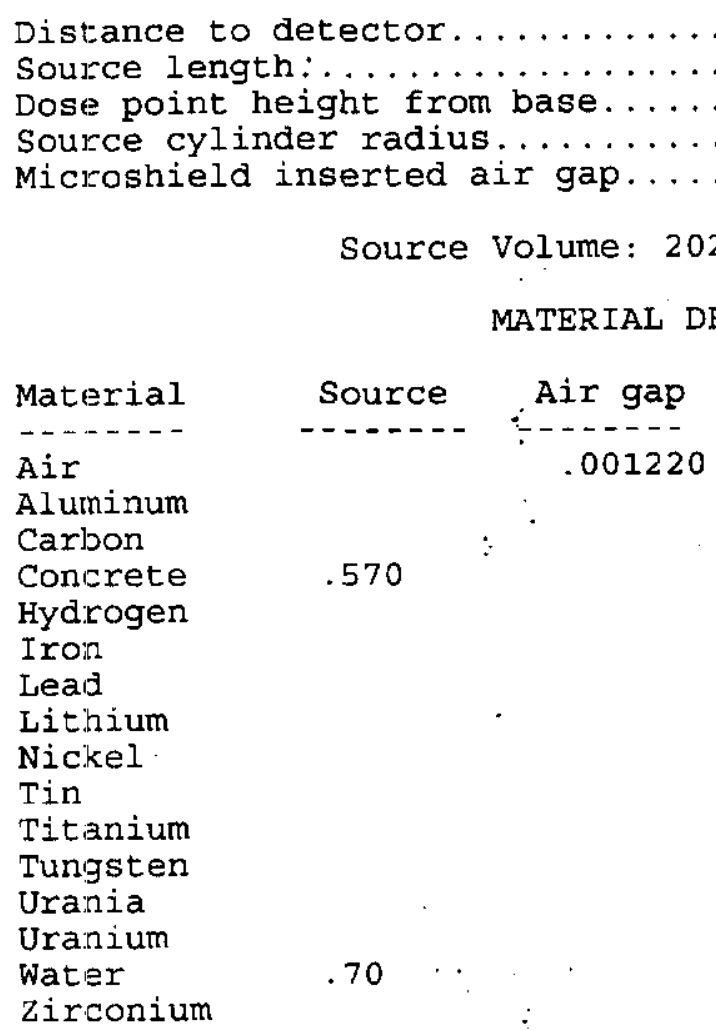




\section{SNF-10272 REV. 2}

Page 2

File: PIPE2A.MSH

CASE: pipel - 1 meter pipe, 2 in. id, 30\%, $0 \mathrm{~cm}$

BUILDUP FACTOR: based on GP method.

Using the characteristics of the materials in shield 1 .

\section{INTEGRATION PARAMETERS :}

Number of lateral angle segments (Ntheta)..... 51

Number of azimuthal angle segments (Npsi)..... 51

Number of radial segments (Nradius).......... 51

\begin{tabular}{llllll} 
Nuclide & Curies & Nuclide & Curies & Nuclide & Curies \\
\hdashline $\mathrm{Ba}-137 \mathrm{~m}$ & $1.0000 \mathrm{D}+00$ & $\mathrm{C}-60$ & $0.0000 \mathrm{0}+00$ & $\mathrm{Cs}-137$ & $1.0000 \mathrm{e}+00$ \\
$\mathrm{~N}-16$ & $0.0000 \mathrm{0}+00$ & & & &
\end{tabular}

RESULTS :

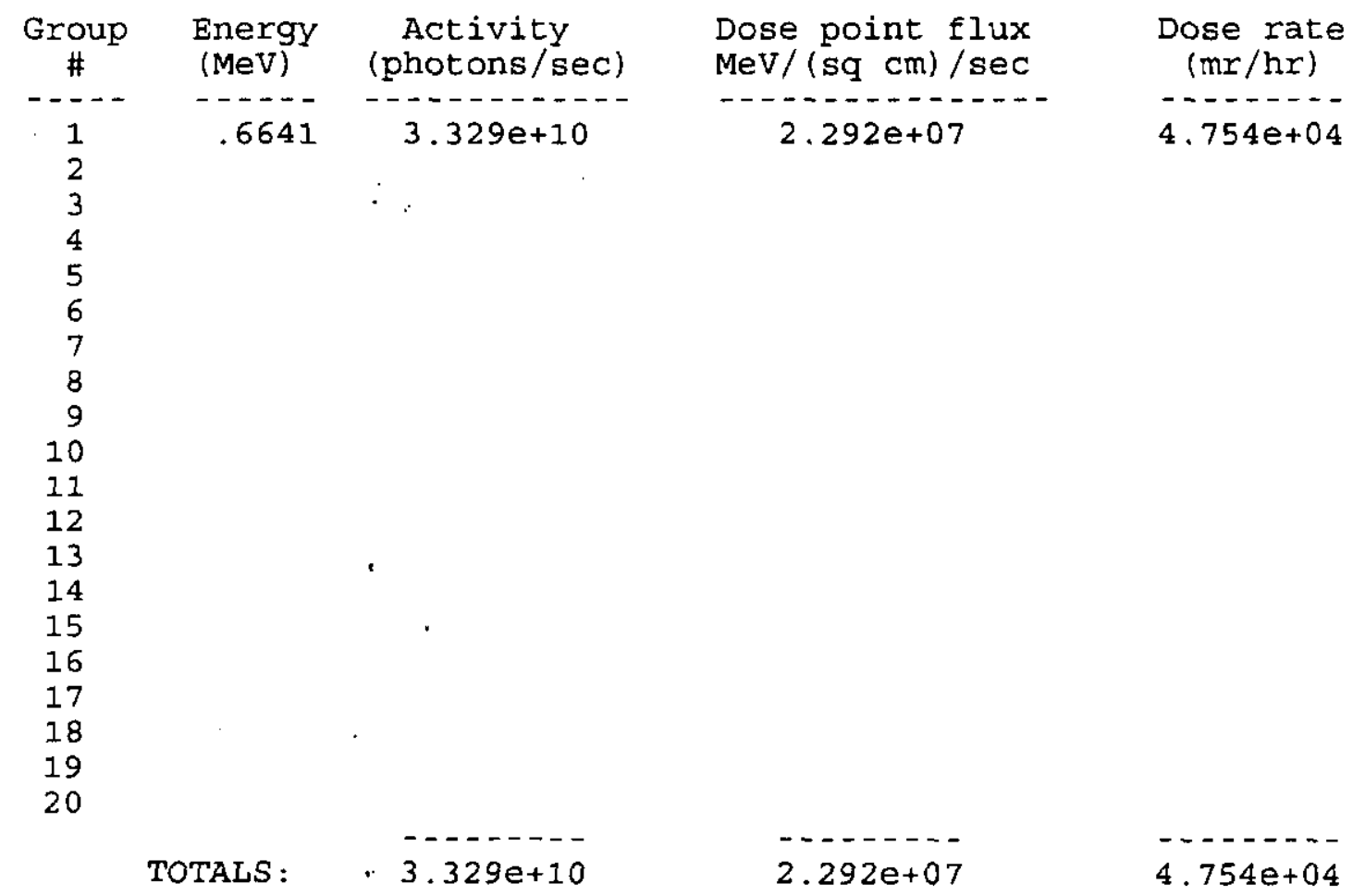


SNF-10272 REV. 2

Microshield 3.12

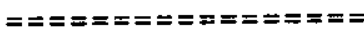

(Westinghouse Hanford Company - \#197)

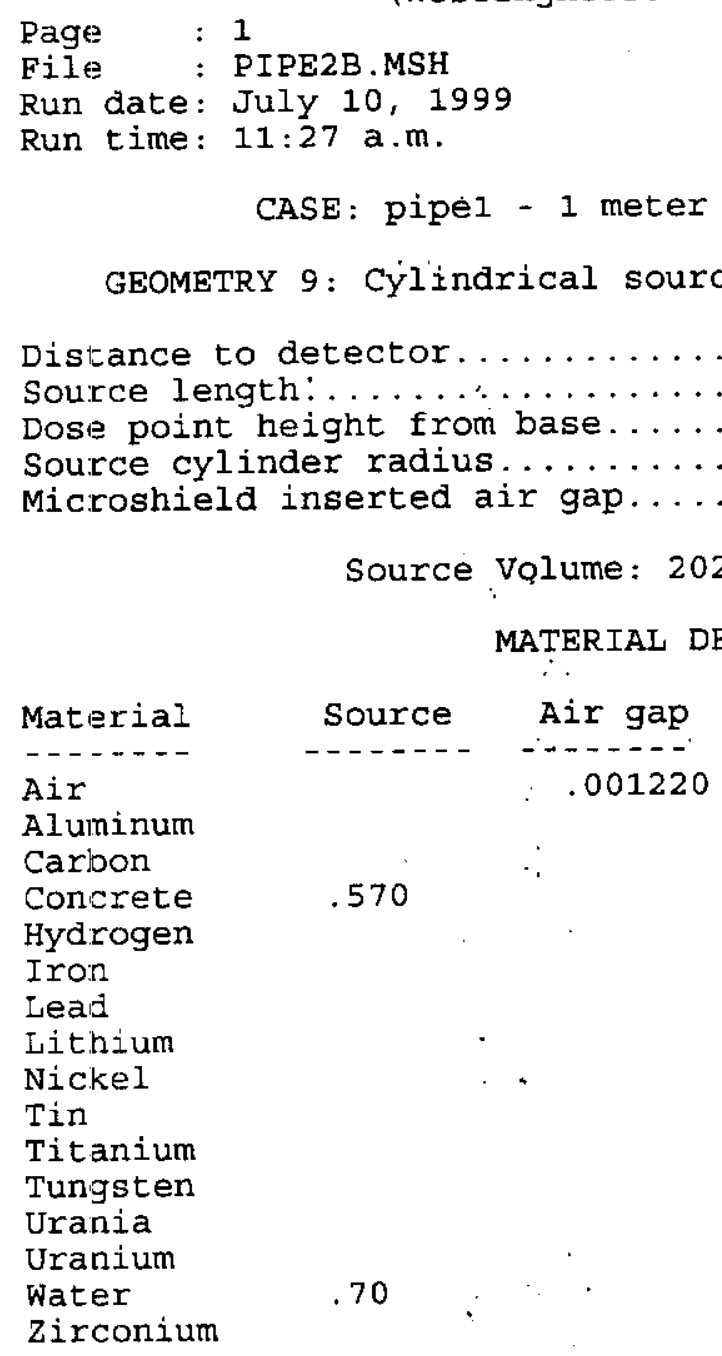

File Ref:

Date:

By :

Checked :

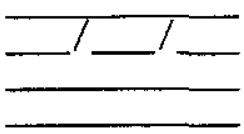

pipe, 2 in. id, $30 \%, 34 \mathrm{~cm}$

from side - combination shields 
Page 2

File: PIPE2B.MSH

CASE: pipel - 1 meter pipe, 2 in. id, $30 \%, 34 \mathrm{~cm}$

BUILDUP FACTOR: based on GP method.

Using the characteristics of the materials in shield 1.

\section{INTEGRATION PARAMETERS:}

Number of lateral angle segments (Ntheta)....

Number of azimuthal angle segments (Npsi).....

Number of radial segments (Nradius) ..........

SOURCE NUCLIDES:

\begin{tabular}{llllll} 
Nuclide & Curies & Nuclide & Curies & Nuclide & Curies \\
\hdashline $\mathrm{Ba}-137 \mathrm{~m}$ & $1.0000 \mathrm{e}+00$ & $-\mathrm{C}-60$ & $0.0000 \mathrm{0}+00$ & $\mathrm{Cs}-137$ & $1.0000 \mathrm{e}+00$ \\
$\mathrm{~N}-16$ & $0.0000 \mathrm{O}+00$ & & & &
\end{tabular}
RESULTS :

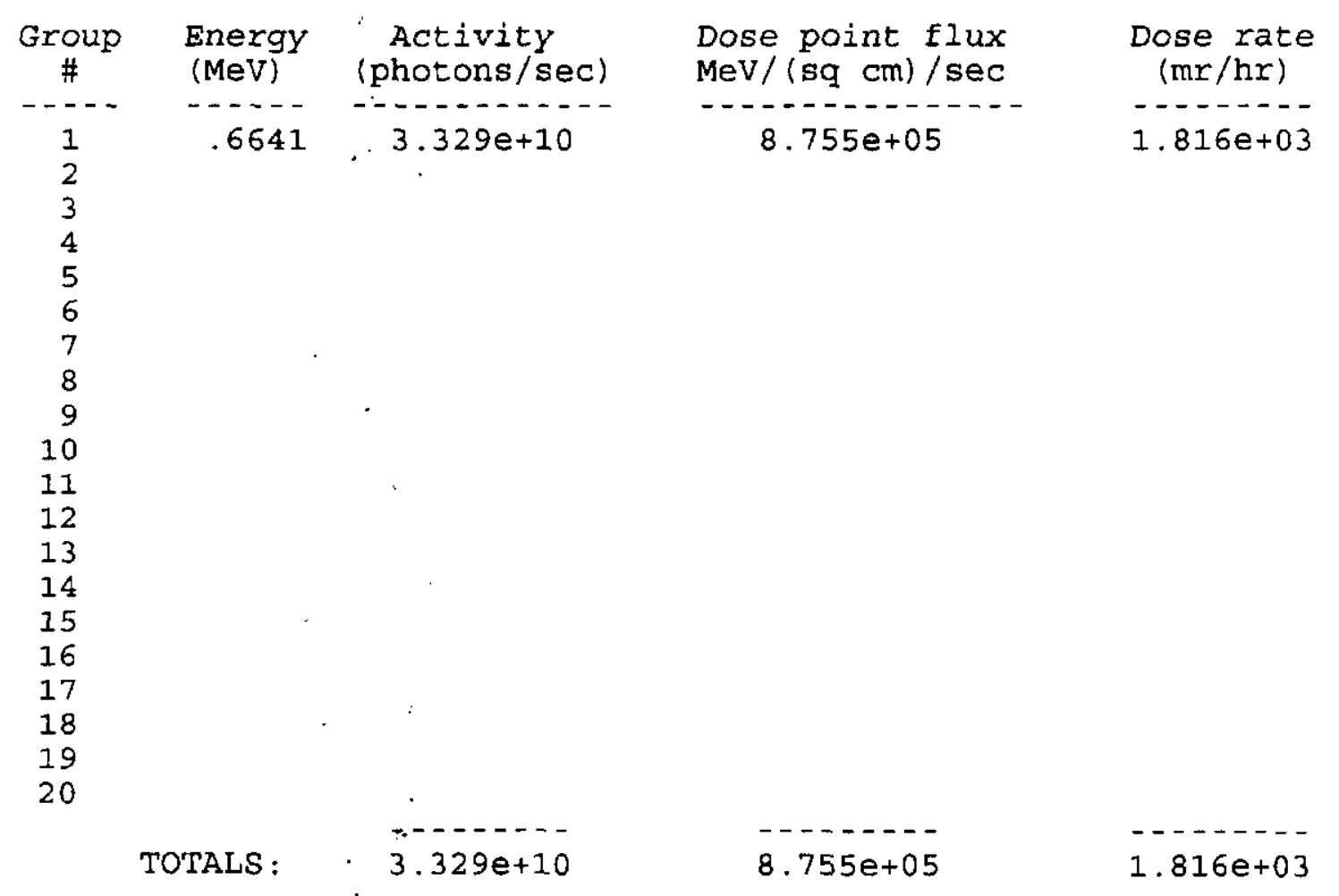


Microshield 3.12

$=== \pm==== \pm=== \pm=$

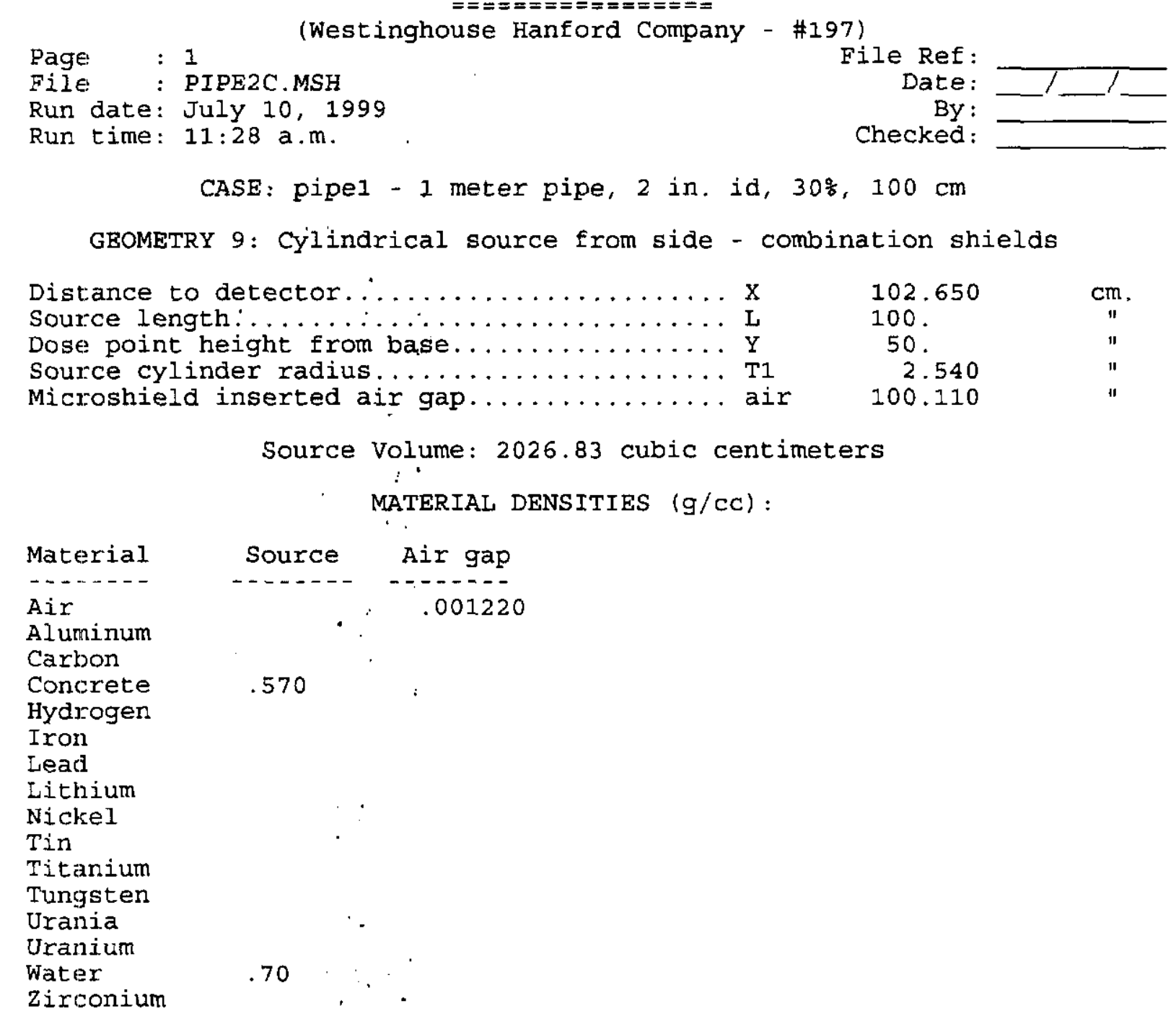


Page 2

File: PIPE2C.MSH

CASE: pipel - 1 meter pipe, 2 in. id, 30\%, $100 \mathrm{~cm}$

BUILDUP FACTOR: based on GP method.

Using the characteristics of the materials in shield 1 .

\section{INTEGRATION PARAMETERS:}

Number of lateral angle segments (Ntheta)..... 51

Number of azimuthal angle segments (Npsi)..... 51

Number of radial segments (Nradius).......... 51

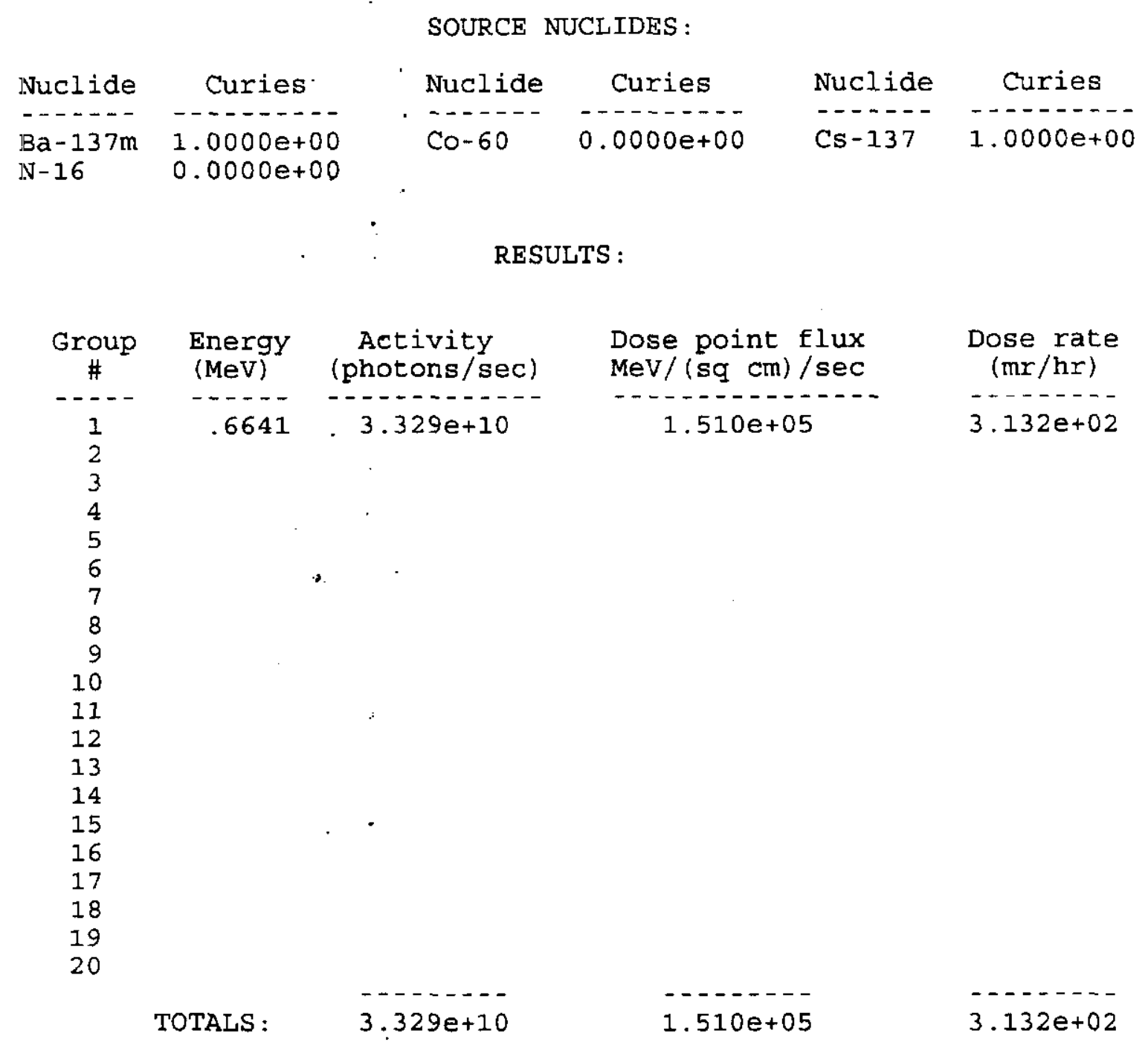


Microshield 3.12

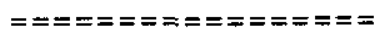

(Westinghouse Hanford Company - \#197)
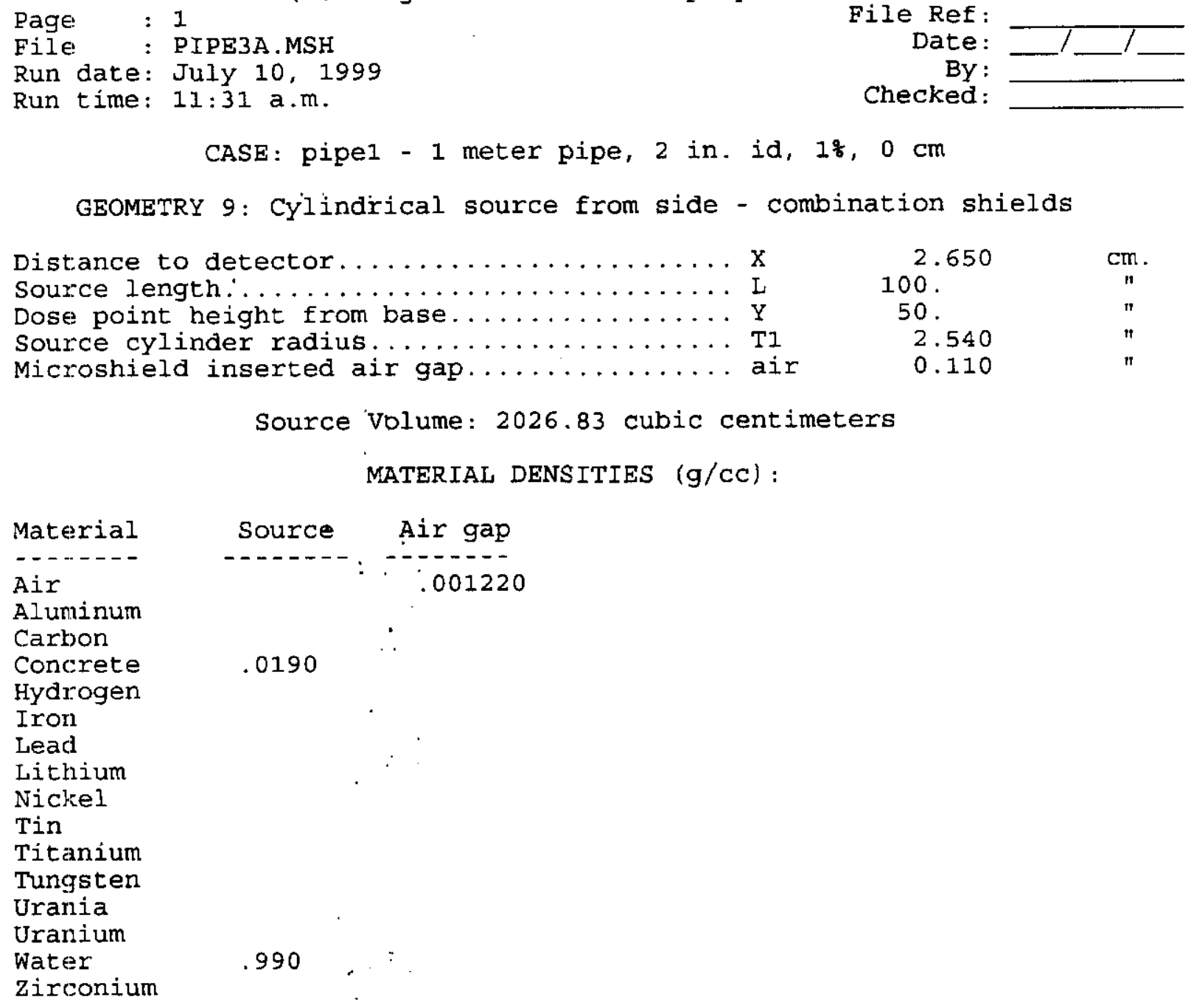

CASE: pipel - 1 meter pipe, 2 in. id, $1 \%, 0 \mathrm{~cm}$ GEOMETRY 9: CYiindrical source from side - combination shields 
Page 2

File: PIPE3A.MSH

CASE: pipel - 1 meter pipe, 2 in. $i d, 1 \frac{1}{6}, 0 \mathrm{~cm}$

BUILDUP FACTOR: based on GP method.

Using the characteristics of the materials in shield 1 .

INTEGRATION PARAMETERS :

Number of lateral angle segments (Ntheta)..... 51

Number of azimuthal angle segments (Npsi) .....

Number of radial segments (Nradius).......... 51

\begin{tabular}{|c|c|c|c|c|c|}
\hline Nuclide & Curies & Nuclide & Curies & Nuclide & Curies \\
\hline------ & $-\cdots-\cdots--$ & ----- & $------\overline{-}$ & ----- & \\
\hline $\begin{array}{l}\mathrm{Ba}-137 \mathrm{~m} \\
\mathrm{~N}-16\end{array}$ & $\begin{array}{l}1.0000 e+00 \\
0.0000 e+00\end{array}$ & $\mathrm{Co}-60$ & $0.0000 e+00$ & Cs -137 & $1.0000 e+00$ \\
\hline
\end{tabular}

RESULTS :

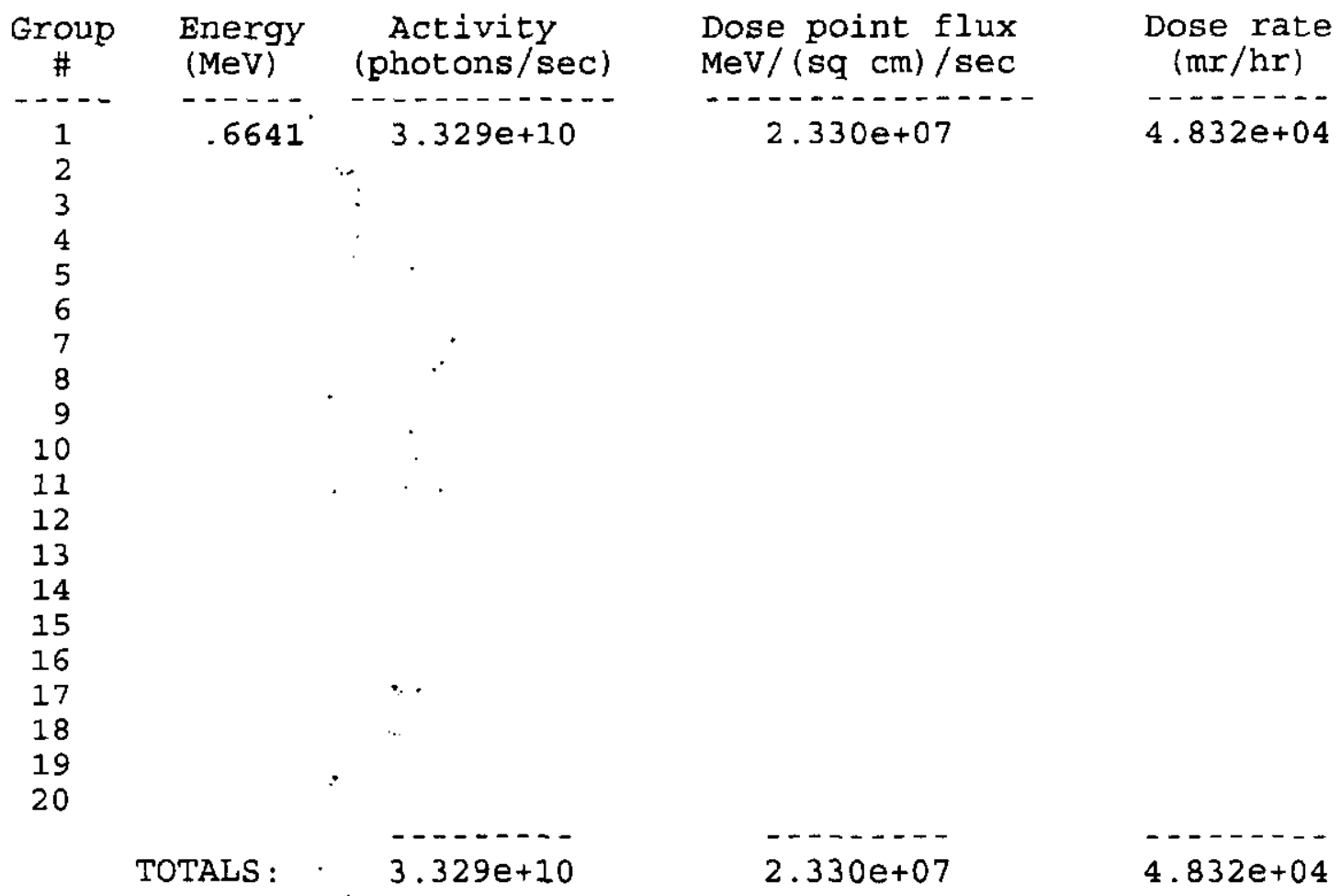




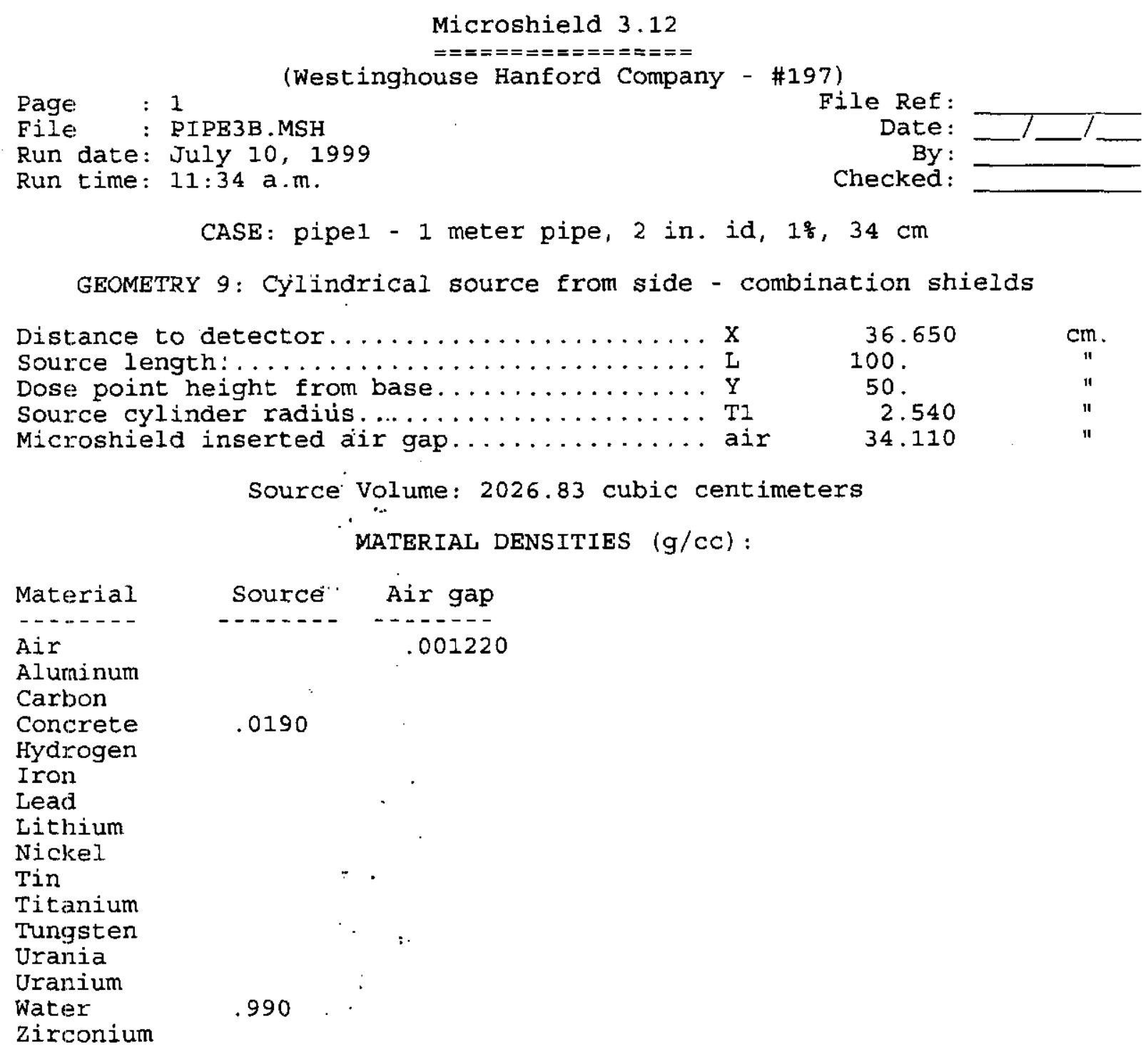


Page 2

File: PIPE3B.MSH

CASE: pipe1 - 1 meter pipe, 2 in. id, $18,34 \mathrm{~cm}$

BUILDUP FACTOR: based on GP method.

Using the characteristics of the materials in shield 1 .

\section{INTEGRATION PARAMETERS :}

Number of lateral angle segments (Ntheta)..... 51

Number of azimuthal angle segments (Npsi)..... 51

Number of radial segments (Nradius).......... 51

SOURCE NUCLIDES :

\begin{tabular}{llllll} 
Nuclide & Curies & Nuclide & Curies & Nuclide & Curies \\
\hdashline $\mathrm{Ba}-137 \mathrm{~m}$ & $1.0000 \mathrm{e}+00$ & Co-60 & $0.0000 \mathrm{e}+00$ & $\mathrm{Cs}-137$ & $1.0000 \mathrm{e}+00$ \\
$\mathrm{~N}-16$ & $0.0000 \mathrm{e}+00$ & & & &
\end{tabular}

RESULTS :

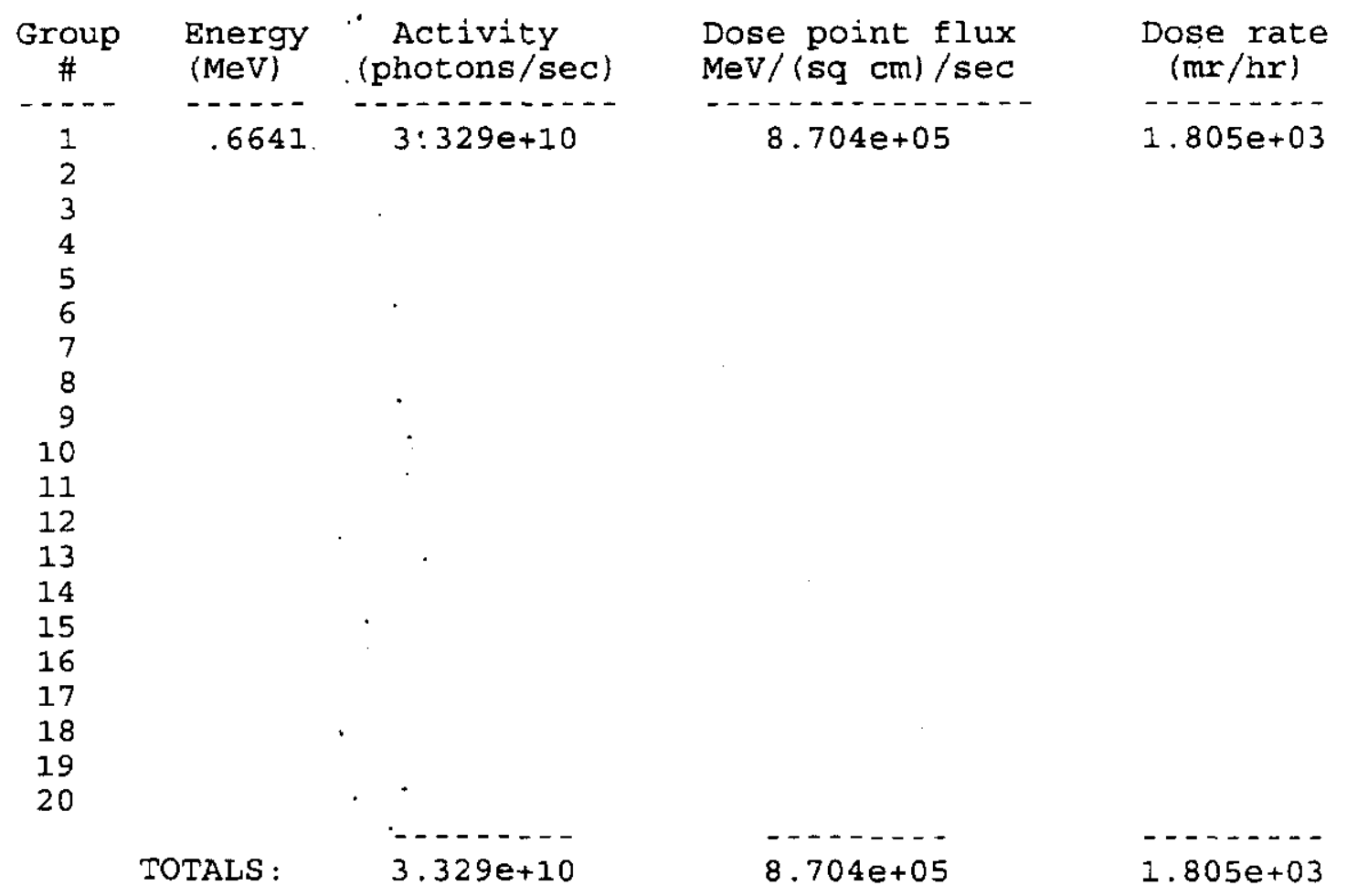


Microshield 3.12

$==x=x= \pm==== \pm===$ (Westinghouse Hanford Company - \#197)

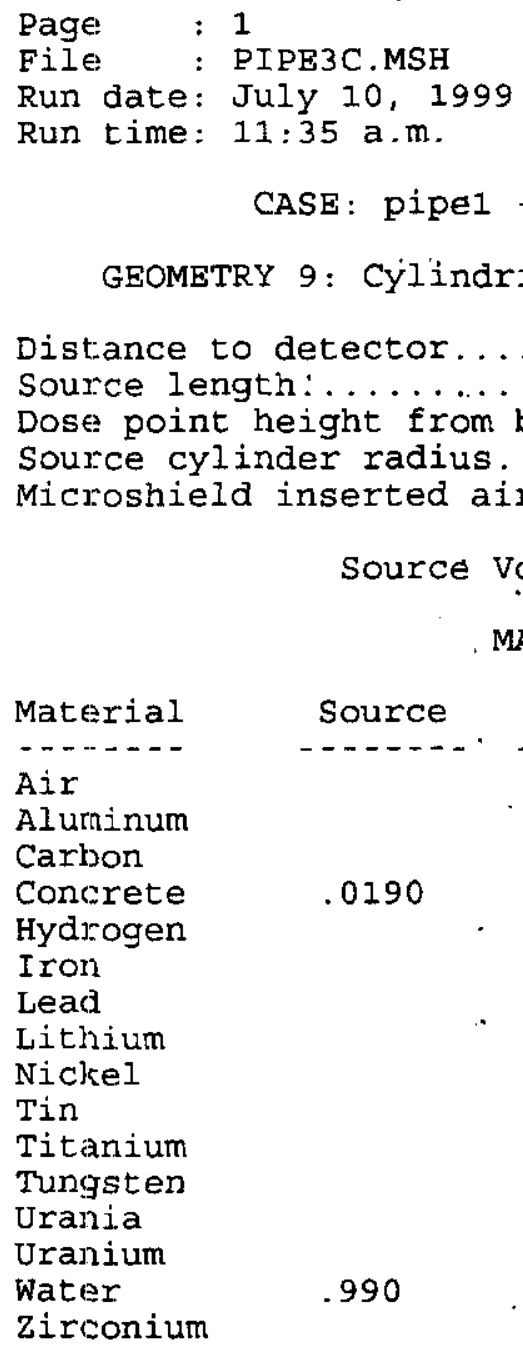

Material

Air

Alurninum

Carbon

Concrete

Hydrogen

Iron

Lead

Lithium

Nickel

Tin

Titanium

Tungsten

Urania

Uranium

Water

zirconium

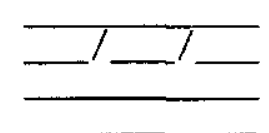

CASE: pipe1 - 1 meter pipe, 2 in. id, 1\%, $100 \mathrm{~cm}$ GEOMETRY 9: Cylindrical source from side - combination shields

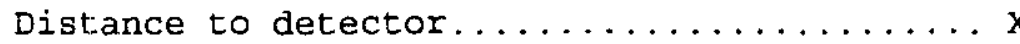
Source length:..................... L Dose point height from base............ Y Source cylinder radius................ T1 Microshield inserted air gap............ air

102.650
100.
50.
2.540
100.110

$\mathrm{cm}$.
$"$
$"$
$"$
$"$

Source Volume: 2026.83 cubic centimeters

MATERIAL DENSITIES $(\mathrm{g} / \mathrm{CC})$ : 
Page 2

File: PIPE3C.MSH

CASE: pipel - 1 meter pipe, 2 in. id, $1 \frac{9}{6}, 100 \mathrm{~cm}$

BUILDUP FACTOR: based on GP method.

Using the characteristics of the materials in shield 1.

\section{INTEGRATION PARAMETERS :}

Number of lateral angle segments (Ntheta) ..... 51

Number of azimuthal angle segments (Npsi) ..... 51

Number of radial segments (Nradius) .......... 51

SOURCE NUCLIDES:

\begin{tabular}{llllll} 
Nuclide & Curies & Nuclide & Curies & Nuclide & Curies \\
\hdashline $\mathrm{Ba}-137 \mathrm{~m}$ & $\mathbf{1 . 0 0 0 0 e + 0 0}$ & $\mathrm{Co}-60$ & $0.0000 \mathrm{0}+00$ & $\mathrm{Cs}-137$ & $1.0000 \mathrm{0}+00$ \\
$\mathrm{~N}-16$ & $0.0000 \mathrm{e}+00$ & & & &
\end{tabular}

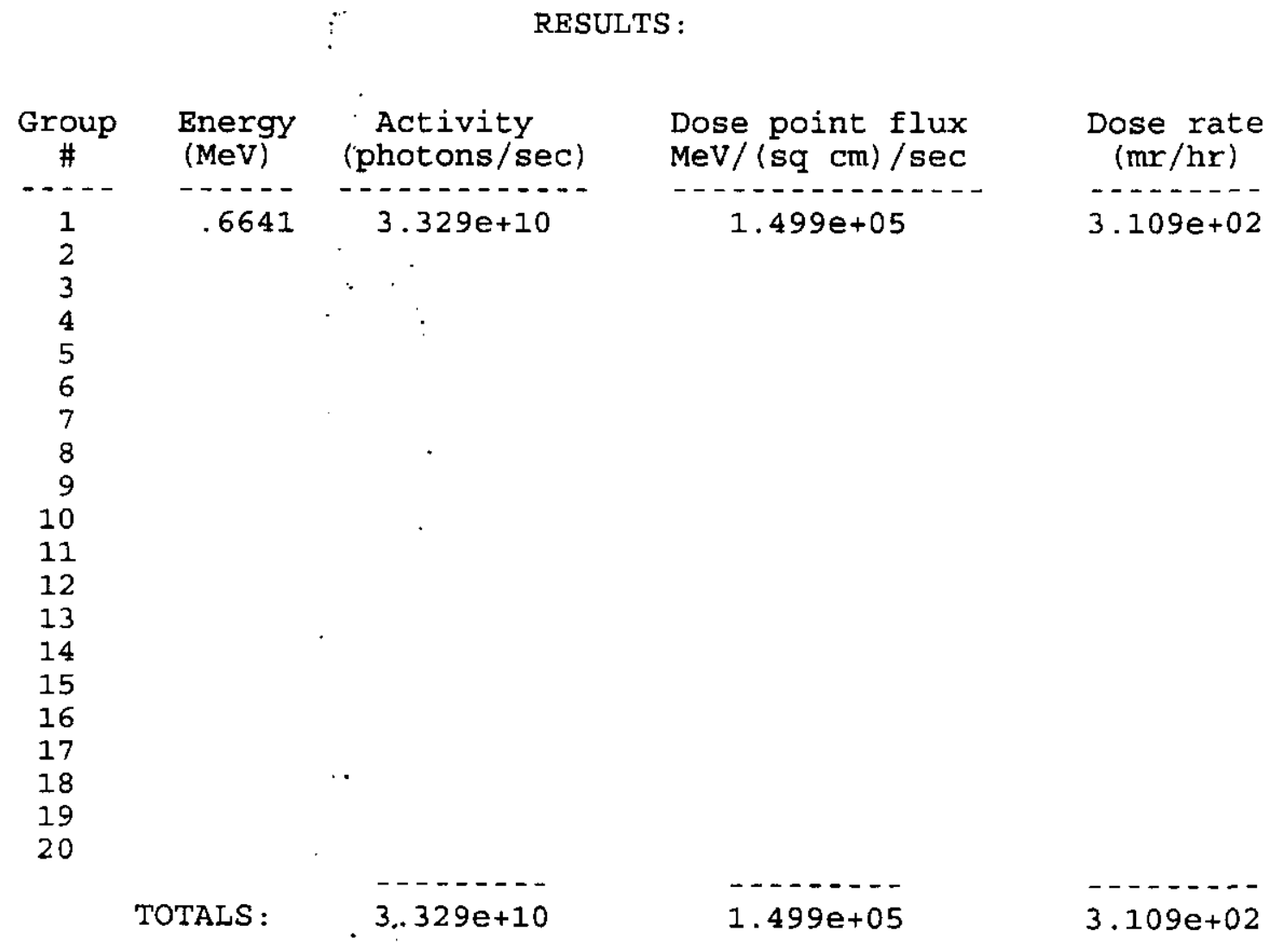


SNF-10272 REV. 2

This page is intentionally left blank 


\section{APPENDIX F - PEER REVIEW CHECKLISTS}

Appendix F contains the peer review checklists for Revision 2. Sections were reviewed by the personnel identified in Table F-1 below.

\begin{tabular}{|l|l|l|}
\hline \multicolumn{3}{|c|}{ Table F-1. Revision 2 Peer Review Matrix } \\
\hline Section & Section Author & Peer Reviewer \\
\hline 3.1 & J.C. Williams & D.M. Carson \\
\hline 3.2 & J.C. Williams & D.M. Carson \\
\hline 3.3 & J.C. Williams & D.A. Himes \\
\hline 3.4 .1 & J.C. Williams & D.A. Himes \\
\hline 3.4 .2 & J.C. Williams & D.A. Himes \\
\hline 3.4 .3 & J.C. Williams & D.A. Himes \\
\hline 3.4 .4 & D.A. Himes & J.C. Williams \\
\hline 3.4 .5 & D.A. Himes & J.C. Williams \\
\hline 3.4 .6 & R.M. Marusich & D.A. Himes \\
\hline 3.4 .7 & R.M. Marusich & D.A. Himes \\
\hline 3.4 .8 & J.C. Williams & D.A. Himes \\
\hline 3.4 .9 & J.C. Williams & D.A. Himes \\
\hline 3.4 .10 & J.C. Williams & D.A. Himes \\
\hline 3.4 .11 & J.C. Williams & D.A. Himes \\
\hline 3.4 .12 & Not changed for Rev. 2 \\
\hline 3.4 .13 & D.A. Himes & J.C. Williams \\
\hline 3.4 .14 & J.C. Williams & D.A. Himes \\
\hline 3.4 .15 & J.C. Williams & D.A. Himes \\
\hline 3.4 .16 & J.C. Williams & D.A. Himes \\
\hline 3.4 .17 & J.C. Williams & D.A. Himes \\
\hline 3.4 .18 & J.C. Williams & D.A. Himes \\
\hline Appendix A & J.C. Williams & D.A. Himes \\
\hline Appendix B & R.M. Marusich & D.A. Himes \\
\hline Appendix C & R.M. Marusich & D.A. Himes \\
\hline Appendix D & D.A. Himes & B.E. Hey \\
\hline Appendix E & Not changed for Rev. 2 \\
\hline & & \\
\hline
\end{tabular}




\section{CHECKLIST FOR TECHNICAL PEER REVIEW}

Document Reviewed - SNF-10272 Rev. 2-assigned sections plus Appendices A, B, and C

Title: Accident Analysis and Control Options in Support of the Sludge Water System Safety Analysis

Author: various

Date: 10/21/03 Scope of Review: as shown in Table F-1

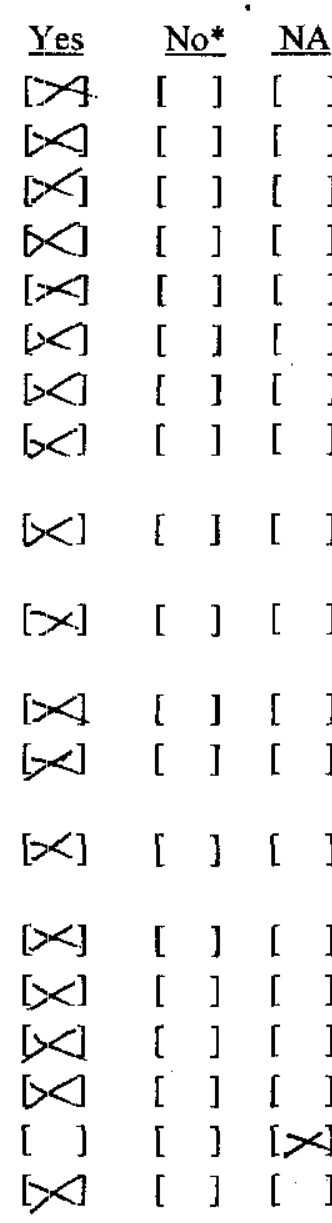

Referenced analyses appropriate.

Problem completely defined and all potential configurations considered.

Accident scenarios developed in a clear and logical manner.

Necessary assumptions explicitly stated and supported.

Computer codes and data files documented.

Data used in calculations explicitly stated in document.

Data checked for consistency with original source information as applicable.

Mathematical derivations checked including dimensional consistency of results

Models appropriate and used within range of validity, or use outside range of established validity justified.

Hand calculations checked for errors. Spreadsheet results should be treated exactly the same as hand calculations.

Software input correct and consistent with document reviewed.

Software output consistent with input and with results reported in document reviewed.

Limits/criteria/guidelines applied to analysis results are appropriate and referenced. Limits/criteria/guidelines checked against references.

Safety margins consistent with good engineering practices.

Conclusions consistent with analytical results and applicable limits.

Results and conclusions address all points required in the problem statement.

Format consistent with applicable guides or other standards.

** Review calculations, comments, and/or notes are attached.

Document approved (for example, the reviewer affirms the technical accuracy of the document).

D.A. Himes

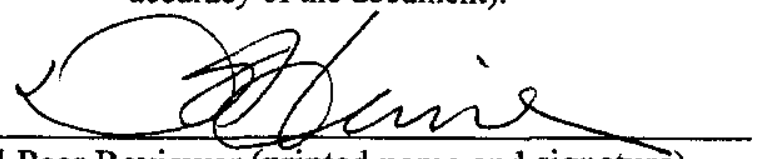

Technical Peer Reviewer (printed name and signature)

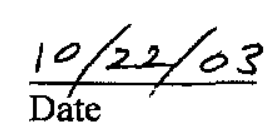

* All "no" responses must be explained below or on an additional sheet.

** Any calculations, comments, or notes generated as part of this review should be signed, dated and attached to this checklist. The material should be labeled and recorded in such a manner as to be understandable to a technically qualified third party. 


\section{CHECKLIST FOR TECHNICAL PEER REVIEW}

Document Reviewed - SNF-10272 Rev. 2 (Sections 3.1 and 3.2)

Title: Accident Analyses and Control Options in Support of the Sludge Water System Safety Analysis

Author: B.E. Hey, R.M.Marusich. D.A. Himes, D.M. Gerstner, and J.C. Williams

Date: 25 September 2003

\begin{tabular}{|c|c|c|c|}
\hline$\underline{\text { Yes }}$ & & * & \\
\hline$\left[\begin{array}{ll}{[} & ]\end{array}\right.$ & {[} & ] & \\
\hline ] & [ & ] & \\
\hline ] & [ & ] & \\
\hline ] & I & ] & \\
\hline ] & [ & ] & \\
\hline ] & I & ] & \\
\hline ] & [ & ] & \\
\hline 1 & {[} & ] & \\
\hline ] & [ & ] & \\
\hline ] & [ & ] & \\
\hline ] & [ & ] & \\
\hline ] & {[} & ] & \\
\hline ] & [ & ] & \\
\hline ] & [ & ] & \\
\hline ] & [ & ] & \\
\hline ] & [ & ] & \\
\hline $\mathrm{X}]$ & [ & ] & \\
\hline ] & I & ] & \\
\hline$X]$ & [ & ] & \\
\hline
\end{tabular}

Referenced analyses appropriate.

Problem completely defined and all potential configurations considered.

Accident scenarios developed in a clear and logical manner.

Necessary assumptions explicitly stated and supported.

Computer codes and data files documented.

Data used in calculations explicitly stated in document.

Data checked for consistency with original source information as applicable.

Mathematical derivations checked including dimensional consistency of results

Models appropriate and used within range of validity, or use outside range of established validity justified.

Hand calculations checked for errors. Spreadsheet results should be treated exactly the same as hand calculations.

Software input correct and consistent with document reviewed.

Software output consistent with input and with results reported in document reviewed.

Limits/criteria/guidelines applied to analysis results are appropriate and referenced. Limits/criteria/guidelines checked against references.

Safety margins consistent with good engineering practices.

Conclusions consistent with analytical results and applicable limits.

Results and conclusions address all points required in the problem statement.

Format consistent with applicable guides or other standards.

** Review calculations, comments, and/or notes are attached.

Document approved (for example, the reviewer affirms the technical accuracy of the document).
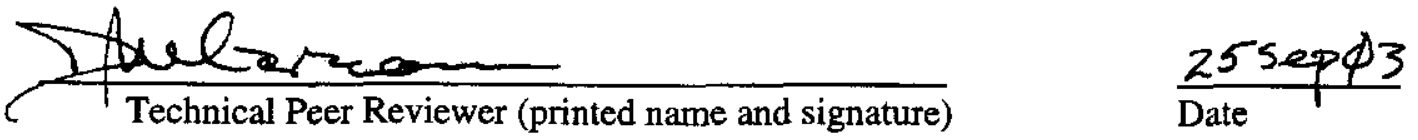

* All "no" responses must be explained below or on an additional sheet.

** Any calculations, comments, or notes generated as part of this review should be signed, dated and attached to this checklist. The material should be labeled and recorded in such a manner as to be understandable to a technically qualified third party. 


\title{
CHECKLIST FOR TECHNICAL PEER REVIEW
}

\author{
Document Reviewed - SNF-10272 Section 3.4.4
}

Title: Cask Overpressurization

Author: D.A. Himes

Date: September 252003

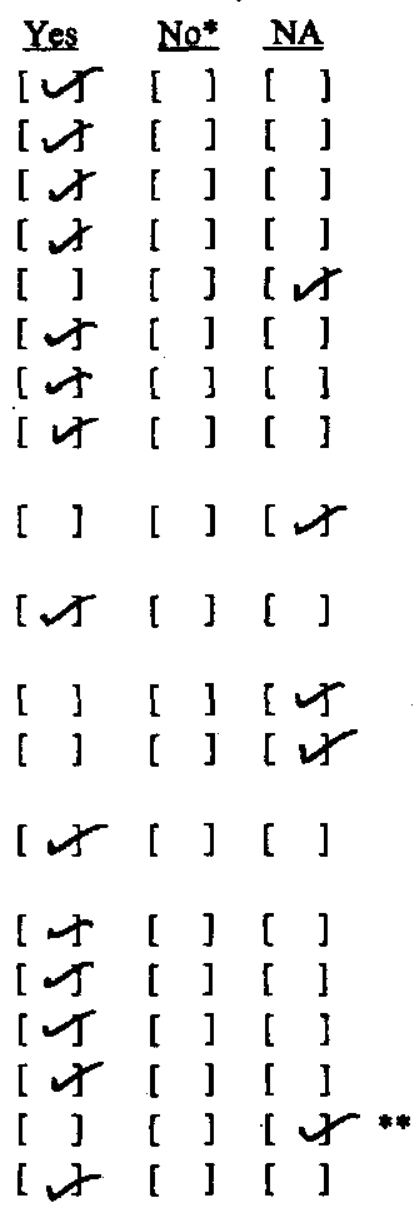

Referenced analyses appropriate.

Problem completely defined and all potential configurations considered.

Accident scenarios developed in a clear and logical manner.

Necessary assumptions explicitly stated and supported.

Computer codes and data files documented.

Data used in calculations explicitly stated in document.

Data checked for consistency with original source information as applicable.

Mathematical derivations checked including dimensional consistency of results

Models appropriate and used within range of validity, or use outside range of establishod validity justified.

Hand calculations checked for errors. Spreadsheet results should be treated exactly the same as hand calculations.

Software input correct and consistent with document reviewed.

Software output consistent with input and with results reported in document reviewed.

Limits/criteria/guidelines applied to analysis results are appropriate and referenced. Limits/criteria/guidelines checked against references.

Safety margins consistent with good engineering practices.

Conclusions consistent with analytical results and applicable limits.

Results and conclusions address all points required in the problem statement.

Format consistent with applicable guides or other standands.

Review calculations, comments, and/or notes are attached.

Document approved (for example, the reviewer affirms the technical accuracy of the document).
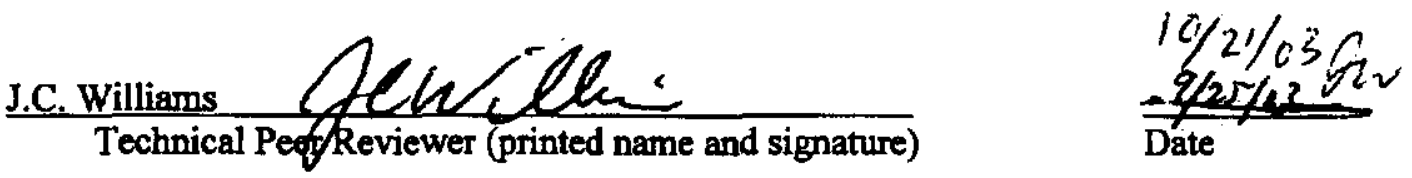

* All "no" responses must be explained below or on an additional sheet.

** Any calculations, comments, or notes generated as part of this review should be signed, dated and attached to this checklist. The material should be labeled and recorded in such a manner as to be understandable to a technically qualified third party. 


\section{CHECKLIST FOR TECHNICAL PEER REVIEW}

Document Reviewed - SNF-10272 Section 3.4.5

Title: LDC Overpressurization

Author: D.A. Himes

Date: September 252003

\begin{tabular}{|c|c|c|}
\hline Yes & $\underline{\mathrm{No}^{*}}$ & NA \\
\hline [ U & [ ] & {[]} \\
\hline & {$\left[\begin{array}{ll}\text { l } \\
\text {. }\end{array}\right.$} & {$\left[\begin{array}{ll}{[} & 1\end{array}\right.$} \\
\hline & [ ] & {[]} \\
\hline$r$ & {[]} & [ ] \\
\hline & {[]} & [ J \\
\hline & {[]} & {$\left[\begin{array}{ll}{[} & ]\end{array}\right.$} \\
\hline & {$\left[\begin{array}{l}{[} \\
{[}\end{array}\right.$} & [ ] \\
\hline$[x$ & {[]} & [ ] \\
\hline & [ ] & [ ] \\
\hline & [ ] & {$\left[\begin{array}{ll}\text { ] } \\
\text {. }\end{array}\right.$} \\
\hline [ & {[]} & \\
\hline$\left[\begin{array}{ll}1 \\
0\end{array}\right.$ & [ ] & \\
\hline & {$\left[\begin{array}{ll}1 & \end{array}\right.$} & [ ] \\
\hline$[x$ & [ ] & [ ] \\
\hline & [ ] & [ ] \\
\hline & [ ] & \\
\hline & [ ] & \\
\hline & $\begin{array}{ll}{[} & ] \\
{[} & ]\end{array}$ & {$\left[\begin{array}{ll}{[} & 1 \\
{[} & 1\end{array}\right]$} \\
\hline
\end{tabular}

Referenced analyses appropriate.

Problem completely defined and all potential configurations considered.

Accident scenarios developed in a clear and logical manner.

Necessary assumptions explicitly stated and supported.

Computer codes and data files documented.

Data used in calculations explicitly stated in document.

Data checked for consistency with original sounce information as applicable.

Mathematical derivations checked including dimensional consistency of results

Models appropriate and used within range of validity, or use outside range of established validity justified.

Hand calculations checked for errors. Spreadshoet results should be treated exactly the same as hand calculations.

Software input correct and consistent with document reviewed.

Software output consistent with input and with results reported in document reviowed.

Limits/criteria/guidelines applied to analysis results are appropriate and referenced. Limits/criteria/guidelines checked against references.

Safety margins consistent with good engineering practices.

Conclusions consistent with analytical results and applicable limits.

Results and conclusions address all points required in the problem statement.

Format consistent with applicable guides or other standards.

Review calculations, comments, and/or notes are attached.

Document approved (for example, the reviewer affirms the tecbnical accuracy of the document).

J.C. Williams

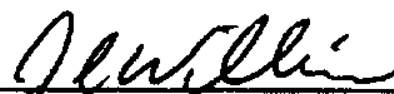

Technical Peer Rofiewer (printed name and signature)

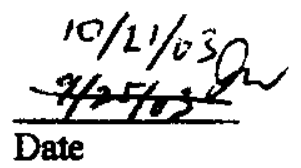

* All "no" responses must be explained below or on an additional sheet.

* Any calculations, comments, or notes generated as part of this review should be signed, dated and attached to this checklist. The material should be labeled and recorded in such a manner as to be understandable to a technically qualified third party. 


\section{CHECKLIST FOR TECHNICAL PEER REVIEW}

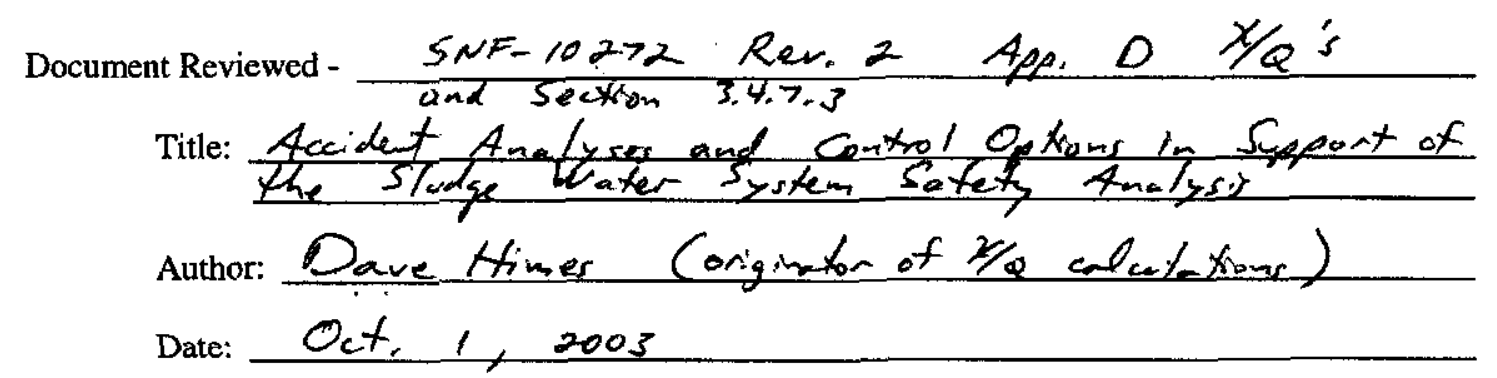

\begin{tabular}{|c|c|c|}
\hline & & \\
\hline & & \\
\hline & & \\
\hline & & \\
\hline & & \\
\hline & & \\
\hline & & \\
\hline & & \\
\hline & & \\
\hline Yes & No* & $\mathbf{N}$ \\
\hline & {$\left[\begin{array}{ll}{[} & ]\end{array}\right.$} & [ \\
\hline & {$\left[\begin{array}{ll}{[}\end{array}\right]$} & [ \\
\hline & {[]} & [ \\
\hline & {[]} & [ \\
\hline & {$\left[\begin{array}{l}{[} \\
\end{array}\right.$} & [ \\
\hline & & [ \\
\hline & & [ \\
\hline チ & & \\
\hline
\end{tabular}

[ l [ [ ] [ ]

[ ] [ ] [ U

[ ᄂ [ ] [ ]

[ut [ ] ]

[ ] [ ] [ ]

[ ] [ ] [4

[ ] [ ] [u

$\left[\begin{array}{llll}7 & 7\end{array}\right]$

[ ] [ ] [4

$\left[\begin{array}{lll}{[} & ] & {[}\end{array}\right] * *$

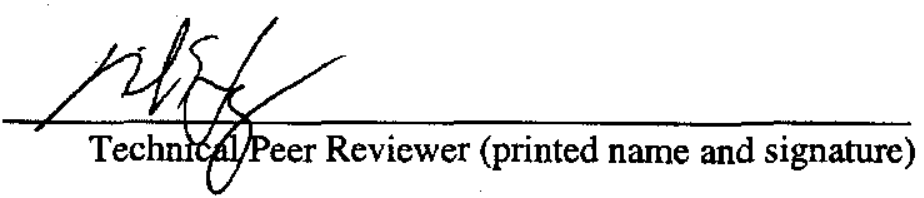

Referenced analyses appropriate.

Computer codes and data files documented. results established validity justified. exactly the same as hand calculations. reviewed. accuracy of the document).

Problem completely defined and all potential configurations considered.

Accident scenarios developed in a clear and logical manner.

Necessary assumptions explicitly stated and supported.

Data used in calculations explicitly stated in document.

Data checked for consistency with original source information as applicable.

Mathematical derivations checked including dimensional consistency of

Models appropriate and used within range of validity, or use outside range of

Hand calculations checked for errors. Spreadsheet results should be treated

Software input correct and consistent with document reviewed.

Software output consistent with input and with results reported in document

Limits/criteria/guidelines applied to analysis results are appropriate and referenced. Limits/criteria/guidelines checked against references.

Safety margins consistent with good engineering practices.

Conclusions consistent with analytical results and applicable limits.

Results and conclusions address all points required in the problem statement.

Format consistent with applicable guides or other standards.

Review calculations, comments, and/or notes are attached.

Document approved (for example, the reviewer affirms the technical

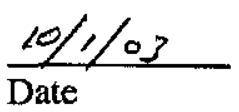

* All "no" responses must be explained below or on an additional sheet.

** Any calculations, comments, or notes generated as part of this review should be signed, dated and attached to this checklist. The material should be labeled and recorded in such a manner as to be understandable to a technically qualified third party. 


\title{
CHECKLIST FOR TECHNICAL PEER REVIEW
}

\author{
Document Reviewed - SNF-10272 Section 3.4 .13
}

Title: Uncontrolled Release of Argon

Author: D.A. Himes

Date: September 252003

\begin{tabular}{|c|c|c|}
\hline$\underline{\text { Yes }}$ & $\underline{\mathrm{No}^{*}}$ & NA \\
\hline$\left[\begin{array}{ll}{[} & ]\end{array}\right.$ & {$\left[\begin{array}{ll} & ]\end{array}\right.$} & {$[\sqrt{5}$} \\
\hline$[\sqrt{ }]$ & {$\left[\begin{array}{ll}{[} & ]\end{array}\right.$} & [ ] \\
\hline$[v]$ & {$\left[\begin{array}{ll}\text { [ } & \text { ] }\end{array}\right.$} & {[} \\
\hline$[\Omega$ & {$\left[\begin{array}{ll}{[} & ]\end{array}\right.$} & [ ] \\
\hline [ ] & [ ] & [x \\
\hline & [ ] & \\
\hline$\left[\begin{array}{ll}1 & 1\end{array}\right.$ & [ ] & {$[\mathcal{X}$} \\
\hline [ ] & {$\left[\begin{array}{ll}\text { ] } \\
\text { ] }\end{array}\right.$} & {$[x$} \\
\hline [ ] & {$\left[\begin{array}{ll}\text { l } & \text { ] }\end{array}\right.$} & {$[\mathscr{X}$} \\
\hline$\left[\begin{array}{ll}\text { ] } \\
\text { ] }\end{array}\right.$ & {$\left[\begin{array}{ll} & ]\end{array}\right.$} & \\
\hline [ ] & [ ] & \\
\hline$\left[\begin{array}{ll}{[} & ]\end{array}\right.$ & {$\left[\begin{array}{ll}\text { l } \\
\text { ] }\end{array}\right.$} & \\
\hline$\left[\begin{array}{ll}{[} & ]\end{array}\right.$ & {$\left[\begin{array}{ll}\text { l } & ]\end{array}\right.$} & \\
\hline [ & [ ] & [ ] \\
\hline$[J$ & {$\left[\begin{array}{ll}\text { [ } & \text { ] }\end{array}\right.$} & [ ] \\
\hline$[x$ & [ ] & \\
\hline [ ] & [ ] & [J \\
\hline [ ] & [ ] & {$[x$} \\
\hline$[\Delta]$ & [ ] & {$\left[\begin{array}{ll}\text { l } & \text { ] }\end{array}\right.$} \\
\hline
\end{tabular}

Referenced analyses appropriate.

Problem completely defined and all potential configurations considered. Accident scenarios developed in a clear and logical manner.

Necessary assumptions explicitly stated and supported.

Computer codes and data files documented.

Data used in calculations explicitly stated in document.

Data checked for consistency with original source information as applicable.

Mathematical derivations checked including dimensional consistency of results

Models appropriate and used within range of validity, or use outside range of established validity justified.

Hand calculations checked for errors. Spreadsheet results should be treated exactly the same as hand calculations.

Software input correct and consistent with document reviewed.

Software output consistent with input and with results reported in document reviewed.

Limits/criteria/guidelines applied to analysis results are appropriate and referenced. Limits/criteria/guidelines checked against references.

Safety margins consistent with good engineering practices.

Conclusions consistent with analytical results and applicable limits.

Results and conclusions address all points required in the problem statement.

Format consistent with applicable guides or other standards.

Review calculations, comments, and/or notes are attached.

Document approved (for example, the reviewer affirms the technical accuracy of the document).
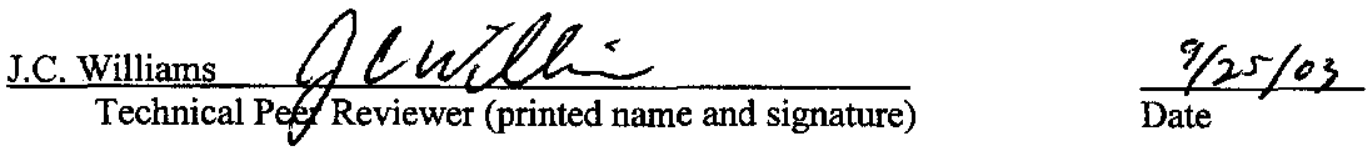

* All "no" responses must be explained below or on an additional sheet.

** Any calculations, comments, or notes generated as part of this review should be signed, dated and attached to this checklist. The material should be labeled and recorded in such a manner as to be understandable to a technically qualified third party. 
SNF-10272 REV. 2

This page is intentionally left blank. 